\title{
Navigation Study for Savannah Harbor Channel Improvements
}

Dennis Webb

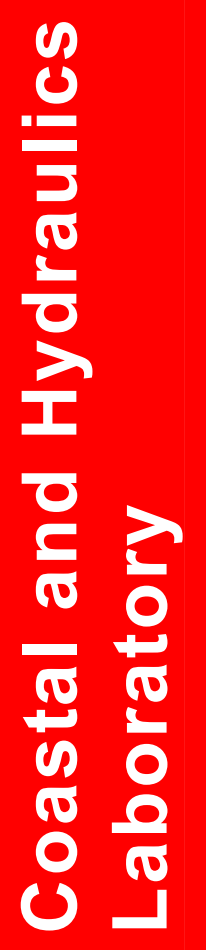




\title{
Navigation Study for Savannah Harbor Channel Improvements
}

\author{
Dennis Webb \\ Coastal and Hydraulics Laboratory \\ U.S. Army Engineer Research and Development Center \\ 3909 Halls Ferry Road \\ Vicksburg, MS 39180-6199
}

Final report

Approved for public release; distribution is unlimited.

Prepared for U.S. Army Engineer District, Savannah

PO Box 889

Savannah, GA 31402-0889 


\begin{abstract}
Savannah Harbor is located on the eastern shore of the state of Georgia. The harbor is being evaluated for deepening and widening. The purpose of the proposed improvements is to accommodate larger, deep-draft containerships to use the port. The widening is being considered to provide additional room for twoway traffic. To evaluate these improvements a real-time ship simulation study was undertaken. Simulation models were developed for both Savannah's present and future conditions. Pilots from Savannah Harbor operated the simulator as they would in real-life. Based upon these simulations, a final improved channel was developed.
\end{abstract}

DISCLAIMER: The contents of this report are not to be used for advertising, publication, or promotional purposes. Citation of trade names does not constitute an official endorsement or approval of the use of such commercial products. All product names and trademarks cited are the property of their respective owners. The findings of this report are not to be construed as an official Department of the Army position unless so designated by other authorized documents.

DESTROY THIS REPORT WHEN NO LONGER NEEDED. DO NOT RETURN IT TO THE ORIGINATOR. 


\section{Contents}

Preface vii

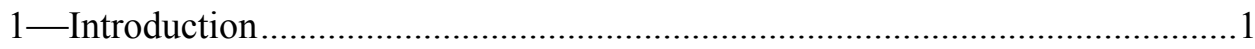

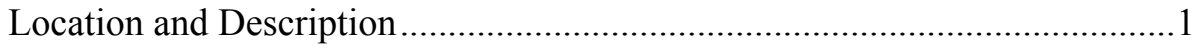

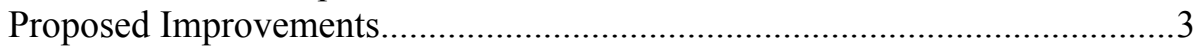

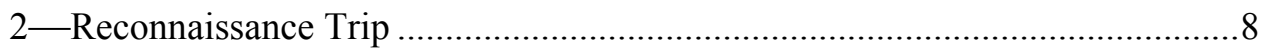

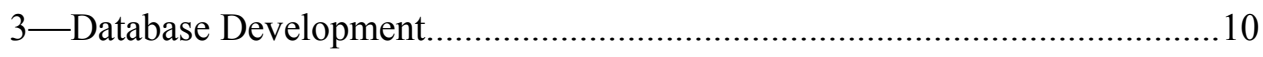

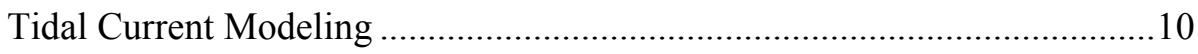

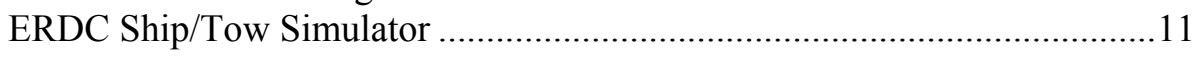

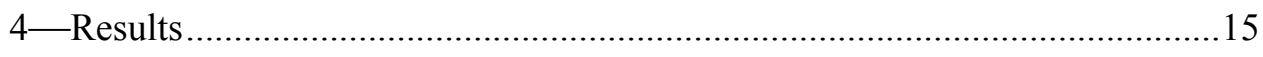

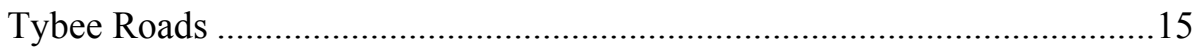

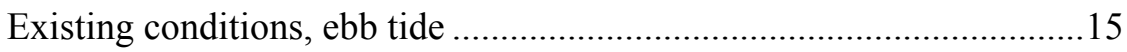

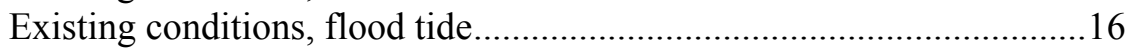

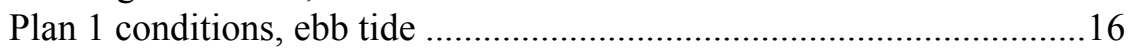

Plan 1 conditions, flood tide.................................................................17

Widener at turn between Tybee Range and Bloody Point Range ..........17

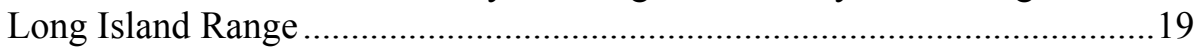

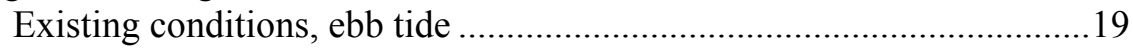

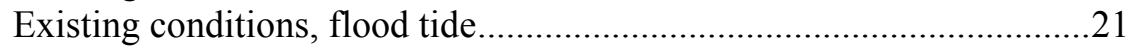

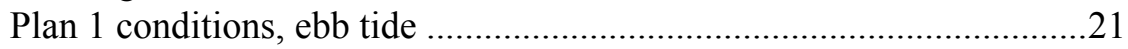

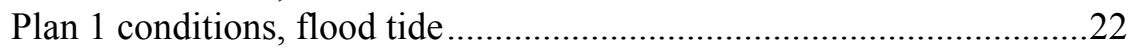

Plan 2 conditions, ebb tide ...............................................................23

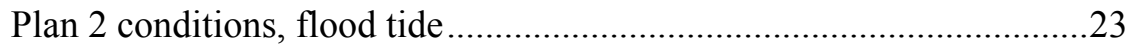

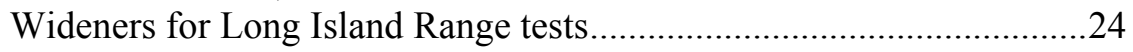

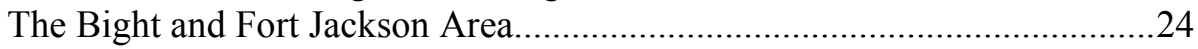

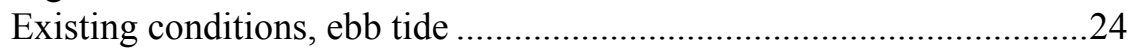

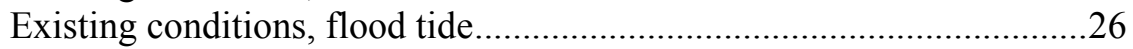

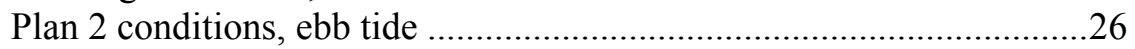

Plan 2 conditions, flood tide...........................................................27

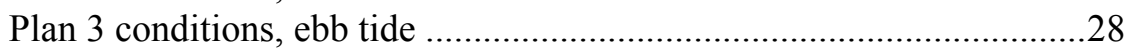

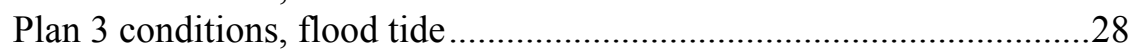

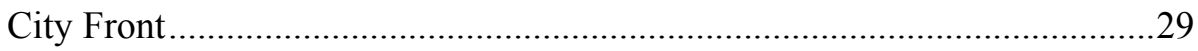

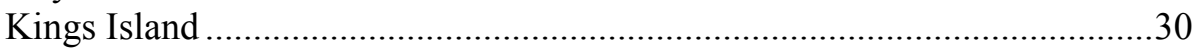

Additional Runs with 43-ft Draft Susan Maersk ...........................................30

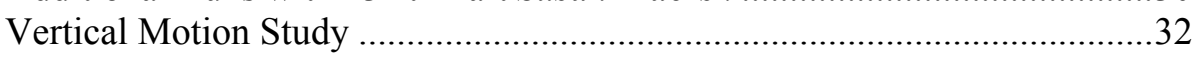


Plates 1-171

SF 298

\section{List of Figures}

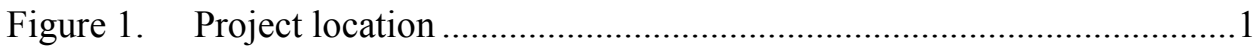

Figure 2. Channel deepened on existing side slopes ......................................

Figure 3. Existing and proposed channels, New Channel Range

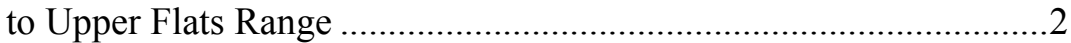

Figure 4. Existing and proposed channels, The Bight to City Front Channel....3

Figure 5. Existing and proposed channels, Tybee Range - Tybee Knoll

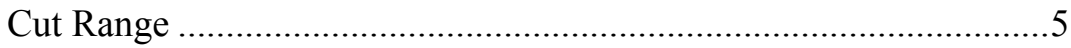

Figure 6. Pipeline requires shifting channel to east........................................5

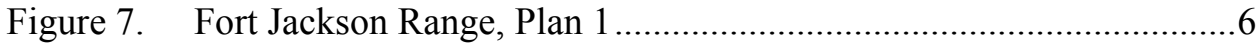

Figure 8. Fort Jackson Range, Plan 2 ..........................................................6

Figure 9. Existing and proposed channels, City Front to Kings Island

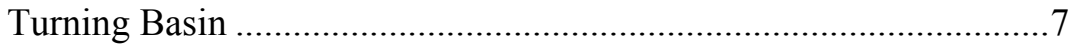

Figure 10. Camera setup on starboard wing, Ludwigshafen Express ..................9

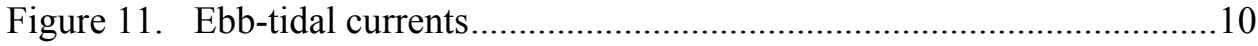

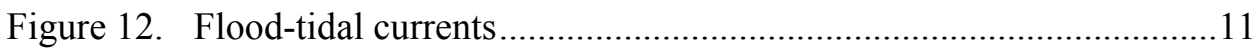

Figure 13. ERDC Ship/Tow Simulator, Savannah Harbor ...............................12

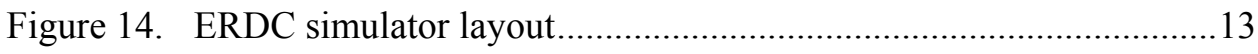

Figure 15. Arrangement of ERDC Ship/Tow bridge module............................14

Figure 16. Composite S-class runs on turn between Tybee Range and Bloody Point Range ............................................................. 18

Figure 17. Jones Island Range - all S-class runs ............................................. 18

Figure 18. Ownship view of inbound Susan Maersk .....................................20

Figure 19. Composite plot of all S-class runs through New Channel Range widener .25 
Figure 20. Composite plot of all S-class runs through Flats Range Area wideners

Figure 21. 43-ft draft Susan Maersk at turn between Tybee and Bloody Point Ranges

Figure 22. 43-ft draft Susan Maersk at Jones Island Range Turn ......................31

Figure 23. 43-ft Susan Maersk through Upper and Lower Flats Ranges ...........32

Figure 24. Recommended turn with tracks of all S-class containership simulations .36

Figure 25. Jones Island Range, all S-class containership tracks .......................37

Figure 26. Recommended widener for Jones Island Range .37

Figure 27. Channel recommendations Lower Flats Range through The Bight Channel .38

\section{List of Tables}

Table 1. Clearance for Susan Maersk Drafting $47.5 \mathrm{ft}$.................................34

Table 2. Clearance for Susan Maersk Drafting $46.0 \mathrm{ft}$.................................35 


\section{Conversion Factors, Non-SI to SI Units of Measurement}

Non-SI units of measurement used in this report can be converted to SI units as follows:

\begin{tabular}{|l|c|l||}
\hline Multiply & By & To Obtain \\
\hline \hline cubic feet & 0.02831685 & cubic meters \\
\hline degrees (angle) & 0.01745329 & radians \\
\hline feet & 0.3048 & meters \\
\hline miles (U.S. statute) & 1.609347 & kilometers \\
\hline square miles & $2,589,998$ & square meters \\
\hline
\end{tabular}




\section{Preface}

The model investigation described herein was conducted for the U.S. Army Corps of Engineer District, Savannah, by the U.S. Army Engineer Research and Development Center (ERDC), Vicksburg, MS. The simulator experiments were performed during the period of Sept 2003 to October 2003 by personnel of the Coastal and Hydraulics Laboratory (CHL), under the general supervision of $\mathrm{Mr}$. Thomas W. Richardson, Director, CHL; Dr. William D. Martin, Deputy Director, CHL; Mr. Donald. C. Wilson, Chief of Navigation Branch, CHL; and Dr. Sandra Knight, and Ms. Joan Pope, Technical Directors, CHL.

During the course of the model study, representatives of the Savannah District and other navigation interest visited ERDC at various times to observe the simulator and discuss tests results. The Savannah District was informed of the progress of the simulator study through monthly progress reports. The simulation models for the Susan Maersk and SL Performance were developed by Designers and Planners Inc.

The principal investigator in immediate charge of the navigation portion of the simulator study was Mr. Dennis Webb, assisted by Ms. Peggy Van Norman, and Ms Donna D. Derrick, all of the Navigation Branch, and Ms. Sally Harrison, contractor for Analytical Services, Inc. Mr. Webb prepared this report.

The Director of ERDC during publication of this report was Dr. James Houston. Colonel James Rowan, EN, was Commander and Executive Director. 


\section{Introduction}

\section{Location and Description}

Savannah Harbor is located on the eastern shore of the state of Georgia (Figure 1) and is presently $42 \mathrm{ft}$ deep. To accommodate larger, deeper drafted containerships, the U.S. Army Engineer District, Savannah, is evaluating channel designs to deepen much of the harbor to a depth not to exceed $48 \mathrm{ft}$. Nearly 30 miles of the existing $42-\mathrm{ft}$ project will be deepened as well as an extension in the Atlantic Ocean. The tidal range for Savannah Harbor is typically $8 \mathrm{ft}$.

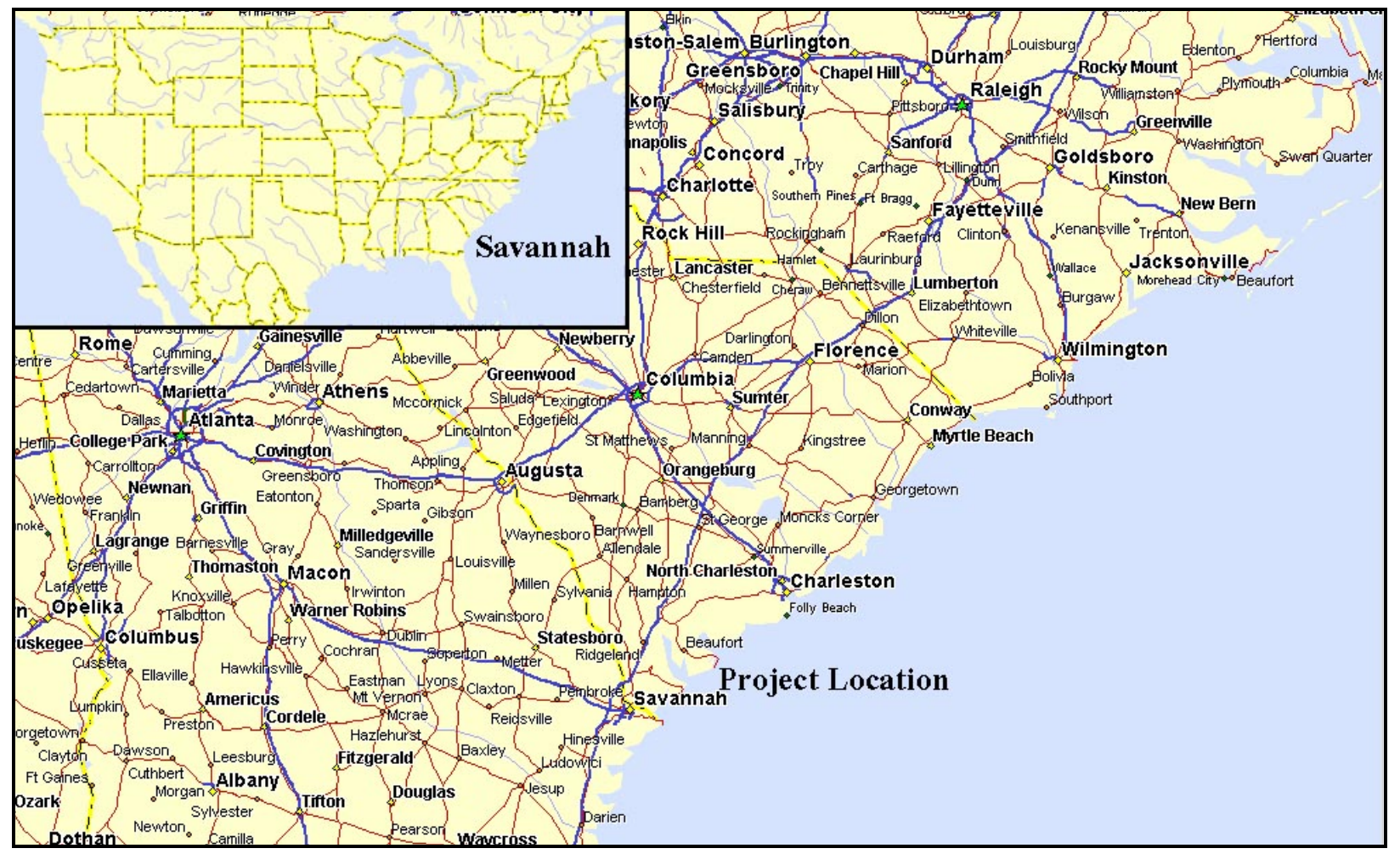

Figure 1. Project location 
Most of the deepening of Savannah Harbor is anticipated to be done on the existing side slopes (Figure 2). This will effectively reduce the bottom width of the navigation channel in most areas. However, the Savannah District proposes bend wideners in most channel turns. Also, a plan to widen the Long Island Crossing Range by $100 \mathrm{ft}$ on the south is being considered to provide additional room for two-way traffic (Figure 3). In addition, the Fort Jackson Reach (Figure 4) was realigned to avoid relocating pipelines.

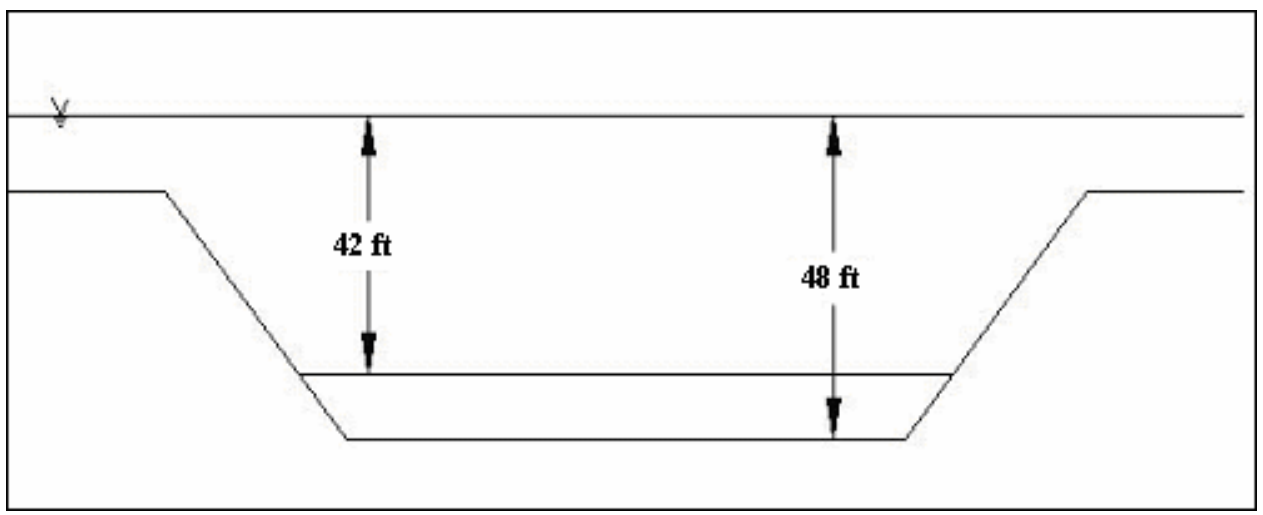

Figure 2. Channel deepened on existing side slopes

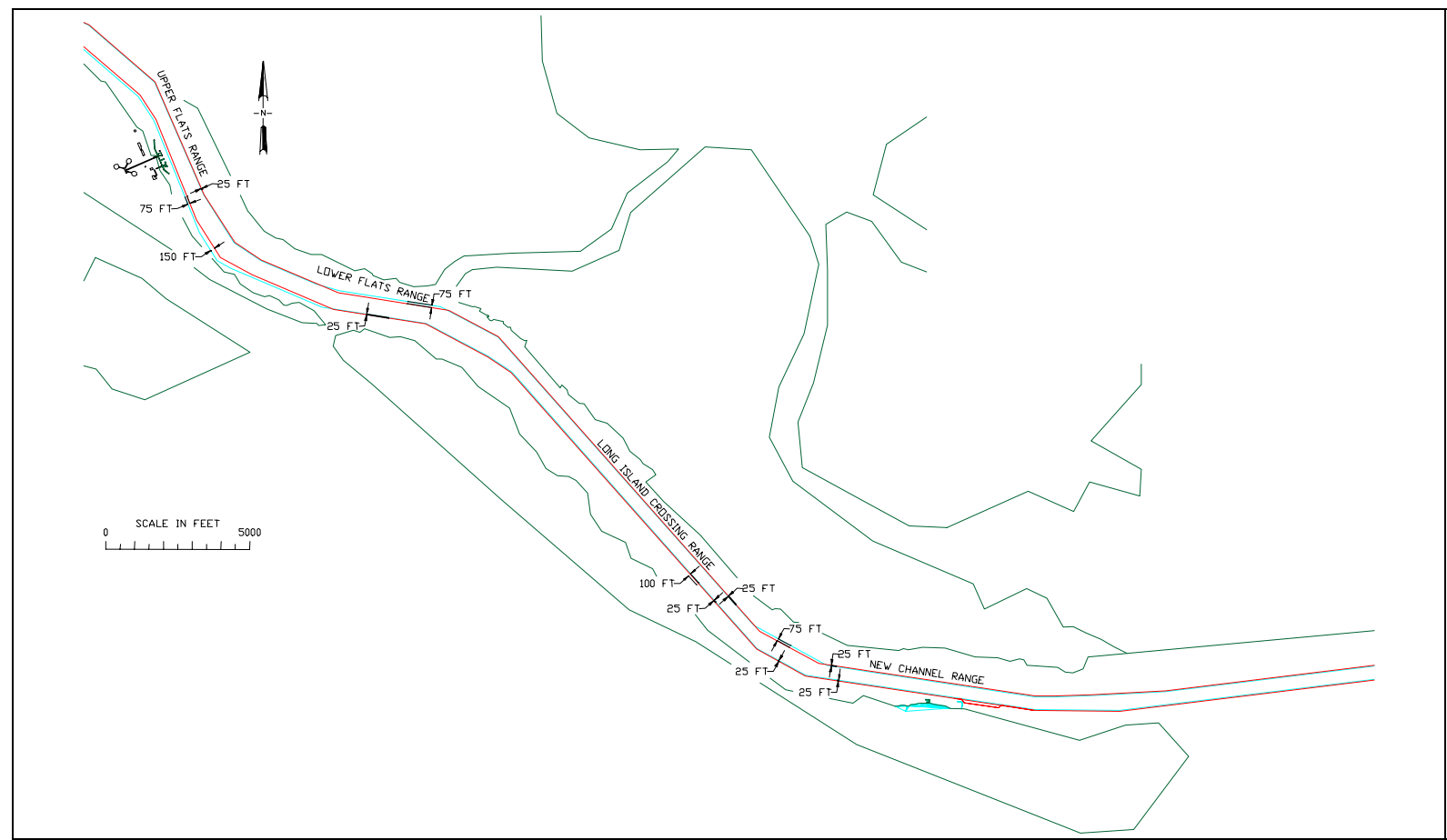

Figure 3. Existing and proposed channels, New Channel Range to Upper Flats Range 


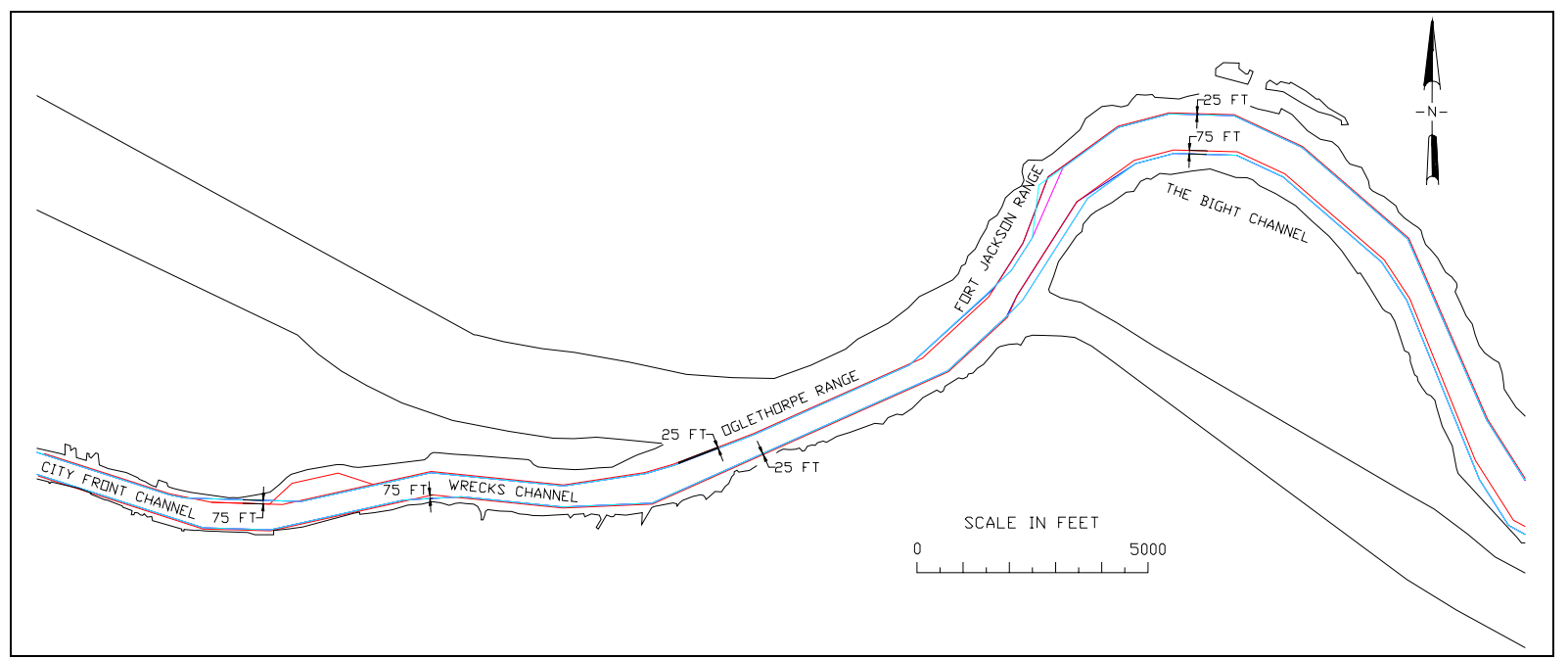

Figure 4. Existing and proposed channels, The Bight to City Front Channel

The U.S. Army Engineer Research and Development Center (ERDC) conducted a navigation study utilizing real-time ship simulation modeling to evaluate the proposed improvements to Savannah Harbor. Model development and on-line testing occurred at the ERDC Waterways Experiment Station (WES) in Vicksburg, MS, during the period from December 2001 to January 2003.

Two design ships were used for the study: one to represent existing vessel traffic and the other to represent future traffic. The design ship for the existing channel was the $S L$ Performance, a panamax containership loaded to $33 \mathrm{ft}$. The $S L$ Performance is $950 \mathrm{ft}$ long with a beam of $106 \mathrm{ft}$. The design ship for the proposed channel was the Susan Maersk. The Susan Maersk is a post-panamax S-class containership with a length of 1,140 ft and a beam of $144 \mathrm{ft}$. The Susan Maersk loaded to $47.5 \mathrm{ft}$.

\section{Proposed Improvements}

Most of the deepening of Savannah Harbor will be done on the existing side slopes (Figure 2), which will effectively reduce the bottom width of the navigation channel in most areas. However, the Savannah District proposes bend wideners in most channel turns.

The changes to the horizontal channel limits will be presented, beginning with the entrance channel and proceeding inland. Unless otherwise indicated, these changes are part of Plan 1.

The existing Tybee Range is $600 \mathrm{ft}$ wide. Deepening to $48 \mathrm{ft}$ on the existing side slopes will narrow the proposed channel to approximately $550 \mathrm{ft}$ (Figure 3). The west side of the turn onto Bloody Point Range is deepened on the existing side slope and thus the channel width is reduced by about $25 \mathrm{ft}$ on the west side. However, the Savannah District has proposed a $75 \mathrm{ft}$ widener on the east side of the turn. The Bloody Point Range is presently $600 \mathrm{ft}$ wide. The 25 - $\mathrm{ft}$ reduction 
on each side caused by deepening on the existing side slopes will narrow the channel to approximately $550 \mathrm{ft}$. The Jones Island Range, which is the turn from Bloody Point Range to Tybee Knoll Cut Range, was reduced by $25 \mathrm{ft}$ on the north side, but $t$ the Savannah District proposal widened the channel by $75 \mathrm{ft}$ on the south. Therefore, the width of Jones Island Range was increased from $700 \mathrm{ft}$ to $750 \mathrm{ft}$. Tybee Knoll Cut Range is presently $500 \mathrm{ft}$ wide. Deepening to $48 \mathrm{ft}$ on the existing side slopes reduced that width to $450 \mathrm{ft}$.

The New Channel Range (Figure 4) is $500 \mathrm{ft}$ wide. The proposed $48-\mathrm{ft}$ channel will narrow New Channel Range to $450 \mathrm{ft}$. The west side of the turn onto Long Island Crossing Range is deepened on the existing side slope and thus the channel width is reduced by about $25 \mathrm{ft}$ on the west side. However, SAS has proposed a $75 \mathrm{ft}$ widener on the east side of the turn. The Long Island Crossing Range is presently $500 \mathrm{ft}$ wide. There are two proposed widths for Long Island Crossing Range. Plan 1, deepened upon the existing side slopes, reduces the channel width to $450 \mathrm{ft}$. Plan 2, widens the western side of the Long Island Crossing Range deepened channel by $100 \mathrm{ft}$, thus increasing the channel width to $550 \mathrm{ft}$. Plans 1 and 2 were identical for the reaches immediately east and west of Long Island Crossing Range. The existing Lower Flats Range is $600 \mathrm{ft}$ wide. The proposed Plan 1 widened the north side of Lower Flats Range by $75 \mathrm{ft}$. The south side of Lower Flats Range was narrowed by $25 \mathrm{ft}$ due to deepening on the existing side slope. Therefore, the Plan 1 Lower Flats Range is $650 \mathrm{ft}$ wide. SAS has provided an additional $150 \mathrm{ft}$ on the west side of the turn between Lower Flats Range and Upper Flats Range. The east side of the turn was narrowed by $25 \mathrm{ft}$ due to deepening on the existing side slope. The Upper Flats Range is $550 \mathrm{ft}$ wide. The proposed Plan 1 Upper Flats Range was widened by $75 \mathrm{ft}$ on the west side. The east side of the proposed Plan 1 Upper Flats Range was narrowed by $25 \mathrm{ft}$ due to deepening on the existing side slope. Therefore, the Plan 1 Upper Flats Range was $600 \mathrm{ft}$ wide.

The Bight Channel is currently a series of $800 \mathrm{ft}$ wide segments as shown in Figure 5. The north side of Plan 1 Bight Channel was narrowed by $25 \mathrm{ft}$ due to deepening on the existing side slope. The south side of the Plan 1 Bight Channel was widened $75 \mathrm{ft}$. Thus, the Plan 1 Bight Channel is $850 \mathrm{ft}$ wide. The channel immediately west of The Bight Channel, the Fort Jackson Reach was realigned to avoid relocating pipelines (Figure 6). The first proposed alignment, Plan 1, shifted the channel to the east and provided a large triangular area for the ship's stern to swing when heading outbound (Figure 7). However, concern over inbound ships using the triangular area and then running aground because they were too far west lead to Plan 1 being abandoned and Plan 2 being developed. Plan 2 is shown in Figure 8 and removed the large triangular area. A third plan, Plan 3, was also developed. Plan 3 is not shown since it is the existing channel deepened to $48 \mathrm{ft}$. Plan 3 did not deepen on the existing side slopes, so its footprint is the same as the existing Fort Jackson Range. 


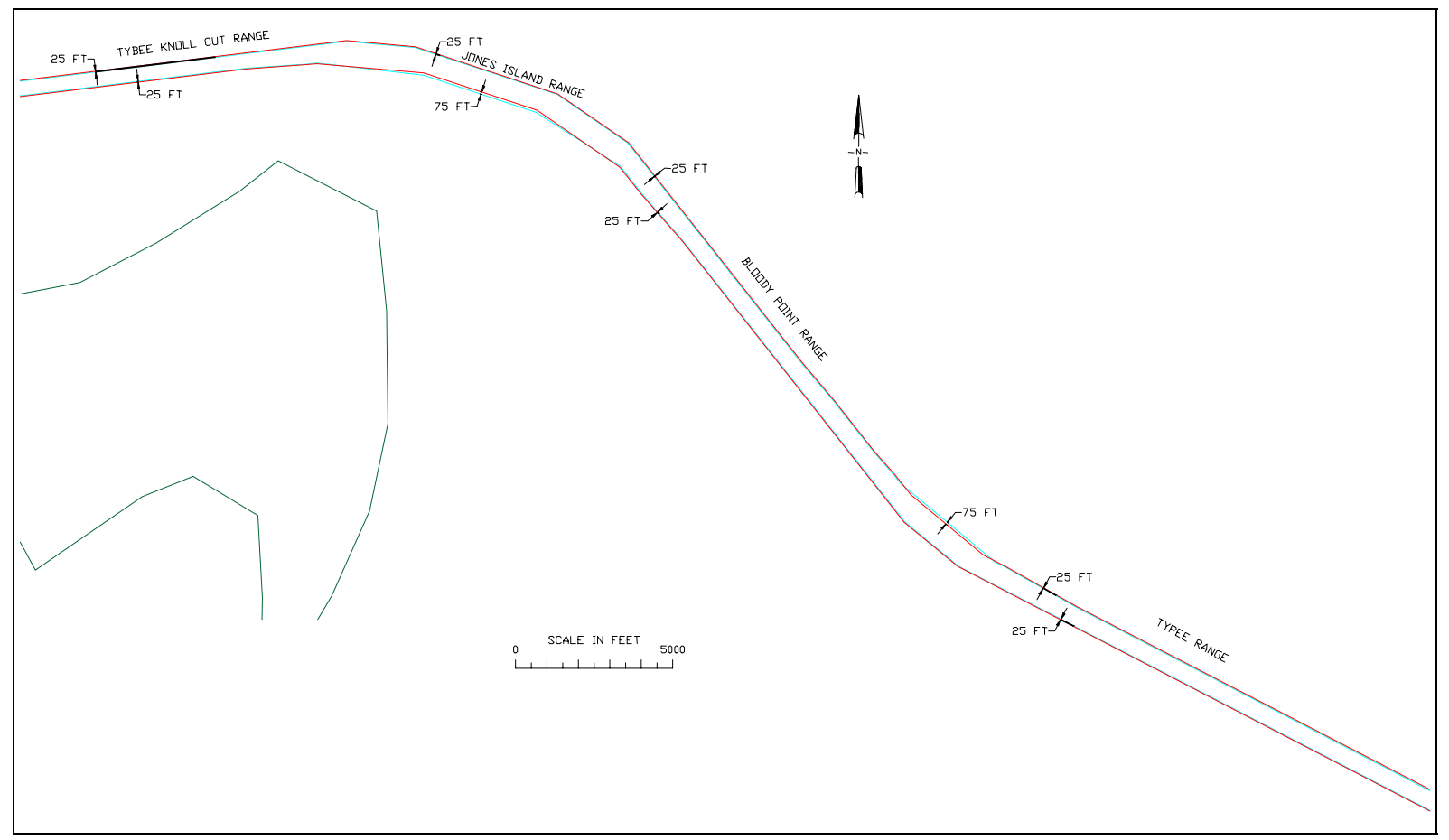

Figure 5. Existing and proposed channels, Tybee Range - Tybee Knoll Cut Range

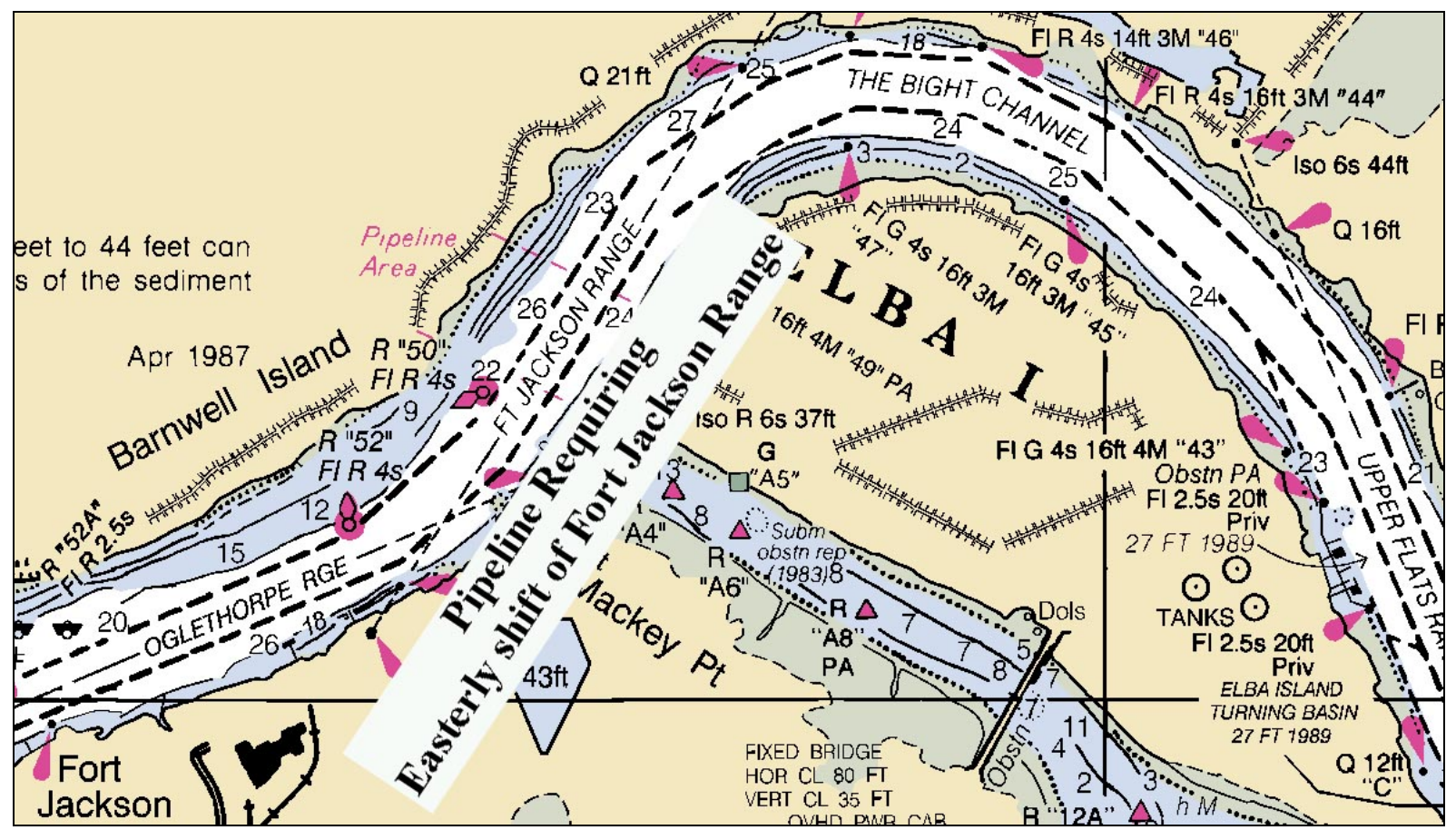

Figure 6. Pipeline requires shifting channel to east 


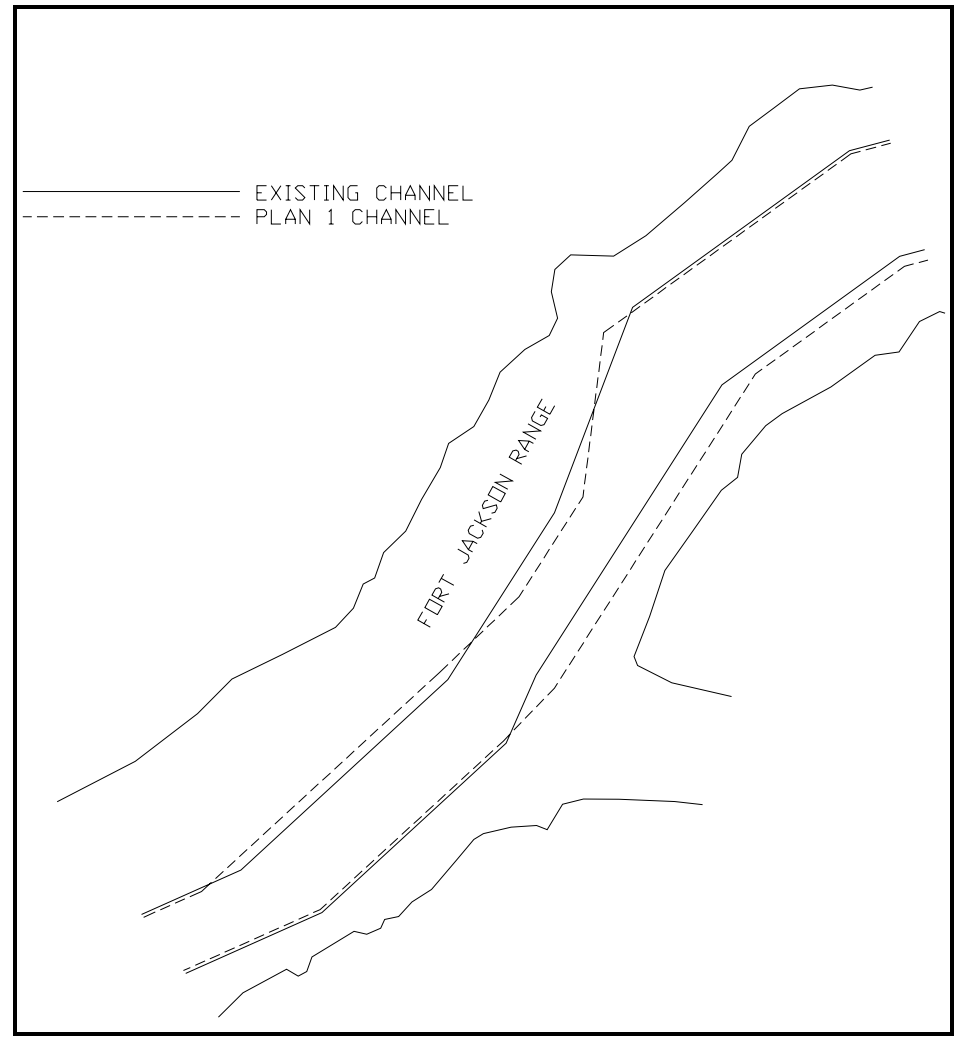

Figure 7. Fort Jackson Range, Plan 1

Figure 8. Fort Jackson Range, Plan 2

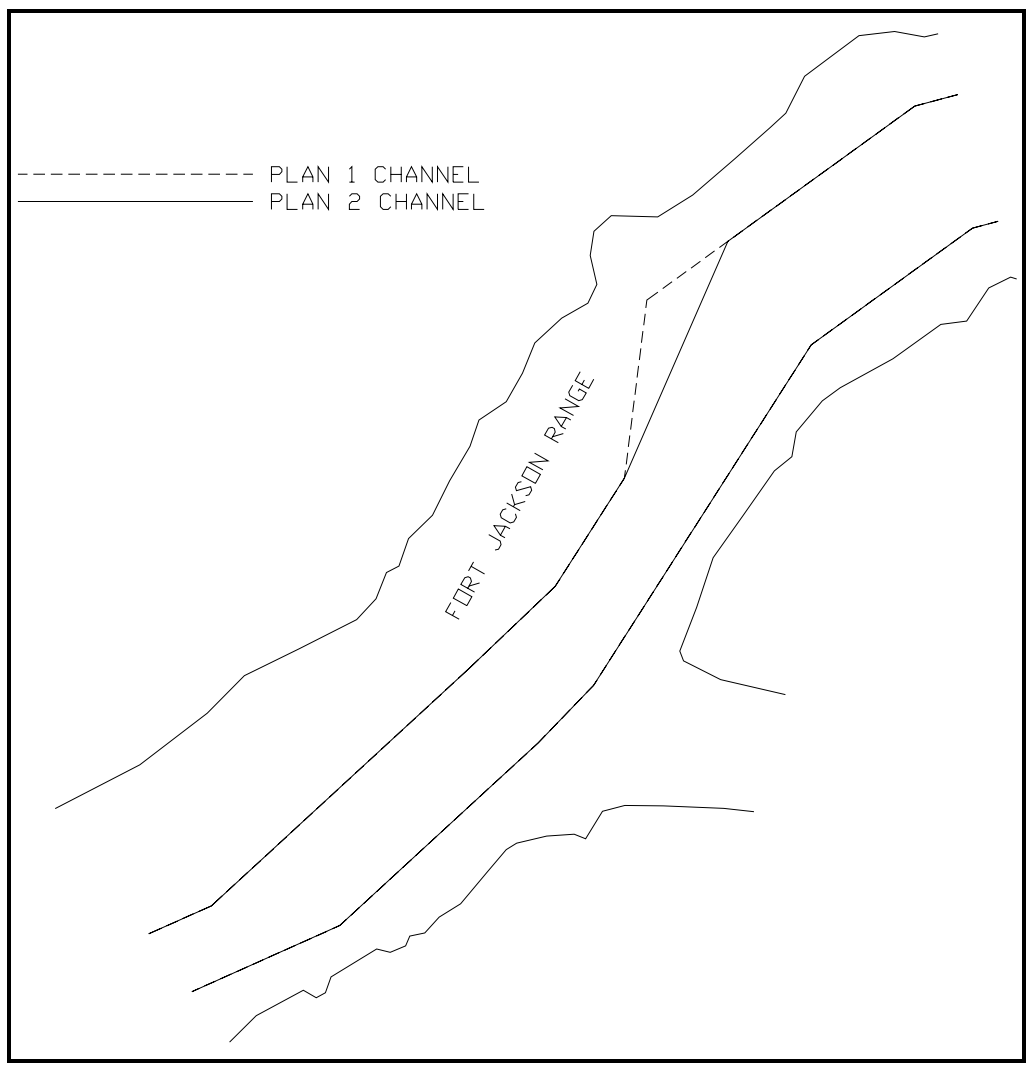


There was only one proposed deepening plan for Oglethorpe Range and the Wrecks Channel. Both plans deepened on the existing side slopes. This reduced the width of both deepened channels from 500 to $450 \mathrm{ft}$. A 75- $\mathrm{ft}$ widener was proposed for the turn at the western end of the Wrecks Channel. A second plan, Plan 2, was developed without the widener. The existing turn was deepened along its side slopes, thus reducing the south side of the turn by $25 \mathrm{ft}$. Plan 1 also widened the turn east of City Front Channel by $75 \mathrm{ft}$ on the north side.

The turn between City Front Channel and Marsh Island Channel was widened by $75 \mathrm{ft}$ as part of Plan 1 (Figure 9). The remainder of March Island Channel was deepened on the existing side slopes, thus reducing the channel width from 500 to $450 \mathrm{ft}$. Plan 1 widens the turn between Marsh Island Channel and Kings Island Channel by $75 \mathrm{ft}$ on the north side. The remainder of Kings Island Channel was deepened on the existing side slopes, thus reducing the channel width from 500 to $450 \mathrm{ft}$. The north side of Kings Island Turning Basin was widened by $75 \mathrm{ft}$. The rest of the basin was reduced by $25 \mathrm{ft}$ by deepening along the existing side slopes.

Figure 9. Existing and proposed channels, City Front to Kings Island Turning Basin

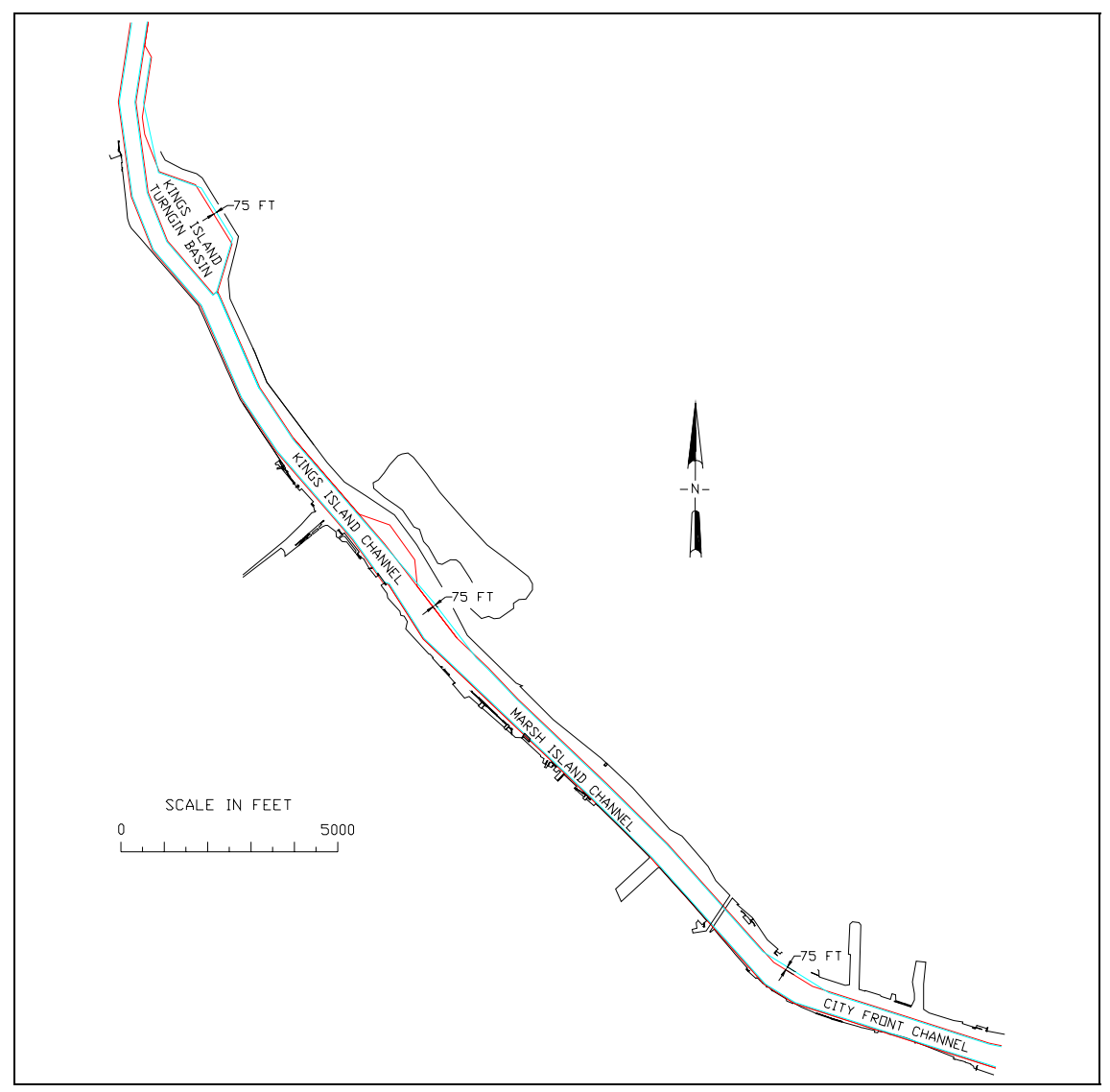




\section{Reconnaissance Trip}

The reconnaissance trip for Savannah Harbor was undertaken December 3-5, 2001. The purpose of the reconnaissance trip was to observe navigation conditions in the Savannah River. The project site was photographed to update the simulation visual scene.

On December 3, representatives of the Savannah District and ERDC boarded the Ludwigshafen Express at approximately 0800, and were by accompanied Capt. Spencer Edleman of the Savannah pilots Association. The Ludwigshafen Express (Capt. Martin Huls) is a Panamax containership, $965 \mathrm{ft}$ length overall with a beam of $105 \mathrm{ft}$. The ship's draft was $35 \mathrm{ft}$. The transit was conducted at high water, estimated to be $+9 \mathrm{ft}$ by Capt. Edleman. Typically, high water is $+8 \mathrm{ft}$. Two digital video cameras were mounted on the starboard wing. One looked over the bow and the other perpendicular to the ship (Figure 10). One digital video camera was mounted on the port wing, looking perpendicular to the ship. Additional still digital photos were taken throughout the transit. A handheld Global Positioning System (GPS) unit was placed on the starboard wing to track the ship's progress though the channel.

During the transit, Capt. Edleman provided insight to navigation conditions on the Savannah River as follows:

a. Wind-driven currents occur in the Atlantic, typically with a wind from the south/southwest and combined with flood tide. The crosscurrents occur in the two easternmost channel segments.

$b$. The currents are usually aligned with the channel in the protected portions of the river.

c. It would be helpful to widen the Long Island Crossing Range by $100 \mathrm{ft}$ on the south to provide additional room for meeting.

d. Ships are restricted to 4-ft underkeel clearance in the entrance and 2-ft underkeel clearance inside.

e. A new liquified natural gas (LNG) facility and turning basin are under construction along the south side of Upper Flats Range. The turning basin is not part of the channel improvements being evaluated by this study. Ships will not meet near the facility when an LNG tanker is docked.

f. Two-way traffic occurs over most of the project. Pilots try to time their meetings for the straight reaches. 


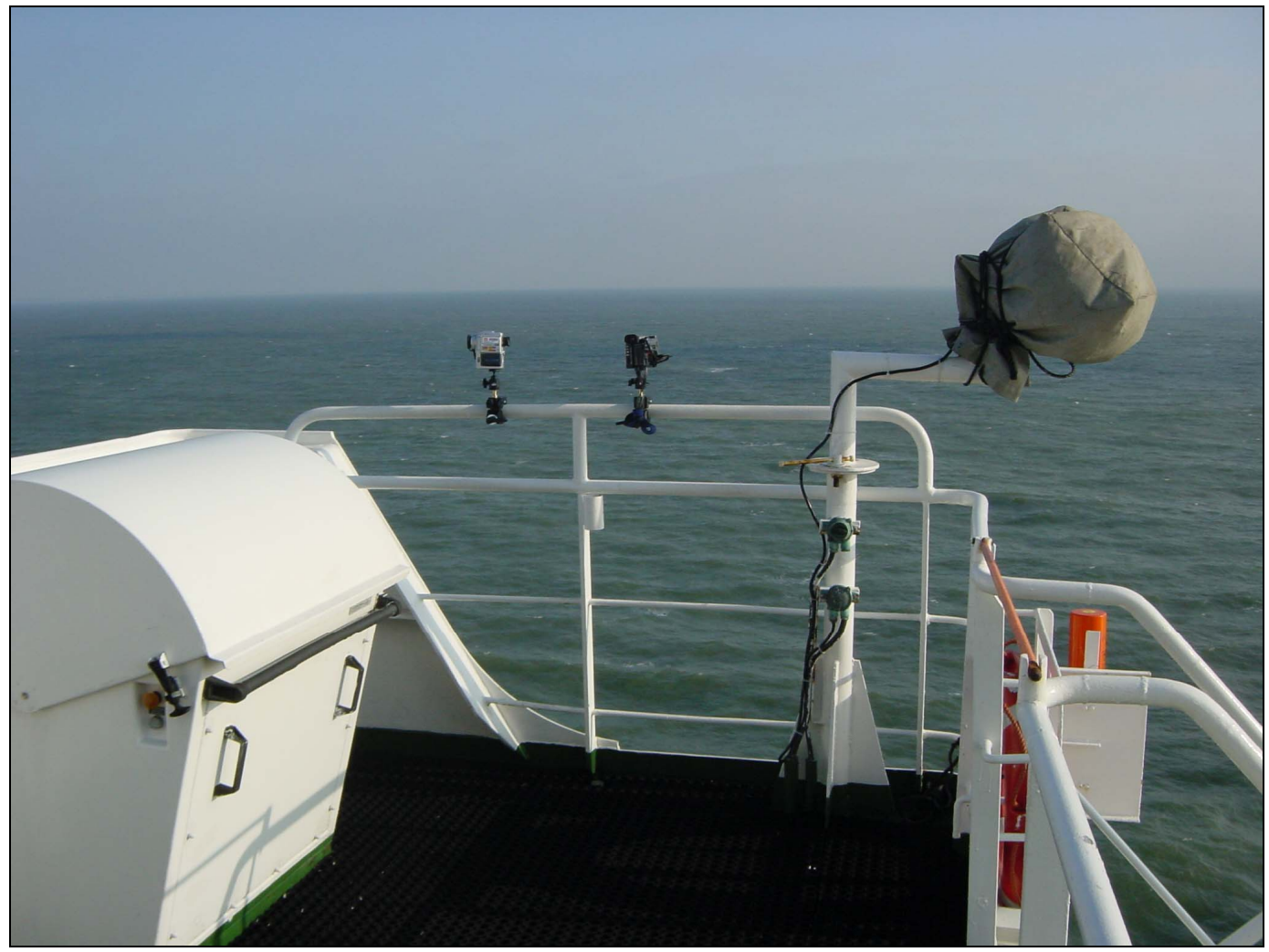

Figure 10. Camera setup on starboard wing, Ludwigshafen Express

Transit continued to the King's Island Turning Basin. The ship was turned and docked at container terminal No. 3. The representatives departed the ship about 1245 .

On December 5, the representatives boarded thePanamex containership Hanjin Tokyo at 0700. The draft of the Hanjin Tokyo was $34 \mathrm{ft}$. The pilot was Capt. Sam Meyer. Low water occurred at 0500, $2 \mathrm{hr}$ into the flood-tidal cycle. Capt. Meyer noted two areas (inside the jetties and near Fort Jackson) where the ships were affected by currents. Currents ebbing from the Back River can affect ships near Fort Jackson. Capt. Meyer also noted that ebb-tidal currents work against inbound ships when making the turn from the Bight Channel to Fort Jackson Channel. The ship docked at a container berth near the southern end of the King's Island Turning Basin. The ship was not turned. It was docked port side to the dock. 


\section{Database Development}

\section{Tidal Current Modeling}

Currents for the proposed $48 \mathrm{ft}$ channel were calculated at ERDC with TABSMD study. Simulations were conducted for maximum ebb- and flood-tidal currents. The currents used to develop the simulation models of existing conditions are shown in Figures 11 and 12.

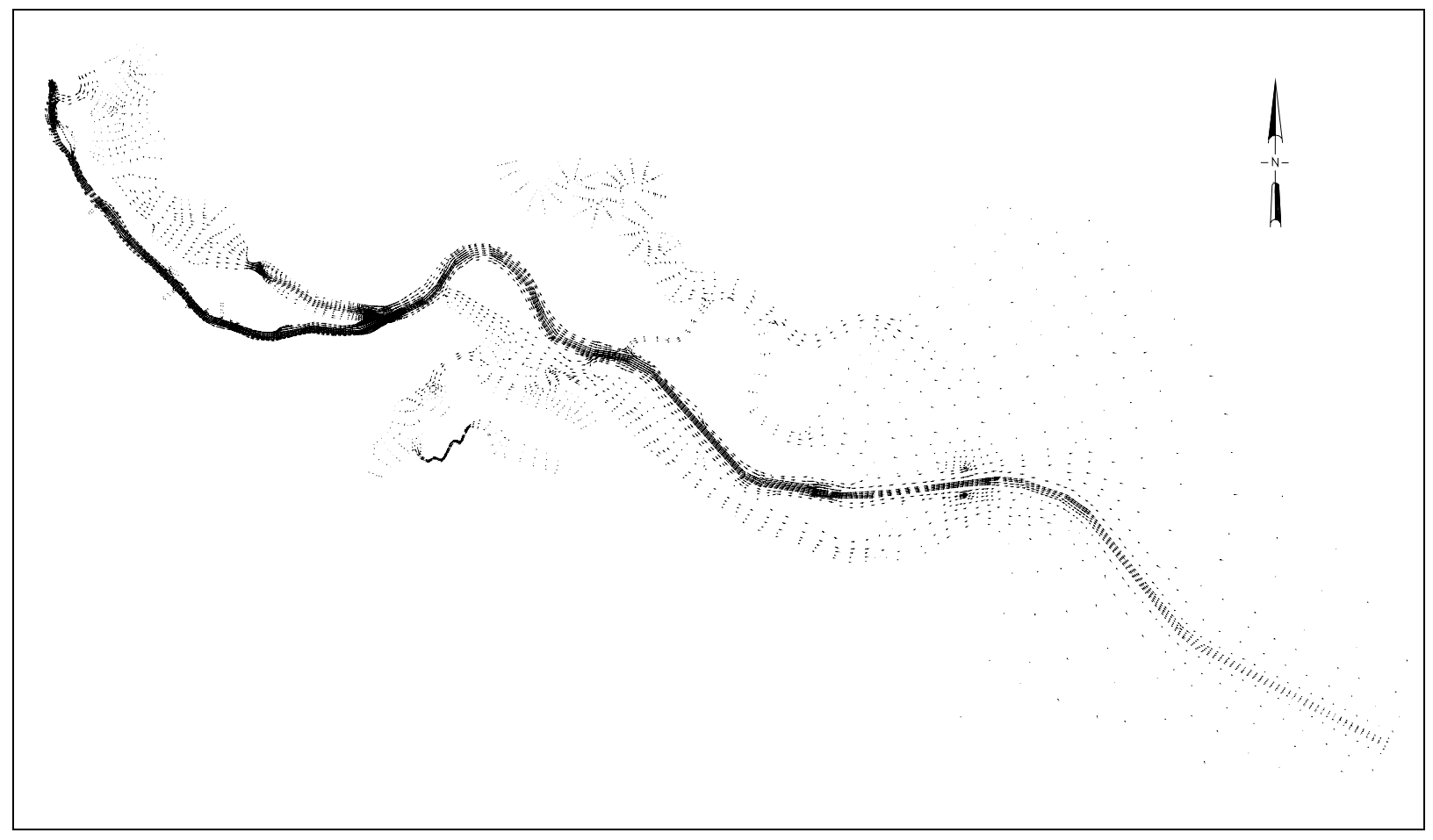

Figure 11. Ebb-tidal currents 


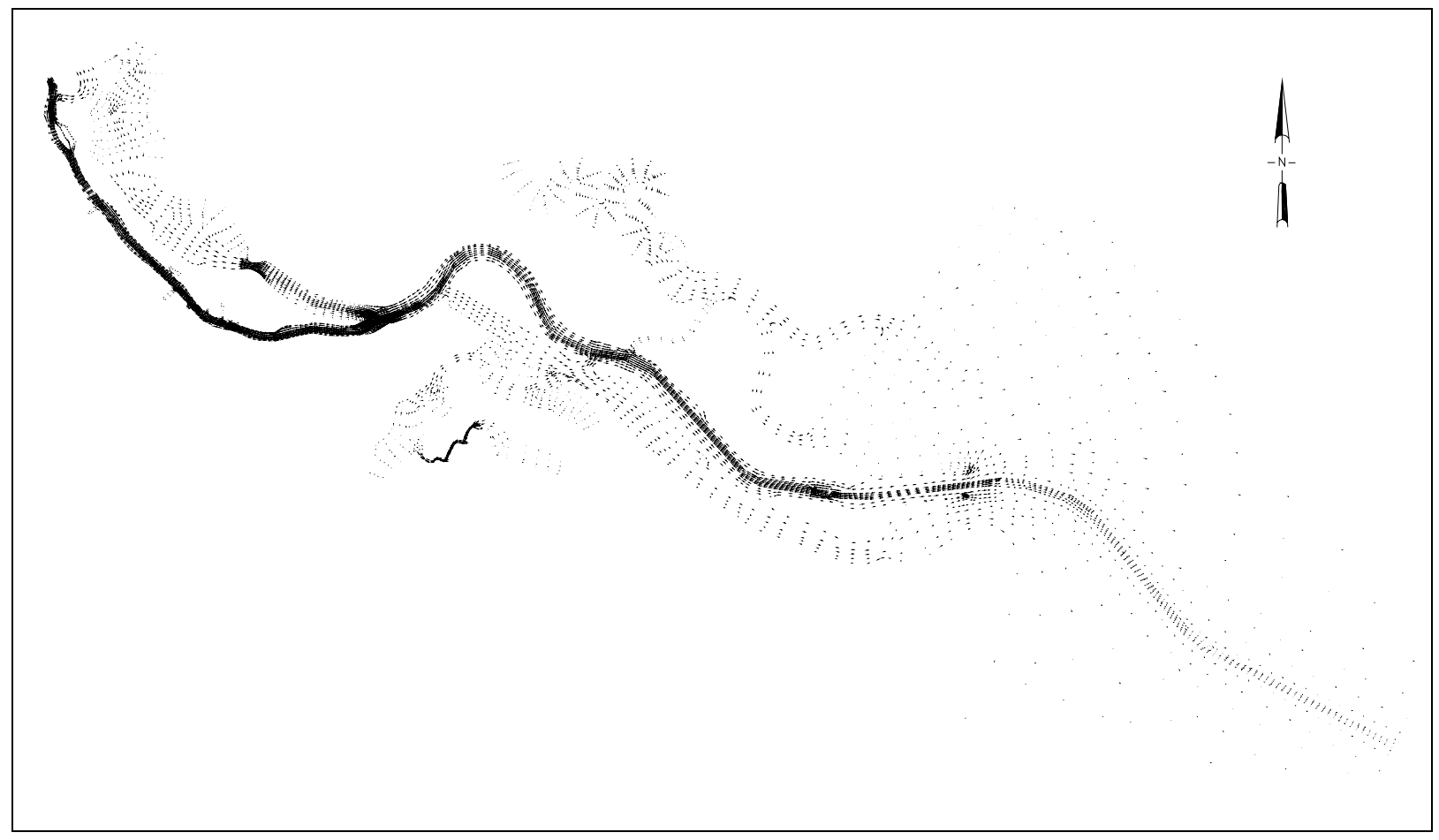

Figure 12. Flood-tidal currents

Currents were also modeled for two deepened conditions.

Wave conditions for the approach to Savannah Harbor were modeled in a separate study at ERDC (Thompson, in preparation). ${ }^{1}$

\section{ERDC Ship/Tow Simulator}

The new ERDC Ship/Tow Simulators have been operational since February 2002. The simulators are Computer Sciences Corp. (CSC) Virtual Ship 2000 models. The simulators are real-time, i.e. ship movements on the simulator require the same amount of time as in real life. Environmental forces such as currents, wind, banks, ship-ship interactions all act upon the vessel during a transit. The pilot cons the simulated vessel's engine speed and rudder. The pilot also has radio contact with assist tugs. The Susan Maersk has bow and stern thrusters that are pilot controlled. The two simulators were coupled together for two-way traffic. Figure 13 shows the ERDC simulator being operated during the Savannah study.

\footnotetext{
${ }^{1}$ Thompson, E. (in preparation). "Wave modeling navigation study for Savannah Harbor,
} Georgia,” U.S. Army Engineer Research and Development Center, Vicksburg, MS. 


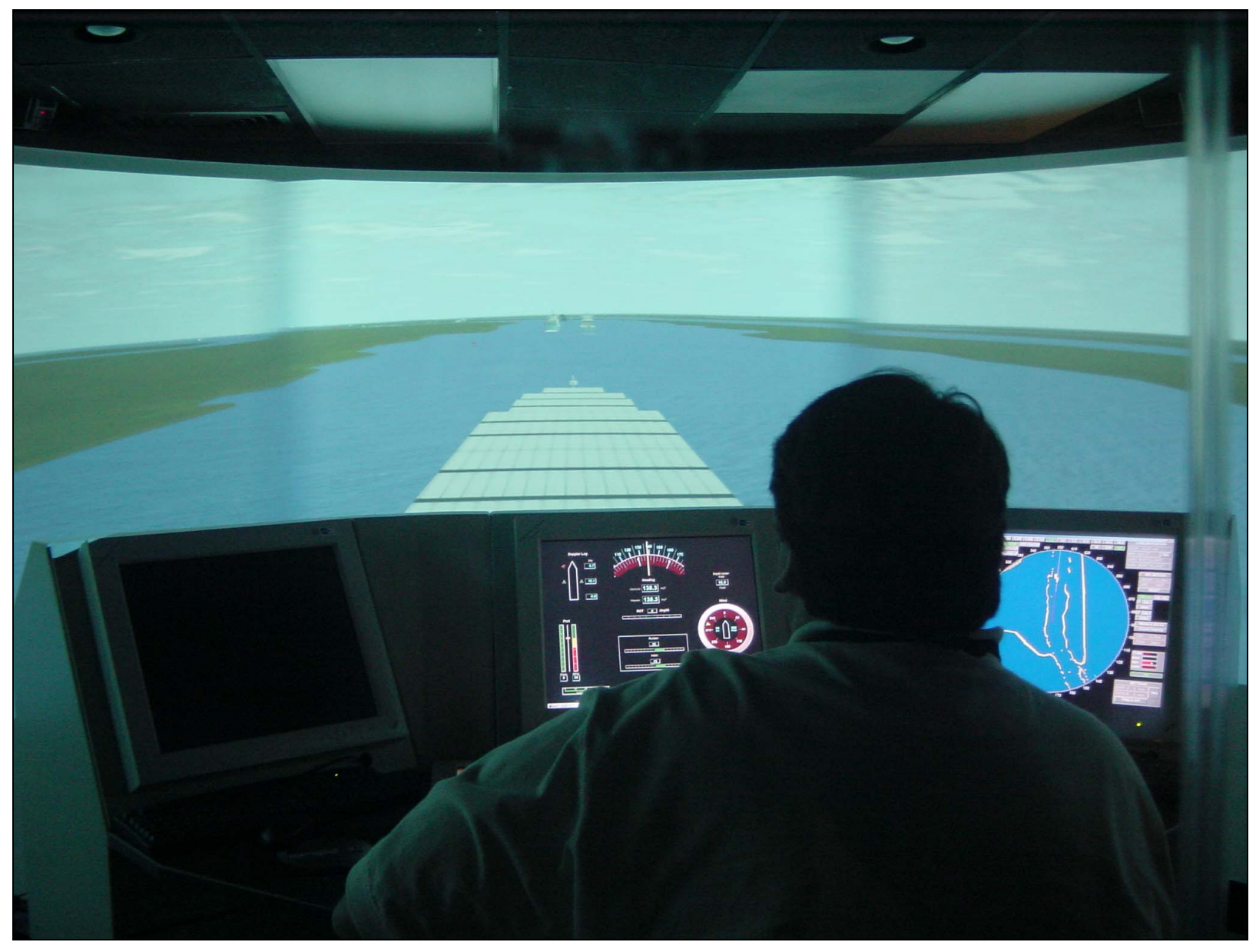

Figure 13. ERDC Ship/Tow Simulator, Savannah Harbor

A plan of the ERDC simulator facility is shown in Figure 14. The facility consists of two bridge modules, a viewing area, a pilot debriefing room and an operator station. A description of a bridge module is shown in Figure 15. 


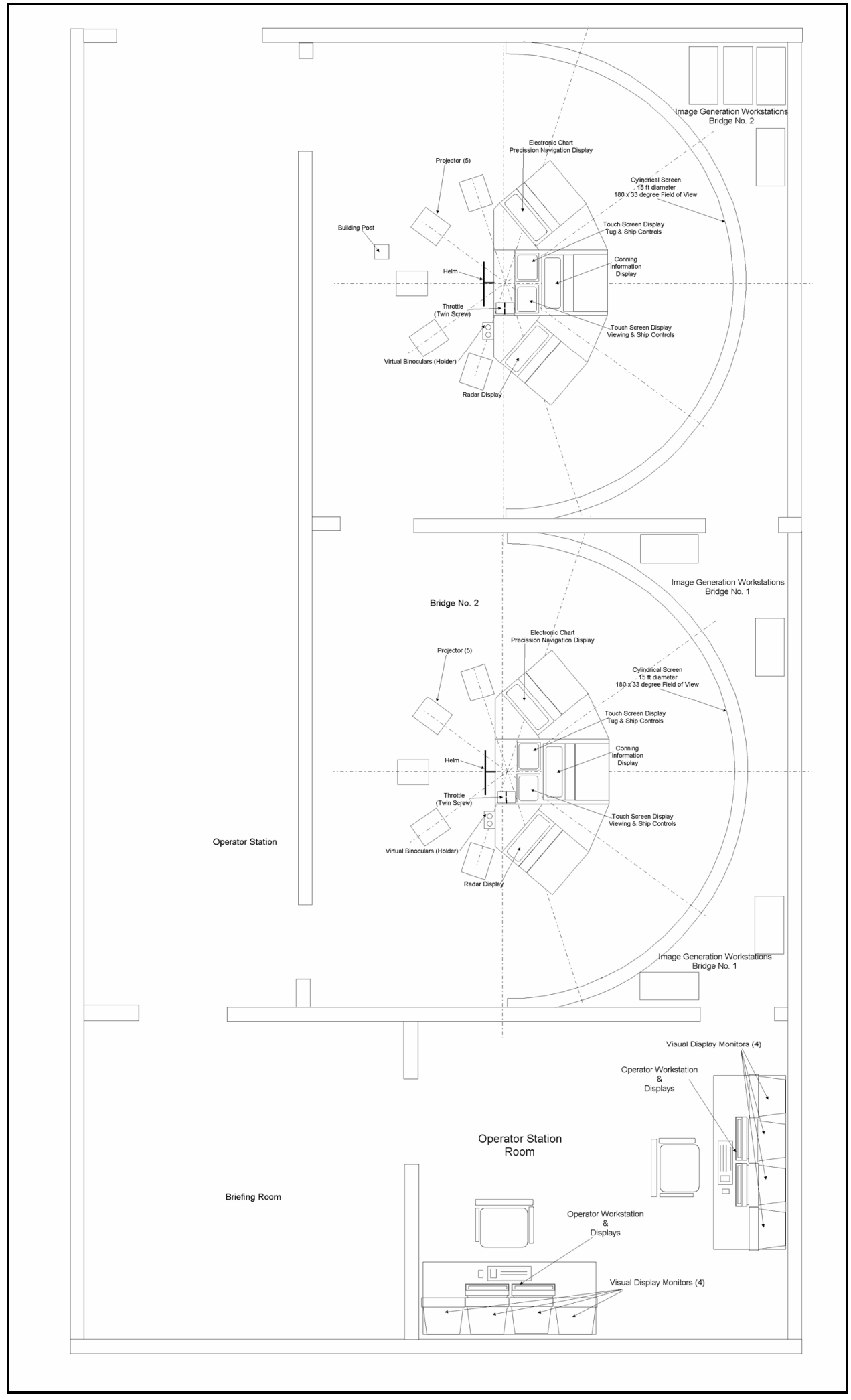

Figure 14. ERDC simulator layout 


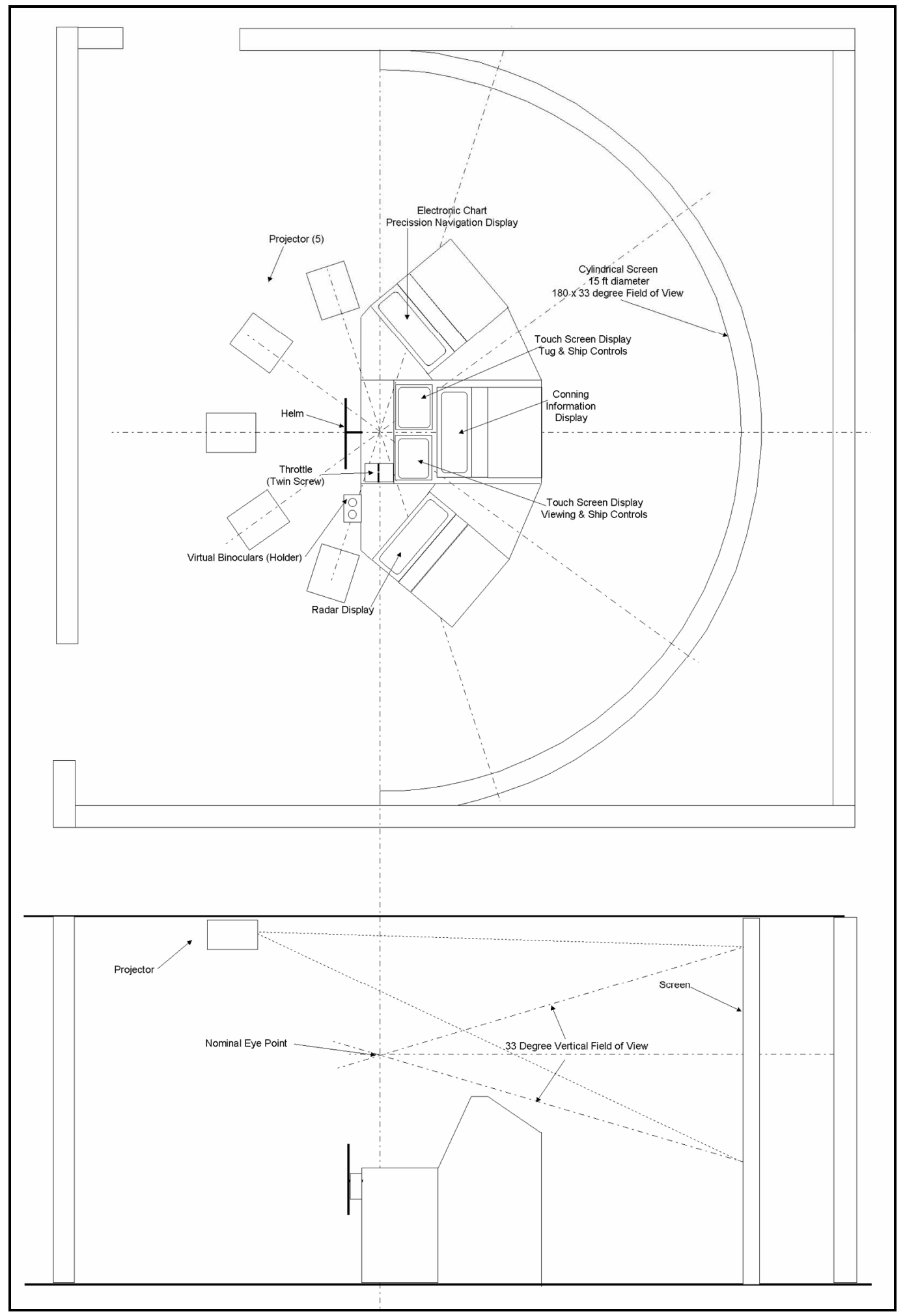

Figure 15. Arrangement of ERDC Ship/Tow bridge module 


\section{Results}

\section{Tybee Roads}

The results for the Tybee Roads simulations are presented in Plates 1-28. Two channel layouts were simulated, existing and Plan 1 . There was only one proposed channel configuration tested in this area. Both the existing and Plan 1 channels were simulated for two-way traffic operating in both ebb- and floodtidal currents. The simulations' starting positions were adjusted so that the meeting occurred on Bloody Point Range. The design ship for the existing channel was the SL Performance loaded to $33 \mathrm{ft}$. The design ship for the Plan 1 channel was the Susan Maersk, loaded to $47.5 \mathrm{ft}$.

The track plots for each simulation are presented on two plates to allow plotting at a readable scale. The western area is presented first, followed by the eastern area. Both the western and eastern plates are plotted to the same scale.

\section{Existing conditions, ebb tide}

The track plots for existing conditions, ebb tide, with pilot 1 inbound and pilot 2 outbound are shown in Plates 1 and 2. The two ships met on Bloody Point Range, between buoys 10 and 12. The ships were about $250 \mathrm{ft}$ apart when they met. The inbound ship crossed the channel line by about $10 \mathrm{ft}$ during meeting. Both the inbound and outbound ships left the Jones Island Range. The inbound ship went completely out of the channel while making the turn near buoy 14 . The outbound ship waited a little too late to begin turning to starboard near buoy 15 and left the channel by approximately $90 \mathrm{ft}$.

The track plots for existing conditions, ebb tide, with pilot 3 inbound and pilot 4 outbound are shown in Plates 3 and 4 . The two ships met on Bloody Point Range, between buoys 10 and 12, but closer to buoy 12. The ships were about $230 \mathrm{ft}$ apart while meeting and the inbound ship was about $5 \mathrm{ft}$ out of the channel. Both ships went entirely out of the channel near buoy 14, while turning between Jones Island Range and Bloody Point Range.

The track plots for existing conditions, ebb tide, with pilot 4 inbound and pilot 3 outbound are shown in Plates 5 and 6 . The two ships met on Bloody Point Range, between buoys 10 and 12. The ships were about $290 \mathrm{ft}$ apart when 
they met, with neither ship leaving the channel. The outbound ship left the channel by approximately $50 \mathrm{ft}$ near buoy 18 and by about $5 \mathrm{ft}$ near buoy 14 .

\section{Existing conditions, flood tide}

The track plots for existing conditions, flood tide, with pilot 1 inbound and pilot 2 outbound are shown in Plates 7 and 8 . The two ships met on Bloody Point Range, midway between buoys 10 and 12. Neither ship left the channel. The inbound ship left the channel on the north side near buoy 14. The ships were approximately $180 \mathrm{ft}$ apart when they met.

The track plots for existing conditions, flood tide, with pilot 3 inbound and pilot 4 outbound are shown in Plates 9 and 10. The two ships met on Bloody Point Range, midway between buoys 10 and 12 . The ships were extremely far apart at the meeting point, nearly $290 \mathrm{ft}$. Both ships crossed out of the channel limits by about $10 \mathrm{ft}$. Both ships left the channel near buoy 14. The inbound ship left by about $25 \mathrm{ft}$ and the outbound by nearly $55 \mathrm{ft}$. The inbound ship just crossed over the north side of the channel, west of buoy 18, when the exercise was ended.

The track plots for existing conditions, flood tide, with pilot 4 inbound and pilot 3 outbound are shown in Plates 11 and 12. The two ships met on Bloody Point Range, midway between buoys 10 and 12 . The ships were nearly $410 \mathrm{ft}$ apart, but the inbound ship went entirely out of the channel. The inbound ship also went entirely out of the channel between buoys 14 and 18 and nearly $80 \mathrm{ft}$ out of the channel west of buoy 18 .

\section{Plan 1 conditions, ebb tide}

The track plots for proposed conditions, ebb tide, with pilot 1 inbound and pilot 2 outbound are shown in Plates 13 and 14. The two ships met on Bloody Point Range, between buoys 10 and 12 . The ships were about $150 \mathrm{ft}$ apart when they met, with the inbound ship crossing the channel line by less than $25 \mathrm{ft}$. The inbound ship touched the northern channel edge near buoy 14. That was the only incident of a ship leaving the channel in the Jones Island Range area.

The track plots for proposed conditions, ebb tide, with pilot 2 inbound and pilot 1 outbound are shown in Plates 15 and 16. The two ships met between gated buoys 11 and 12 . The ships were about $70 \mathrm{ft}$ apart when they met and neither ship left the channel. Both the inbound and outbound ship came to the channel's edge near buoy 14, but neither left the channel. The outbound ship left the channel by about $25 \mathrm{ft}$ while entering the Jones Island Range near buoy 18 .

The track plots for proposed conditions, ebb tide, with pilot 3 inbound and pilot 4 outbound are shown in Plates 17 and 18. The two ships met on Bloody Point Range, between buoys 10 and 12 . The ships were approximately $150 \mathrm{ft}$ apart and neither left the channel. The inbound ship left the channel by nearly 70 $\mathrm{ft}$ near buoy 14. The outbound ship crossed the channel line by about $10 \mathrm{ft}$ at the same point as the inbound ship. The inbound ship crossed the channel limits by $10 \mathrm{ft}$ at buoy 18 . 
The track plots for proposed conditions, ebb tide, with pilot 4 inbound and pilot 3 outbound are shown in Plates 19 and 20. The two ships met on Bloody Point Range, between buoys 10 and 12. Both ships were further east than usual when they met. The two ships were about $100 \mathrm{ft}$ apart and this forced the inbound ship nearly $50 \mathrm{ft}$ out of the channel. The inbound ship left the channel near buoy 14 by approximately $90 \mathrm{ft}$. The outbound ship did not leave the channel at this point. However, the outbound ship did leave the channel by nearly 50 ftat buoy 18 .

\section{Plan 1 conditions, flood tide}

The track plots for proposed conditions, flood tide, with pilot 1 inbound and pilot 2 outbound are shown in Plates 21 and 22. The two ships met on Bloody Point Range, between buoys 10 and 12. The two ships were about $120 \mathrm{ft}$ apart at meeting. Although the inbound ship was close to the eastern channel edge, neither ship left the channel while meeting. The outbound ship did not leave the channel at any time during the run, and the inbound ship left the channel by about $60 \mathrm{ft}$ at buoy 14 .

The track plots for proposed conditions, flood tide, with pilot 2 inbound and pilot 1 outbound are shown in Plates 23 and 24. The two ships met on Bloody Point Range, between buoys 10 and 12, closer to gated buoys 11 and 12. The ships were about $110 \mathrm{ft}$ apart at the meeting. The inbound ship barely crossed the channel line by approximately $2 \mathrm{ft}$. The outbound ship left the channel by nearly $80 \mathrm{ft}$ at buoy 14 . The inbound ship stayed well within the channel at that point. Neither ship left the channel near buoy 18. The outbound ship came within $15 \mathrm{ft}$ of the channel's edge at buoy 18 .

The track plots for proposed conditions, flood tide, with pilot 3 inbound and pilot 4 outbound are shown in Plates 25 and 26. The two ships met between gated buoys 11 and 12. The two ships were about $110 \mathrm{ft}$ apart, and neither ship left the channel. The inbound ship entirely left the channel on Jones Island Range, between buoys 14 and 18. The inbound ship came near the northern channel edge on the eastern end of Tybee Knoll Cut Range, but did not leave the channel.

The track plots for proposed conditions, flood tide, with pilot 4 inbound and pilot 3 outbound are shown in Plates 27 and 28. The two ships met on Bloody Point Range, between buoys 10 and 12. The two ships were about $110 \mathrm{ft}$ apart, and neither ship left the channel. Both ships came close to the channel edge near buoy 14 , but neither crossed the authorized channel limits. The inbound ship left the channel by $40 \mathrm{ft}$ on the eastern end of Tybee Knoll Cut Range.

\section{Widener at turn between Tybee Range and Bloody Point Range}

Composite runs of all S-class containerships passing through the Tybee Roads wideners are shown in Figures 16 and 17. 


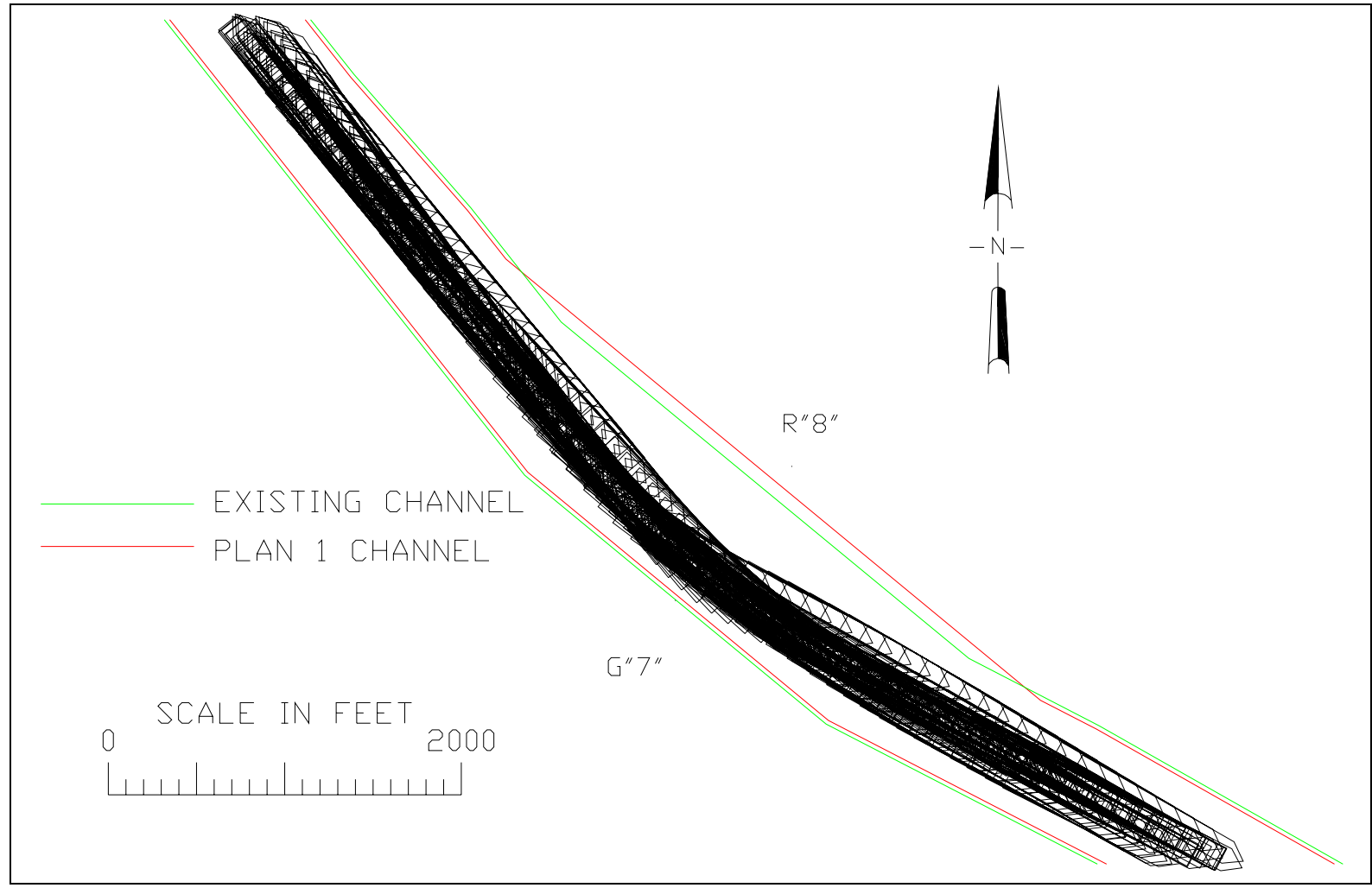

Figure 16. Composite S-class runs on turn between Tybee Range and Bloody Point Range

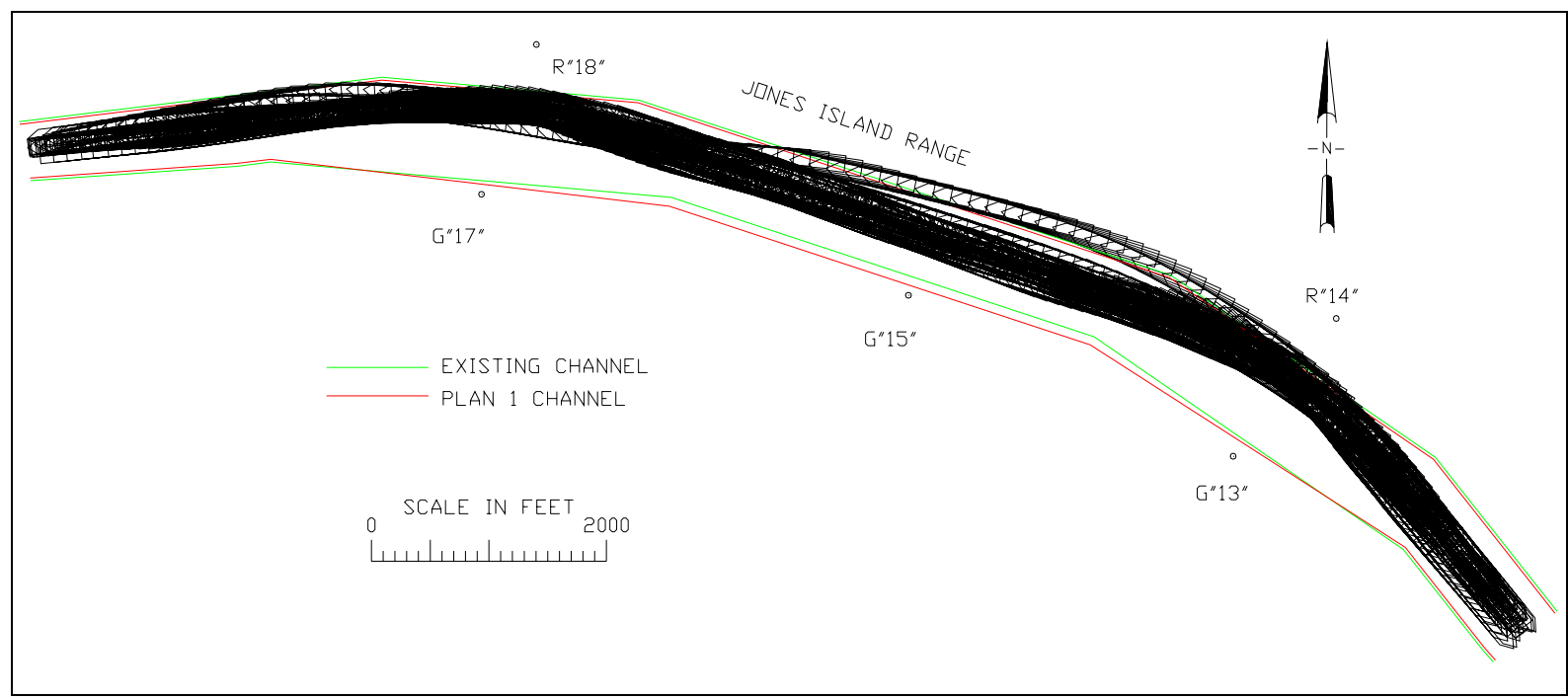

Figure 17. Jones Island Range - all S-class runs 


\section{Long Island Range}

The results for the Long Island Range simulations are presented in Plates 2072. Three channel layouts were simulated, existing, Plan 1, and Plan 2 . The difference between Plans 1 and 2 was that Plan 2 widened the south side of Long Island Range deepened channel by an additional $100 \mathrm{ft}$. Simulation runs were undertaken for two-way traffic operating in both ebb- and flood-tidal currents. The simulations' starting positions were adjusted so that the meeting occurred midway along Long Island Reach. The design ship for the existing channel was the $S L$ Performance loaded to $33 \mathrm{ft}$. The design ship for the proposed channel was the Susan Maersk loaded to $47.5 \mathrm{ft}$.

Two-way traffic of two S-class containerships was simulated with both Sclass containerships being conned by the pilot. The Savannah District desired to evaluate the meeting of the Susan Maersk and the SL Performance in both the Plan 1 and Plan 2 channels. This was accomplished without additional simulation runs by adding two computer-controlled ships to simulations of the proposed channels. Versions of the SL Performance ran both inbound and outbound. The starting time and position of the computer-controlled $S L$

Performance was set to ensure that the piloted Susan Maersk met the computercontrolled SL Performance prior to meeting the other pilot-controlled ship. Figure 18 shows all four ships in the visual scene. The simulator's Susan Maersk (ownship) ${ }^{1}$ is shown as the bow image. The ownship is inbound for this picture. The ownship is meeting an outbound computer-controlled version of the $S L$ Performance. Ownship's pilot can see the outbound pilot-controlled Susan Maersk (the other simulator's ownship). The outbound Susan Maersk has just met the inbound computer-controlled SL Performance. The computer-controlled ships ran on a straight line offset from the channel's edge.

The track plots for each simulation are presented on two plates to allow plotting at a readable scale. The western area is presented first, followed by eastern area. Both the western and eastern plates are plotted to the same scale.

\section{Existing conditions, ebb tide}

The track plots for existing conditions, ebb tide, with pilot 3 inbound and pilot 4 outbound are shown in Plates 29 and 30. The inbound ship left the channel by approximately $60 \mathrm{ft}$, west of buoy 24 . The two ships met near buoy 30. The inbound ship left the channel by nearly $50 \mathrm{ft}$ at the meeting, and the outbound ship ran along the channel edge. The outbound ship began the simulation too far to the east and was actually out of the Long Island Crossing Range. The outbound ship left the channel by approximately $50 \mathrm{ft}$ while turning into the New Channel Range. The ships were nearly $260 \mathrm{ft}$ apart when meeting.

\footnotetext{
${ }^{1}$ Ownship is the simulated vessel being controlled by the pilot at the helm. The other vessel in the simulator is referred to as the traffic ship.
} 


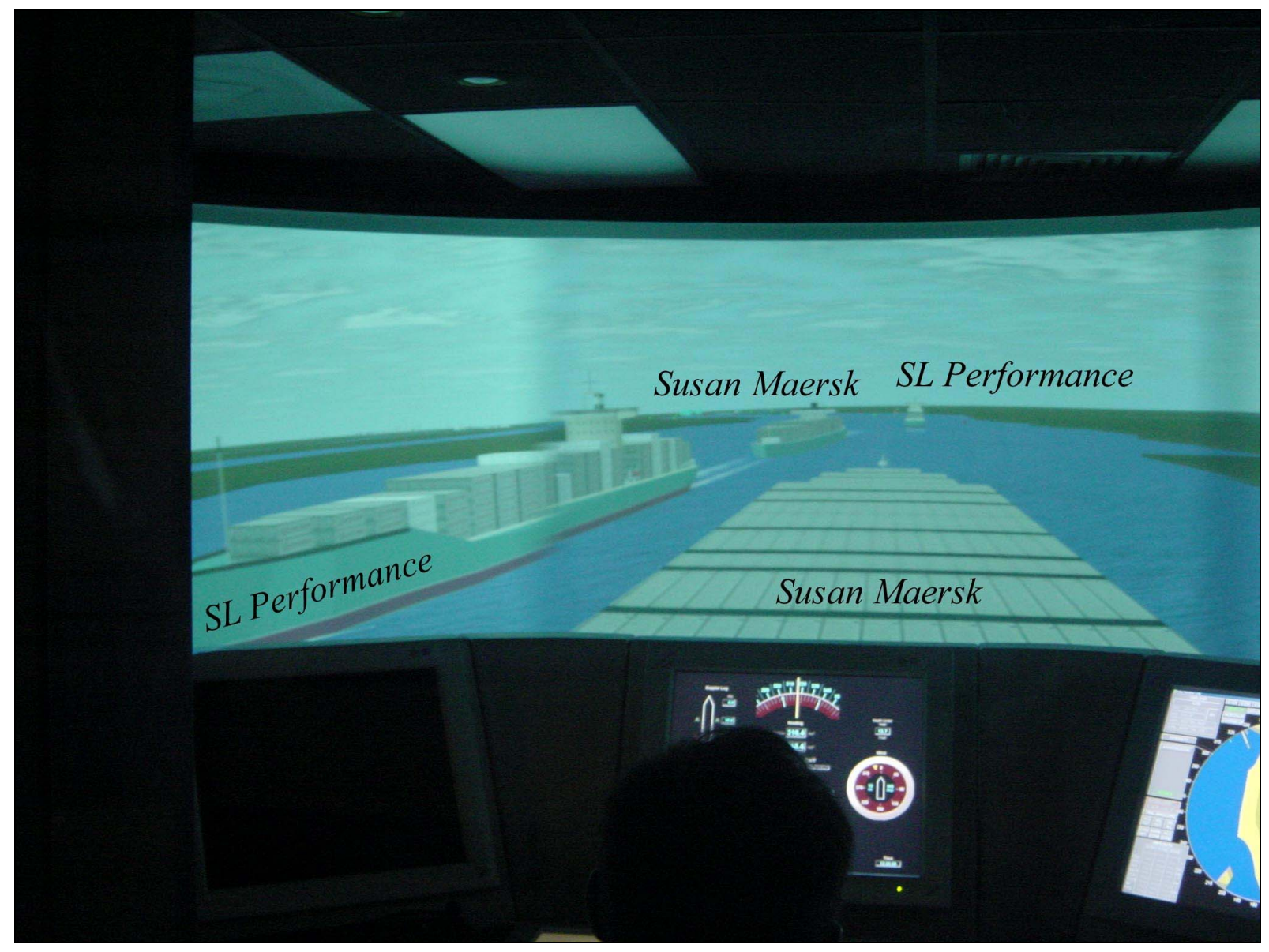

Figure 18. Ownship view of inbound Susan Maersk

The track plots for existing conditions, ebb tide, with pilot 4 inbound and pilot 3 outbound are shown in Plates 31 and 32. Neither ship left the channel until the meeting near buoy 30 . The inbound ship left the channel by nearly $45 \mathrm{ft}$ when meeting the outbound ship. The ships were nearly $310 \mathrm{ft}$ apart when meeting.

The track plots for existing conditions, ebb tide, with pilot 5 inbound and pilot 6 outbound are shown in Plates 33 and 34. Neither ship left the channel until the meeting near buoy 30 . The inbound ship left the channel by nearly $60 \mathrm{ft}$ when meeting the outbound ship, which left the channel by approximately $20 \mathrm{ft}$. The ships were nearly $335 \mathrm{ft}$ apart when meeting.

The track plots for existing conditions, ebb tide, with pilot 6 inbound and pilot 5 outbound are shown in Plates 35 and 36. The inbound ship went entirely out of the channel west of buoy 24. This incident occurred because the ship's wheel was turned hard to starboard when the simulation began. The pilot recovered and the run continued. Other than the inbound pilot's initial problem, neither ship left the channel until the meeting south of buoy 30 . Both ships left the channel at that point. The inbound ship went completely out of the channel and the 
outbound ship left the channel by almost $50 \mathrm{ft}$. The ships were separated by approximately $450 \mathrm{ft}$.

\section{Existing conditions, flood tide}

The track plots for existing conditions, flood tide, with pilot 3 inbound and pilot 4 outbound are shown in Plates 37 and 38. The meeting occurred just south of buoy 32. Both ships left the channel while meeting. The inbound ship just crossed the channel line, while the outbound ship went entirely out of the channel. The ships were nearly $500 \mathrm{ft}$ apart.

The track plots for existing conditions, flood tide, with pilot 4 inbound and pilot 3 outbound are shown in Plates 39 and 40. The ships met near buoy 30, with the outbound ship leaving the channel by about $80 \mathrm{ft}$. The separation distance between the two ships was nearly $240 \mathrm{ft}$. Neither ship left the channel at any other time during the run.

The track plots for existing conditions, flood tide, with pilot 6 inbound and pilot 5 outbound are shown in Plates 41 and 42. The ships met between buoys 30 and 32. The outbound ship ran along the channel edge while the inbound ship remained within the authorized channel. The ships were approximately $210 \mathrm{ft}$ apart at meeting.

\section{Plan 1 conditions, ebb tide}

The track plots for the Plan 1 conditions, ebb tide, with pilot 3 inbound and pilot 4 outbound are shown in Plates 43 and 44. The inbound ship left the channel by approximately $60 \mathrm{ft}$, west of buoy 24. The inbound Susan Maersk also clipped the channel edge while making the turn near buoy 28. This was probably caused by trying to remain on the east side of the channel in anticipation of meeting the outbound, computer-controlled, SL Performance. That meeting occurred between buoys 28 and 30 without any problems. The two Susan Maersks met between buoys 30 and 32. The outbound ship left the channel by nearly $100 \mathrm{ft}$ and the ships were separated by approximately $160 \mathrm{ft}$. After the ships met, the inbound ship left the channel by about $10 \mathrm{ft}$. The inbound ship also crossed the channel edge while making the turn into Lower Flats Range, across from buoy 33.

The track plots for the Plan 1 conditions, ebb tide, with pilot 4 inbound and pilot 3 outbound are shown in Plates 45 and 46. The inbound Susan Maersk clipped the channel edge while making the turn near buoy 28 while setting up to meet the outbound, computer-controlled, SL Performance. Neither piloted vessel had any difficulty meeting the computer-controlled ship. The piloted ships met between 30 and 32, with the inbound ship leaving the channel by $40 \mathrm{ft}$. There was $90 \mathrm{ft}$ between the ships. Neither ship had any difficulties in the Lower and Upper Flat Range reaches. The outbound ship left the channel by nearly $60 \mathrm{ft}$ while making the turn into the New Channel Range.

The track plots for the Plan 1 conditions, ebb tide, with pilot 5 inbound and pilot 6 outbound are shown in Plates 47 and 48. The inbound Susan Maersk 
clipped the channel edge while making the turn near buoy 28 while setting up to meet the outbound, computer-controlled, SL Performance. Neither piloted vessel had any difficulty meeting the computer controlled ship. The piloted ships met between buoys 30 and 32, with the inbound ship leaving the channel by nearly $85 \mathrm{ft}$ on the east side of the channel. After meeting, the ship-ship interaction forces caused the inbound ship to leave the west side of the channel by nearly $15 \mathrm{ft}$. The outbound ship left the Upper Flat Range area twice. The first occurred just south of the LNG terminal. This appeared to be caused by the ship's initial heading. The second was by about $30 \mathrm{ft}$ as the ship approached the turn near buoy 39 . The ships were approximately $60 \mathrm{ft}$ apart when they met.

The track plots for the Plan 1 conditions, ebb tide, with pilot 6 inbound and pilot 5 outbound are shown in Plates 49 and 50. The inbound ship left the channel by approximately $60 \mathrm{ft}$ while making the turn onto the New Channel Range, west of buoy 24. The inbound Susan Maersk clipped the channel edge while making the turn near buoy 28 while setting up to meet the outbound, computer-controlled, SL Performance. The inbound Susan Maersk crossed the channel limits while meeting the outbound, computer-controlled, $S L$ Performance. The two Susan Maersks met just north of buoy 30. The inbound ship left the channel by nearly $30 \mathrm{ft}$. The two ships were separated by about 65 $\mathrm{ft}$. The outbound ship left the channel just south of the LNG terminal, due to the ship's initial heading.

\section{Plan 1 conditions, flood tide}

The track plots for the Plan 1 conditions, flood tide, with pilot 3 inbound and pilot 4 outbound are shown in Plates 51 and 52. The two Susan Maersks meet just south of buoy 32. The outbound ship left the channel by about $30 \mathrm{ft}$ and the two ships were about $65 \mathrm{ft}$ apart. There were no other incidents by either ship during the exercise.

The track plots for the Plan 1 conditions, flood tide, with pilot 4 inbound and pilot 3 outbound are shown in Plates 53 and 54. The inbound Susan Maersk left the channel by about $30 \mathrm{ft}$ on the south side of the channel between buoys 26 and 28. The two piloted ships met just north of buoy 30 . The outbound ship left the channel by about $75 \mathrm{ft}$ and the two ships were nearly $65 \mathrm{ft}$ apart. The inbound Susan Maersk left the channel by about $15 \mathrm{ft}$ on the north side of Lower Flats Range.

The track plots for the Plan 1 conditions, flood tide, with pilot 5 inbound and pilot 6 outbound are shown in Plates 55 and 56. The two piloted ships met between buoys 30 and 32. The outbound ship went entirely out of the channel during the meeting. The inbound ship left the north side of the channel by about $40 \mathrm{ft}$, across from buoy 35 .

The track plots for the Plan 1 conditions, flood tide, with pilot 6 inbound and pilot 5 outbound are shown in Plates 57 and 58. The two Susan Maersks met between of buoys 30 and 32. Both ships went about $50 \mathrm{ft}$ out of the channel and were about $90 \mathrm{ft}$ apart. The outbound ship left the north side of the channel by about $15 \mathrm{ft}$, across from buoy 35 . 


\section{Plan 2 conditions, ebb tide}

The track plots for the Plan 2 conditions, ebb tide, with pilot 3 inbound and pilot 4 outbound are shown in Plates 59 and 60. The inbound Susan Maersk clipped the channel edge while turning onto the New Channel Range. The inbound ship also clipped the channel edge while making the turn near buoy 28 while setting up to meet the outbound, computer-controlled, SL Performance. The two Susan Maersks met between of buoys 30 and 32. The outbound ship ran along the channel's edge and the two ships were about $170 \mathrm{ft}$ apart when they met. The outbound Susan Maersk went far into the turning basin across from the LNG terminal due the ship's initial heading.

The track plots for the Plan 2 conditions, ebb tide, with pilot 4 inbound and pilot 3 outbound are shown in Plates 61 and 62. The inbound Susan Maersk clipped the channel edge while turning onto the New Channel Range. The twopiloted ships met just north of buoy 30 . Neither ship left the channel, although the outbound ship did go to the channel's edge. The ships were $125 \mathrm{ft}$ apart when they met. The outbound ship left the channel by nearly $40 \mathrm{ft}$ when making the turn onto the New Channel Range.

The track plots for the Plan 2 conditions, ebb tide, with pilot 5 inbound and pilot 6 outbound are shown in Plates 63 and 64. The two Susan Maersks met near buoy 32. Both ships stayed within the channel limits and were $110 \mathrm{ft}$ apart when they met. The outbound ship left the channel by nearly $50 \mathrm{ft}$ when making the turn onto the New Channel Range.

\section{Plan 2 conditions, flood tide}

The track plots for the Plan 2 conditions, flood tide, with pilot 3 inbound and pilot 4 outbound are shown in Plates 65 and 66. The two Susan Maersks met near buoy 32. Although the outbound ship ran along the channel edge during the meeting, both ships stayed within the channel limits. The ships were approximately $125 \mathrm{ft}$ apart when they met.

The track plots for the Plan 2 conditions, flood tide, with pilot 4 inbound and pilot 3 outbound are shown in Plates 67 and 68. The two Susan Maersks met just north of buoy 30 . Although the outbound ship ran along the channel edge during the meeting, both ships stayed within the channel limits. The ships were nearly $100 \mathrm{ft}$ apart when they met.

The track plots for the Plan 2 conditions, flood tide, with pilot 5 inbound and pilot 6 outbound are shown in Plates 69 and 70. The two Susan Maersks met between buoys 30 and 32. Although the outbound ship ran along the channel edge during the meeting, both ships stayed within the channel limits. The ships were about $110 \mathrm{ft}$ apart when they met.

The track plots for the Plan 2 conditions, flood tide, with pilot 6 inbound and pilot 5 outbound are shown in Plates 71 and 72. The inbound Susan Maersk clipped the channel edge while making the turn near buoy 28 while setting up to meet the outbound, computer-controlled, SL Performance. The two Susan 
Maersks met just north of buoy 30 . Both ships went about $30 \mathrm{ft}$ out of the channel while meeting. The ships were $130 \mathrm{ft}$ apart when they met.

\section{Wideners for Long Island Range tests}

Composite runs of all S-class containerships passing through the Long Island Range wideners are shown in Figures 19 and 20.

\section{The Bight and Fort Jackson Area}

The results for the Bight and Fort Jackson Area simulations are presented in Plates 73-97. Three channel layouts were tested in this area. Two proposed channel configurations were tested. These two plans are referred to as Plan 2 and Plan 3. Plan 1 was eliminated during preliminary testing. The existing, Plan 2, and Plan 3 channels were simulated for two-way traffic operating in both ebband flood-tidal currents. The design ship for the existing channel was the $S L$ Performance, loaded to $33 \mathrm{ft}$. The design ship for the Plan 2 and Plan 3 channels was the Susan Maersk, loaded to $47.5 \mathrm{ft}$.

\section{Existing conditions, ebb tide}

The track plot for existing conditions, ebb tide, with pilot 1 inbound and pilot 2 outbound is shown in Plate 73. Both the inbound and outbound ship stayed to the north side of the channel while making the turn through the Bight. The outbound ship left the channel by nearly $85 \mathrm{ft}$ near buoy 44 . The ships met in Fort Jackson Range near buoy 50. The ships kept far apart and the outbound ship left the channel by nearly $65 \mathrm{ft}$. The ships were about $265 \mathrm{ft}$ apart when they met. The inbound ship went more than $60 \mathrm{ft}$ out of the channel west of buoy 52 and by $40 \mathrm{ft}$ on the north side of the Wrecks Channel.

The track plot for existing conditions, ebb tide, with pilot 4 inbound and pilot 3 outbound is shown in Plate 74. Both the inbound and outbound ship stayed to the north side of the channel while making the turn through the Bight. The outbound ship went nearly $120 \mathrm{ft}$ out of the channel west of buoy 48 . The inbound ship went completely out of the channel at the same point. The ships met on Oglethorpe Range, west of buoy 52. The inbound ship went completely out of the channel during the meeting. The ships were nearly $300 \mathrm{ft}$ apart at this point. The inbound ship also left the north side of the Wrecks Channel by nearly $80 \mathrm{ft}$.

The track plot for existing conditions, ebb tide, with pilot 5 inbound and pilot 6 outbound is shown in Plate 75. The inbound ship left the north side of the channel twice, once west of buoy 42 and again west of buoy 48 . The outbound ship left the channel by $90 \mathrm{ft}$ while making the turn through the Bight. The ships met on Oglethorpe Range. The inbound ship went completely out of the channel west of buoy 52 . The ships were nearly $280 \mathrm{ft}$ apart when they met. 


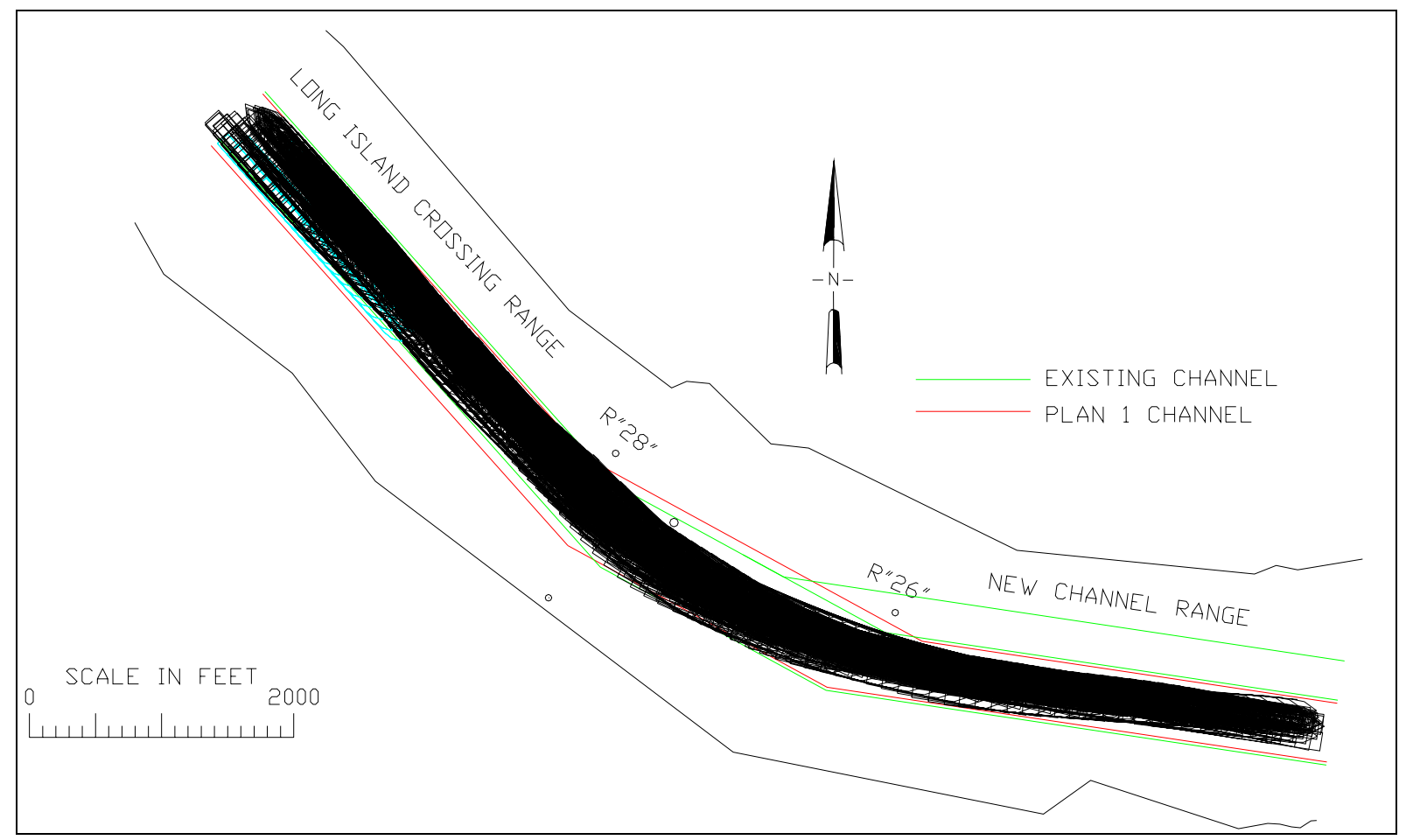

Figure 19. Composite plot of all S-class runs through New Channel Range widener

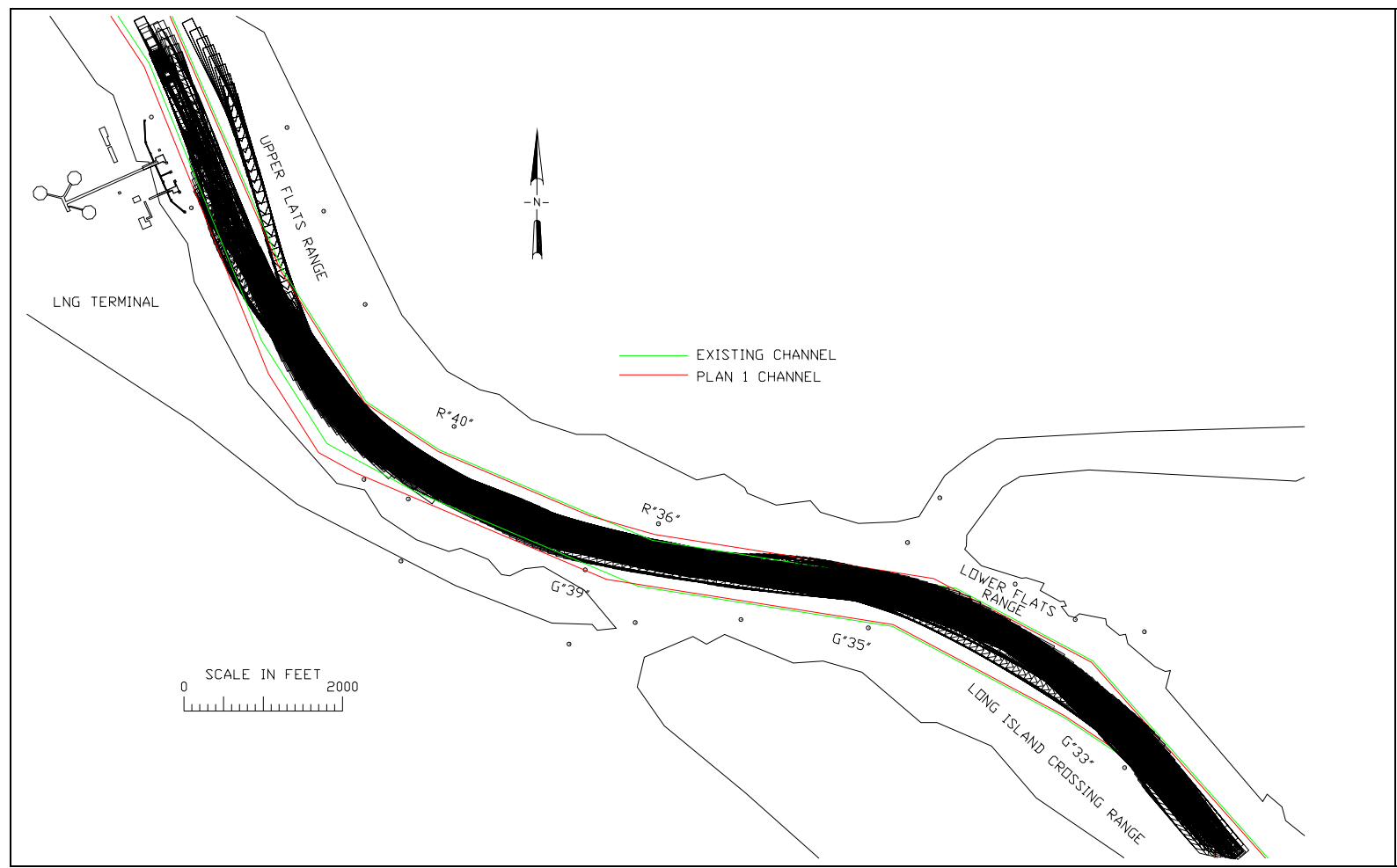

Figure 20. Composite plot of all S-class runs through Flats Range area wideners 
The track plot for existing conditions, ebb tide, with pilot 6 inbound is shown in Plate 76. Pilot 5 was outbound for this run, but due to a simulator error, the data for the outbound ship was destroyed. The inbound ship left the channel by nearly $30 \mathrm{ft}$ west of buoy 44 . The inbound ship left the Oglethorpe Range by nearly $140 \mathrm{ft}$ while meeting the outbound ship. The inbound ship left the channel by nearly $50 \mathrm{ft}$ near buoy 58 .

\section{Existing conditions, flood tide}

The track plot for existing conditions, flood tide, with pilot 3 inbound and pilot 4 outbound is shown in Plate 77. The inbound ship made the turn through the Bight by staying about $100 \mathrm{ft}$ out of the channel. The outbound ship stayed in the center of the channel while making the same turn. The inbound ship left the Fort Jackson Range by $100 \mathrm{ft}$ near buoy 50. The ships met on Oglethorpe Range with both ships staying about $110 \mathrm{ft}$ from the channel edge and nearly 125 $\mathrm{ft}$ apart. The outbound ship cut across the Fig Island Turning Basin.

The track plot for existing conditions, flood tide, with pilot 4 inbound and pilot 3 outbound is shown in Plate 78. The inbound ship made the turn through the Bight by staying about $100 \mathrm{ft}$ out of the channel. The inbound ship went to the west channel edge near buoy 50 , but did not go out of the channel. The ships met on Oglethorpe Range, between buoys 52A and 53. The inbound ship went nearly $90 \mathrm{ft}$ out of the channel during the meeting and the ships were about $210 \mathrm{ft}$ apart. The outbound ship left the north side of the channel just east of the Fig Island Turning Basin.

The track plot for existing conditions, flood tide, with pilot 5 inbound and pilot 6 outbound is shown in Plate 79. The inbound ship made the turn through the Bight by staying about $100 \mathrm{ft}$ out of the channel. The outbound ship remained in the center of the channel while making the turn. The two ships met on the western end of Oglethorpe Reach. The inbound ship went entirely out of the channel and the ships were about $250 \mathrm{ft}$ apart while meeting.

The track plot for existing conditions, flood tide, with pilot 6 inbound and pilot 5 outbound is shown in Plate 80. The outbound pilot asked to be started in the Bight, to the far north of the channel. The outbound ship made the turn through the Bight by staying the center of the channel. The two ships met on Oglethorpe Range and the inbound ship went entirely out of the channel. The ships were over $300 \mathrm{ft}$ apart when they met. The inbound ship left the channel by about $50 \mathrm{ft}$ at the eastern end of the Fig Island Turning Basin.

\section{Plan 2 conditions, ebb tide}

The track plot for Plan 2 conditions, ebb tide, with pilot 2 inbound and pilot 1 outbound is shown in Plate 81 . Neither ship left the channel while turning through the Bight. The inbound ship left the channel when the two ships met near buoy 50. The inbound ship went about $80 \mathrm{ft}$ out of the north side of the Wrecks Channel. 
The track plot for Plan 2 conditions, ebb tide, with pilot 3 inbound and pilot 4 outbound is shown in Plate 82. Neither ship left the channel while turning through the Bight. Both ships went out of the channel while meeting near buoy 52 .

The track plot for Plan 2 conditions, ebb tide, with pilot 4 inbound and pilot 3 outbound is shown in Plate 83. The inbound ship left the north side of the channel by about $20 \mathrm{ft}$ while turning through the Bight. The outbound ship turned through the Bight without leaving the channel. Both ships went out of the channel while meeting near buoy 52 .

The track plot for Plan 2 conditions, ebb tide, with pilot 5 inbound and pilot 6 outbound is shown in Plate 84. Both ships completed the exercise without leaving the channel. The ships were about $50 \mathrm{ft}$ apart when they met.

The track plot for Plan 2 conditions, ebb tide, with pilot 6 inbound and pilot 5 outbound is shown in Plate 85. The inbound Susan Maersk left the north side of the channel between buoys 42 and 44 . Both ships left the channel by less than 30 $\mathrm{ft}$ while meeting just north of buoy 50 .

\section{Plan 2 conditions, flood tide}

The track plot for Plan 2 conditions, flood tide, with pilot 3 inbound and pilot 4 outbound is shown in Plate 86 . The inbound ship went about $100 \mathrm{ft}$ out of the channel while making the turn out of the Bight. The ships met just east of buoys $52 \mathrm{~A}$ and 53 . The inbound ship left the channel during the meeting. Immediately after the meeting, the simulator output file was corrupted and nearly $2000 \mathrm{ft}$ of data for the inbound ship was lost for this run. The inbound ship also left the Wrecks Channel by about $20 \mathrm{ft}$. The outbound ship remained within the authorized channel for the entire duration of the exercise.

The track plot for Plan 2 conditions, flood tide, with pilot 4 inbound and pilot 3 outbound is shown in Plate 87. The inbound ship left the north side of the channel by about $25 \mathrm{ft}$ while making the turn out of the Bight. The two ships met east of buoy 52A, where the inbound ship left the channel by about $75 \mathrm{ft}$. The outbound ship remained within the authorized channel for the entire duration of the exercise.

The track plot for Plan 2 conditions, flood tide, with pilot 5 inbound and pilot 6 outbound is shown in Plate 88. The two ships met between buoys 52A and 53 , where the inbound ship left the channel by about $70 \mathrm{ft}$. The inbound ship also left the Wrecks Channel by about $40 \mathrm{ft}$. The outbound ship remained within the authorized channel for the entire duration of the exercise.

The track plot for Plan 2 conditions, flood tide, with pilot 6 inbound and pilot 5 outbound is shown in Plate 89 . The inbound ship left the channel by about $15 \mathrm{ft}$ south of buoy 44 . The two ships met east of buoys 52A and 53, where the inbound ship left the channel by about $35 \mathrm{ft}$. The inbound ship left the channel near buoy 58. The outbound ship remained within the authorized channel for the entire duration of the exercise. 


\section{Plan 3 conditions, ebb tide}

The track plot for Plan 3 conditions, ebb tide, with pilot 3 inbound and pilot 4 outbound is shown in Plate 90. The inbound ship went too far north while approaching the Bight and went entirely out of the channel near buoy 44. The outbound ship also went out of the channel in the Bight, by about $25 \mathrm{ft}$ near buoy 48. The inbound ship went completely out of the channel while meeting the outbound ship on Oglethorpe Range. The outbound ship swung its stern nearly $125 \mathrm{ft}$ out while making the turn on the eastern end of Oglethorpe Range. The outbound ship also left the channel by approximately $60 \mathrm{ft}$ west of buoy 53 and by about $130 \mathrm{ft}$ across from buoy 57 .

The track plot for Plan 3 conditions, ebb tide, with pilot 4 inbound and pilot 3 outbound is shown in Plate 91. Both the inbound and outbound ships left the north side of the channel while turning through the Bight. The outbound ship remained about $80 \mathrm{ft}$ out of the channel throughout most of the turn, while the inbound ship went about $125 \mathrm{ft}$ out, west of buoy 48. Both ships left the channel near buoy 50 . The inbound ship left by approximately $40 \mathrm{ft}$, while the outbound left the channel by nearly $80 \mathrm{ft}$. Both ships were approximately $100 \mathrm{ft}$ out of the channel while meeting on Oglethorpe Range. The outbound ship left the north side of the Wrecks Channel by nearly $90 \mathrm{ft}$.

The track plot for Plan 3 conditions, ebb tide, with pilot 6 inbound and pilot 5 outbound is shown in Plate 92. Both the inbound and outbound ship ran the Bight with their ships about halfway out of the channel. The ships met between buoys 50 and 52. Both ships left the channel while meeting. The inbound ship left the east side of the channel by about $50 \mathrm{ft}$, while the outbound ship left the west side by nearly $250 \mathrm{ft}$. The inbound ship left the Wreck Channel by over $100 \mathrm{ft}$.

\section{Plan 3 conditions, flood tide}

The track plot for Plan 3 conditions, flood tide, with pilot 2 inbound and pilot 1 outbound is shown in Plate 93. The inbound ship kept its stern outside the channel edge while turning through the Bight, and remained out of the channel until past buoy 50 . The inbound ship left the east side of the channel near buoy 49, while approaching the Bight, but remained within the channel limits while turning through the Bight. The ships met on Oglethorpe Range, with the inbound and outbound ships leaving the channel by approximately 50 and $15 \mathrm{ft}$, respectively. The outbound ship went entirely out of the Wrecks Channel.

The track plot for Plan 3 conditions, flood tide, with pilot 3 inbound and pilot 4 outbound is shown in Plate 94. The inbound ship left the channel while entering and leaving the Bight, each time by about $20 \mathrm{ft}$. The two ships met on Oglethorpe Range, with the inbound ship leaving the channel by about $45 \mathrm{ft}$. The inbound ship left the north side of the channel across from buoy 57.

The track plot for Plan 3 conditions, flood tide, with pilot 4 inbound and pilot 3 outbound is shown in Plate 95. The inbound ship ran outside the channel while making the turn through the Bight, while the outbound ship remained 
within the channel limits. The ships met in Oglethorpe Range where the inbound ship left the channel by approximately $30 \mathrm{ft}$. The inbound ship left the south side of the channel across from buoy 56 and both ships left the north side of Wrecks Channel.

The track plot for Plan 3 conditions, flood tide, with pilot 5 inbound and pilot 6 outbound is shown in Plate 96. The inbound ship left the channel while entering and leaving the Bight, each time by about $20 \mathrm{ft}$. The two ships met near buoy 52 and were both about $20 \mathrm{ft}$ out of the channel.

The track plot for Plan 3 conditions, flood tide, with pilot 6 inbound and pilot 5 outbound is shown in Plate 97. The inbound ship stayed outside the channel while turning through the Bight. The outbound ship left the channel while entering and leaving the Bight. The ships met on Oglethorpe Range with the inbound ship leaving the channel by approximately $100 \mathrm{ft}$. Both ships left the north side of the Wrecks Channel.

\section{City Front}

A limited number of simulations were conducted for the City Front Reach. They were two-way simulations and they are shown in Plates 98-101. The $S L$ Performance was used for existing conditions and the Susan Maersk was used for the Plan 1 channel.

Track plots for the ebb-and flood-tide runs in the existing channel are shown in Plates 98 and 99, respectively. The existing condition run for ebb tide, with pilot 6 inbound and pilot 5 outbound is shown in Plate 98. The outbound ship got caught in the ebb-tidal currents and left the western end of City Front Channel by about $150 \mathrm{ft}$. The two ships met near the bend in City Front Channel, near buoy 62 . Both ships left the channel during the meeting. The inbound ship left the channel by about $50 \mathrm{ft}$ and the outbound by nearly $20 \mathrm{ft}$. The inbound ship left the north side of the Wrecks Channel by about $50 \mathrm{ft}$. The existing condition run for flood tide, with pilot 6 inbound and pilot 5 outbound is shown in Plate 99. The two ships met near the western end of City Front Channel. The inbound ship left the north side of the channel by approximately $20 \mathrm{ft}$ while meeting the outbound ship.

Track plots for the ebb- and flood-tide runs in the Plan 1 channel are shown in Plates 100 and 101, respectively. The Plan 1 condition run for ebb tide, with pilot 5 inbound and pilot 6 outbound is shown in Plate 100. The two ships met near the bend in City Front Channel, near buoy 62. The inbound ship cut the corner on the northern side of the channel just after meeting and left the channel by approximately $125 \mathrm{ft}$. The Plan 1 condition run for flood tide, with pilot 5 inbound and pilot 6 outbound is shown in Plate 101. The ships met near the bend in City Front Channel, near buoy 62. The outbound ship left the south side of the channel, during meeting, by nearly $25 \mathrm{ft}$. The inbound ship left the channel by approximately $125 \mathrm{ft}$ while preparing to meet the outbound ship. 


\section{Kings Island}

Four simulations were conducted for the Kings Island Reach. They were oneway simulations and they are shown in Plates 102-105. The Susan Maersk was used for all four exercises.

Two outbound runs were conducted during ebb tide. The track plots for these scenarios are shown in Plates 102 and 103. The runs were completed without incident. One outbound run with flood tide was simulated and the track plot is shown in Plate 104. The ship stayed to port side of the channel for the most part, leaving the channel twice by about $10 \mathrm{ft}$. The inbound run with flood tide was ended with the ship turning in the Kings Island Turning Basin. This exercise is shown in Plate 105. The run was completed without incident. The ship stayed close to the west side of the channel while turning, leaving a clearance of over $300 \mathrm{ft}$ off its bow. The proposed Kings Island Turning Basin has a diameter of $1,650 \mathrm{ft}$. This proved to be adequate when turning the 1,140-ft-long Susan Maersk.

\section{Additional Runs with 43-ft Draft Susan Maersk}

After completion of the initial simulations, a series of runs were conducted with the Susan Maersk's draft set to $43 \mathrm{ft}$. This was done to determine if the 43 -ft-draft vessel required less bend widening than when drafting $47.5 \mathrm{ft}$. With 4.5-ft less draft, the Susan Maersk should handle a little easier and possibly not require the additional room in the bends. These simulations were conducted with four Savannah Harbor pilots during October and November 2003. Results from that session are compared with the 47.5-ft Susan Maersk. The track plots are a composite with $47.5-\mathrm{ft}$ runs shown in black and the 43 - $\mathrm{ft}$ runs shown in grey.

A composite track plot comparing the 43-ft Susan Maersk and the 47.5-ft Susan Maersk are through the turn between Tybee and Blood Point Ranges is shown in Figure 21. These plots show little difference in runs between the two drafts.

A composite track plot comparing the 43-ft Susan Maersk and the 47.5-ft Susan Maersk through the turn between Jones Island Range turn is shown in Figure 22. These plots show little difference in runs between the two drafts.

A composite track plot comparing the 43-ft Susan Maersk and the 47.5-ft Susan Maersk through the turn between Upper and Lower Flats Ranges is shown in Figure 23. As with the preceding plots there is little difference in runs between the two drafts.

Comparisons between simulations of the Susan Maersk drafting 43 and $47.5 \mathrm{ft}$ indicate that the same bend wideners are required for both drafts. 


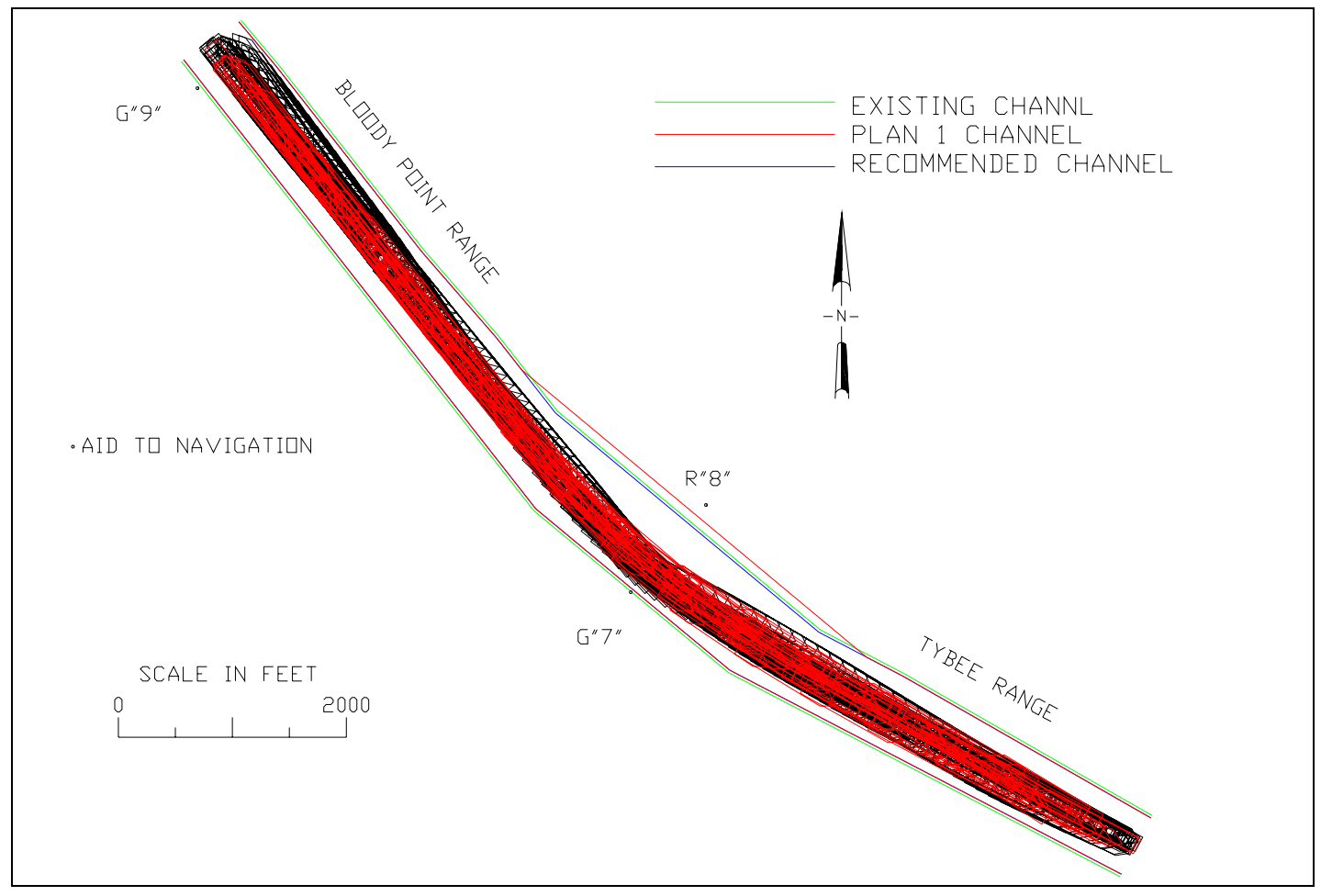

Figure 21. 43-ft draft Susan Maersk at turn between Tybee and Bloody Point Ranges

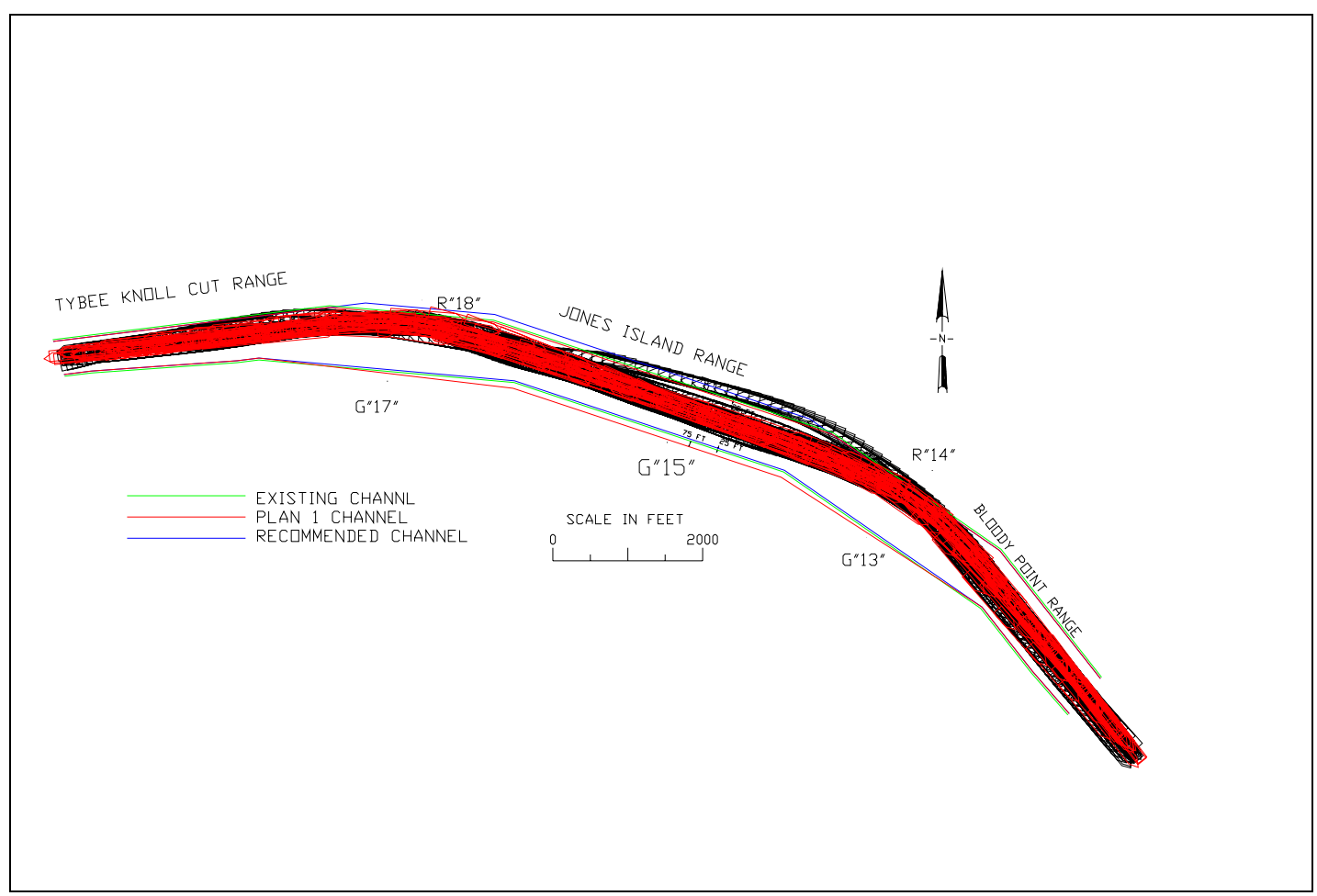

Figure 22. 43-ft draft Susan Maersk at Jones Island Range Turn 


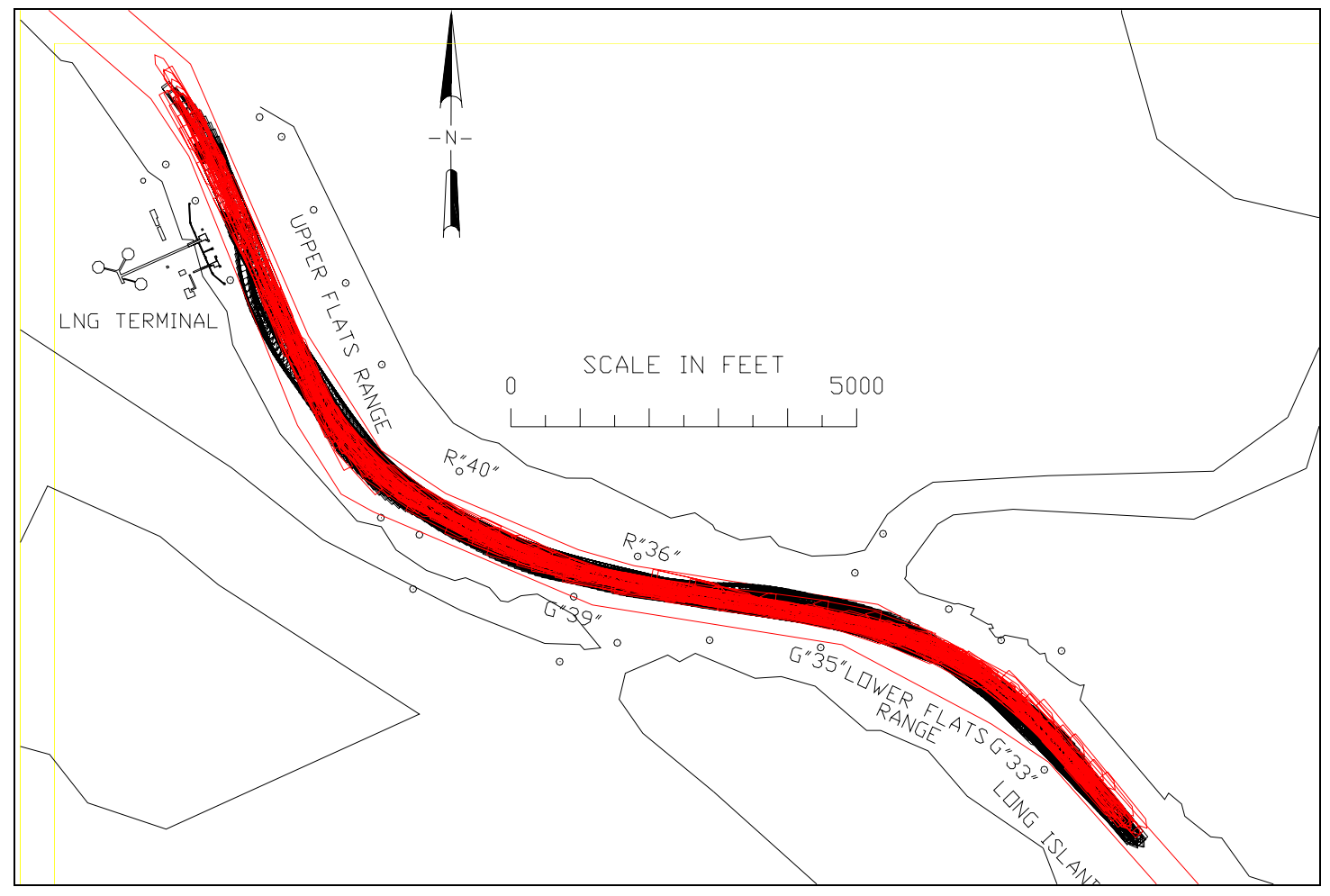

Figure 23. 43-ft Susan Maersk through Upper and Lower Flats Ranges

\section{Vertical Motion Study}

A vertical motion study was conducted to evaluate channel depth requirements. A series of simulations with a computer-controlled ship transiting Tybee Range were conducted. Two drafts of the Susan Maersk were simulated, $46 \mathrm{ft}$ and $47.5 \mathrm{ft}$. Wave conditions were selected based upon a concurrent wave modeled study conducted at ERDC (Thompson, in preparation). ${ }^{1}$ Based upon analysis of the 35 percent highest waves the following conditions were chosen.

a. Waves were coming from a direction of $215 \mathrm{deg}$.

b. Wave heights of 6,8 and $10 \mathrm{ft}$ were simulated.

c. Wave periods of 8 and $10 \mathrm{sec}$ were simulated.

Water depths from 48 to $56 \mathrm{ft}$ were simulated, in 1-ft increments. Water depth is defined as the authorized channel depth plus tide. Therefore, a water depth of $54 \mathrm{ft}$ could represent either a $54-\mathrm{ft}$ channel at low water, or a $50-\mathrm{ft}$ channel with $4 \mathrm{ft}$ of tide.

\footnotetext{
${ }^{1}$ Thompson, op cit., p. 11.
} 
The vertical motion model used was developed by Tracor Hydronautics and operated in fast-time. The simulated ship maneuvered with computer-controlled speed and heading based upon input conditions.

Results of the vertical motion study are presented in Table 1 and Plates 106135 for the Susan Maersk at a 47.5-ft draft and in Table 2 and Plates 136-171 for the Susan Maersk at a 46.0-ft draft. 


\begin{tabular}{|c|c|c|c|c|}
\hline $\begin{array}{l}\text { Plate } \\
\text { Number }\end{array}$ & $\begin{array}{l}\text { Channel Depth, } \\
\mathrm{ft}\end{array}$ & Wave Height, ft & $\begin{array}{l}\text { Wave Period, } \\
\text { sec }\end{array}$ & $\begin{array}{l}\text { Minimum } \\
\text { Clearance, } \mathrm{ft}\end{array}$ \\
\hline 106 & 52 & 6 & 8 & Grounded \\
\hline 107 & 53 & 6 & 8 & 1 \\
\hline 108 & 54 & 6 & 8 & 1.8 \\
\hline 109 & 55 & 6 & 8 & 2.7 \\
\hline 110 & 56 & 6 & 8 & 3.9 \\
\hline 111 & 52 & 8 & 8 & Grounded \\
\hline 112 & 53 & 8 & 8 & 0.6 \\
\hline 113 & 54 & 8 & 8 & 1.6 \\
\hline 114 & 55 & 8 & 8 & 2.6 \\
\hline 115 & 56 & 8 & 8 & 3.8 \\
\hline 116 & 52 & 10 & 8 & Grounded \\
\hline 117 & 53 & 10 & 8 & 0.5 \\
\hline 118 & 54 & 10 & 8 & 1.6 \\
\hline 119 & 55 & 10 & 8 & 2.5 \\
\hline 120 & 56 & 10 & 8 & 3.4 \\
\hline 121 & 52 & 6 & 10 & Grounded \\
\hline 122 & 53 & 6 & 10 & 0.9 \\
\hline 123 & 54 & 6 & 10 & 1.8 \\
\hline 124 & 55 & 6 & 10 & 2.6 \\
\hline 125 & 56 & 6 & 10 & 3.7 \\
\hline 126 & 52 & 8 & 10 & Grounded \\
\hline 127 & 53 & 8 & 10 & 0.5 \\
\hline 128 & 54 & 8 & 10 & 1.4 \\
\hline 129 & 55 & 8 & 10 & 2.5 \\
\hline 130 & 56 & 8 & 10 & 3.6 \\
\hline 131 & 52 & 10 & 10 & Grounded \\
\hline 132 & 53 & 10 & 10 & 0.3 \\
\hline 133 & 54 & 10 & 10 & 1.2 \\
\hline 134 & 55 & 10 & 10 & 2.4 \\
\hline 135 & 56 & 10 & 10 & 3.5 \\
\hline
\end{tabular}




\begin{tabular}{|c|c|c|c|c|}
\hline $\begin{array}{l}\text { Plate } \\
\text { Number }\end{array}$ & $\begin{array}{l}\text { Channel Depth, } \\
\mathrm{ft}\end{array}$ & $\begin{array}{l}\text { Wave Height, } \\
\mathrm{ft}\end{array}$ & $\begin{array}{l}\text { Wave Period, } \\
\text { sec }\end{array}$ & $\begin{array}{l}\text { Minimum Clearance, } \\
\mathrm{ft}\end{array}$ \\
\hline 136 & 51 & 6 & 8 & 0.6 \\
\hline 137 & 52 & 6 & 8 & 1.5 \\
\hline 138 & 53 & 6 & 8 & 2.2 \\
\hline 139 & 54 & 6 & 8 & 3.1 \\
\hline 140 & 55 & 6 & 8 & 4.1 \\
\hline 141 & 56 & 6 & 8 & 5.2 \\
\hline 142 & 51 & 8 & 8 & 0.3 \\
\hline 143 & 52 & 8 & 8 & 1.2 \\
\hline 144 & 53 & 8 & 8 & 2.0 \\
\hline 145 & 54 & 8 & 8 & 3.0 \\
\hline 146 & 55 & 8 & 8 & 4.0 \\
\hline 147 & 56 & 8 & 8 & 5.0 \\
\hline 148 & 51 & 10 & 8 & Grounded \\
\hline 149 & 52 & 10 & 8 & 1.1 \\
\hline 150 & 53 & 10 & 8 & 1.7 \\
\hline 151 & 54 & 10 & 8 & 2.9 \\
\hline 152 & 55 & 10 & 8 & 3.9 \\
\hline 153 & 56 & 10 & 8 & 4.8 \\
\hline 154 & 51 & 6 & 10 & 0.3 \\
\hline 155 & 52 & 6 & 10 & 1.4 \\
\hline 156 & 53 & 6 & 10 & 2.1 \\
\hline 157 & 54 & 6 & 10 & 3.1 \\
\hline 158 & 55 & 6 & 10 & 4.0 \\
\hline 159 & 56 & 6 & 10 & 5.0 \\
\hline 160 & 51 & 8 & 10 & 0.1 \\
\hline 161 & 52 & 8 & 10 & 1.2 \\
\hline 162 & 53 & 8 & 10 & 2.0 \\
\hline 163 & 54 & 8 & 10 & 3.0 \\
\hline 164 & 55 & 8 & 10 & 3.9 \\
\hline 165 & 56 & 8 & 10 & 5.0 \\
\hline 166 & 51 & 10 & 10 & Grounded \\
\hline 167 & 52 & 10 & 10 & 1.1 \\
\hline 168 & 53 & 10 & 10 & 1.8 \\
\hline 169 & 54 & 10 & 10 & 2.9 \\
\hline 170 & 55 & 10 & 10 & 3.9 \\
\hline 171 & 56 & 10 & 10 & 4.9 \\
\hline
\end{tabular}




\section{Conclusions and Recommendations}

Recommendations are presented from the Atlantic Ocean, heading inland.

The Tybee Range Channel may be improved as per the Plan 1. Deepening to $48 \mathrm{ft}$ on the existing side slopes will result in a 550-ft-wide channel. The widener on the north side of the turn between Tybee Range and Bloody Point Range was not used during any of the S-class simulations. Therefore, it is recommended that the channel be deepened on its existing side slopes as shown in Figure 24.

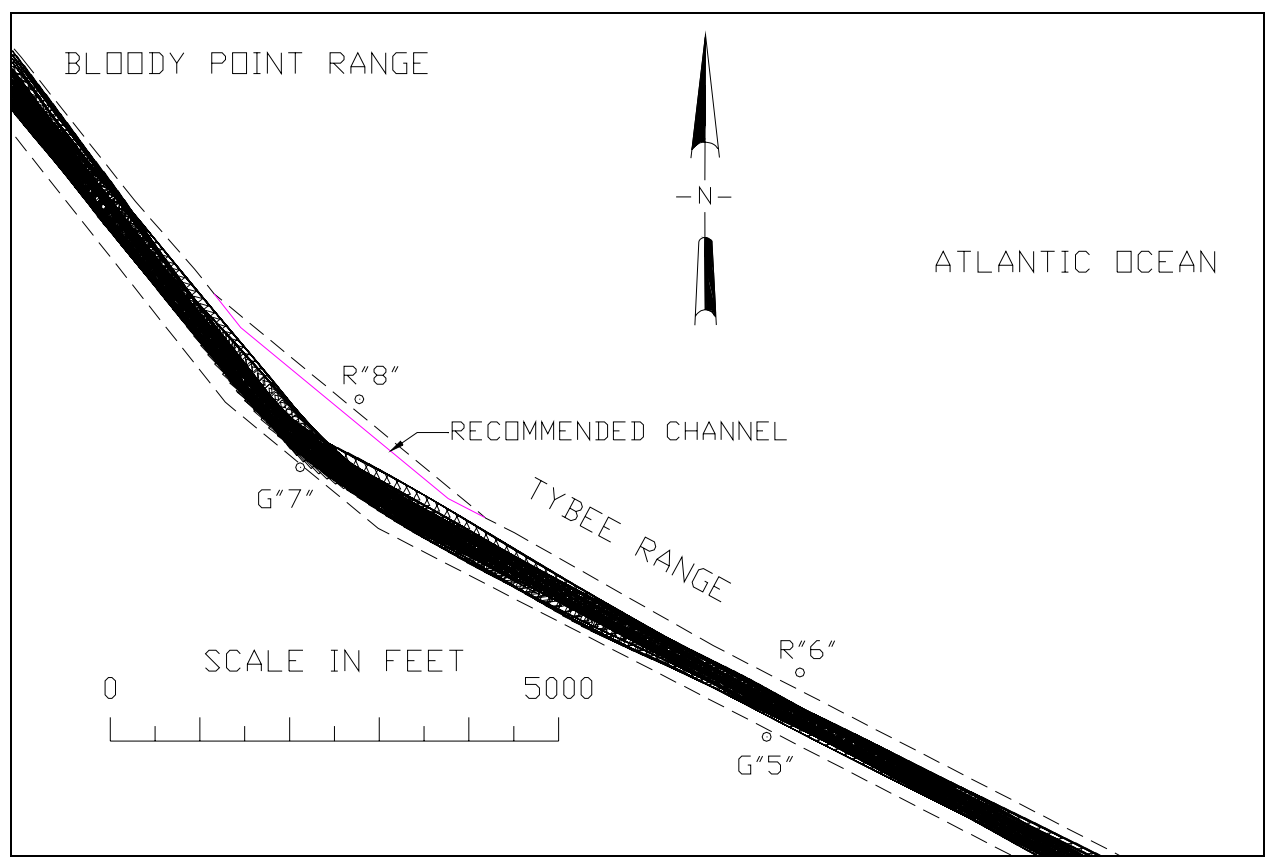

Figure 24. Recommended turn with tracks of all S-class containership simulations

The Bloody Point Range may be improved as per the Plan 1.

Plan 1 widened Jones Island Range on the south side. However, the simulated vessels showed a strong tendency to stay to the north side while making the turn 
between Tybee Knoll Cut Range and Bloody Point Range (Figure 25).

Therefore, it is recommended that the widening be shifted to the north side of Jones Island Range as shown in Figure 26.

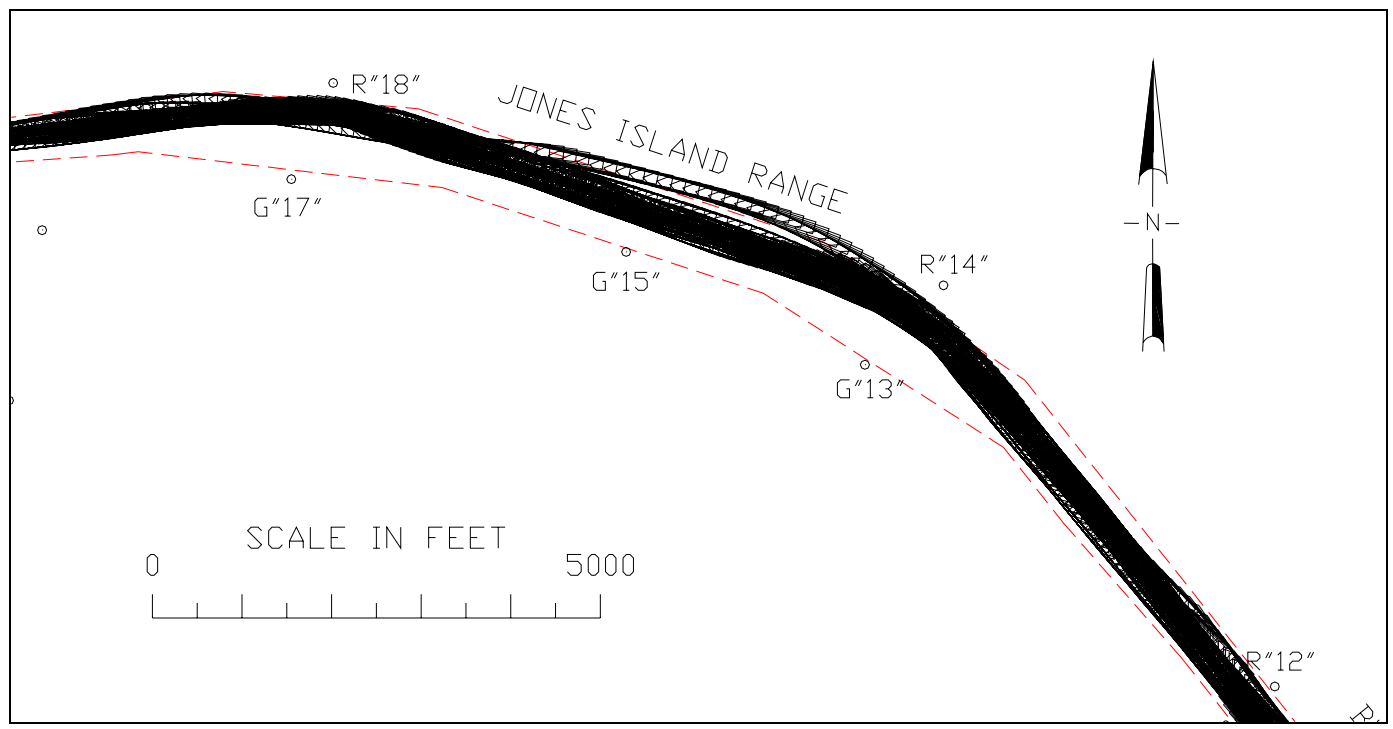

Figure 25. Jones Island Range, all S-class containership tracks

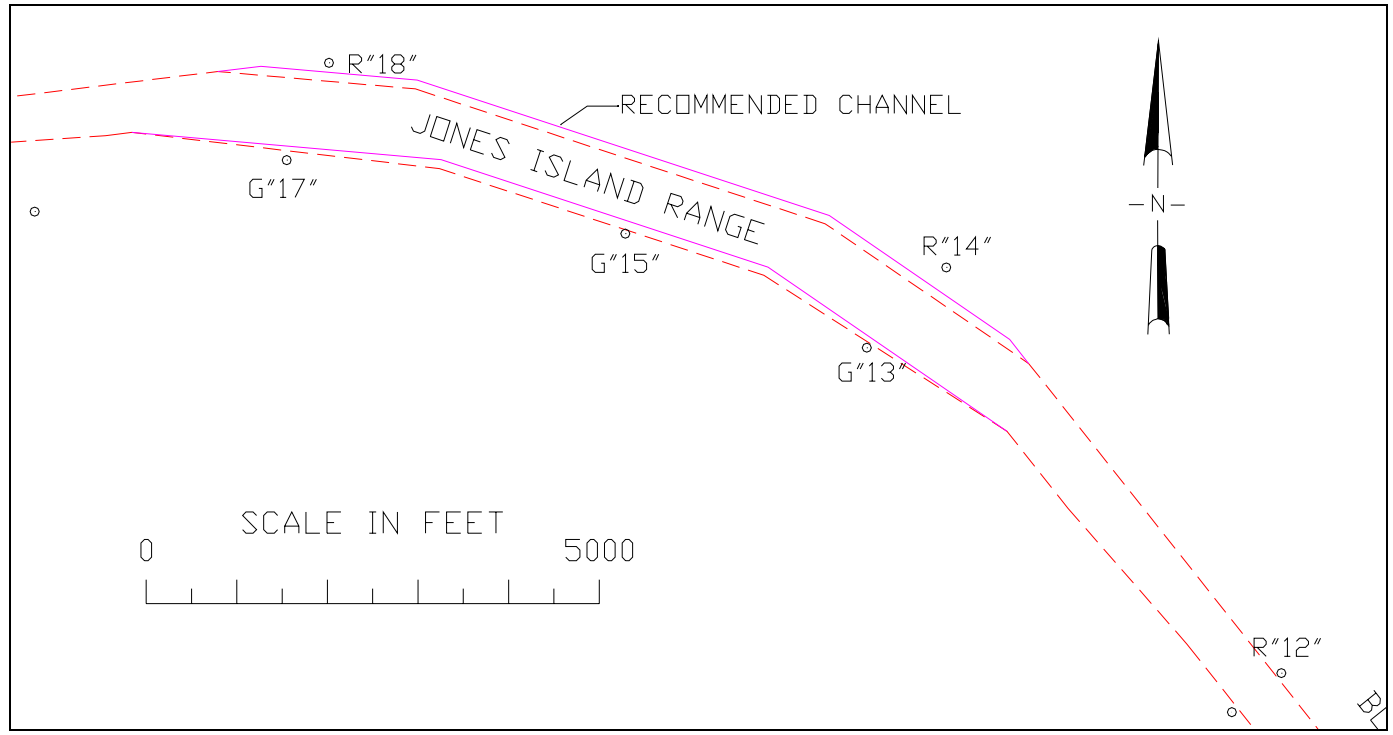

Figure 26. Recommended widener for Jones Island Range

The Tybee Knoll Cut Range and the New Channel Range may be deepened to $48 \mathrm{ft}$ on their existing side slopes as simulated for Plan 1 conditions.

The wider Plan 2 channel is recommended for the Long Island Range. This is a long reach, fairly centrally located in the project. Providing the extra width will provide an excellent area for meeting of extremely large ships. 
The Plan 1 channel is recommended for the Lower Flats Range. The pilots did not use the widenings on the west side of the turn between Lower and Upper Flats Ranges (previously shown in Figure 20) or on the west side of the Upper Flats Range or on the south side of The Bight Channel. Therefore, the $48-\mathrm{ft}$ channel can be deepened on its existing side slopes in this area (Figure 27). Ships tended to stay to the north side of The Bight Channel. It is recommended that this area not be deepened on the existing side slopes, but be deepened on the existing limits.

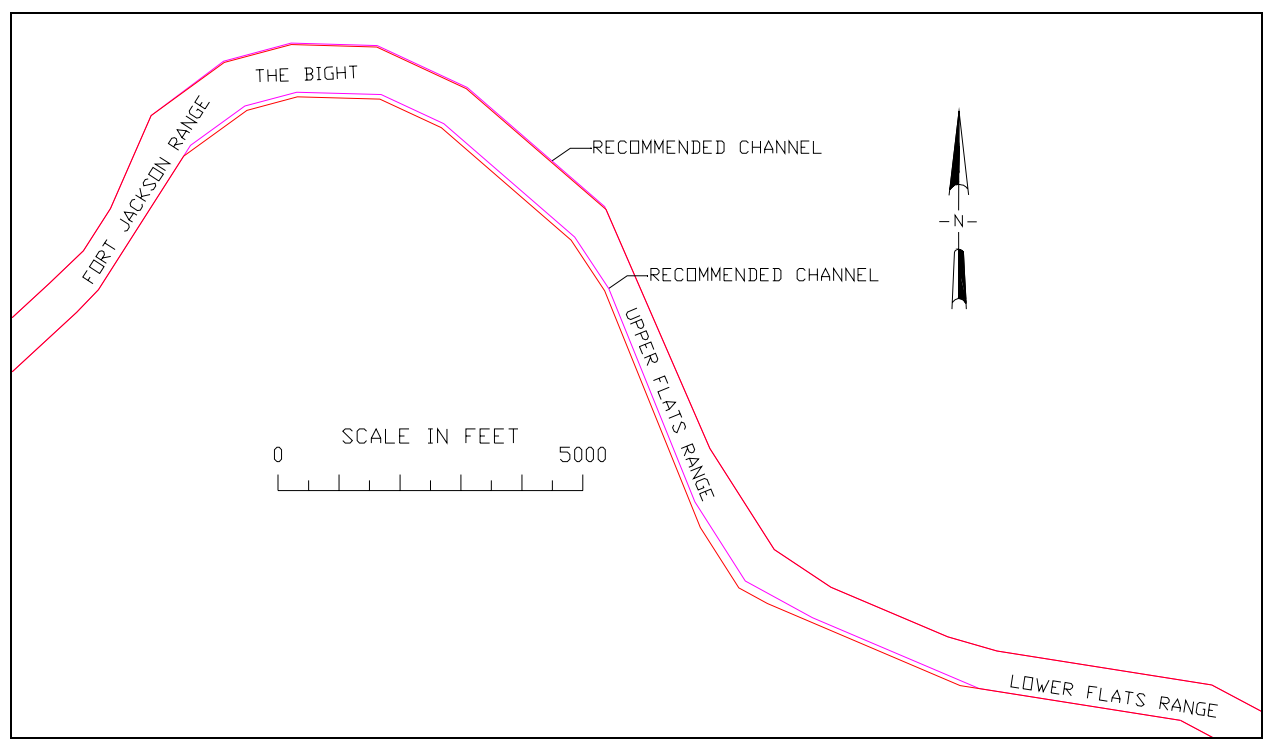

Figure 27. Channel recommendations Lower Flats Range through The Bight Channel

The Plan 2 channel is recommended for Fort Jackson Range. The additional $100 \mathrm{ft}$ will provide a safe passing zone that the pilots can use with confidence. The pilots consistently relied upon the additional width for two-way traffic during the simulations. Fort Jackson Range is long enough that the pilots can easily coordinate meeting there if necessary.

Because of the ships' tendency to leave the channel a bit on the north side, it is recommended that the north side of Oglethorpe Range and Wrecks Channel not be deepened along the existing side slope but be deepened on the existing limits.

None of the wideners on the Wrecks Channel/City Front Channel area were used. They may be omitted from the 48 -ft project.

The proposed 1,650-ft-diam Kings Island Turning Basin is adequate for turning the Susan Maersk. It is recommended that the basin be dredged as proposed. 


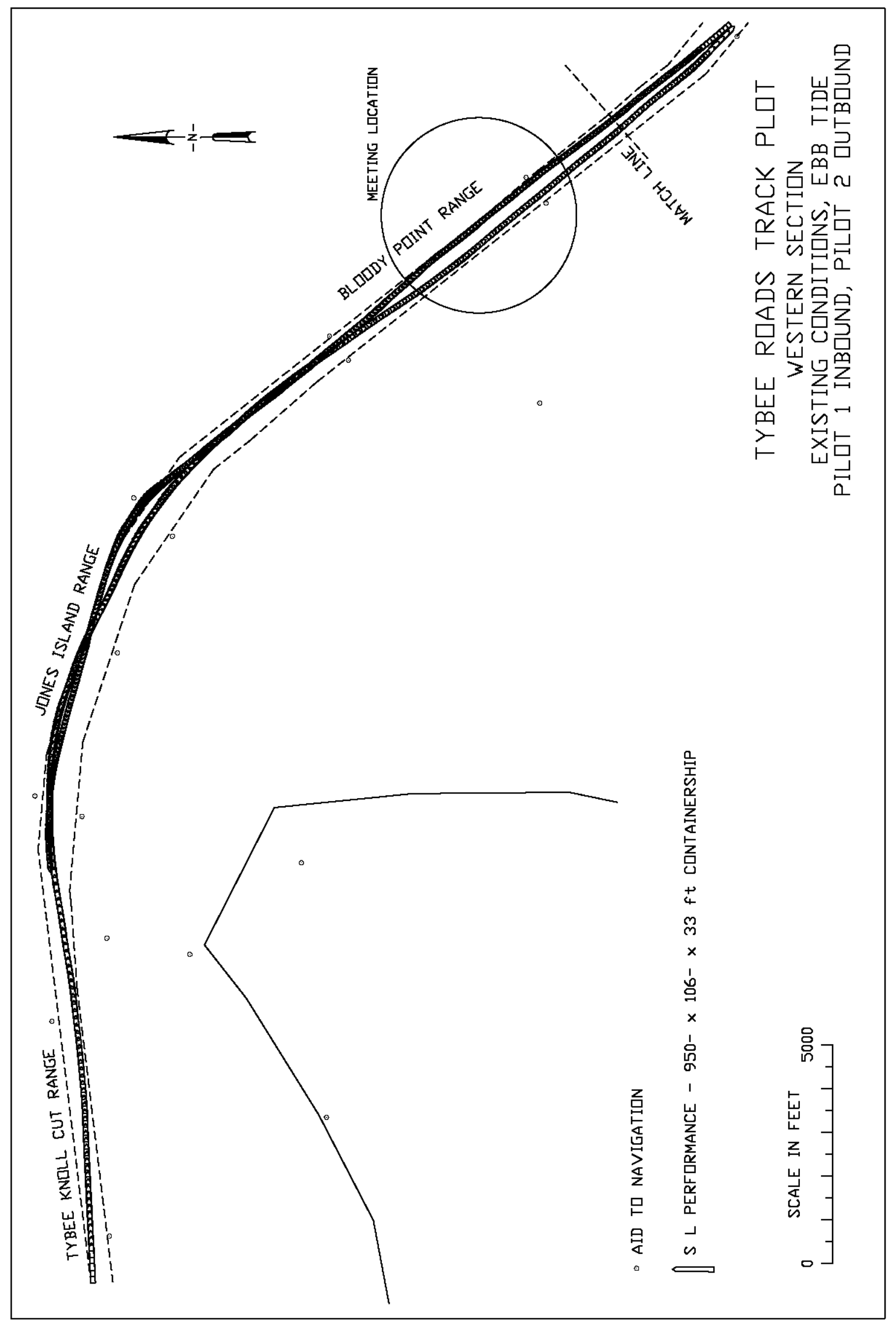

PLATE 1 

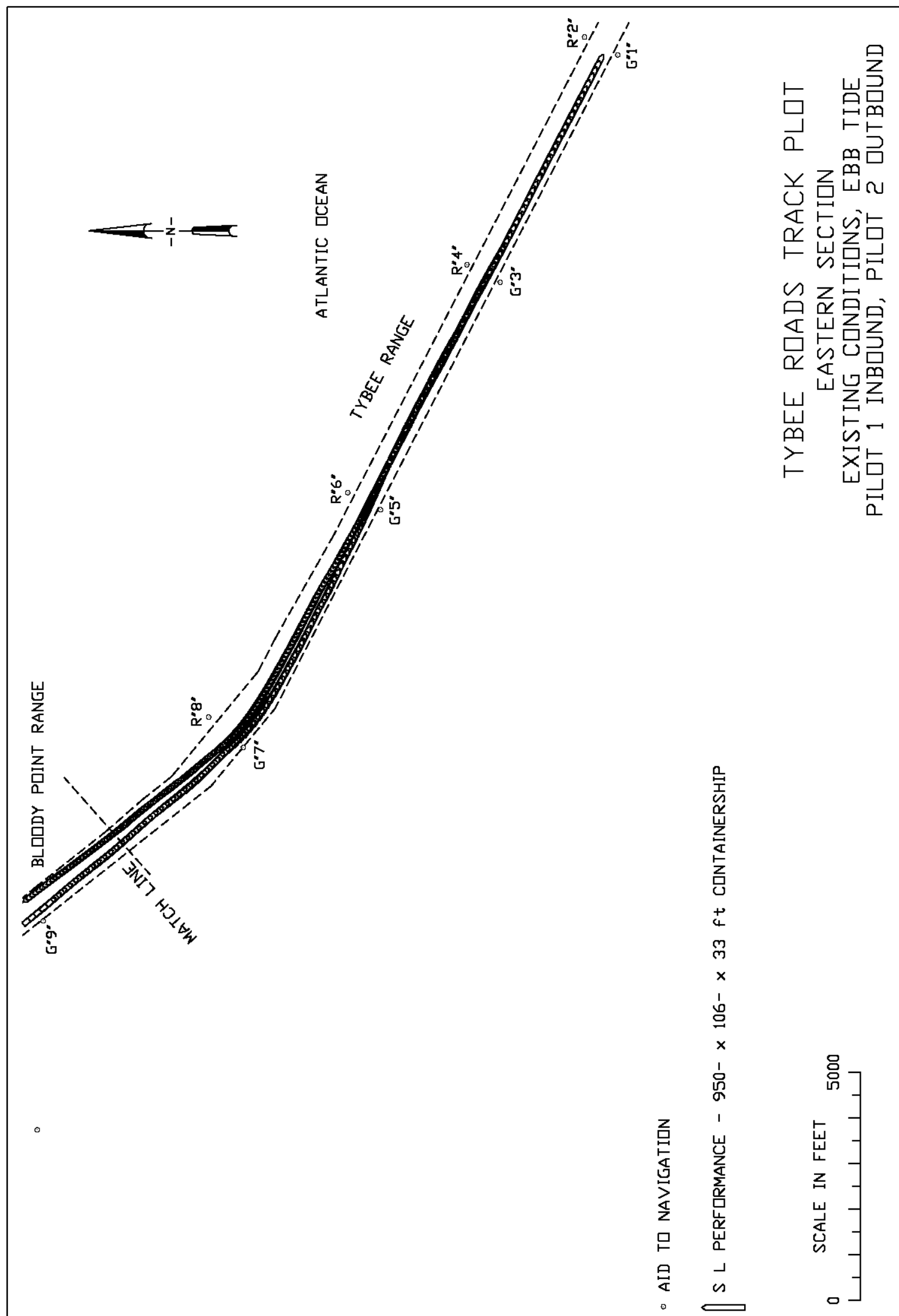

PLATE ? 


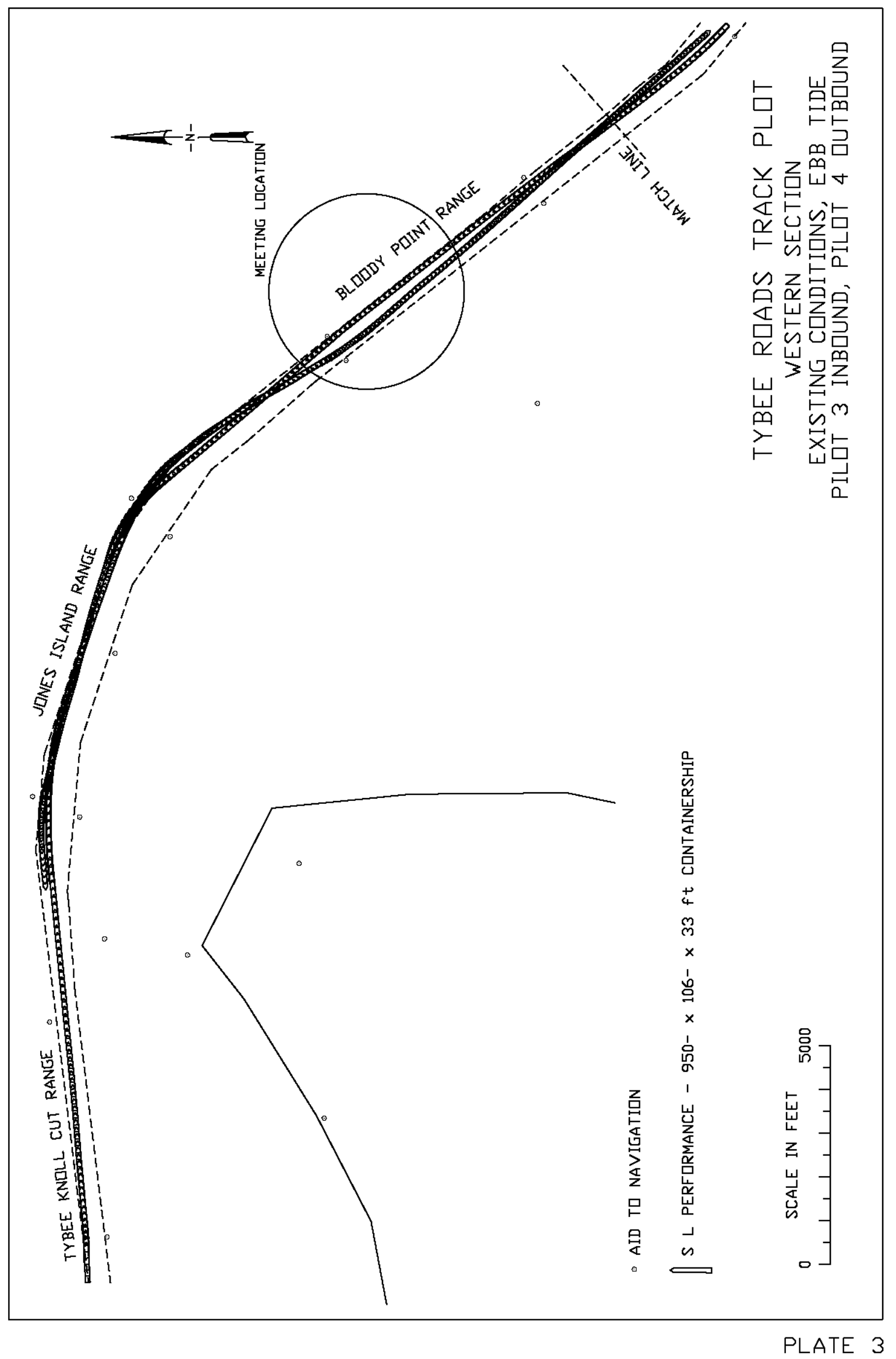




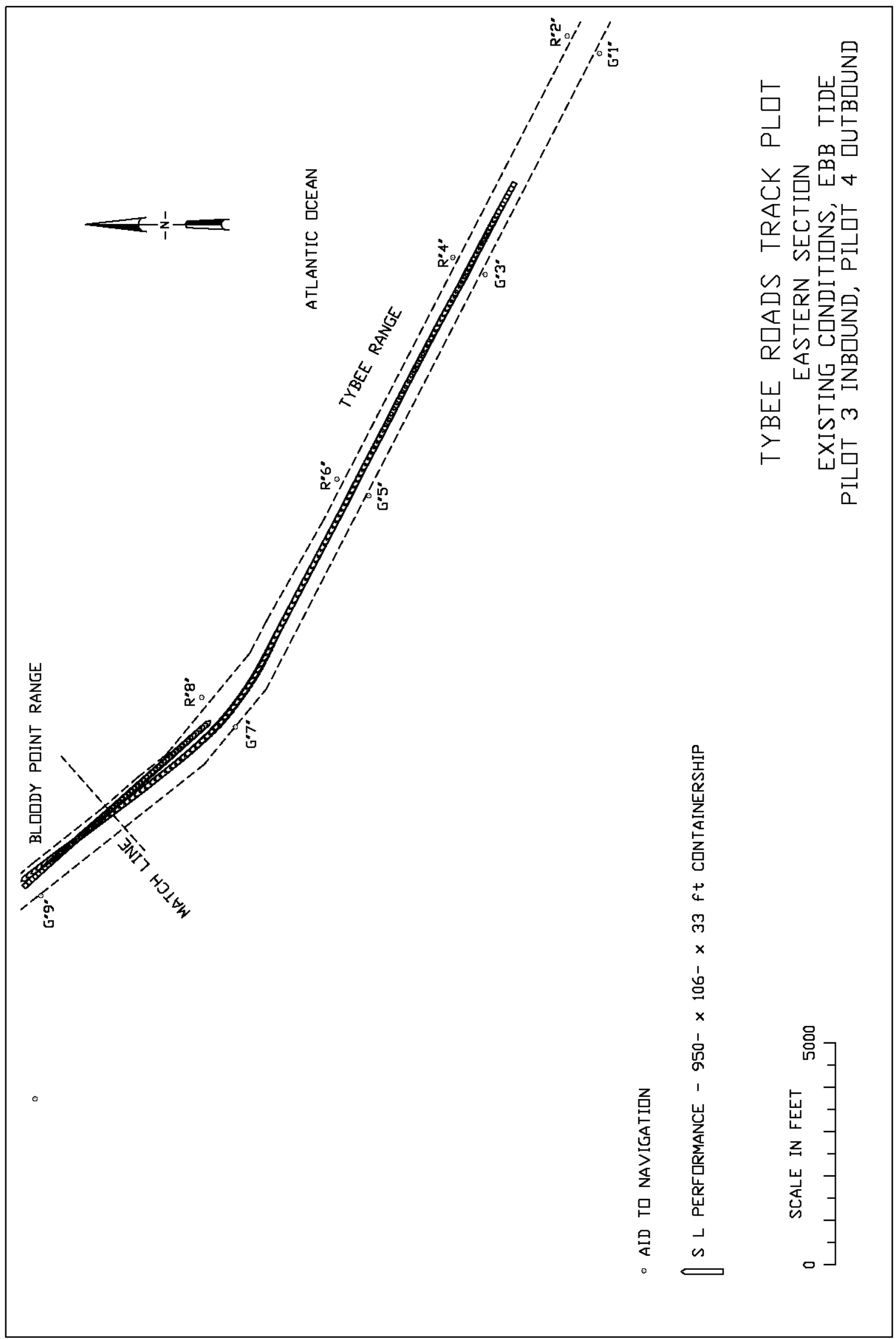

PLATE 4 


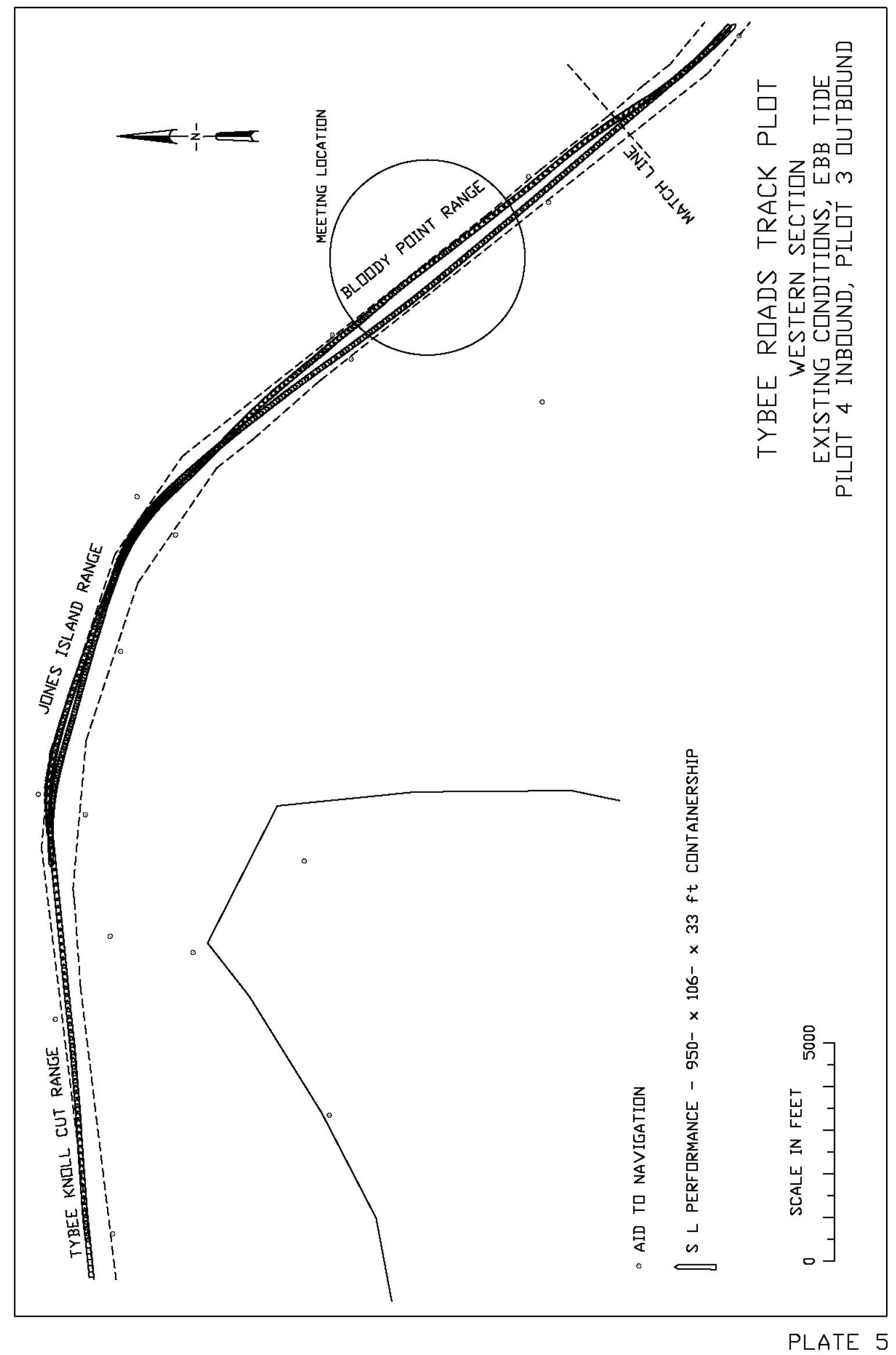




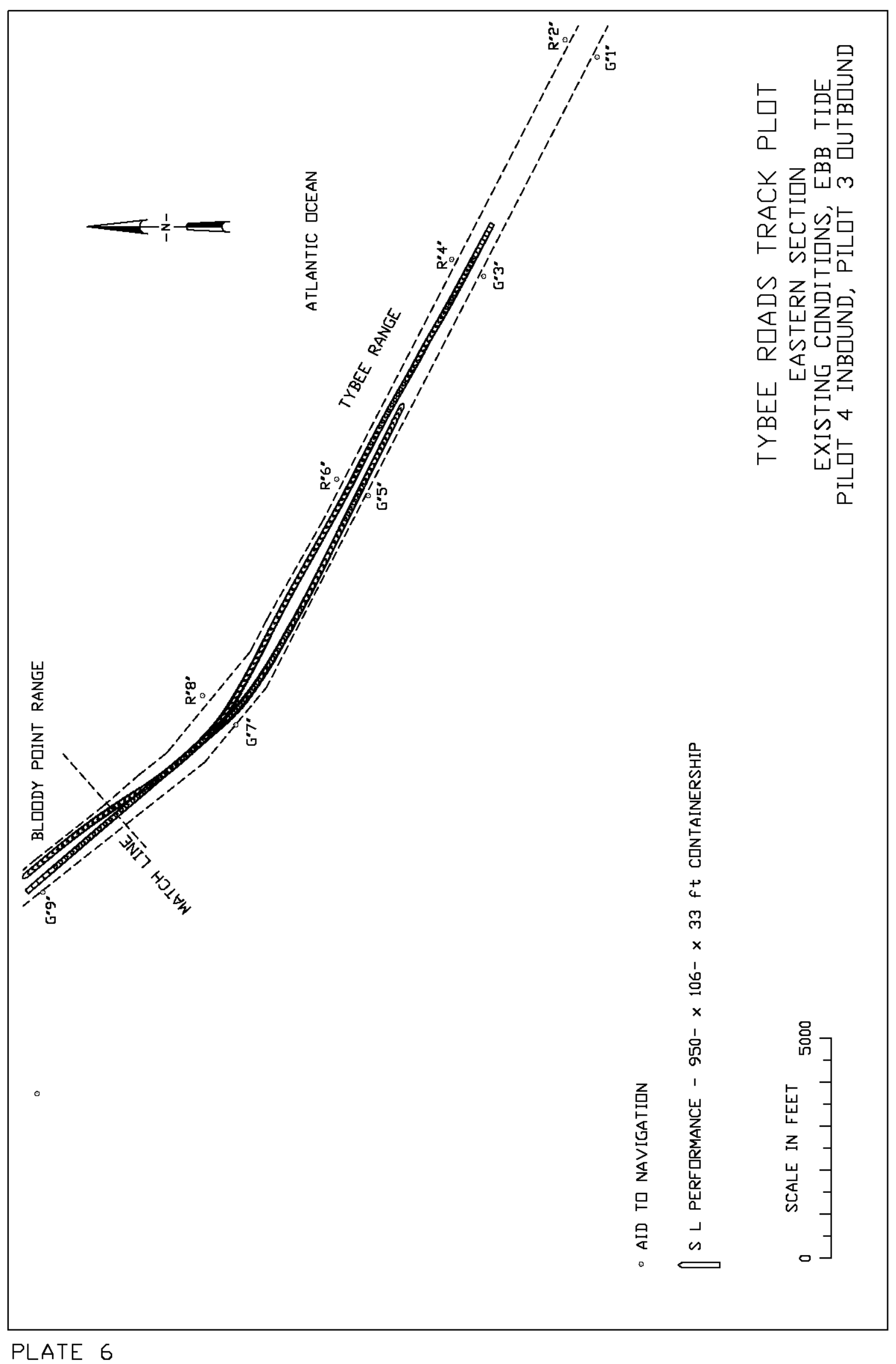




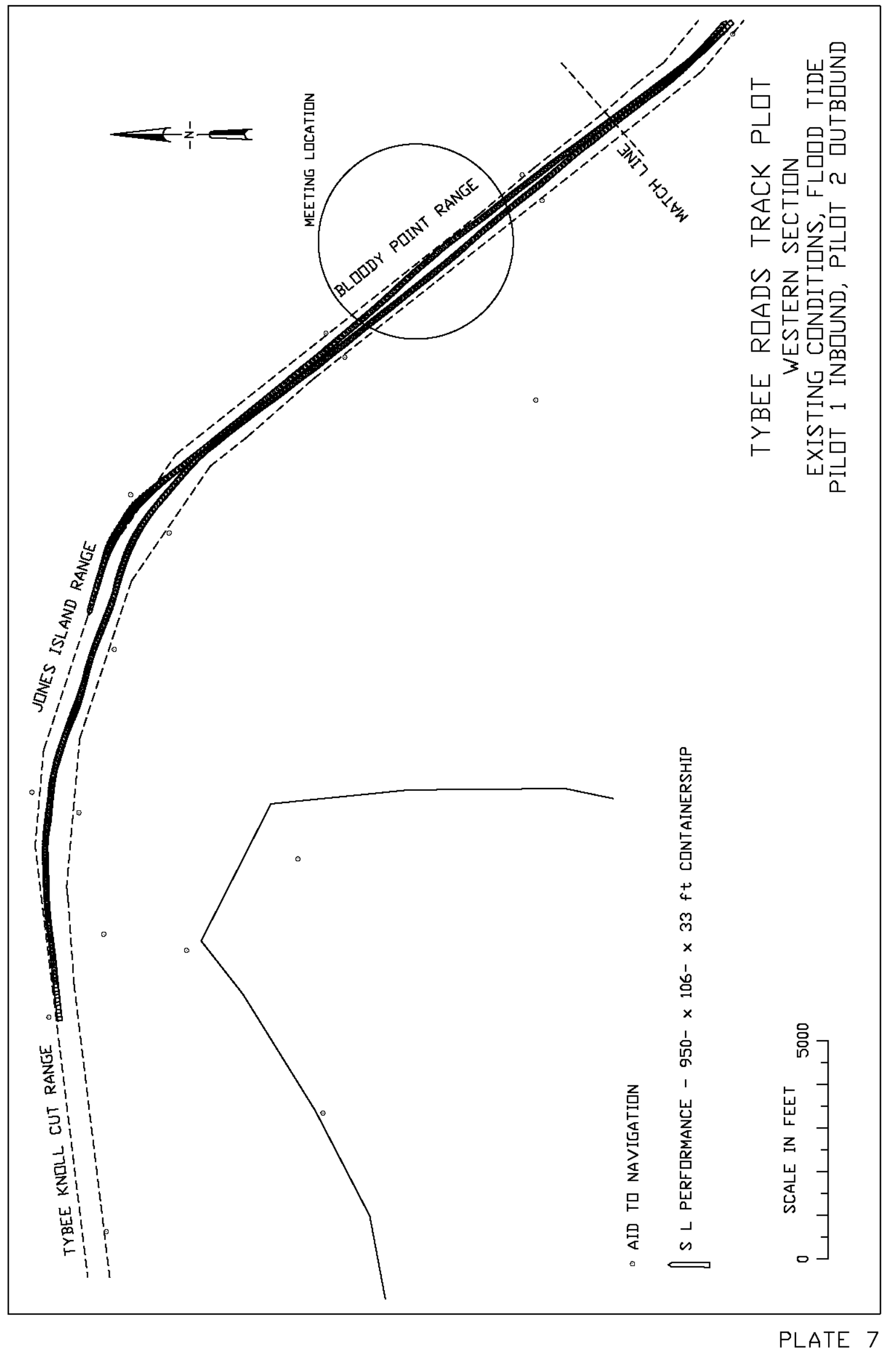




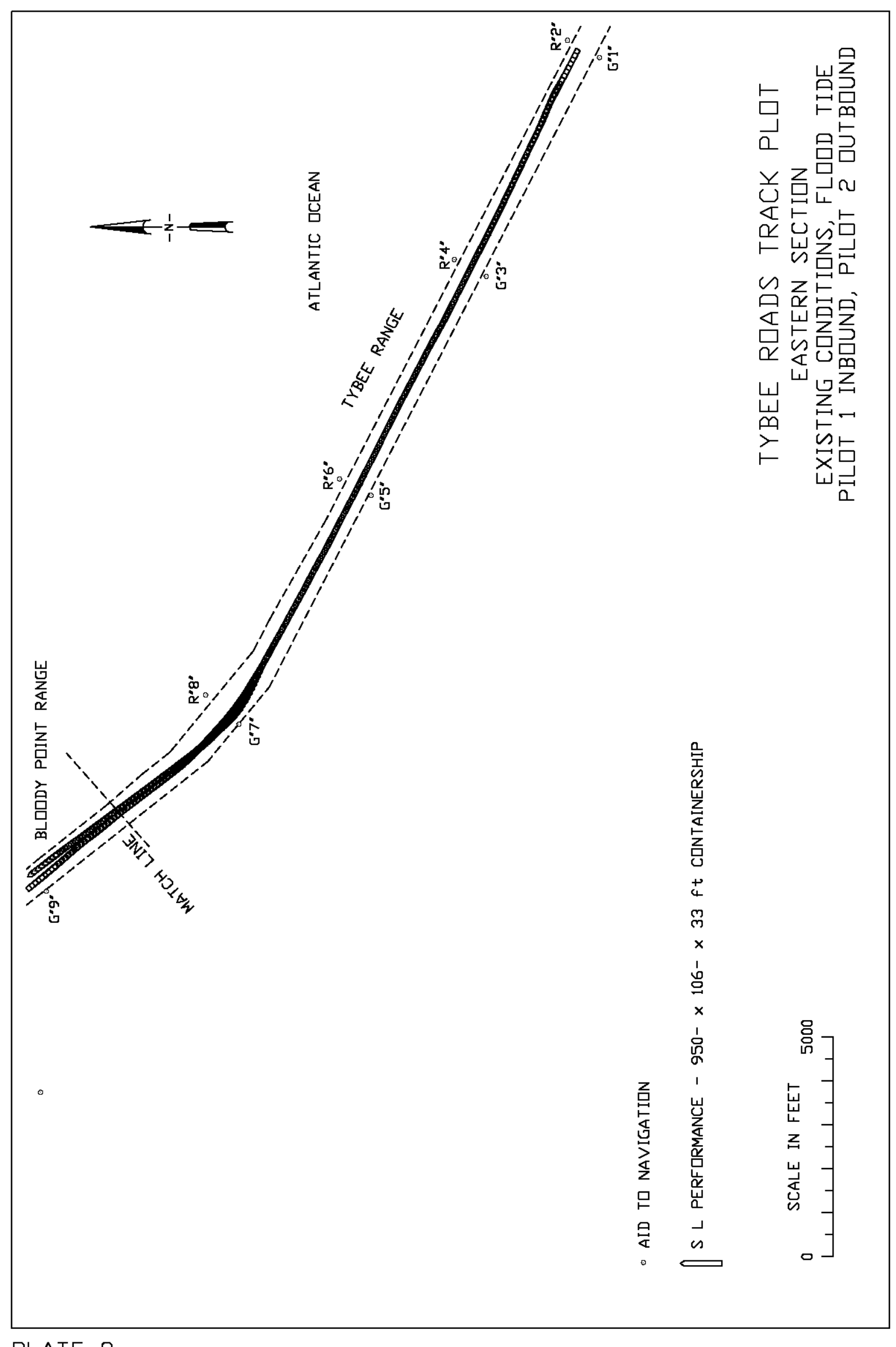

PLATE 8 


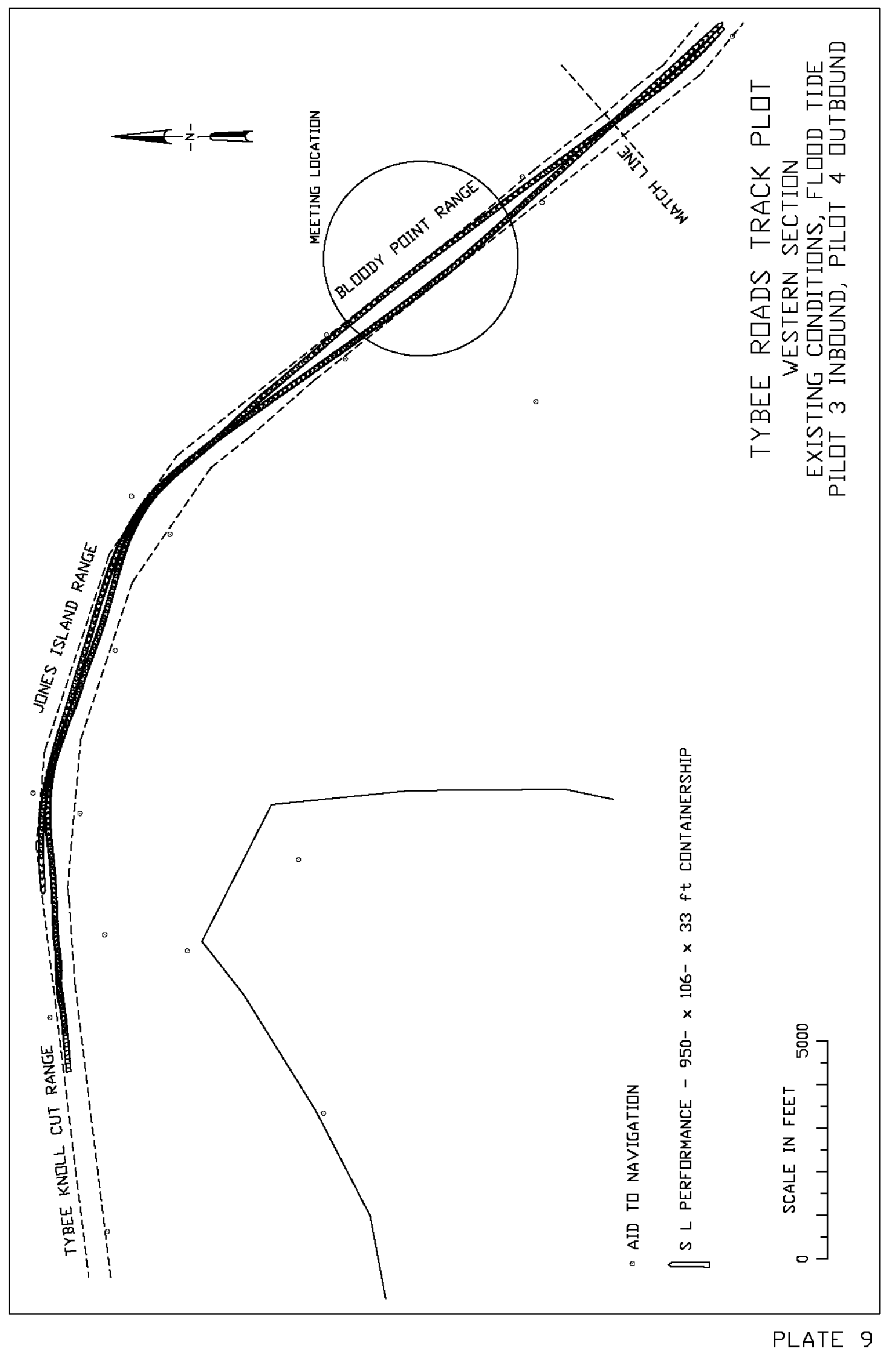




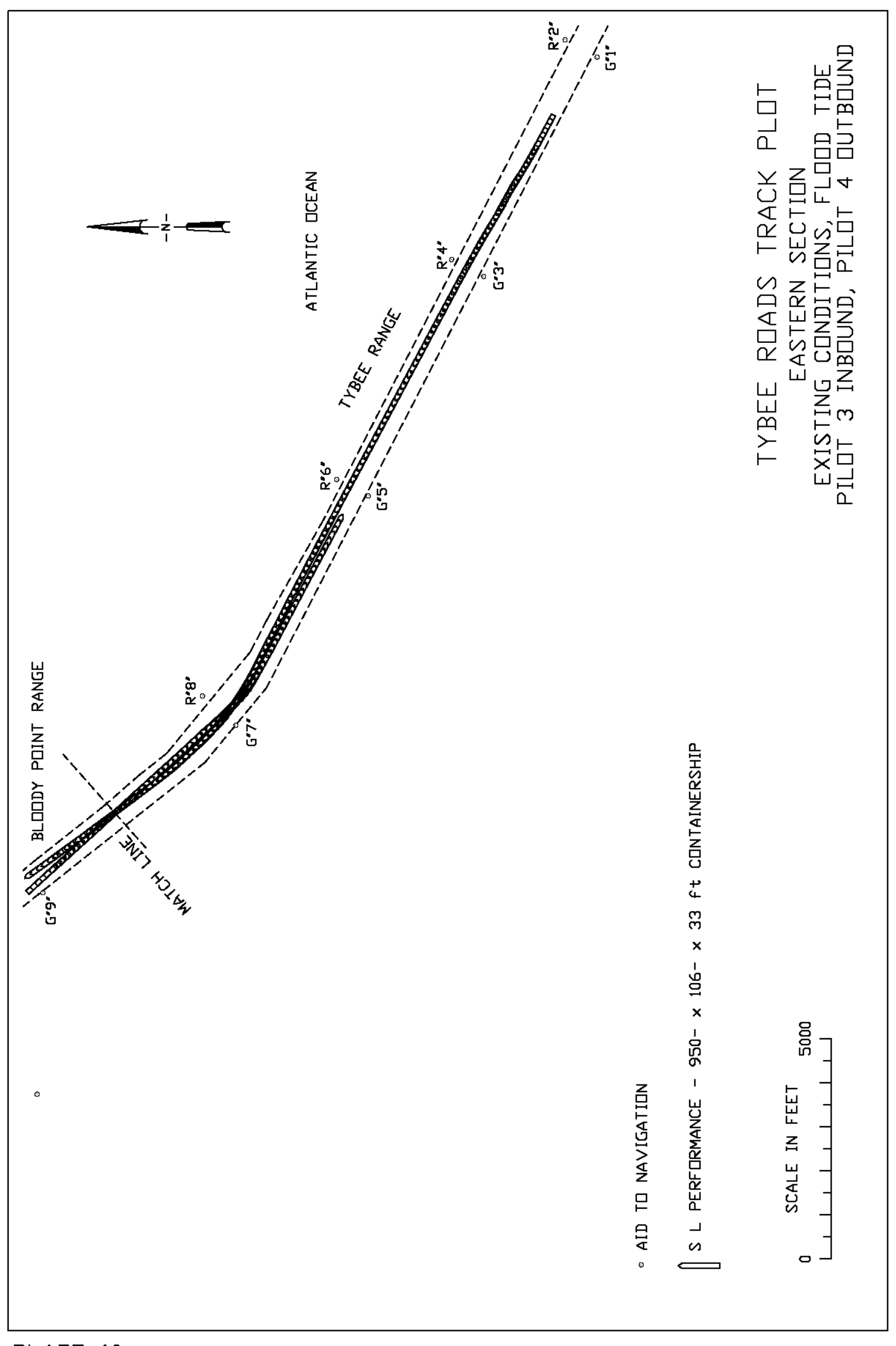

PLATE 10 


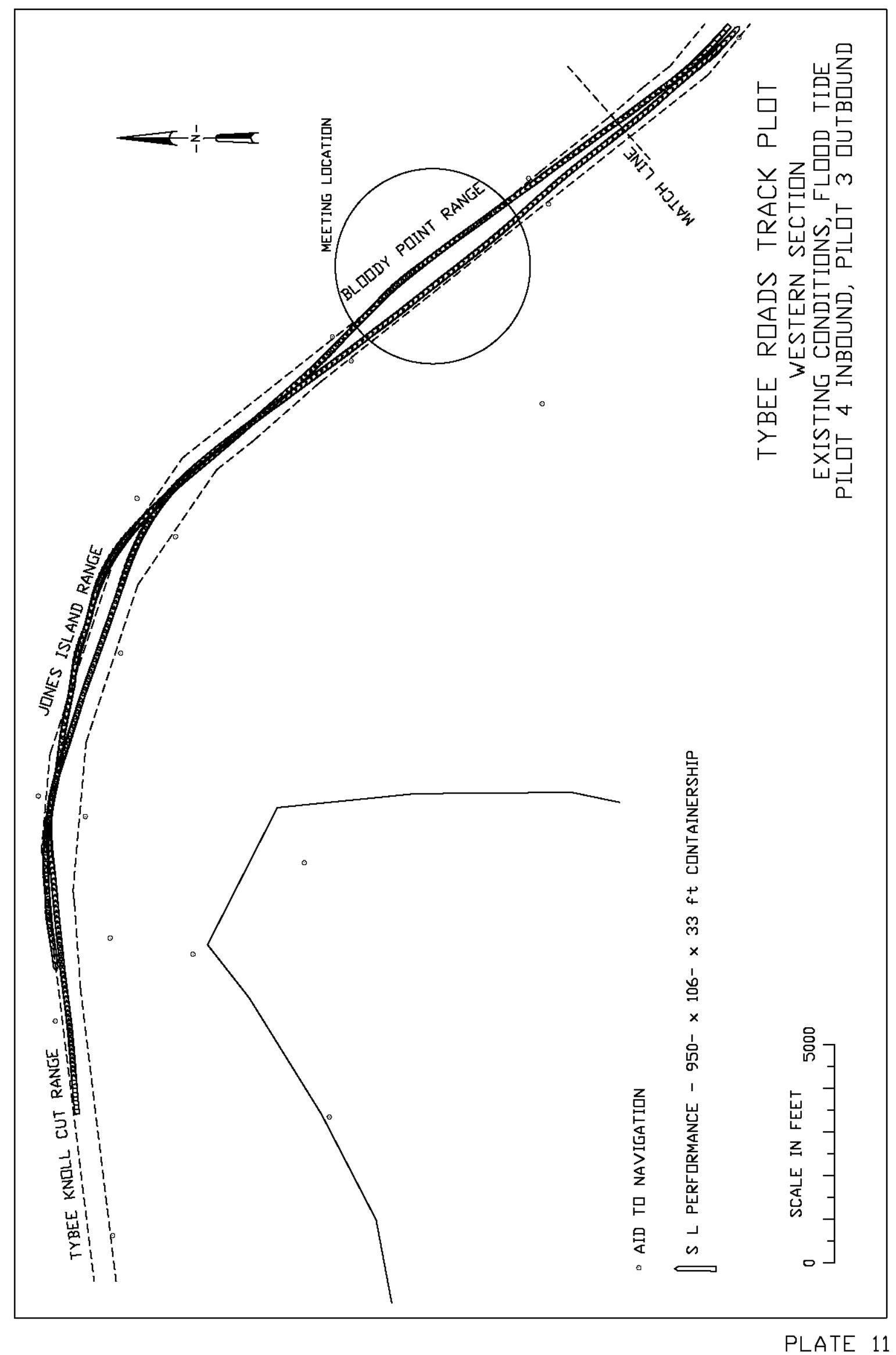




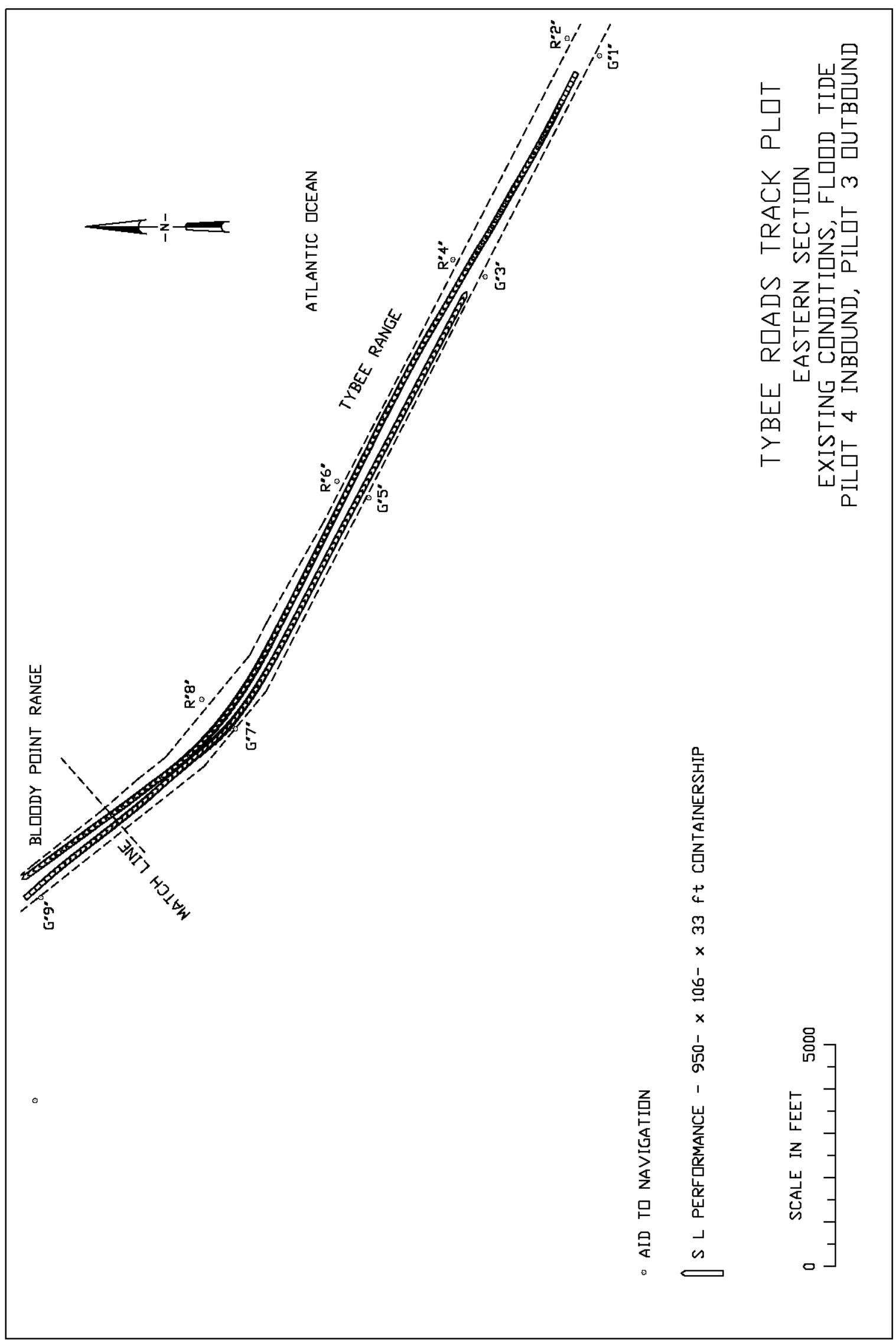

PLATE 12 


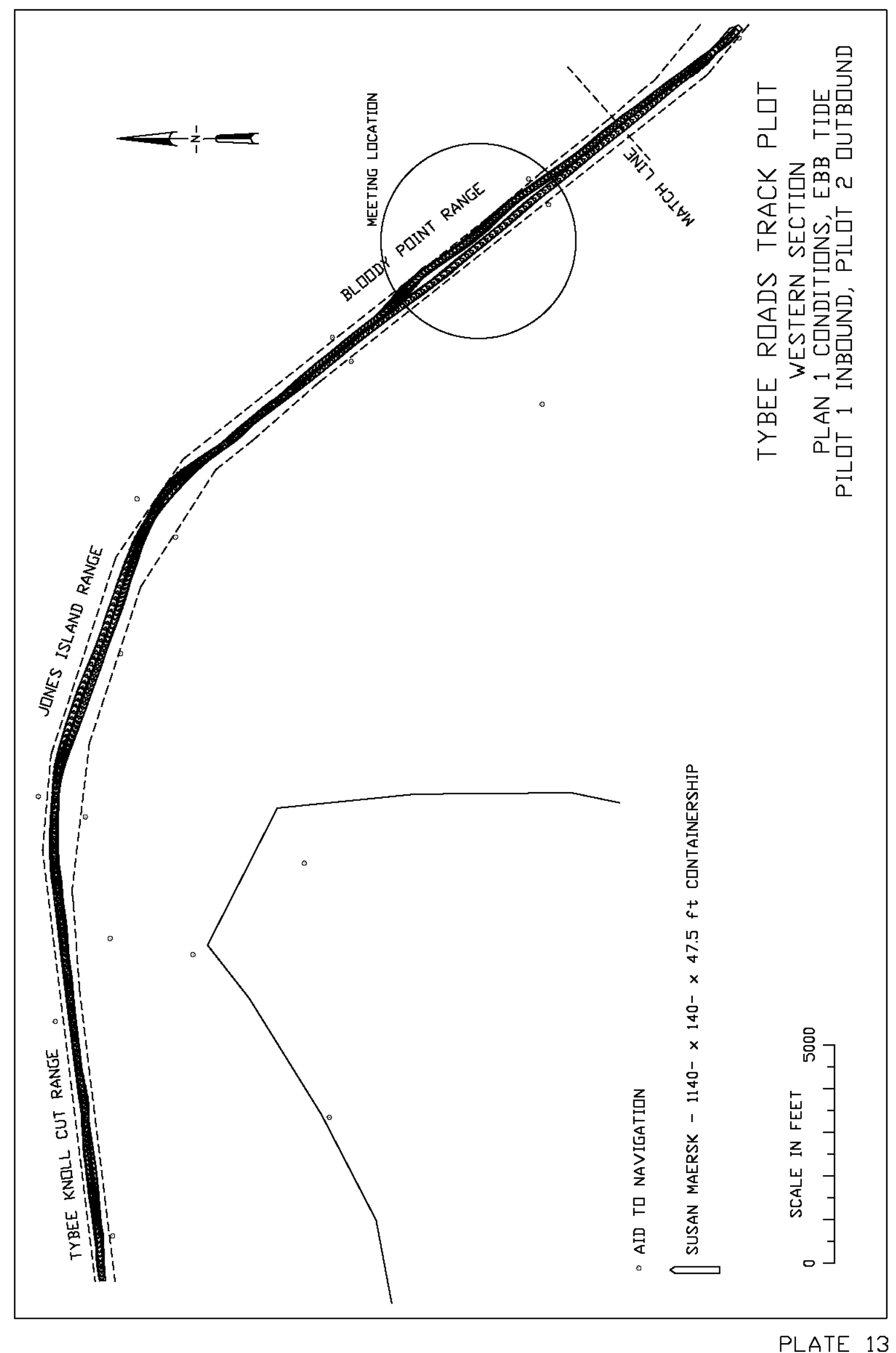




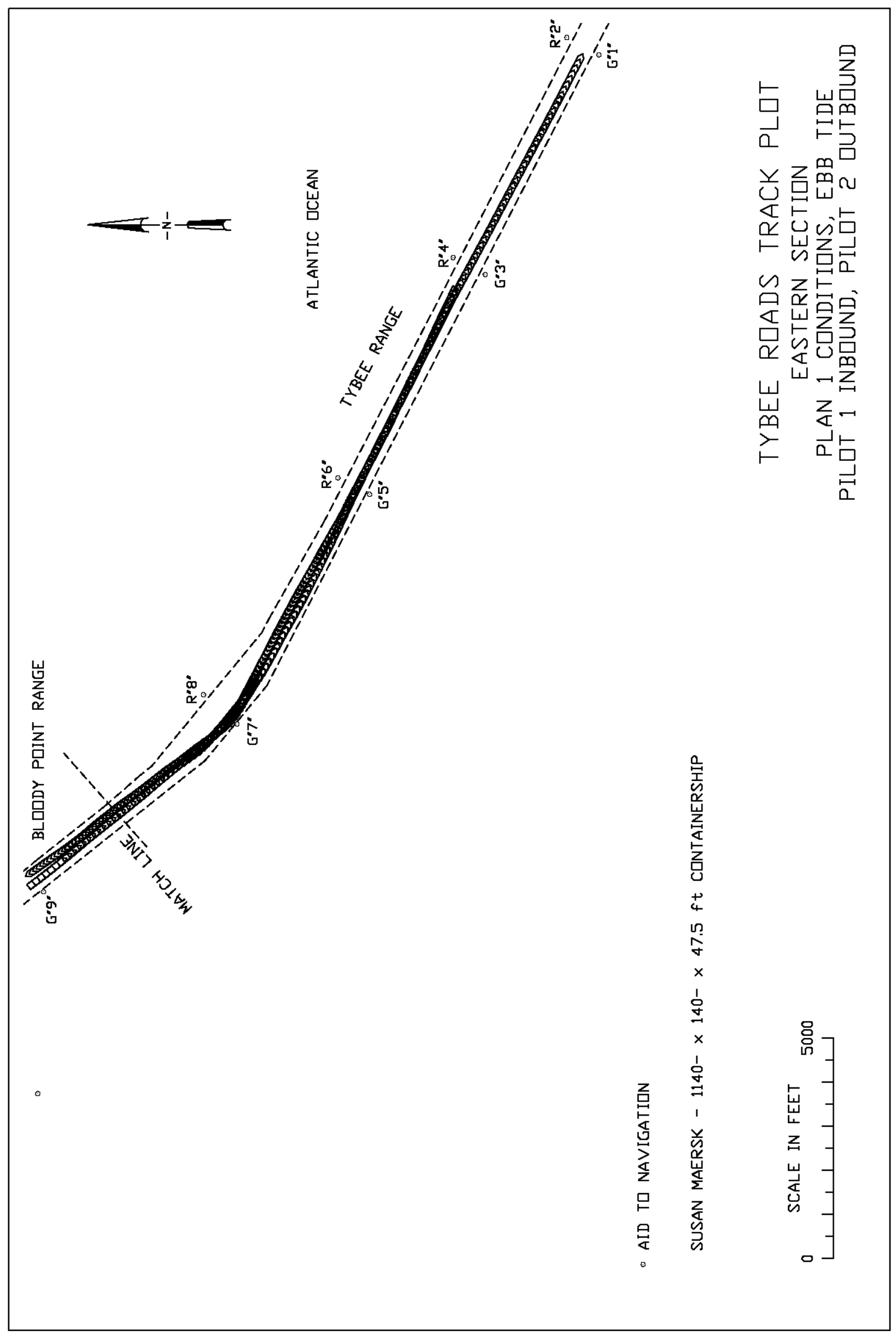

PLATE 14 


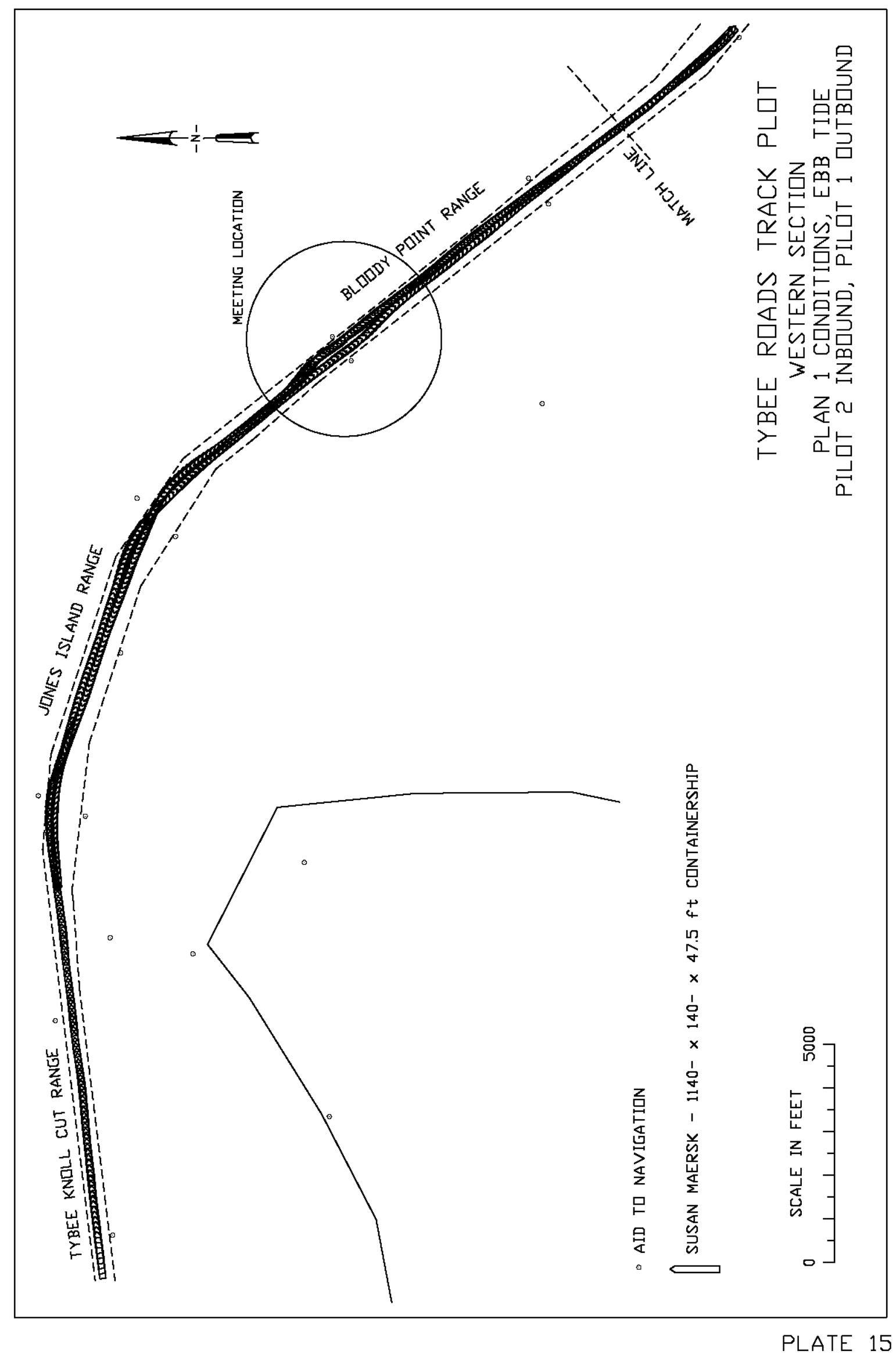




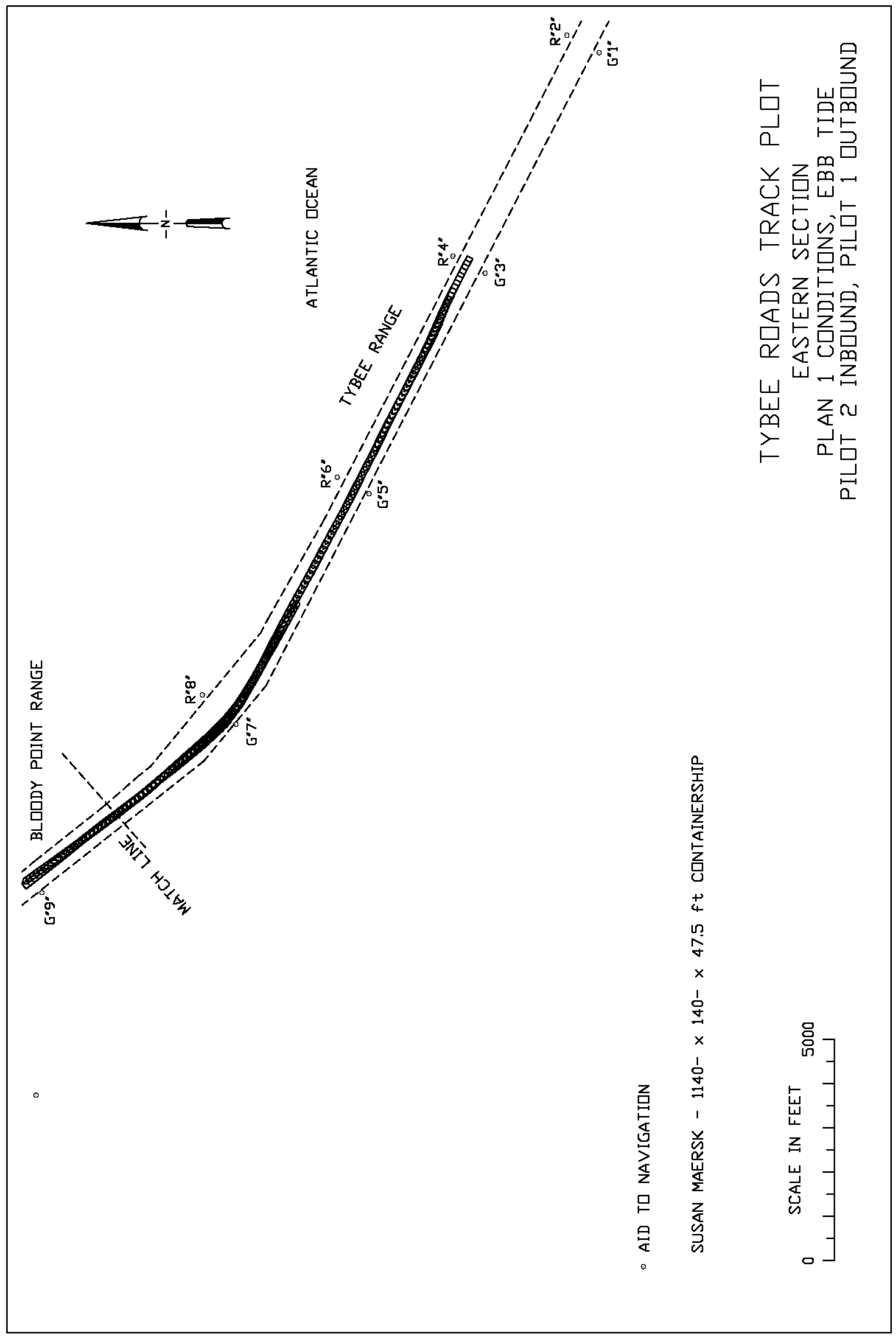

PLATE 16 


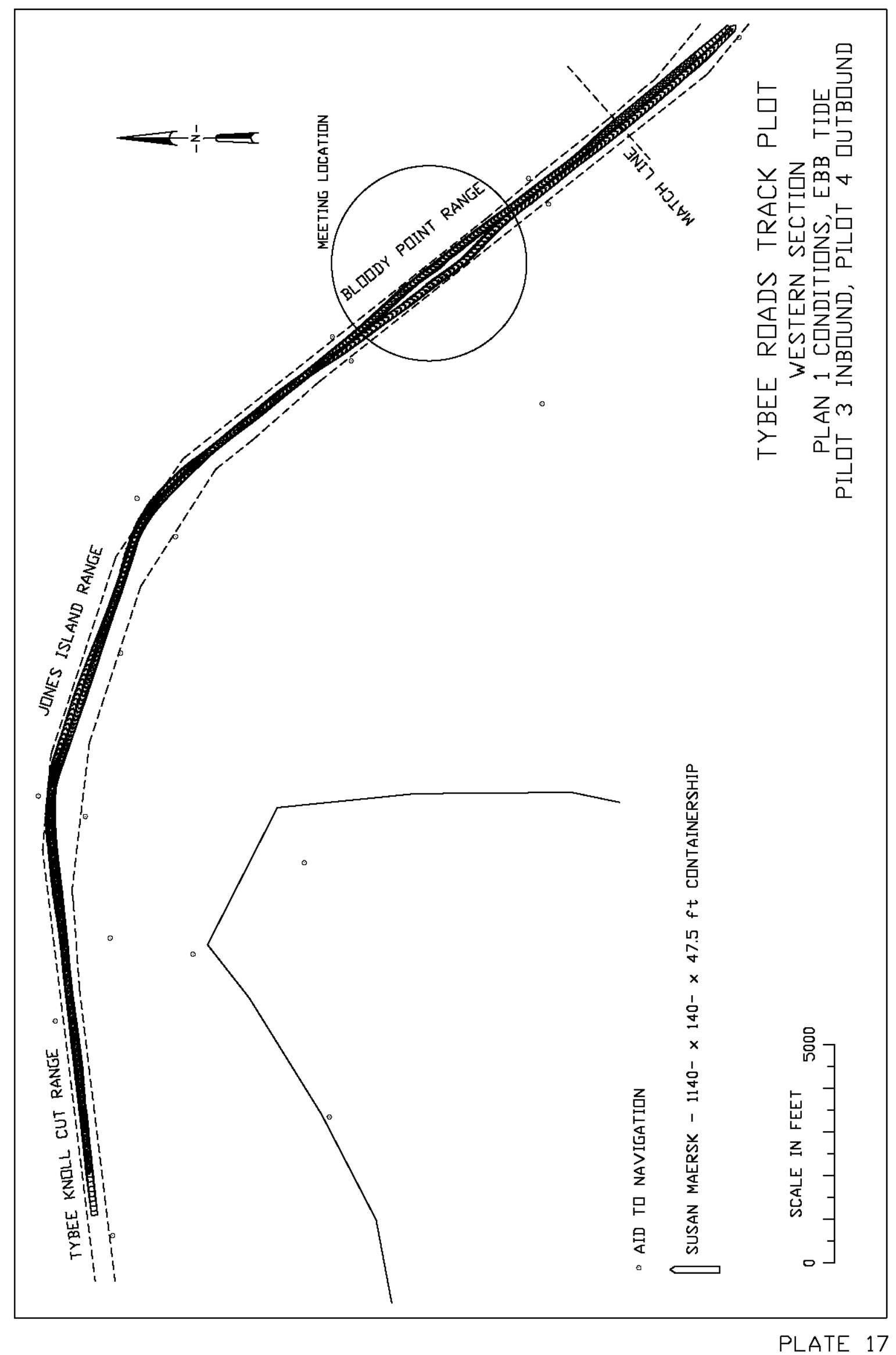




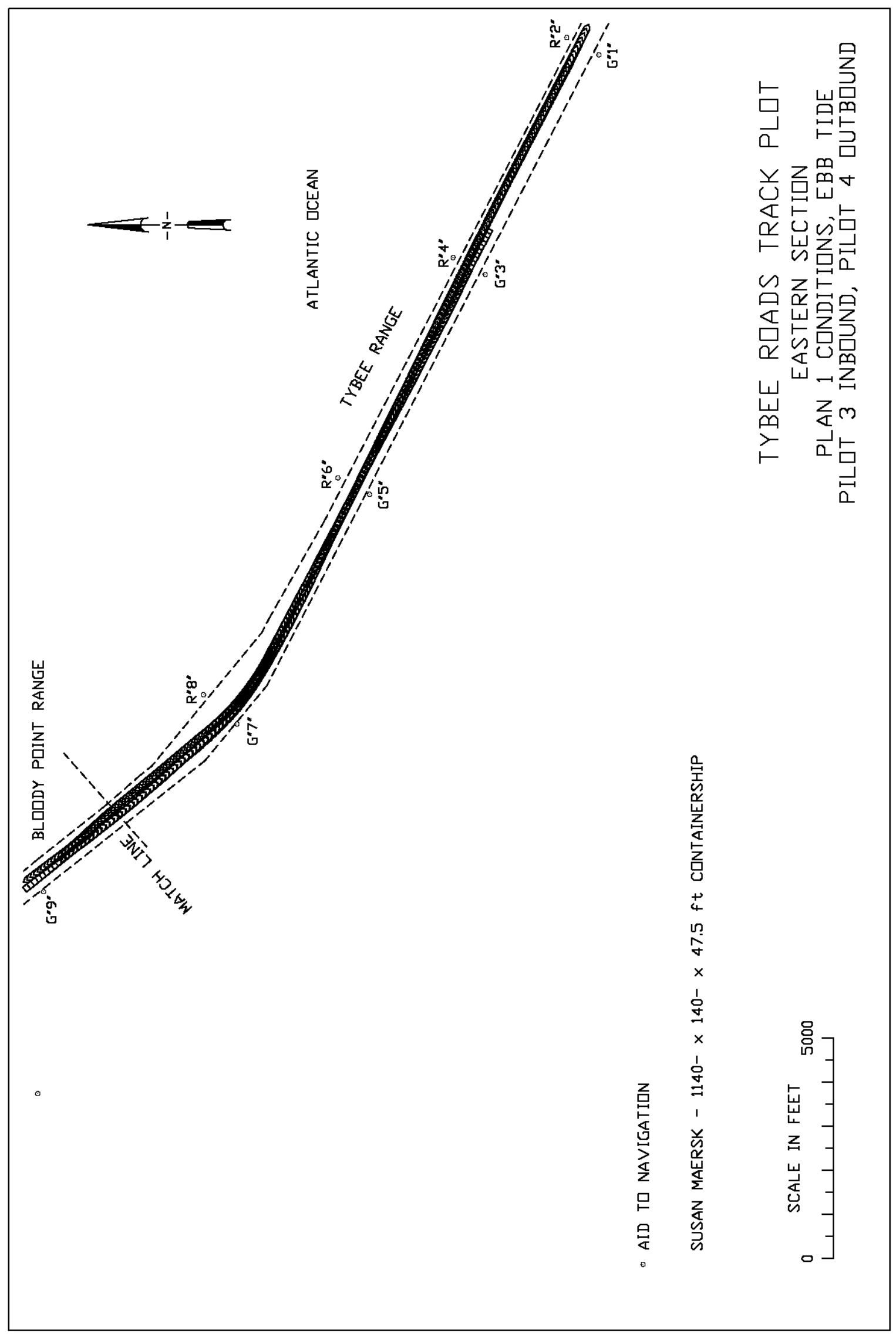

PLATE 18 


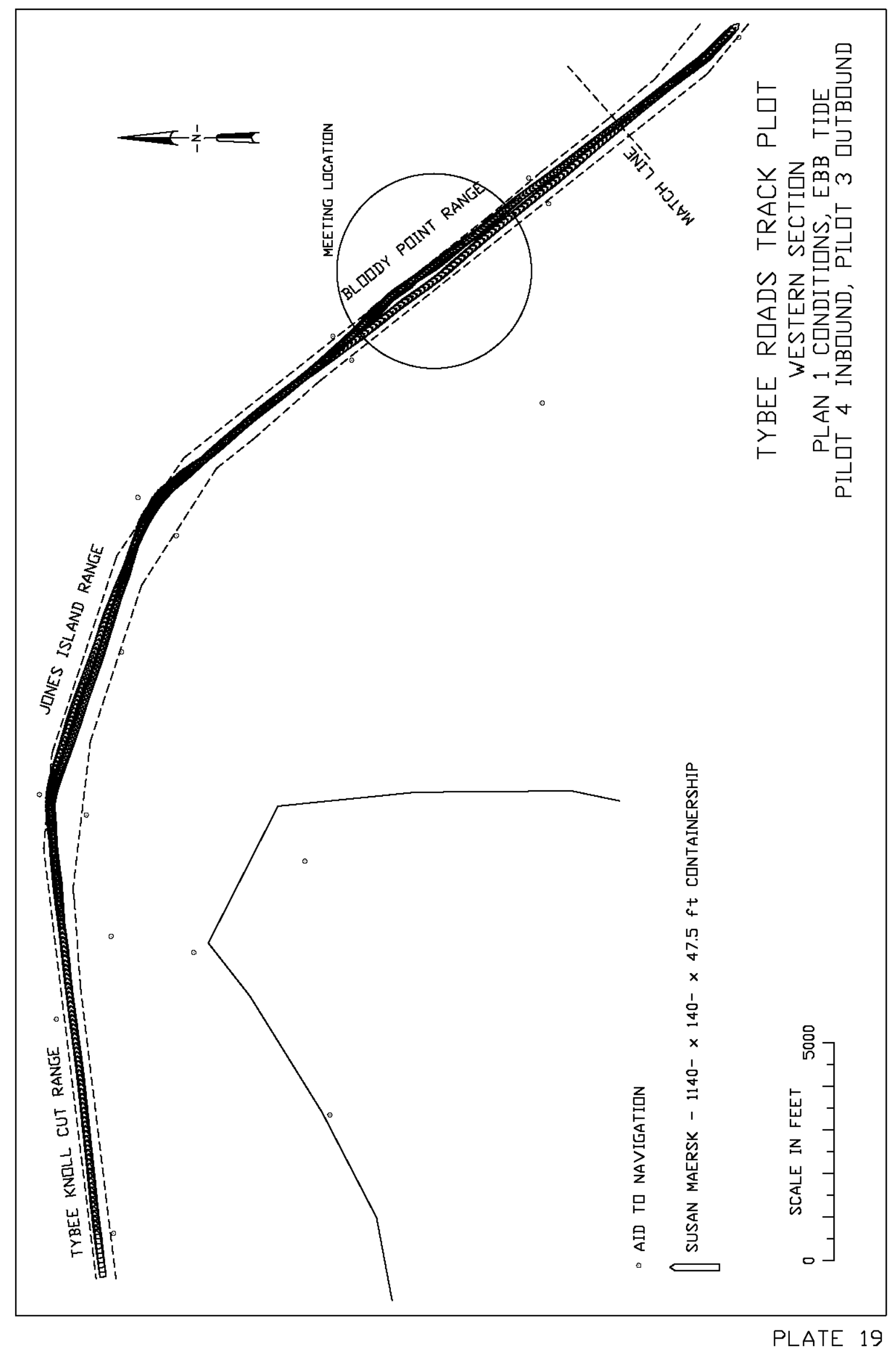




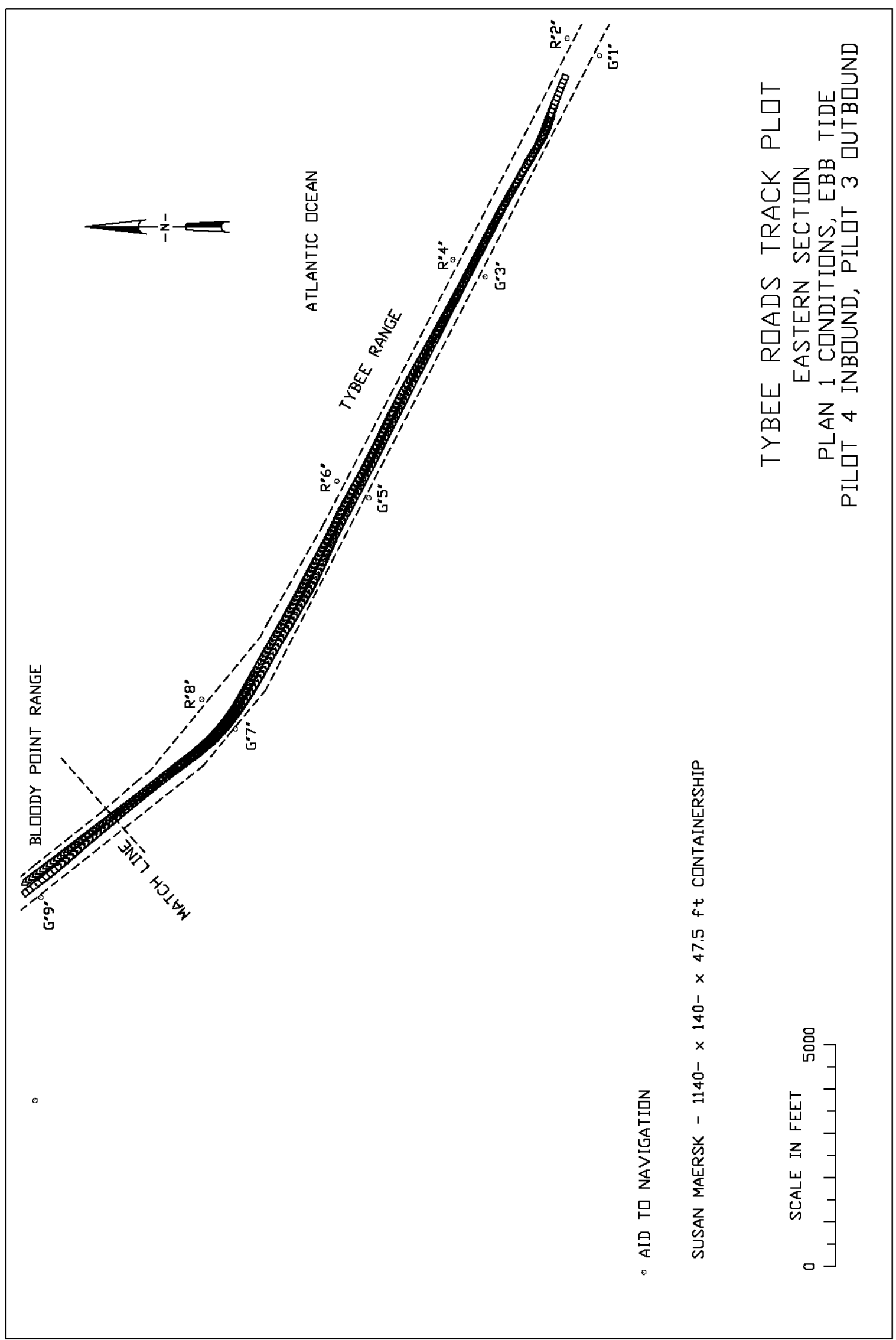

PLATE 20 


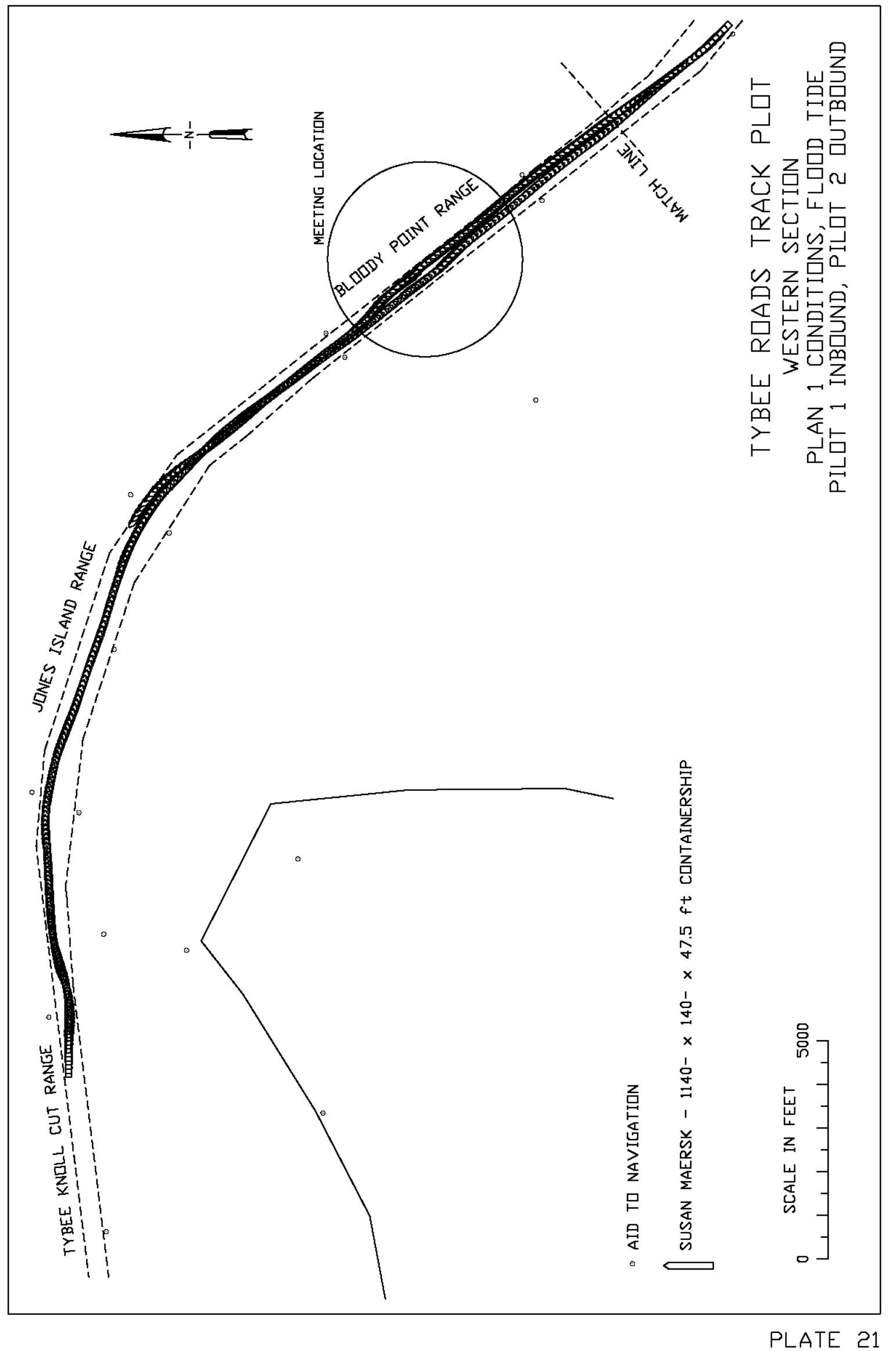




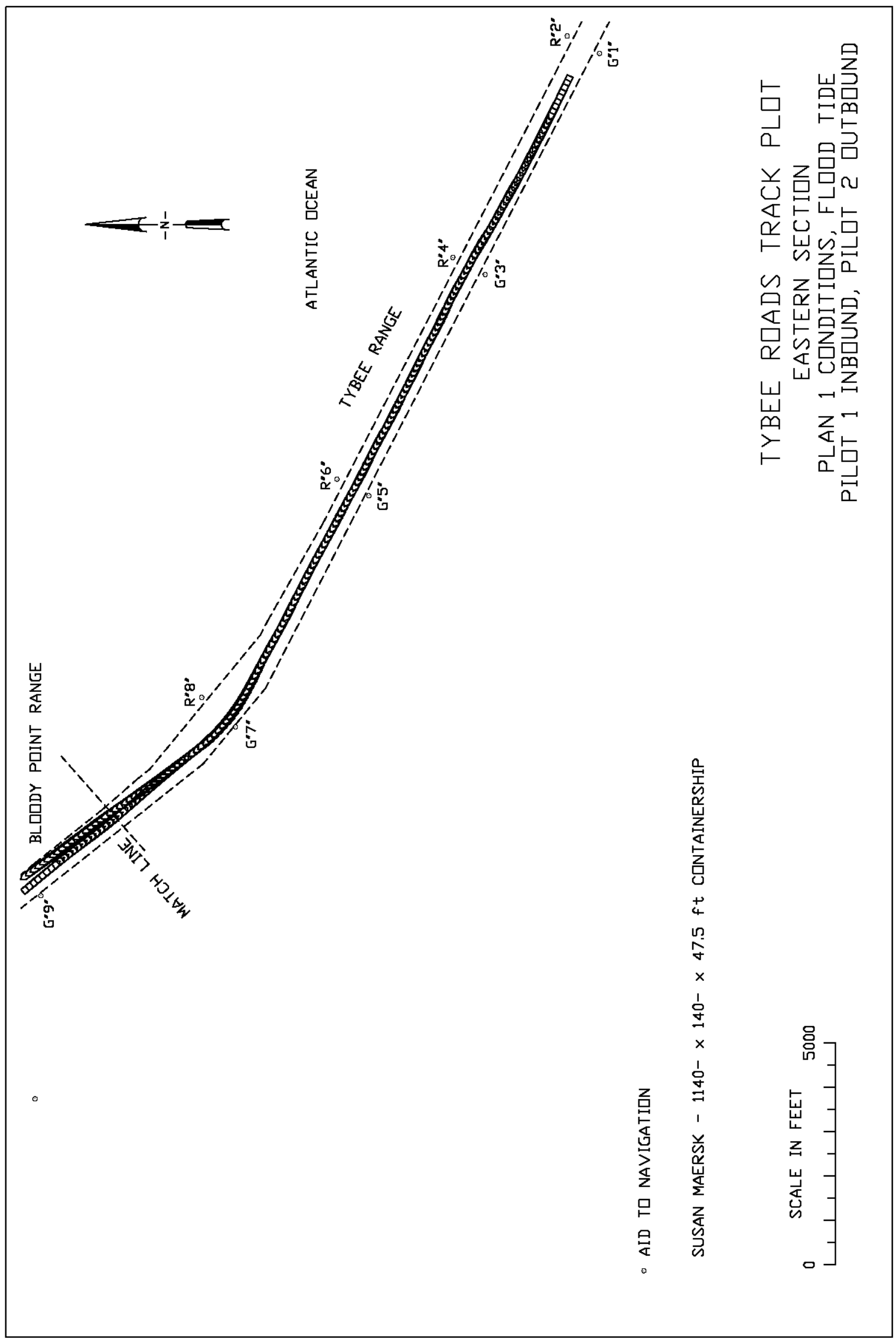

PLATE ट2 


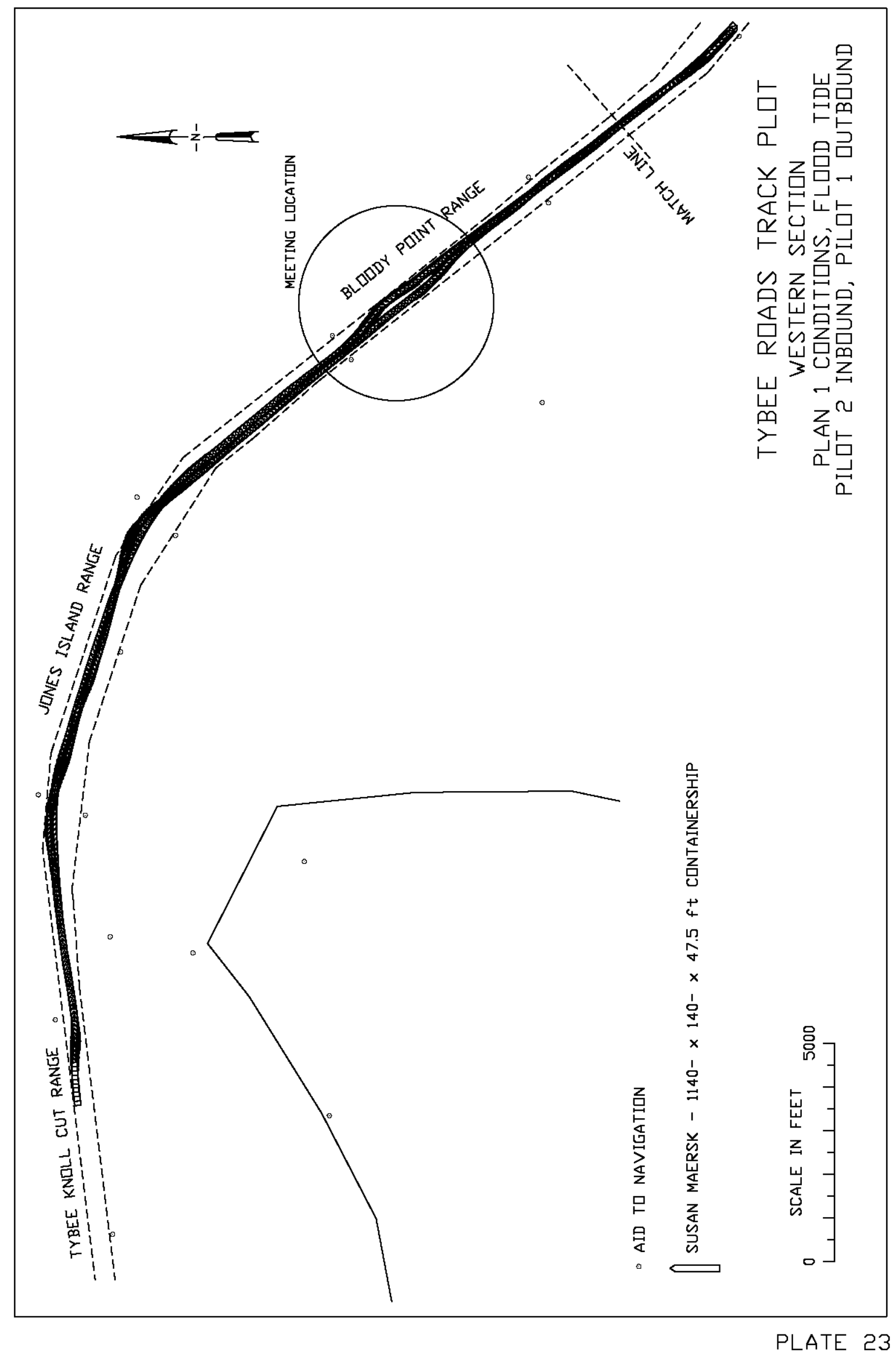




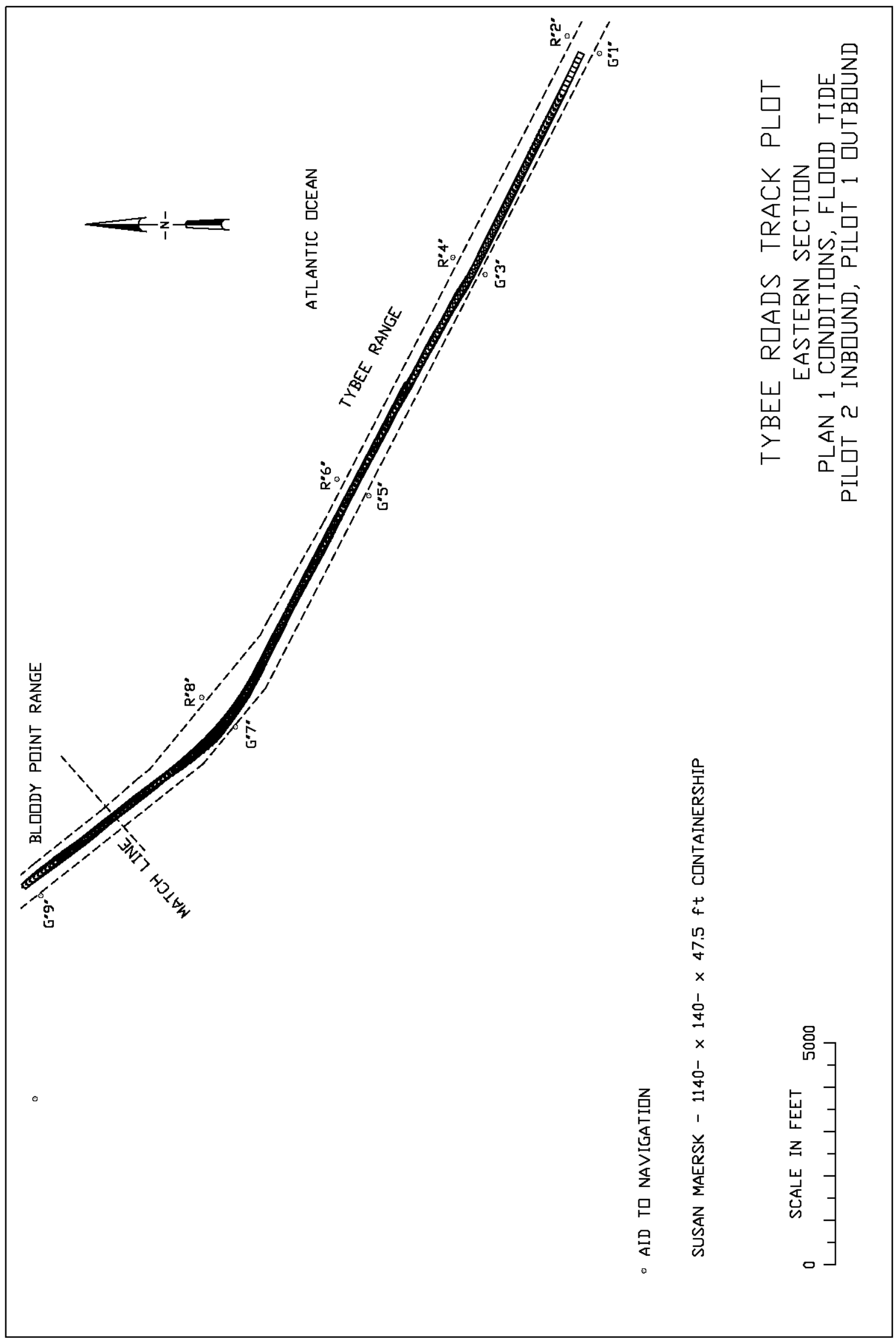

PLATE 24 


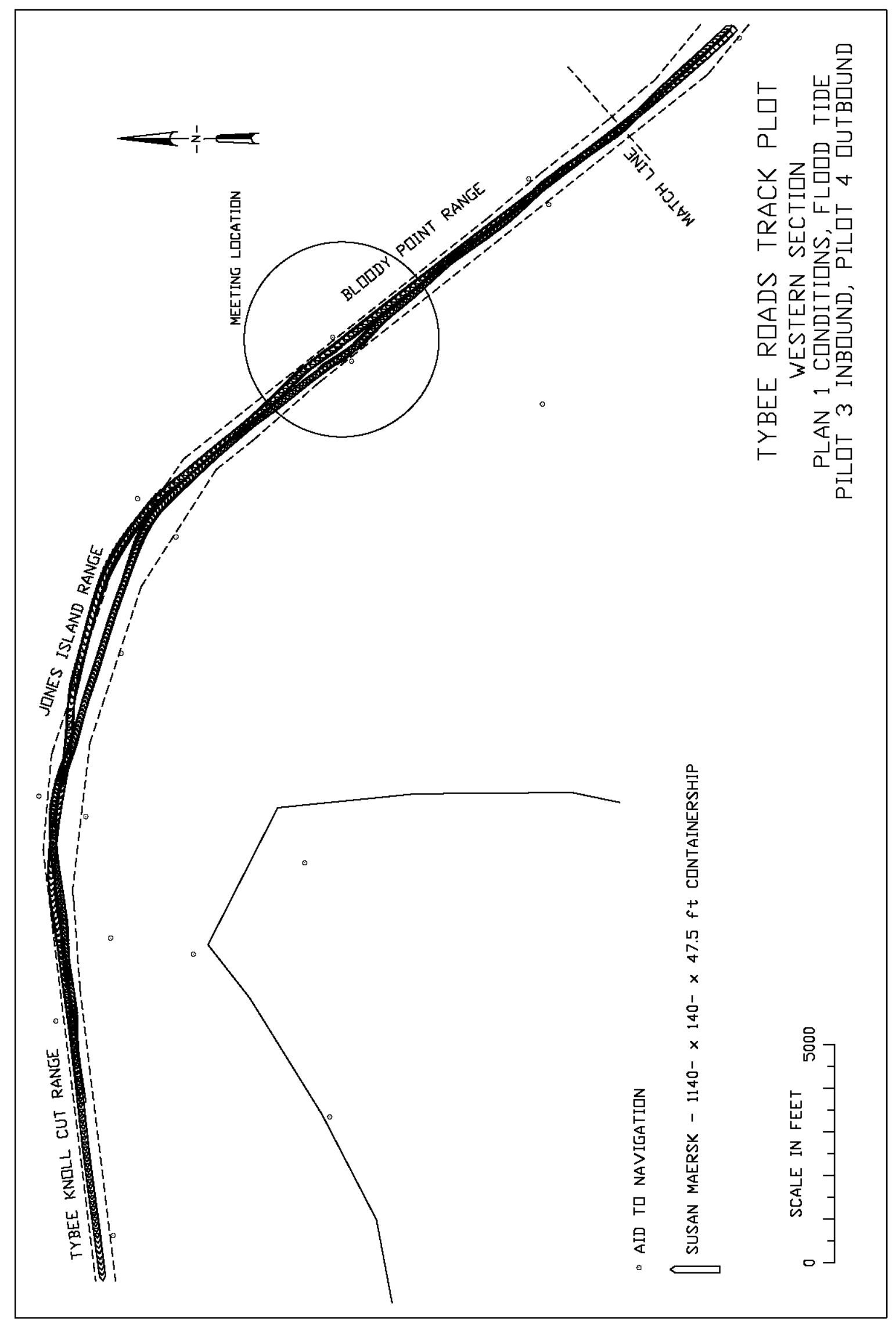

PLATE 25 


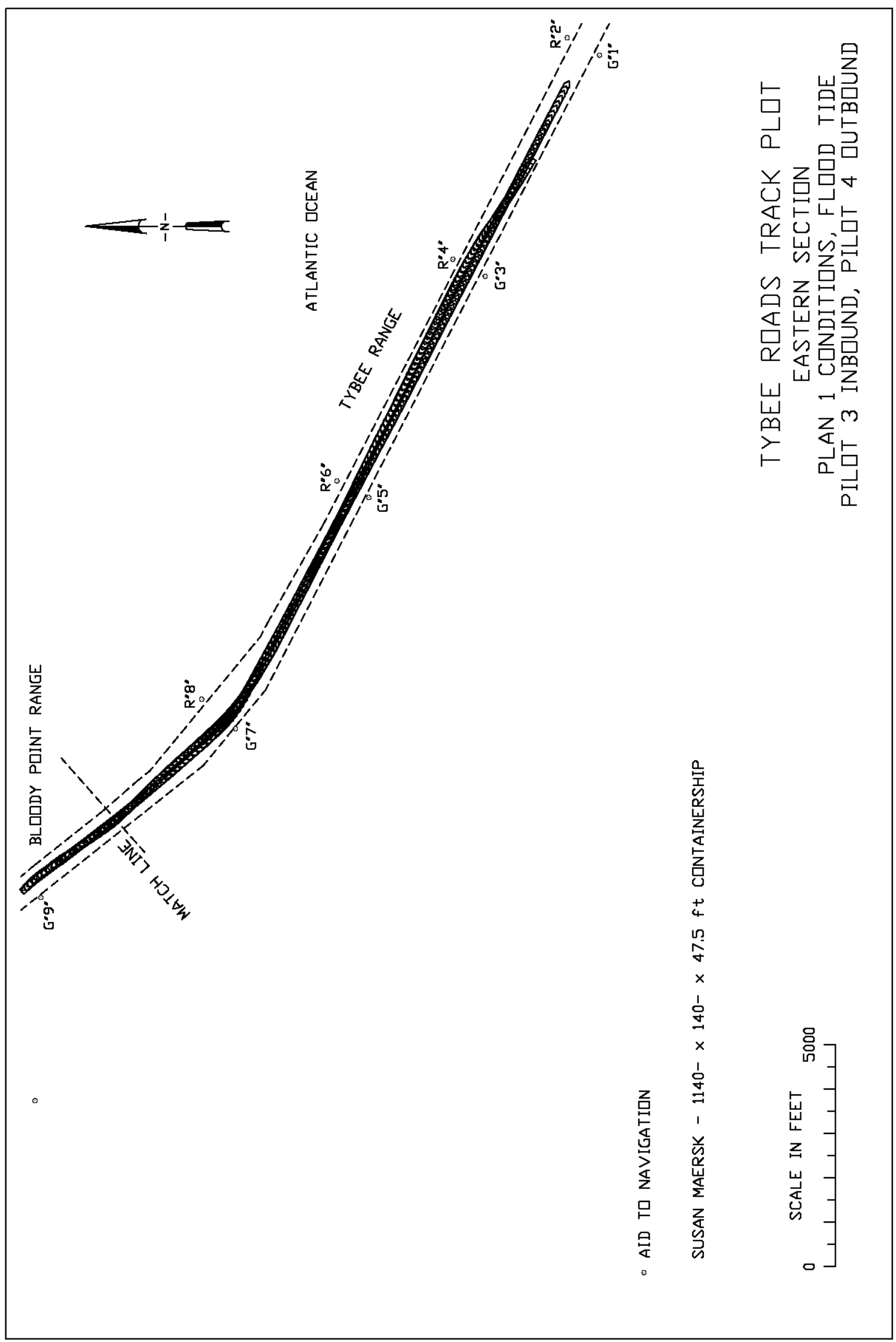

PLATE 26 


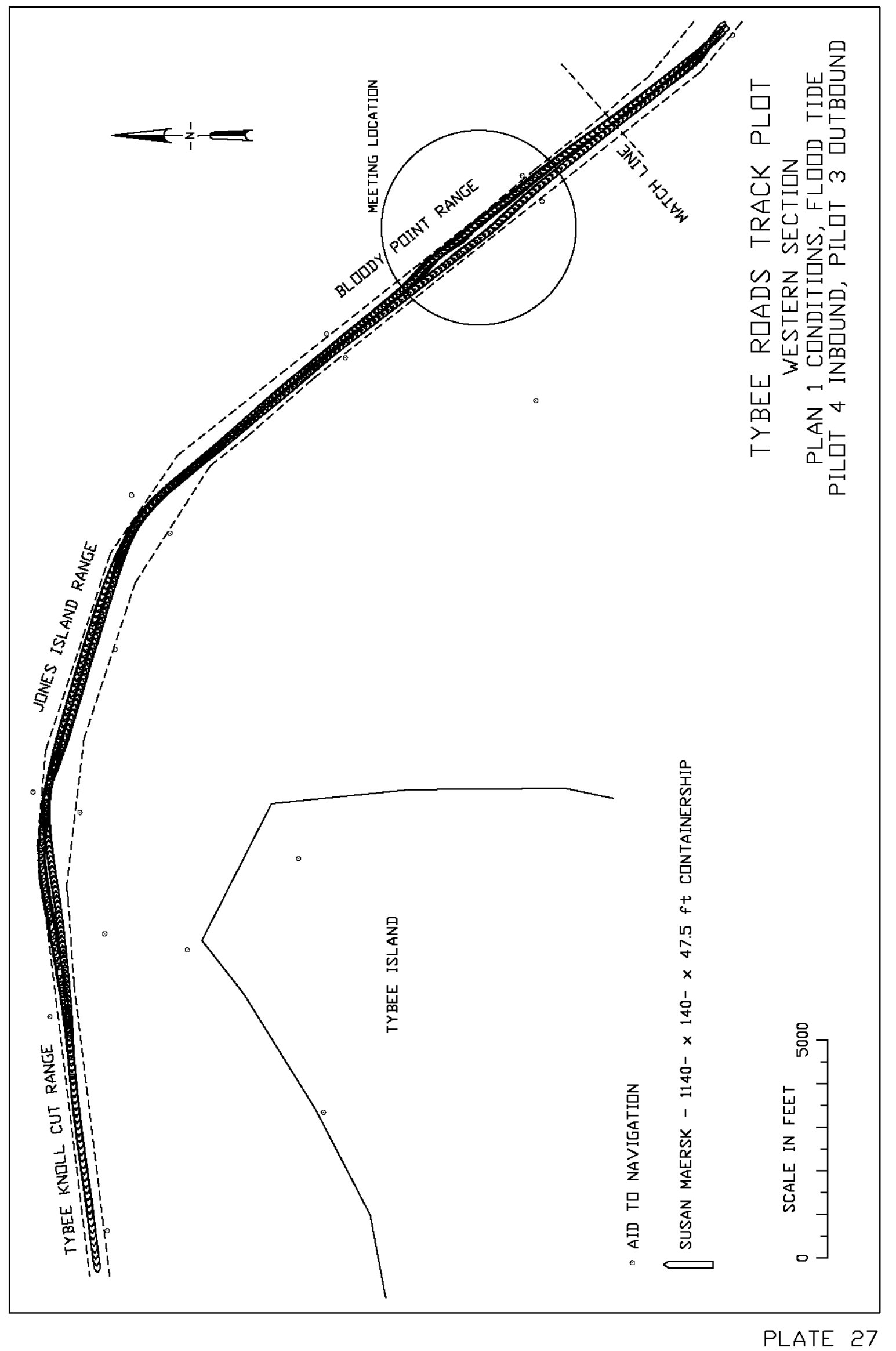




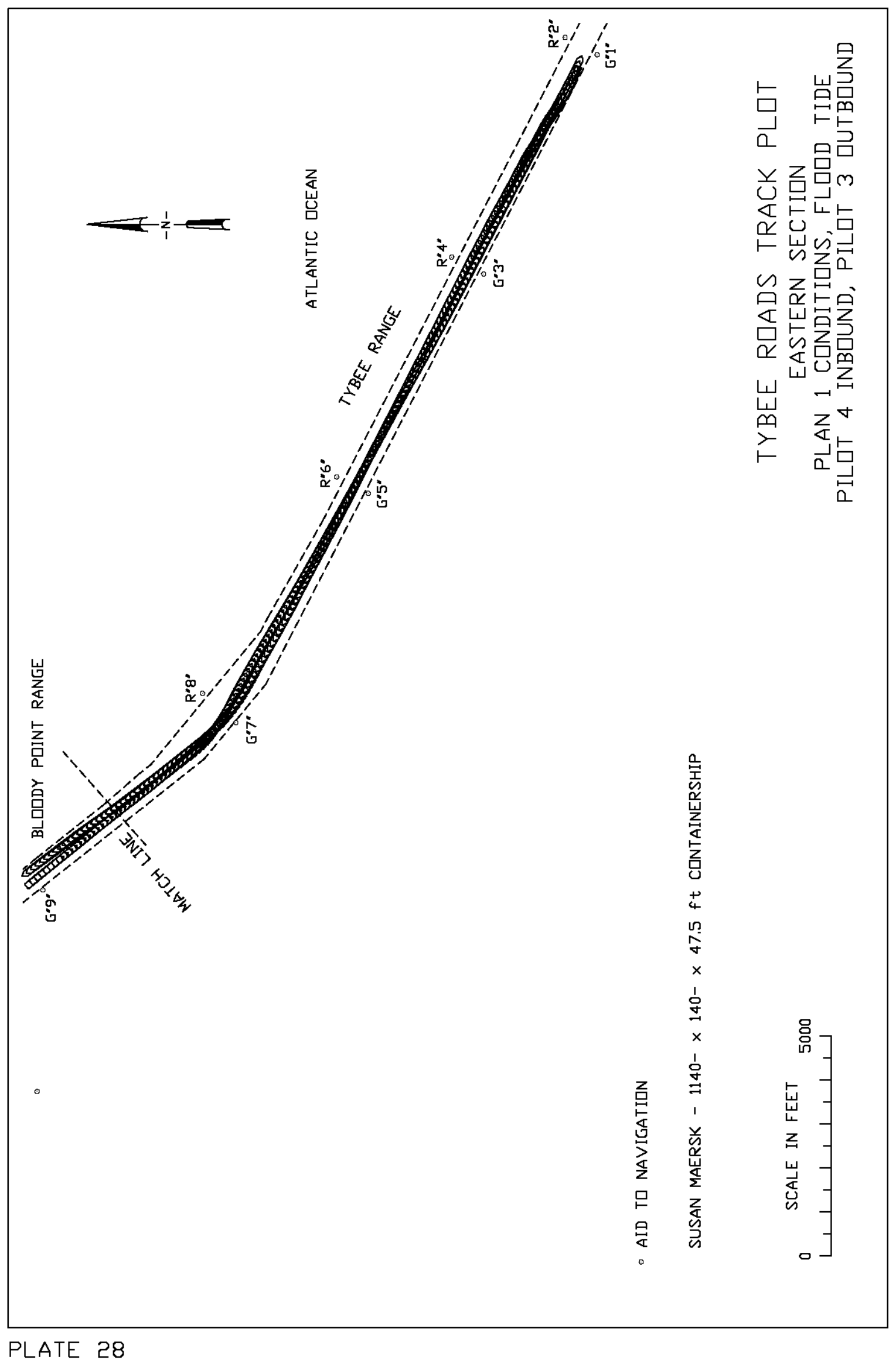




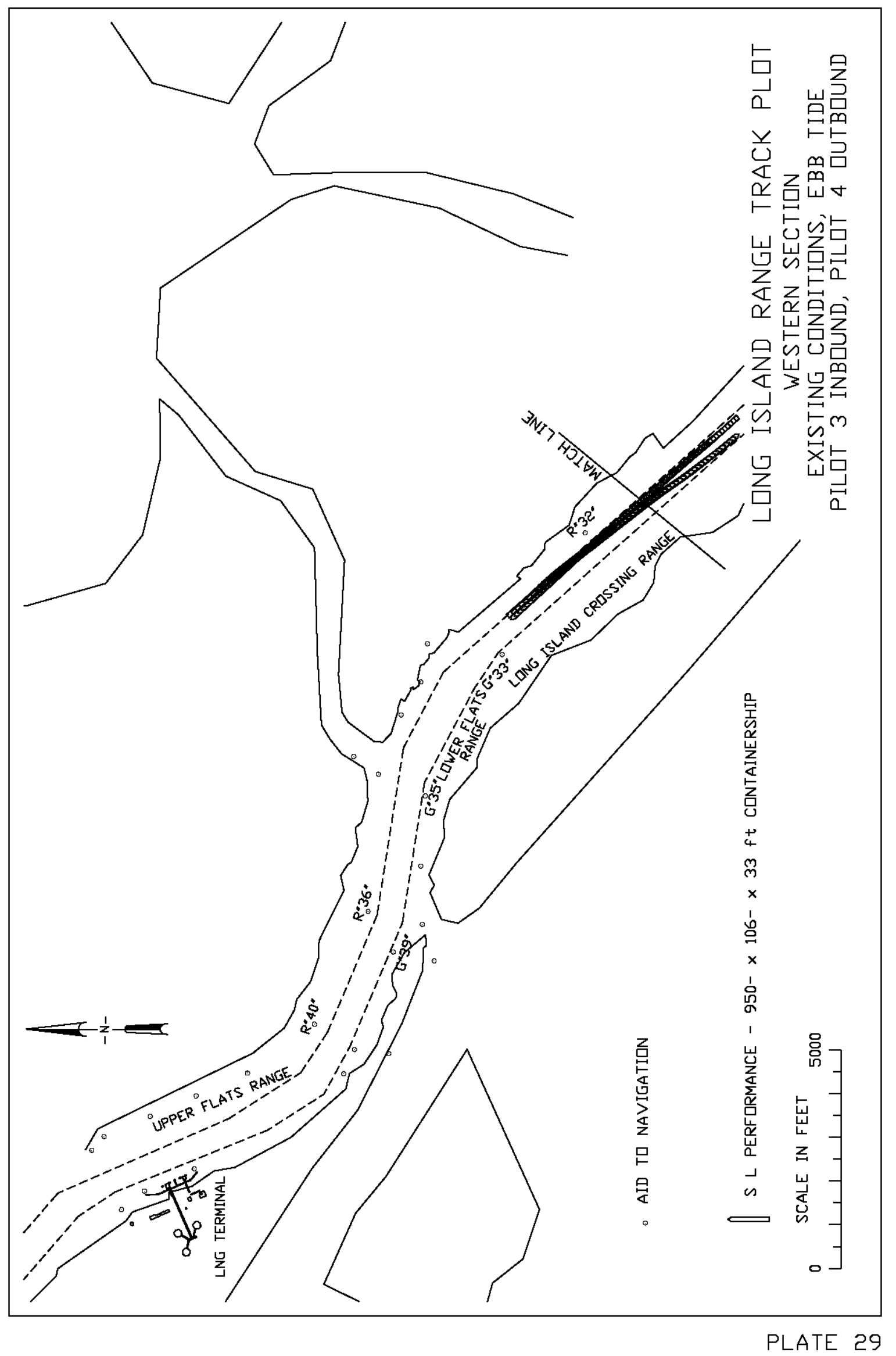




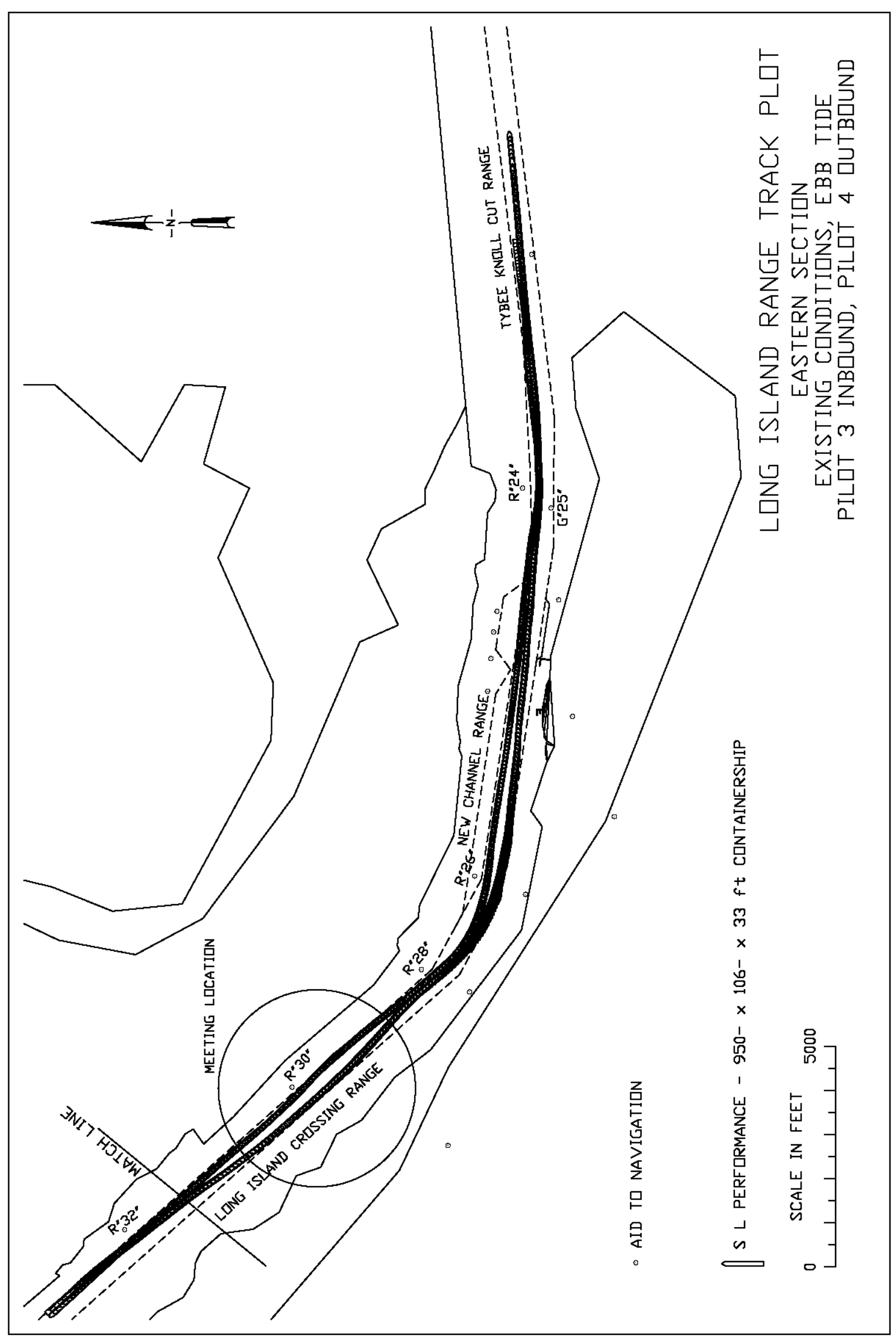

PLATE 30 


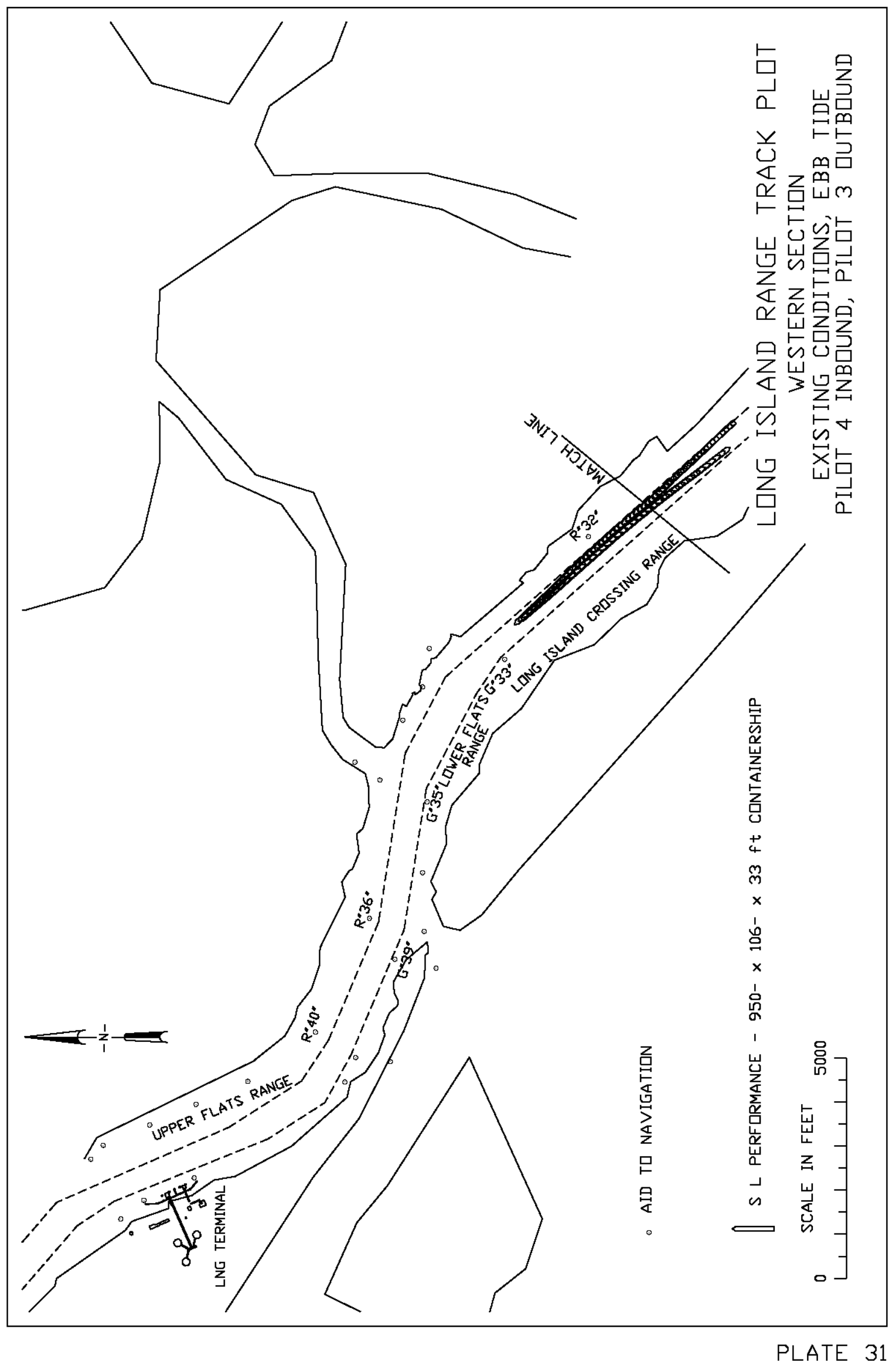




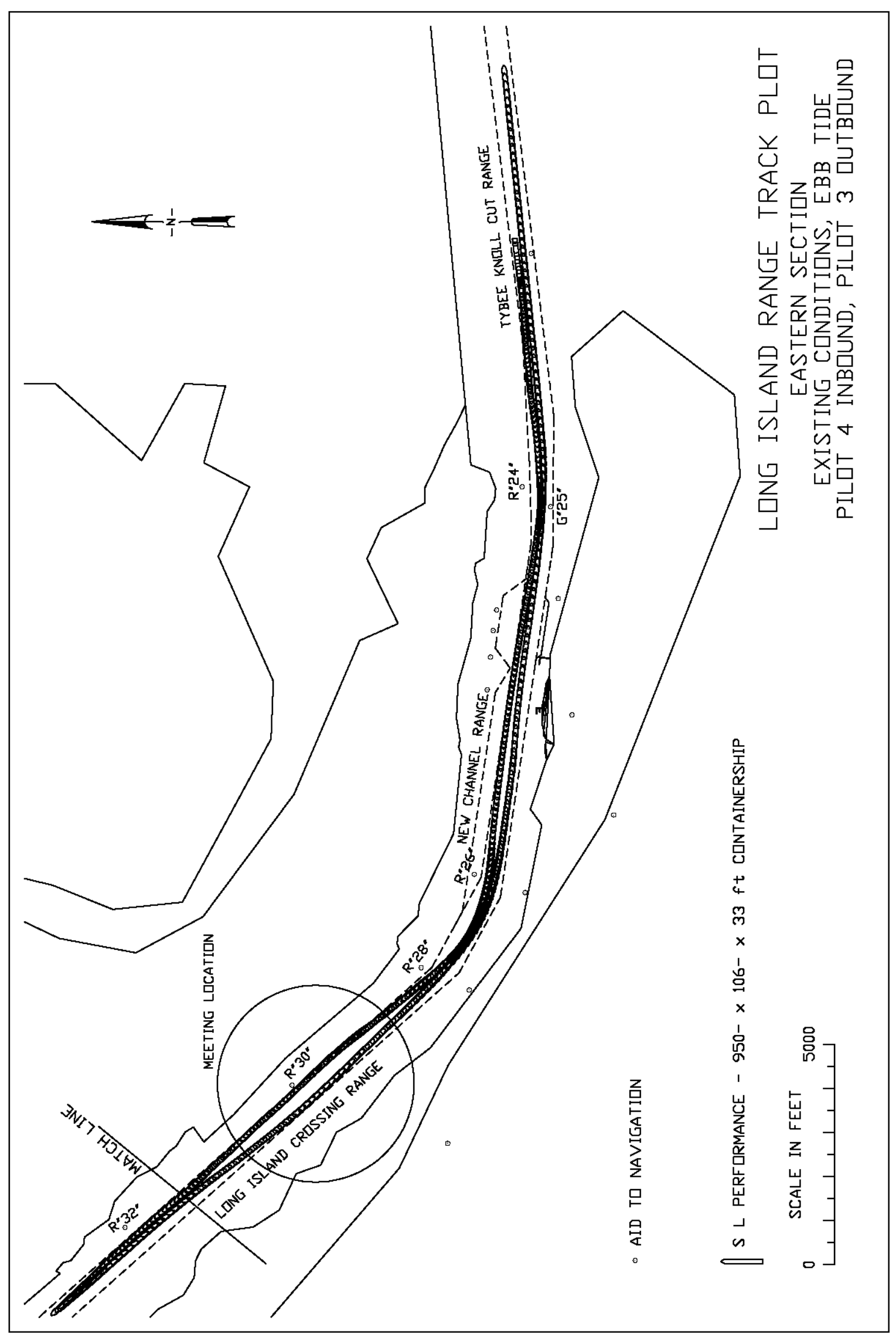

PLATE 32 


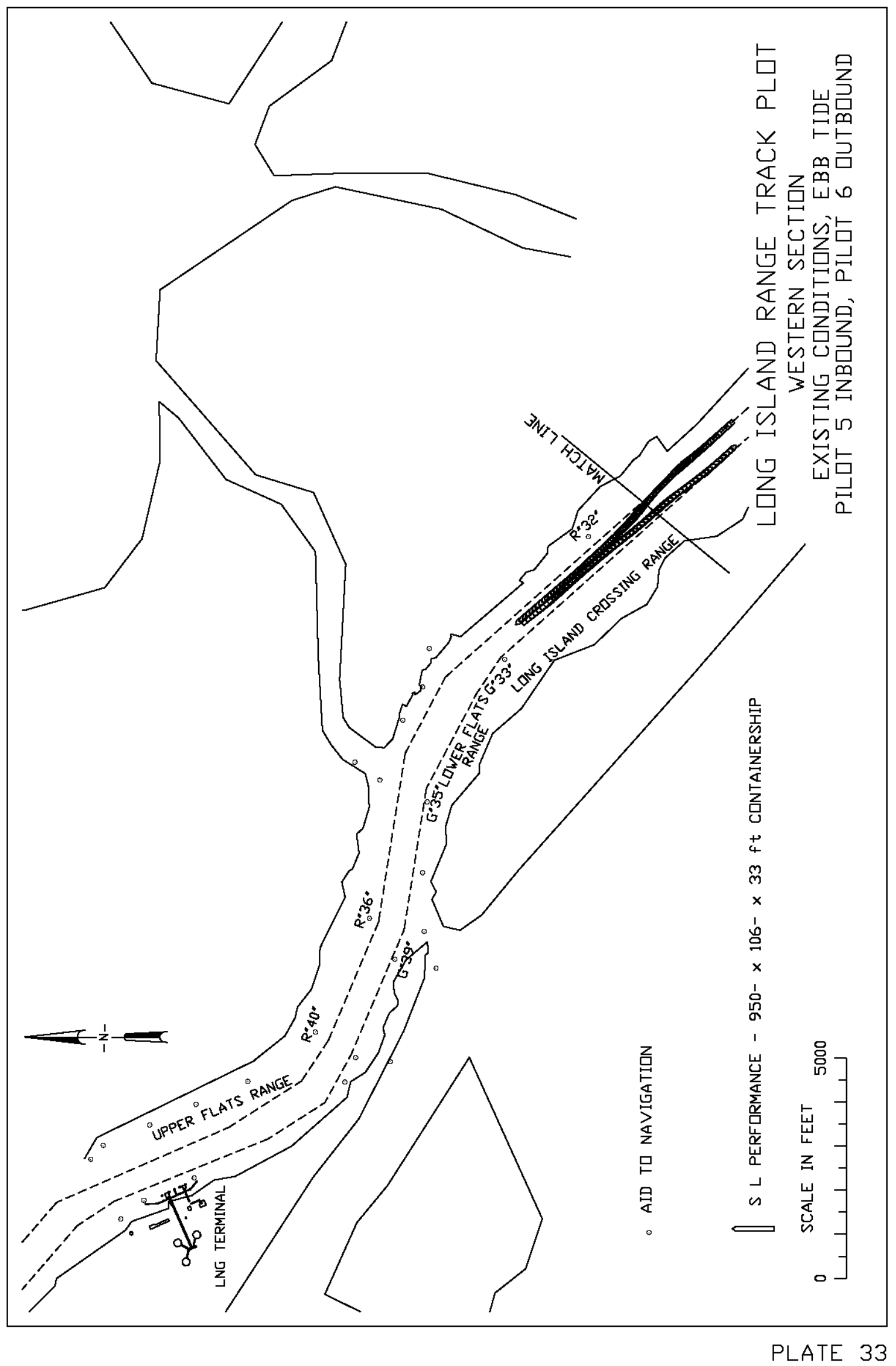




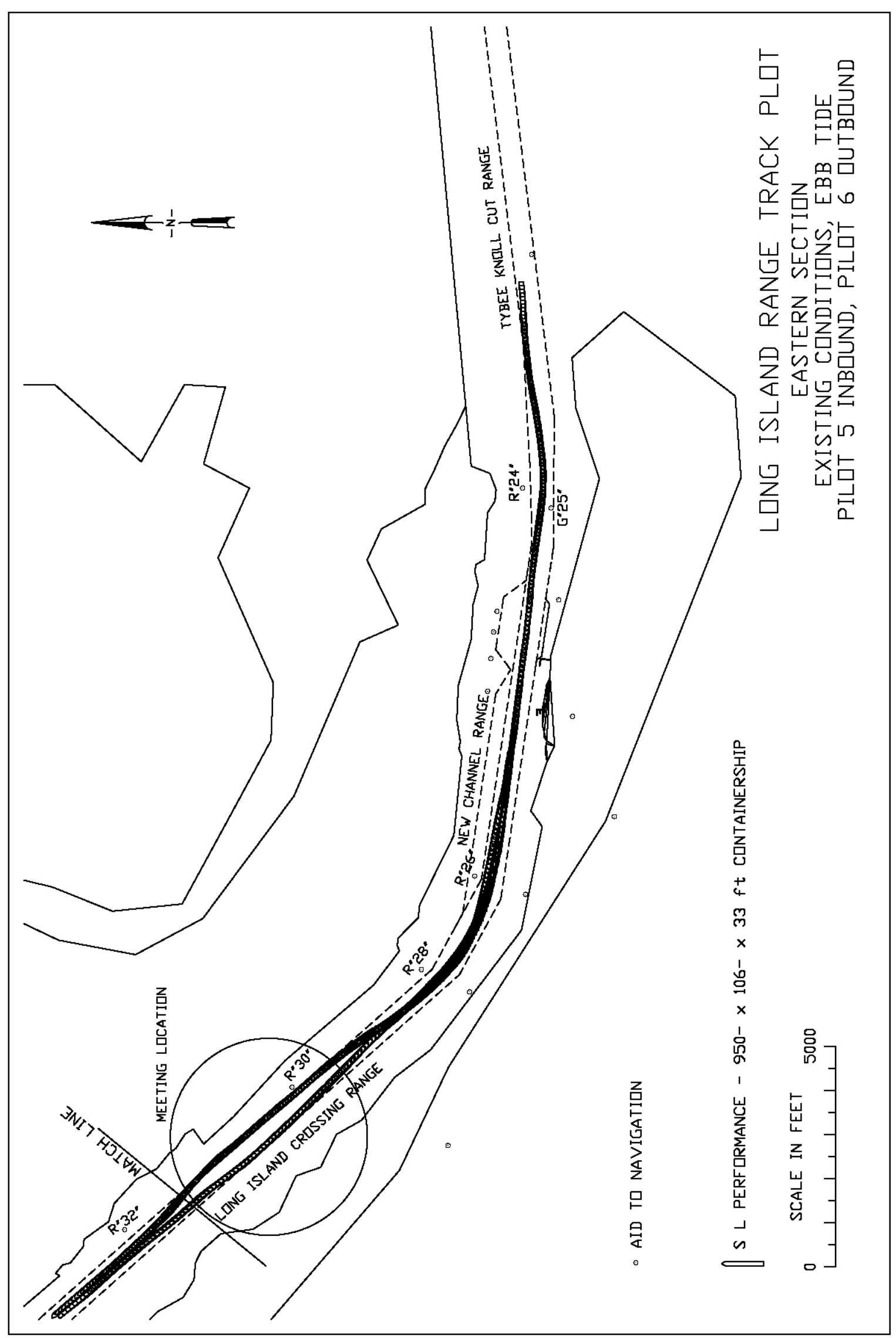

PLATE 34 


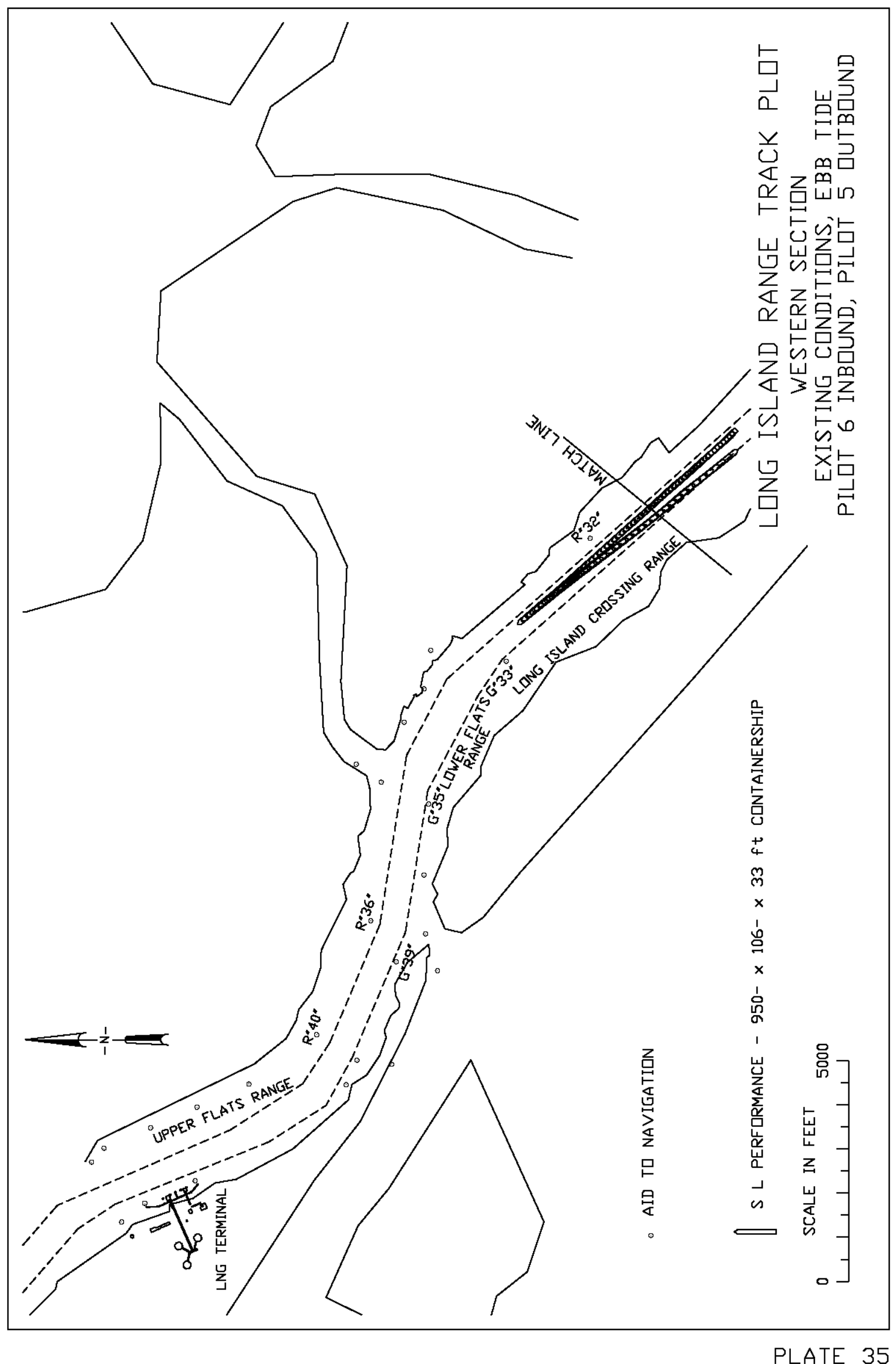




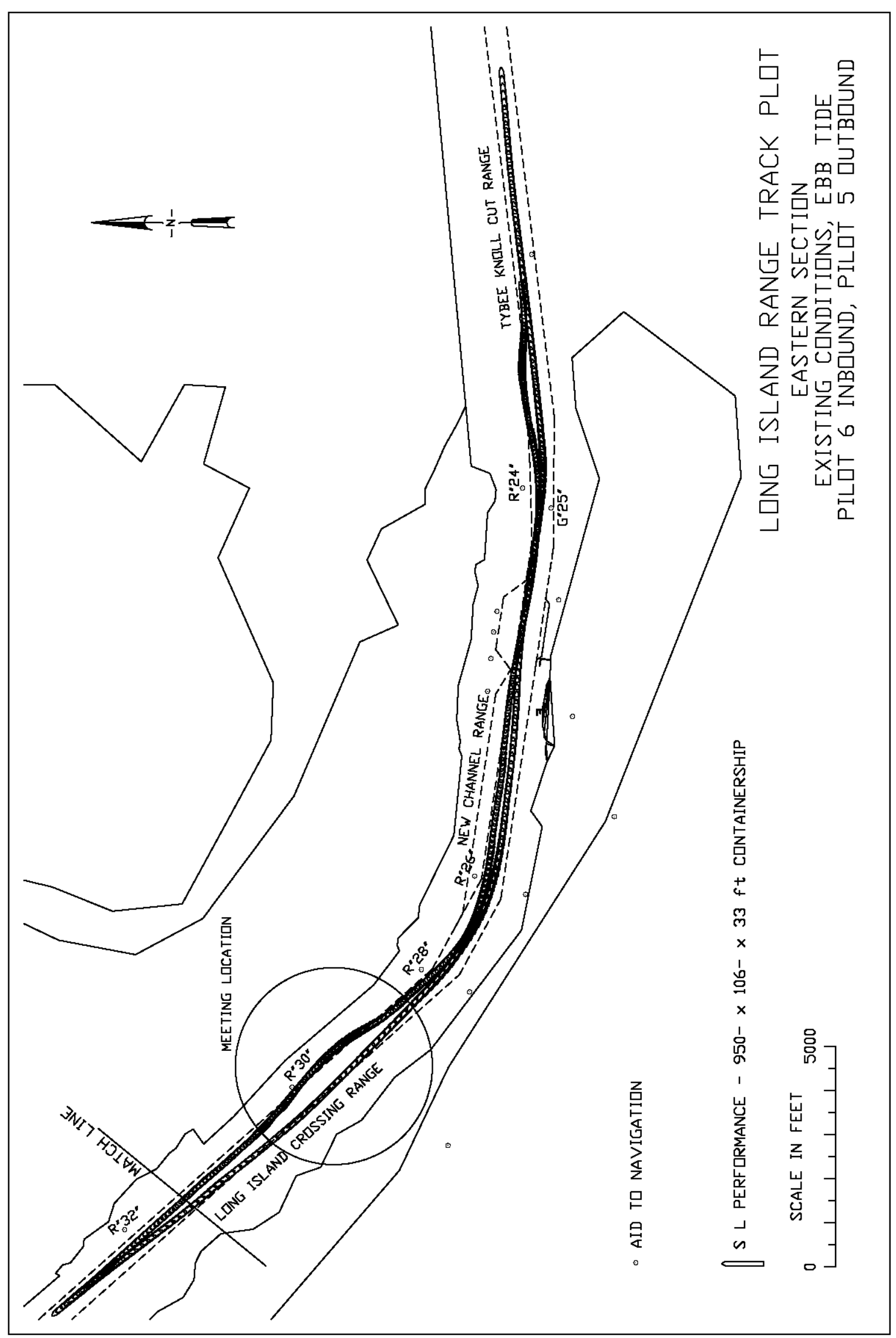

PLATE 36 


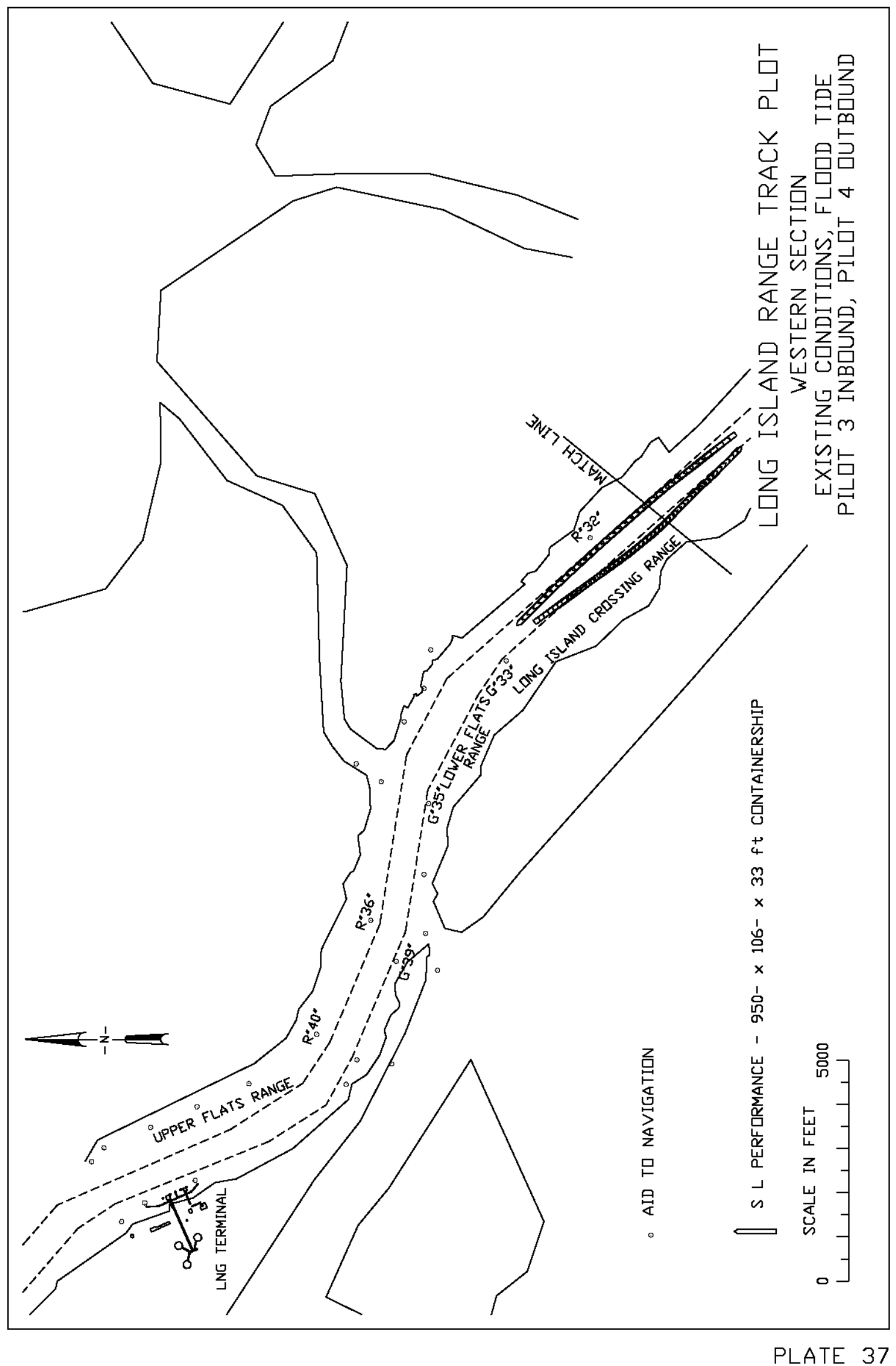




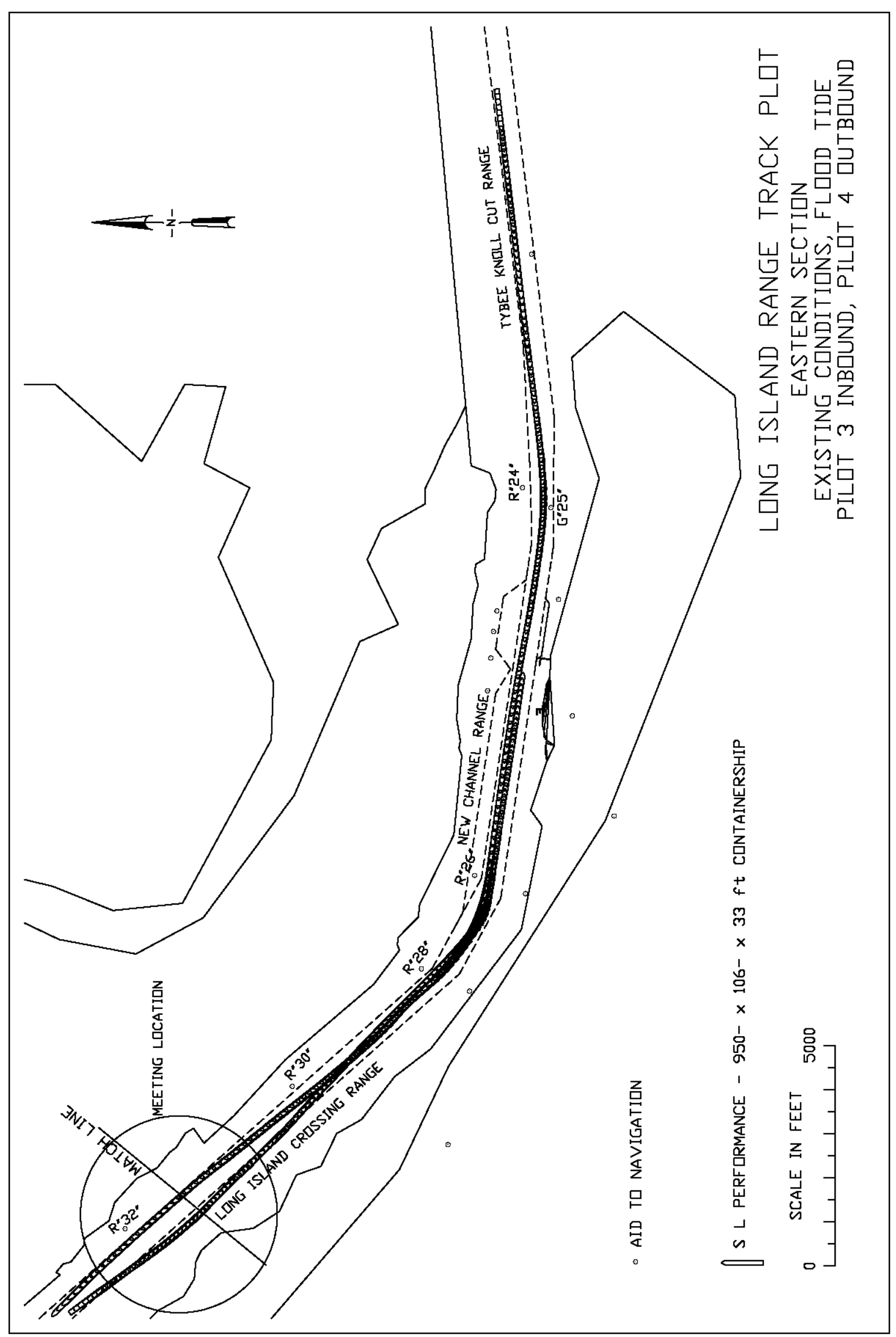

PLATE 38 


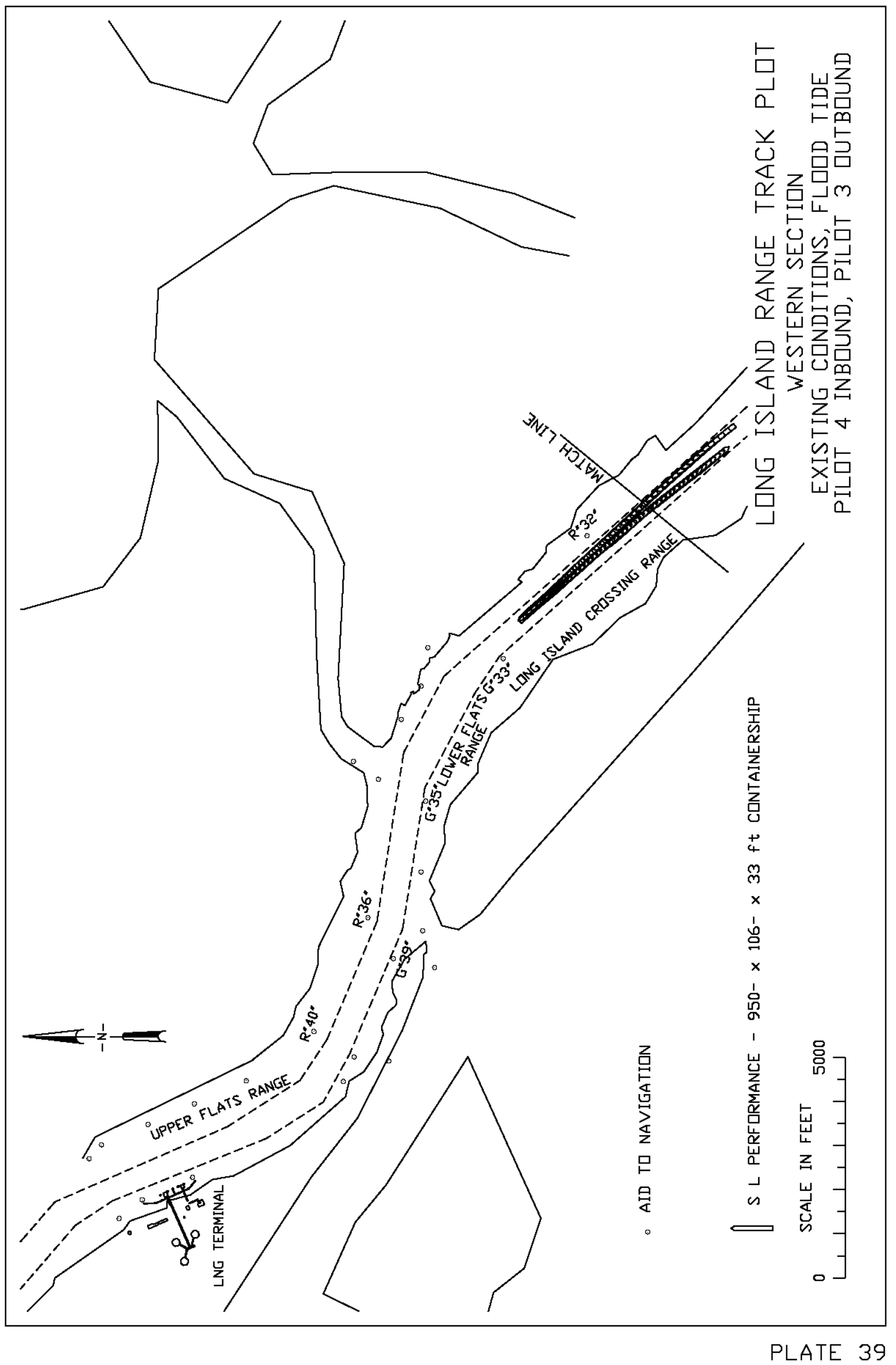




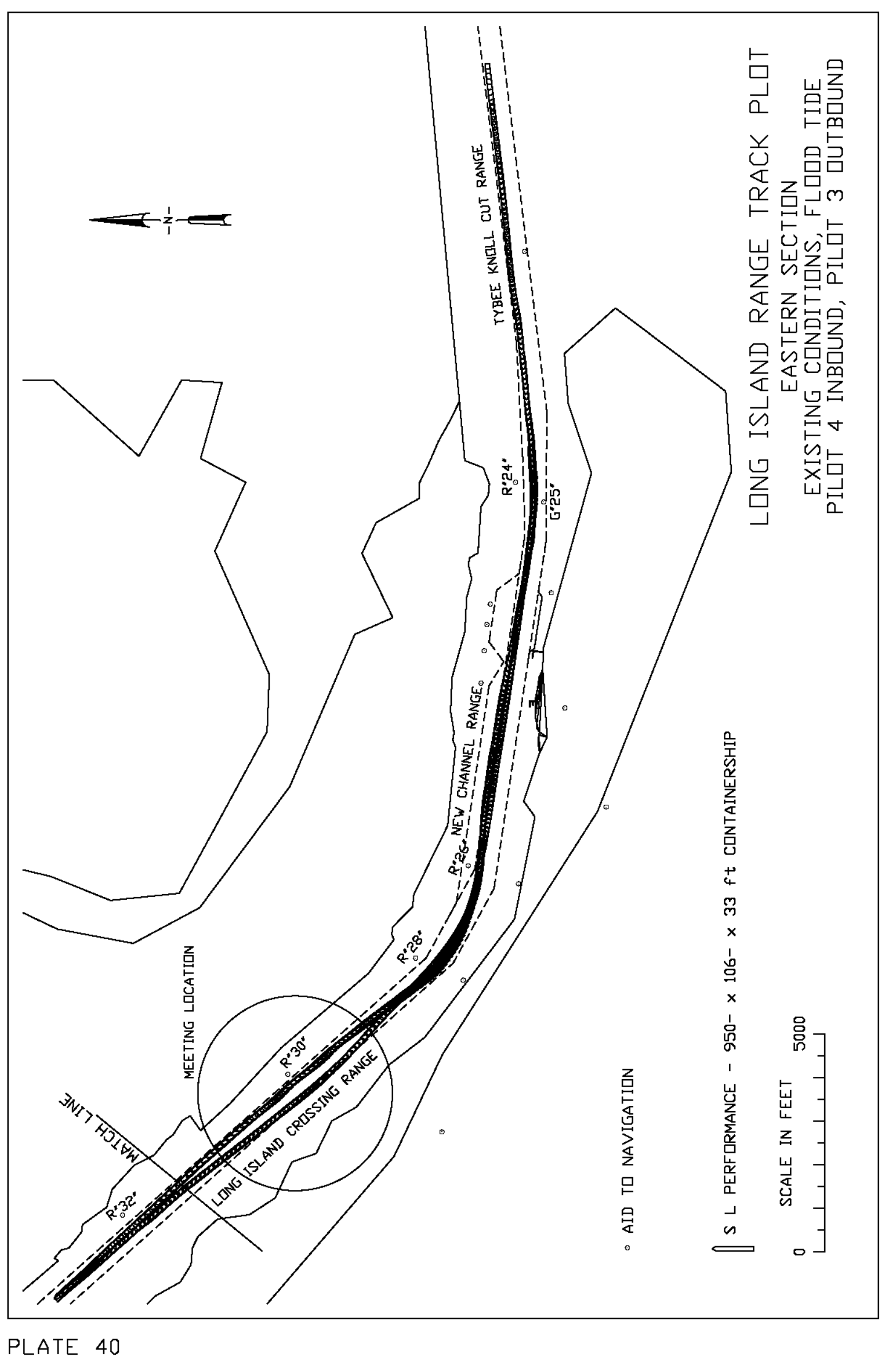




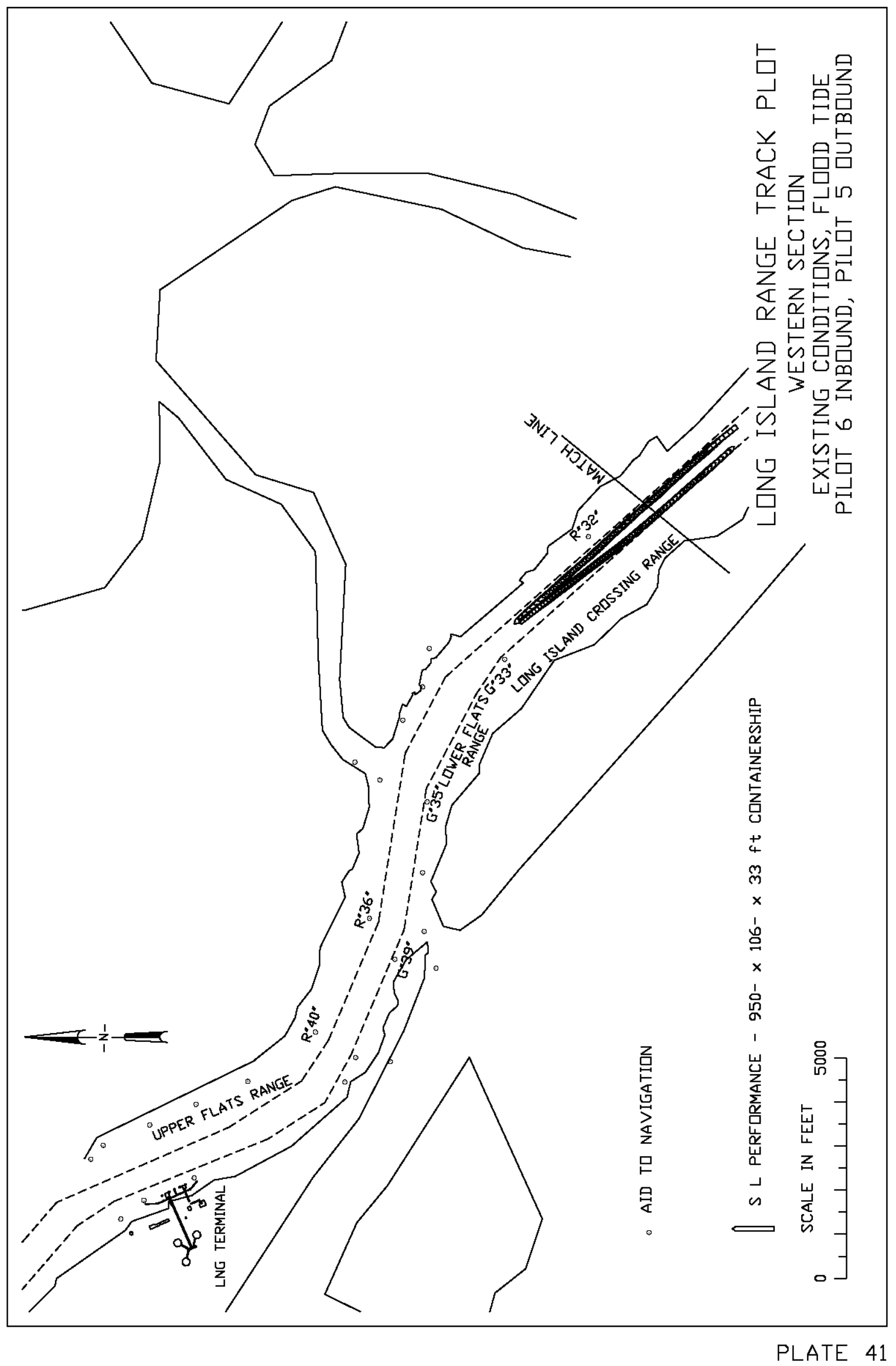




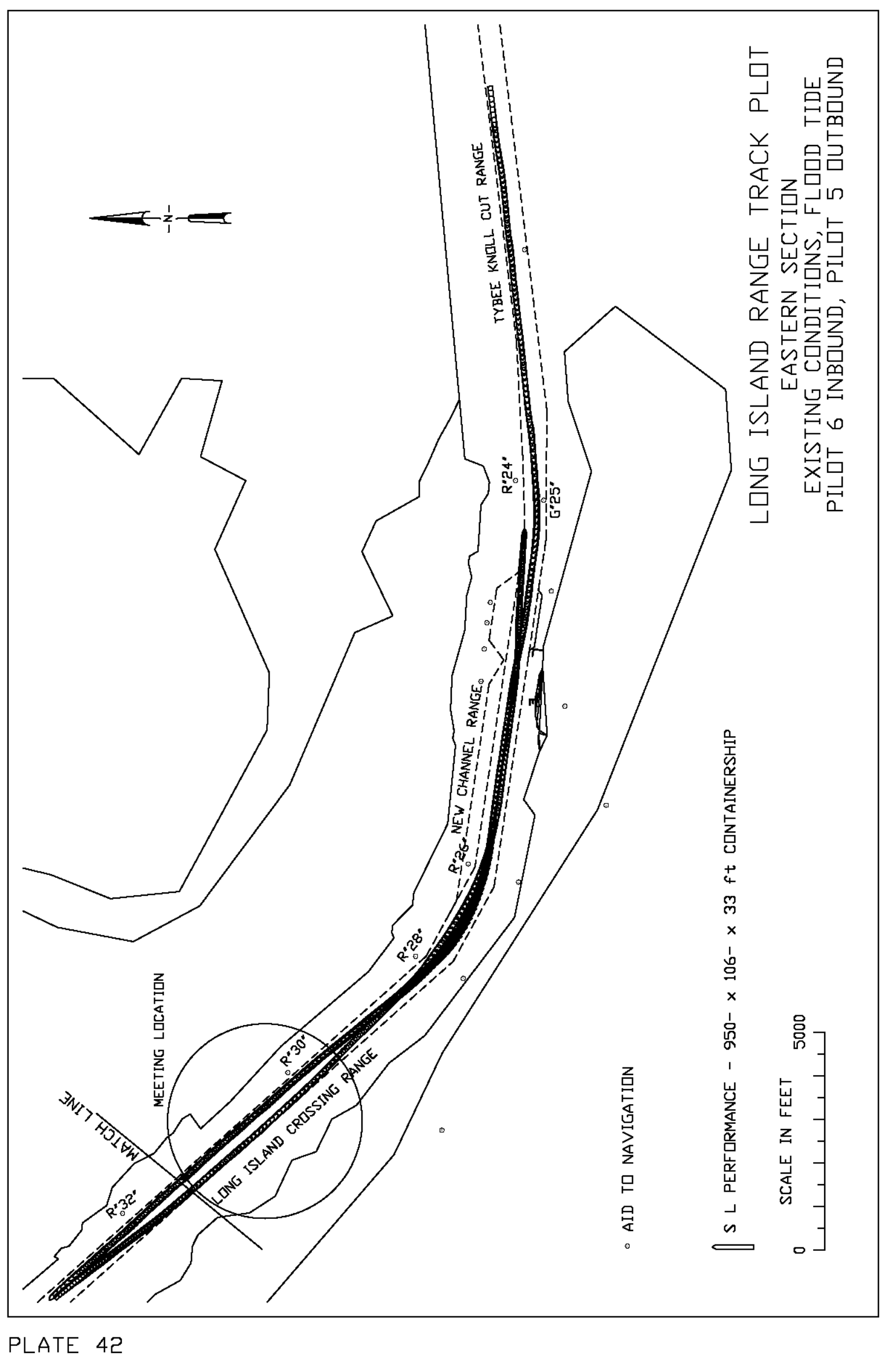




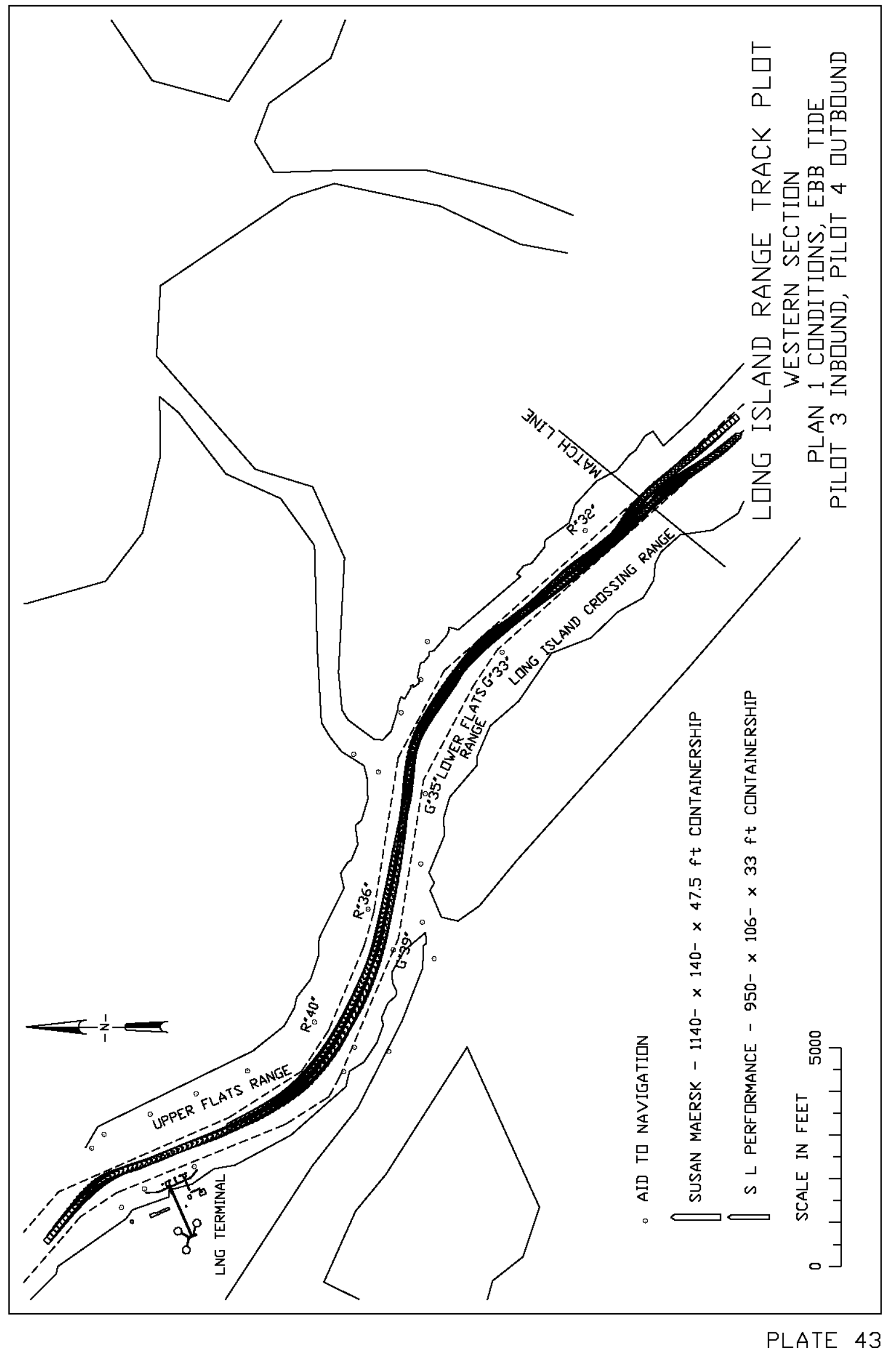




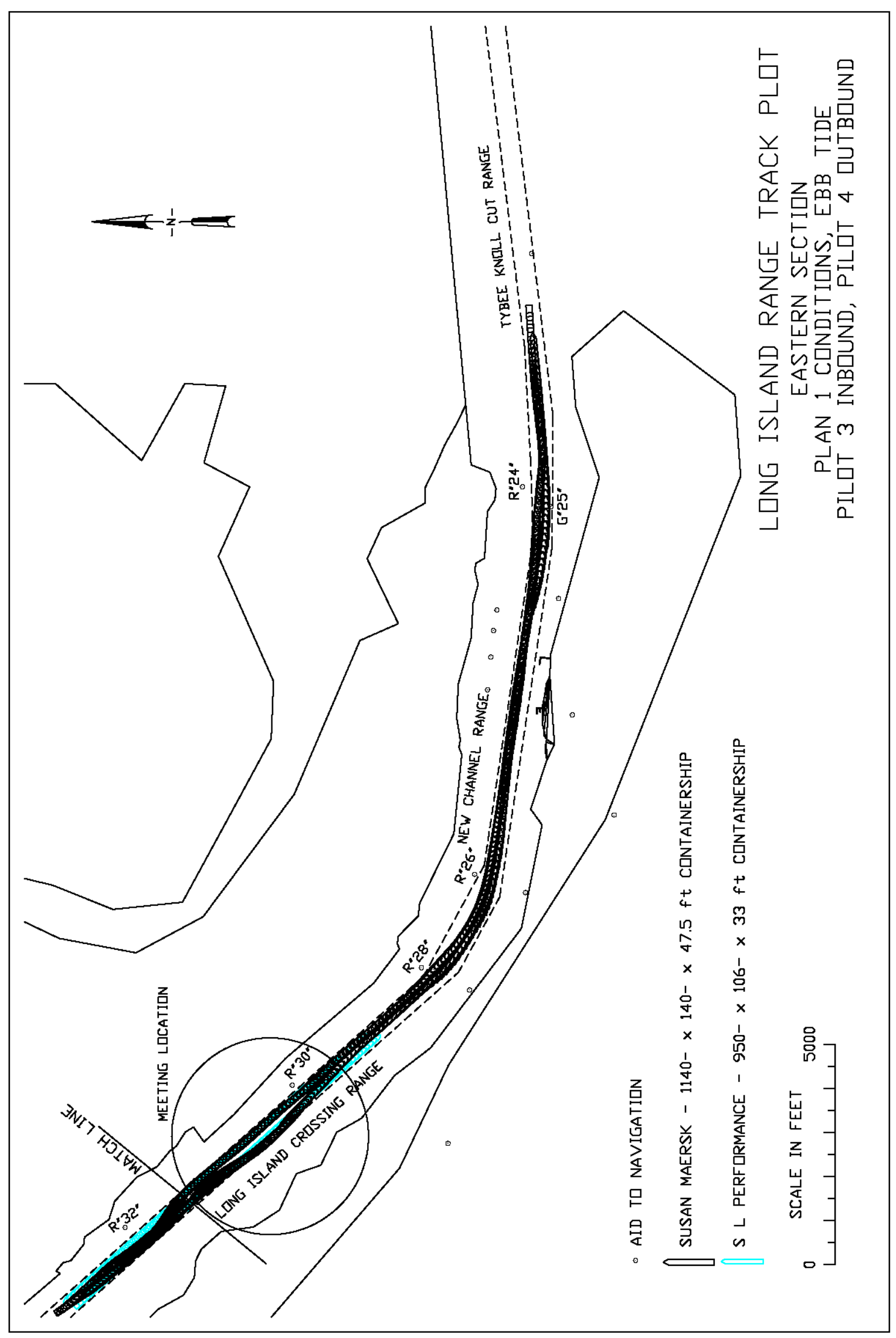

PLATE 44 


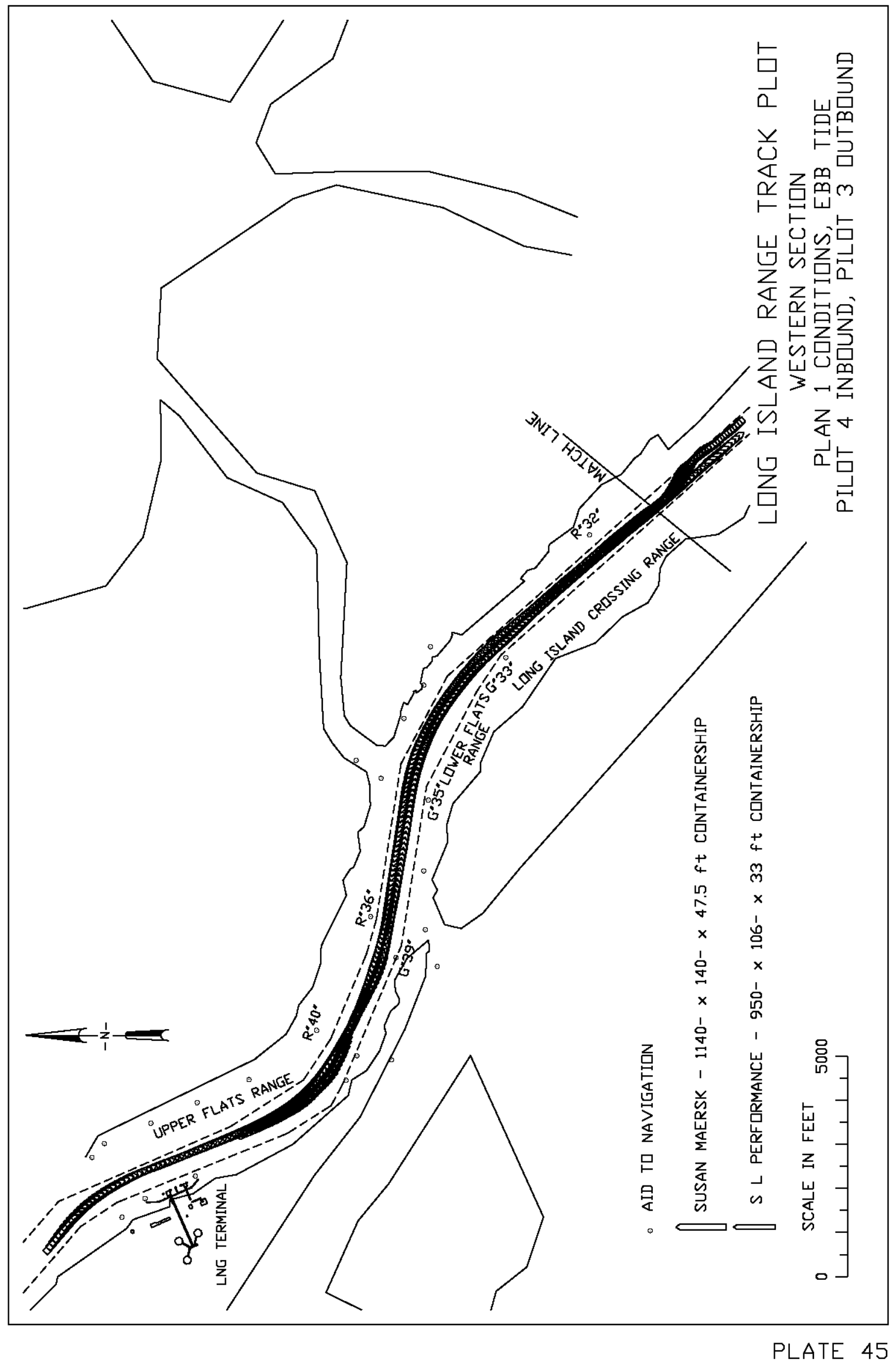




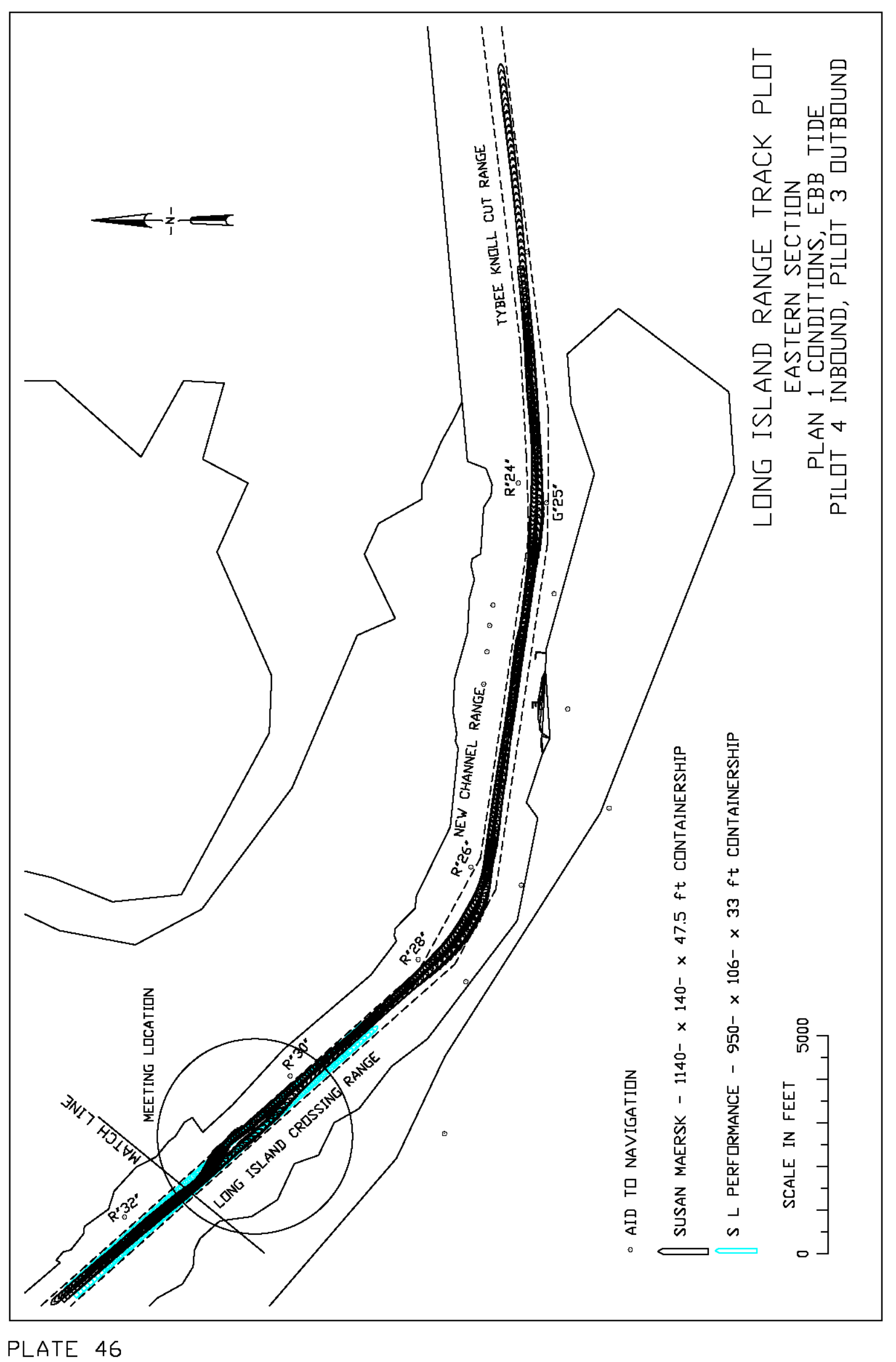




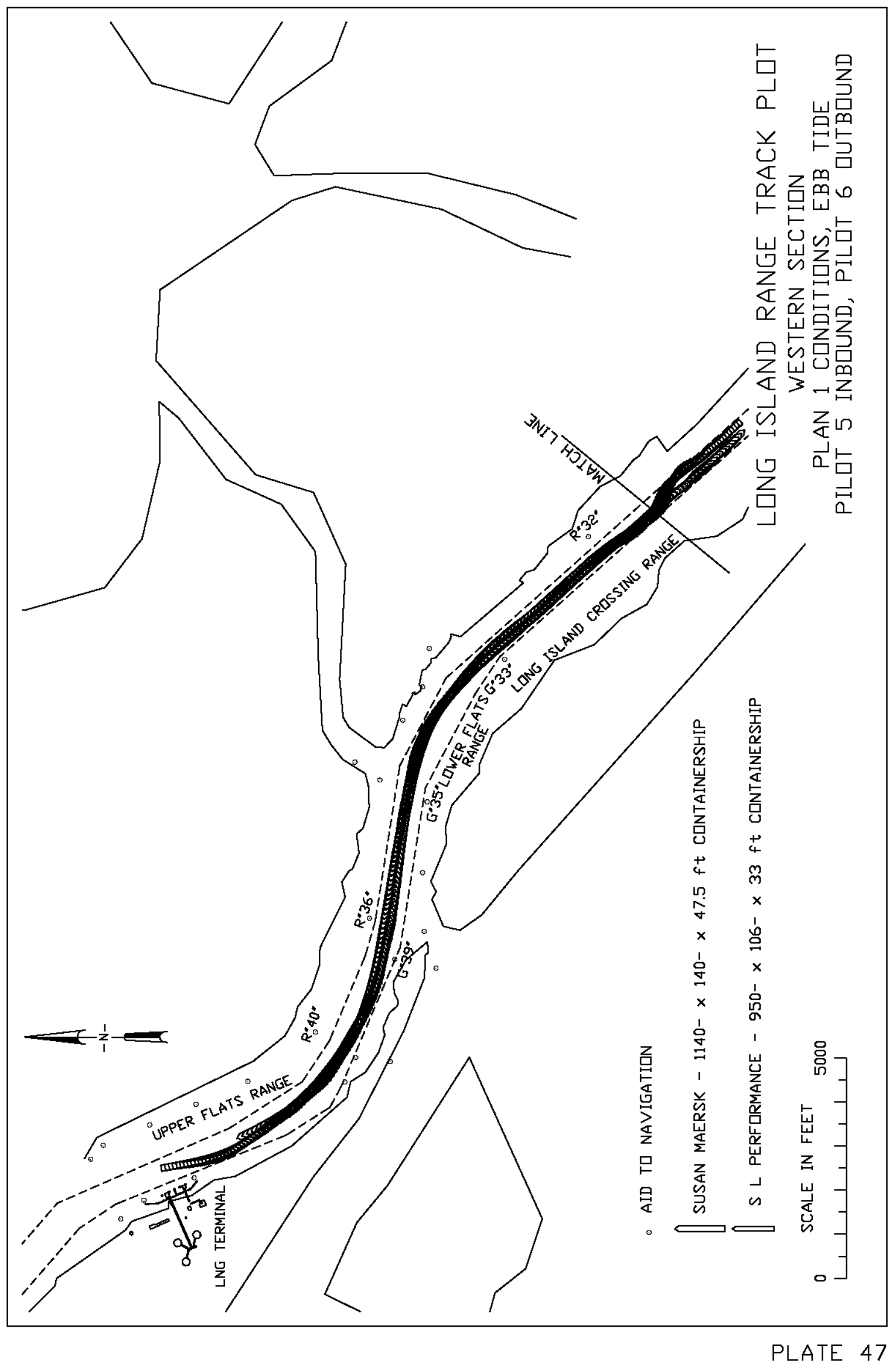




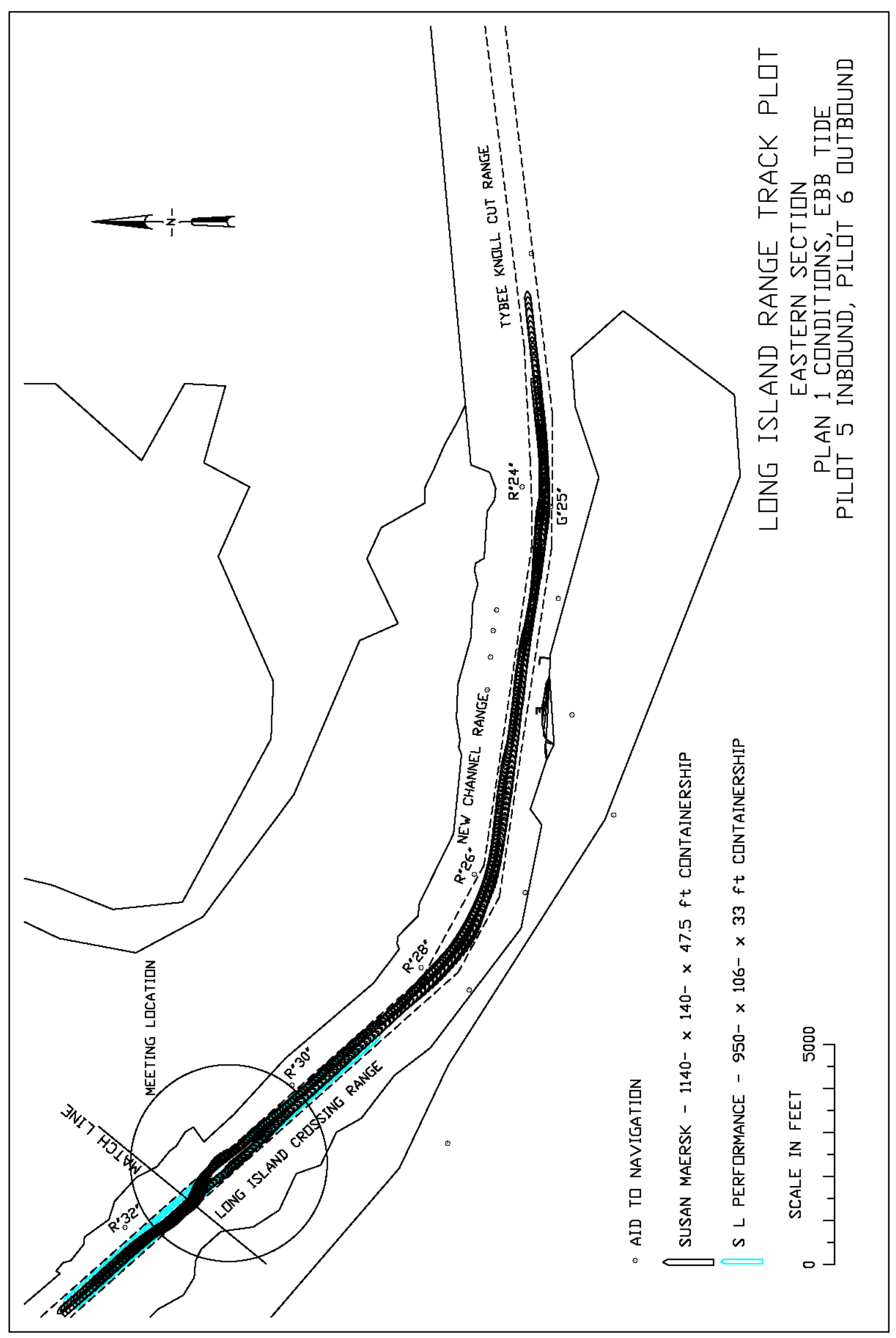

PLATE 48 


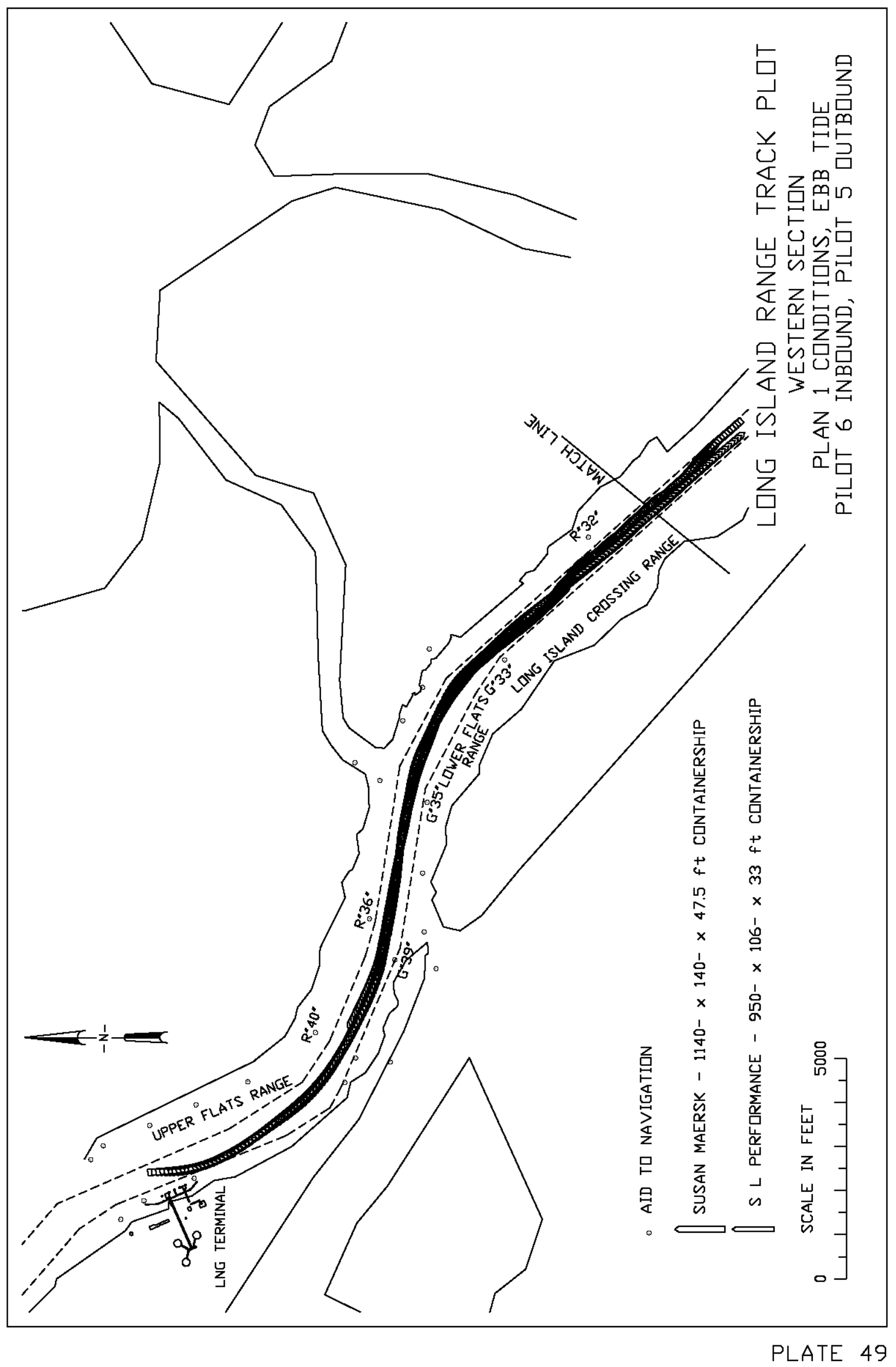




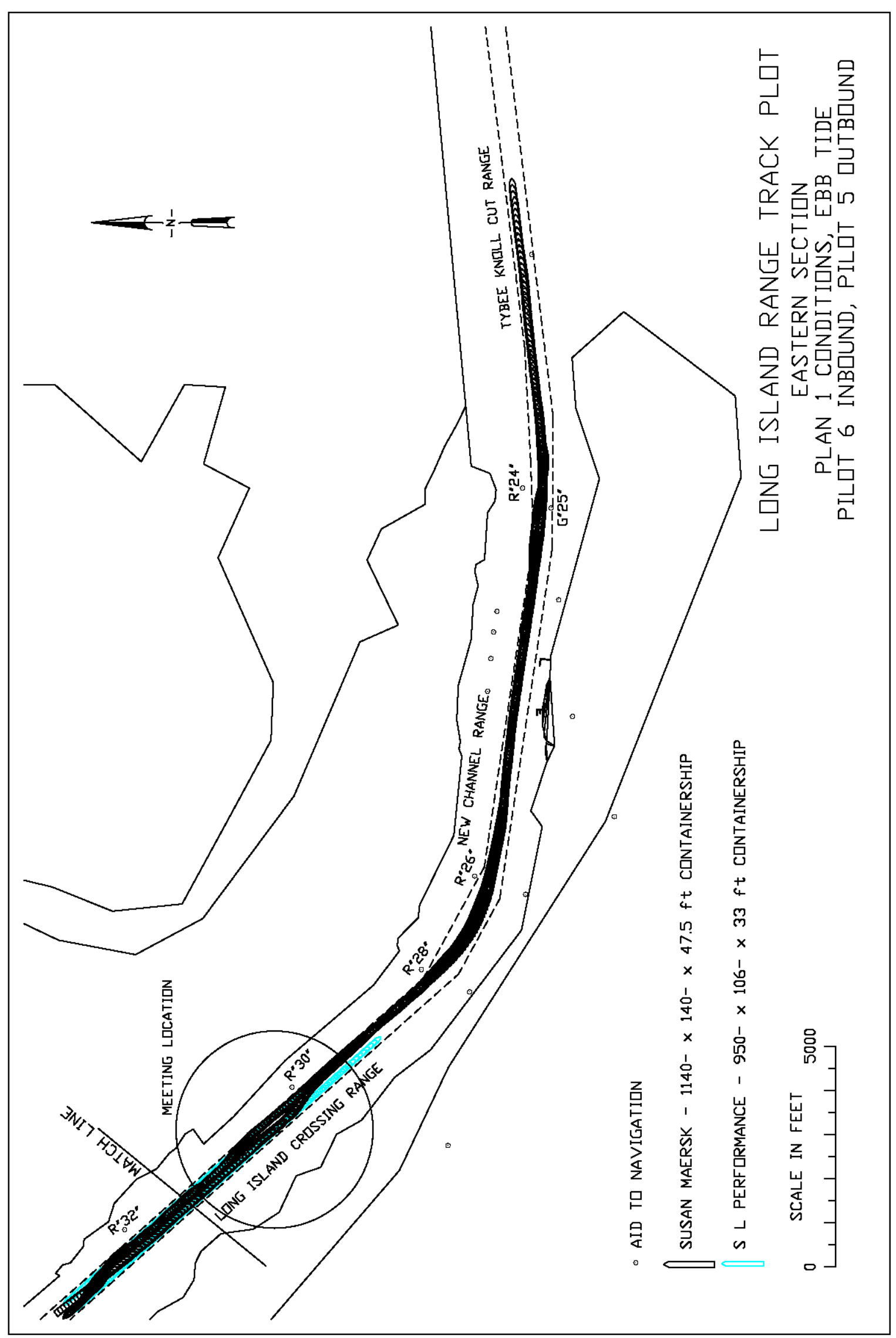

PLATE 50 


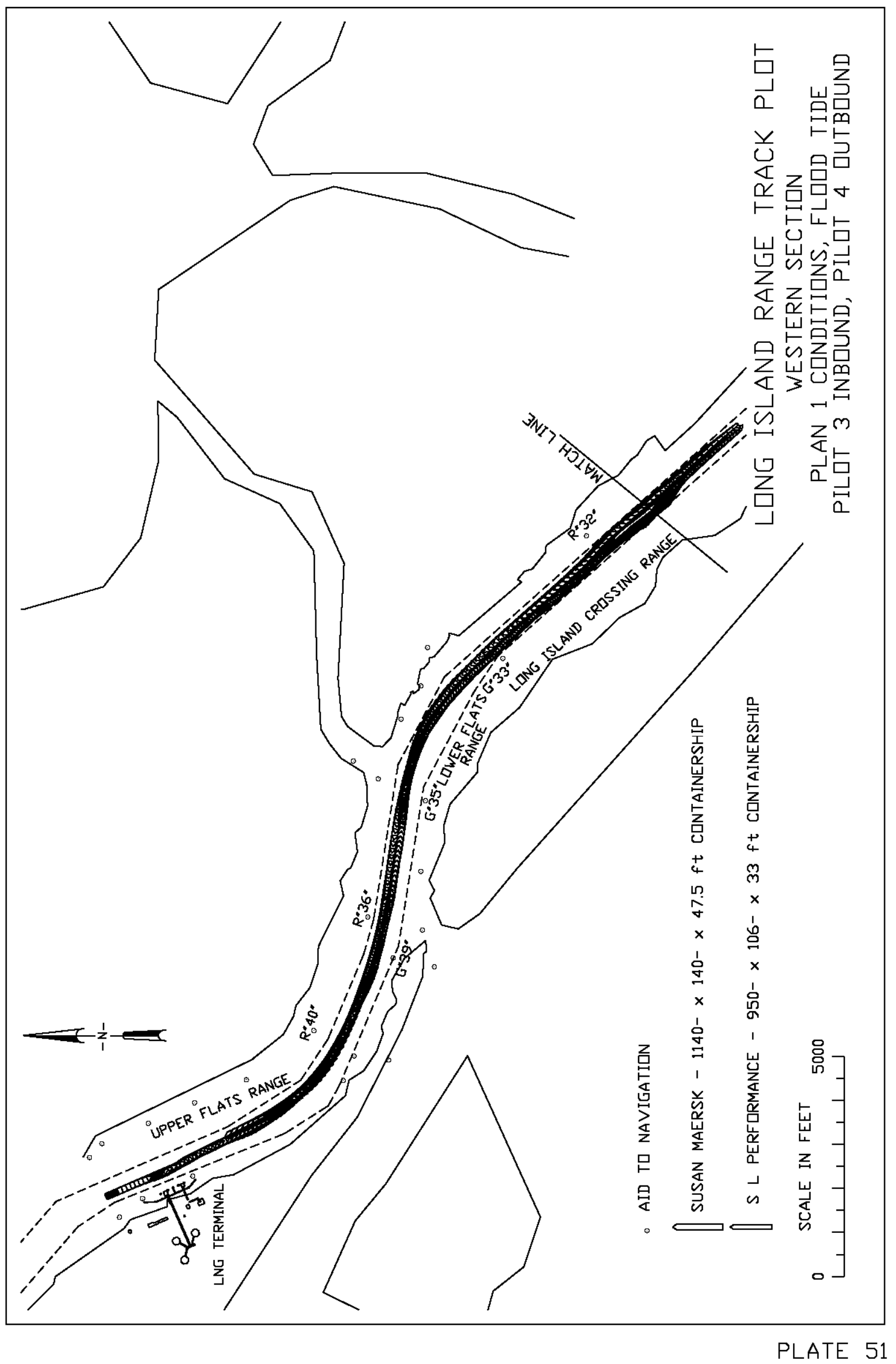




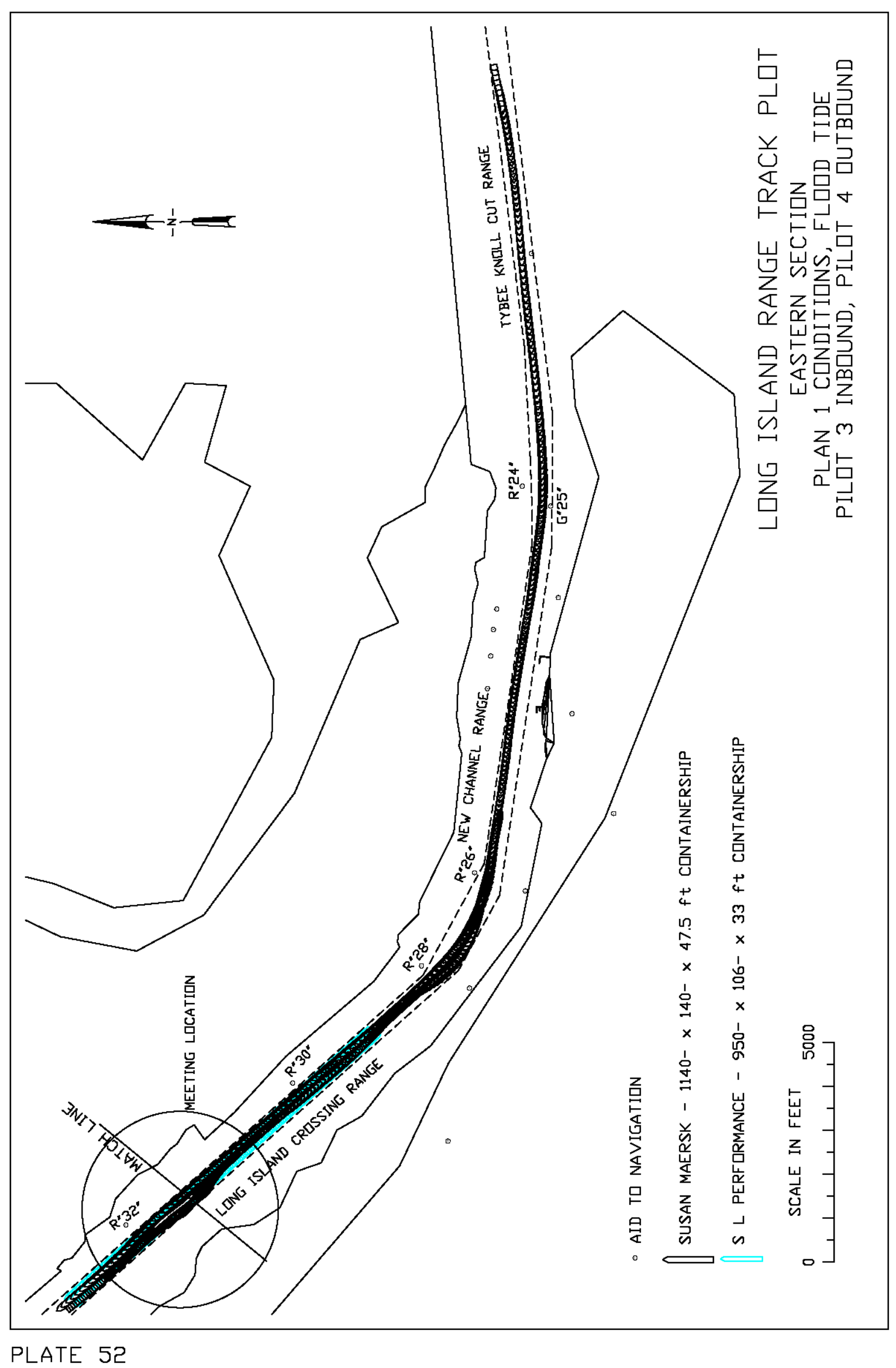




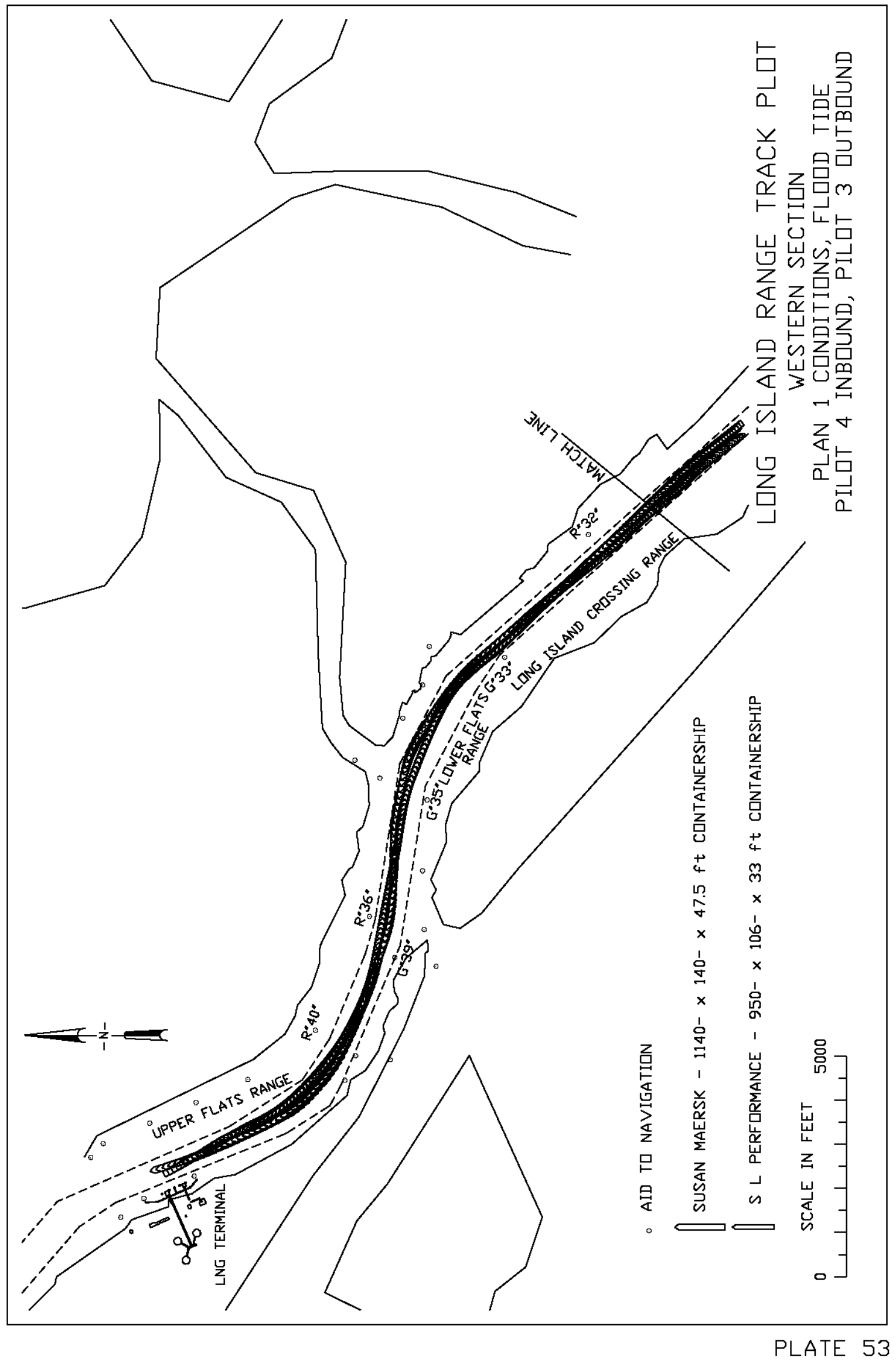




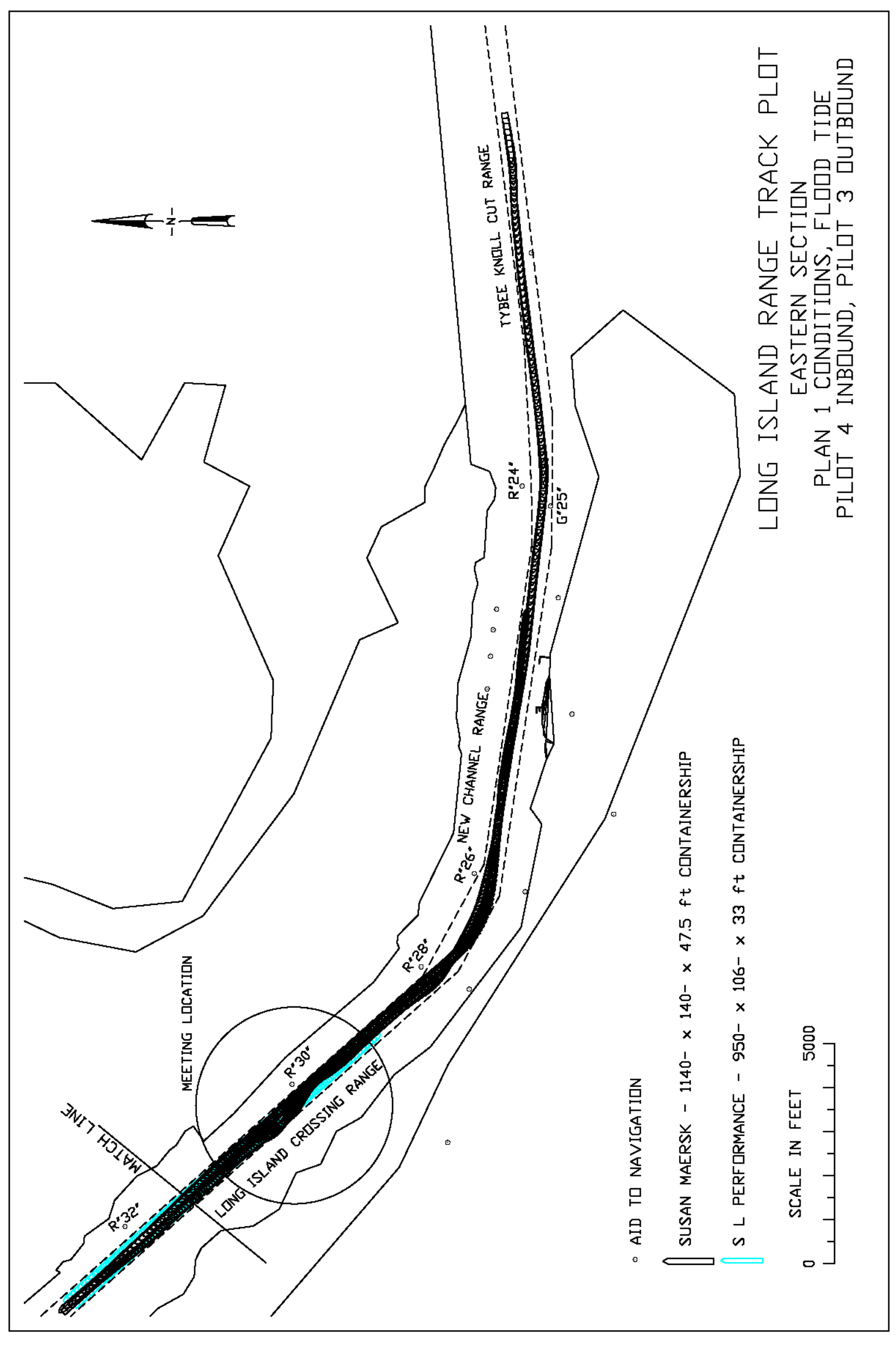

PLATE 54 


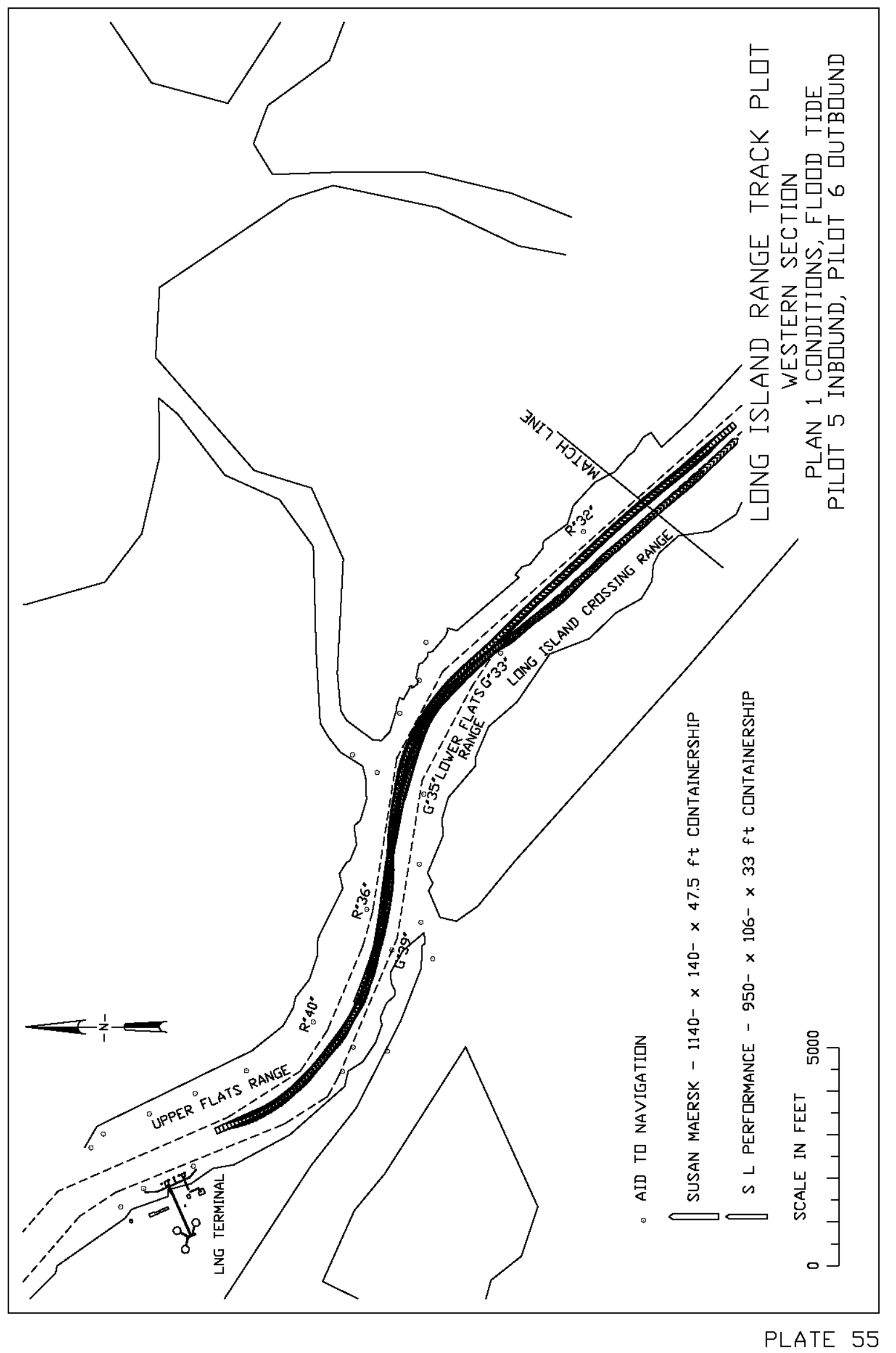




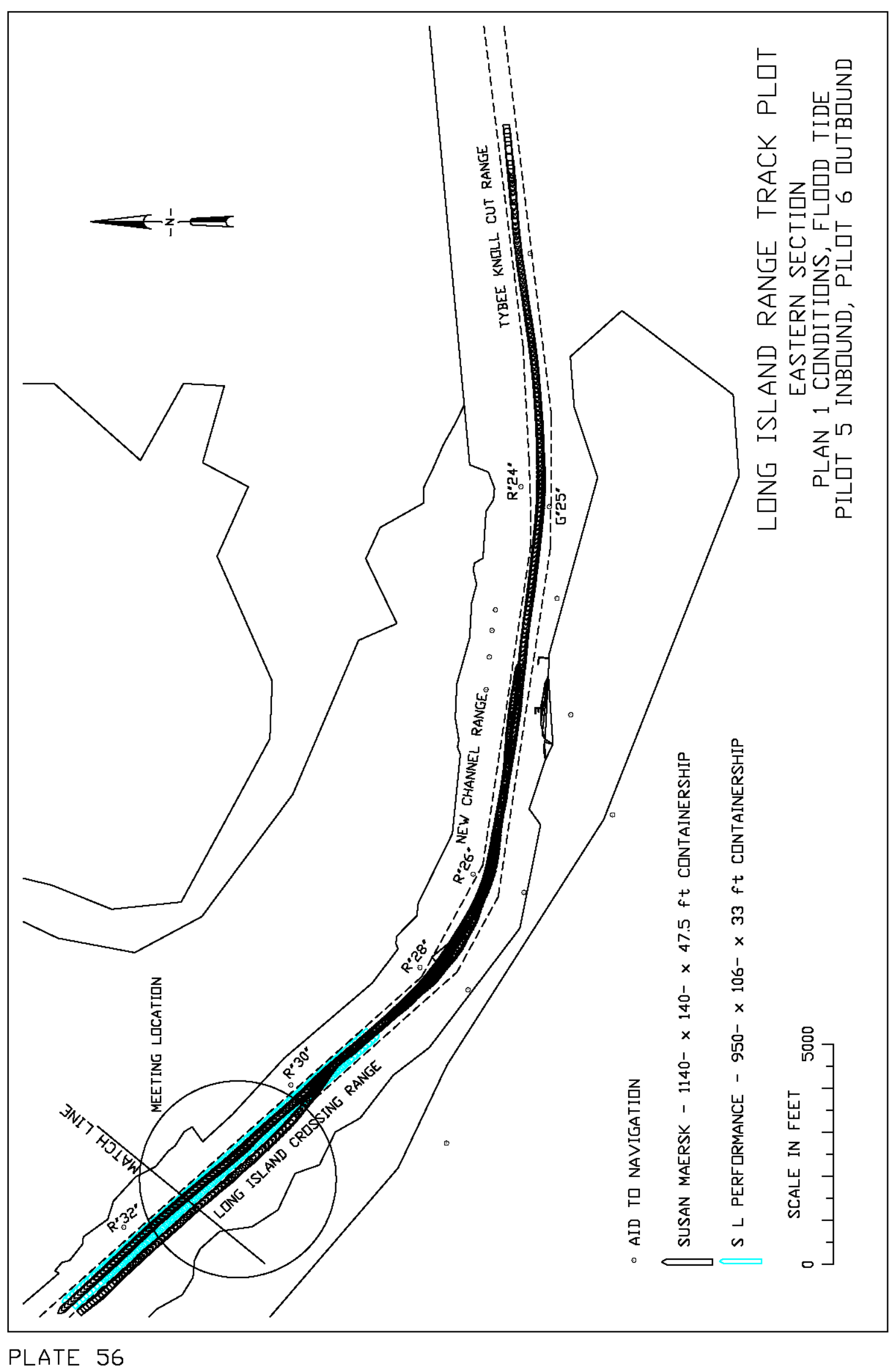




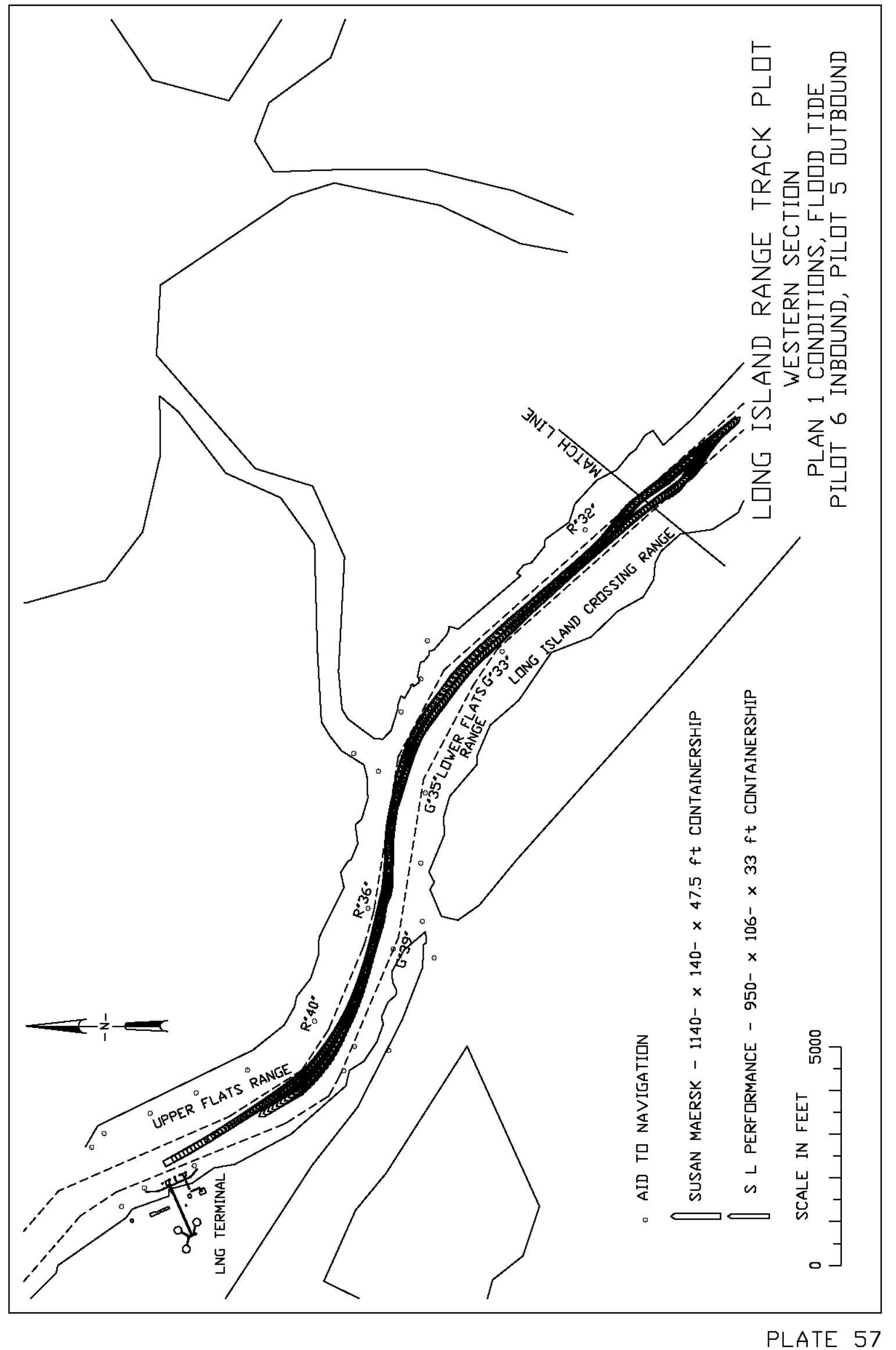




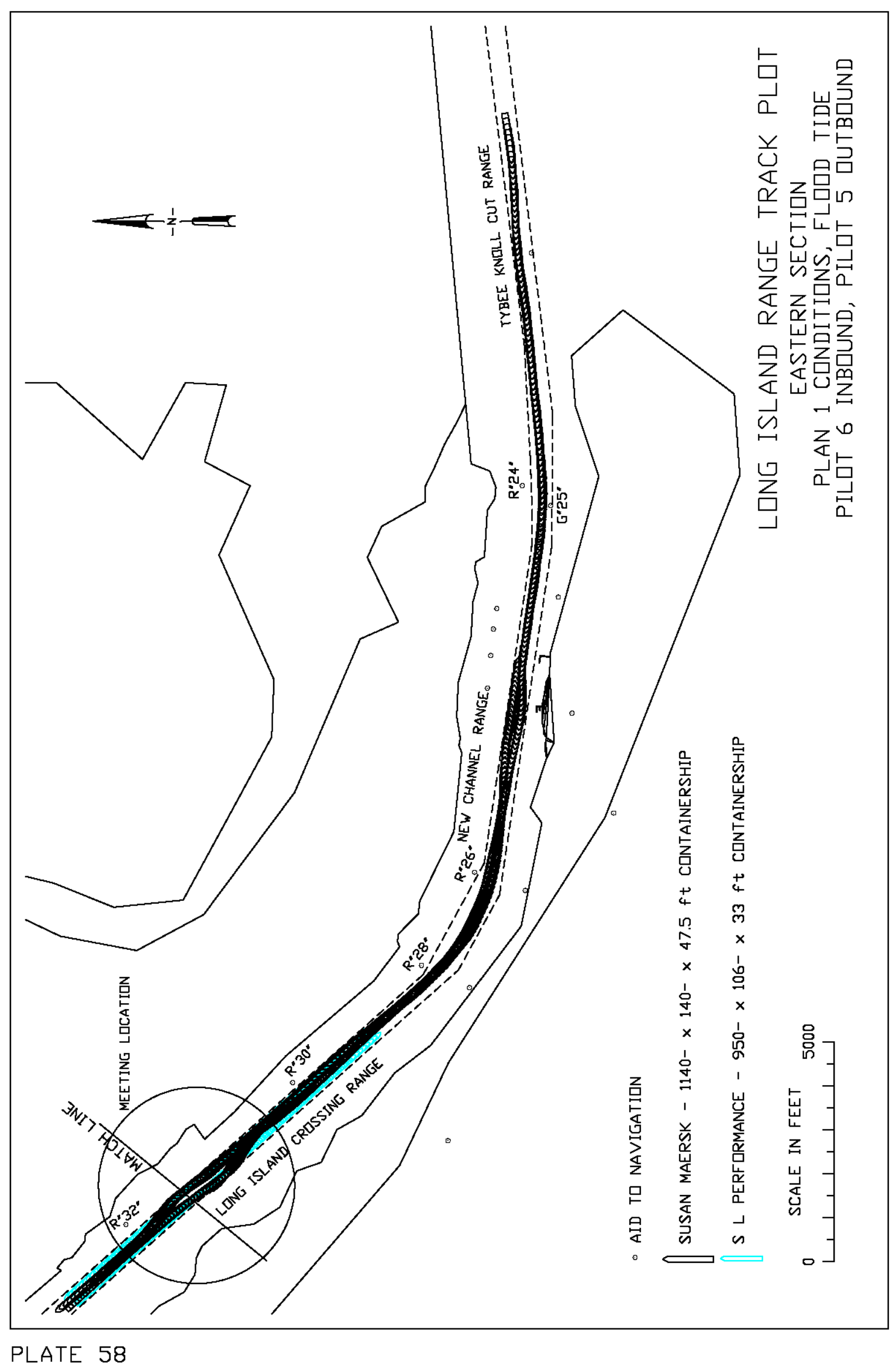




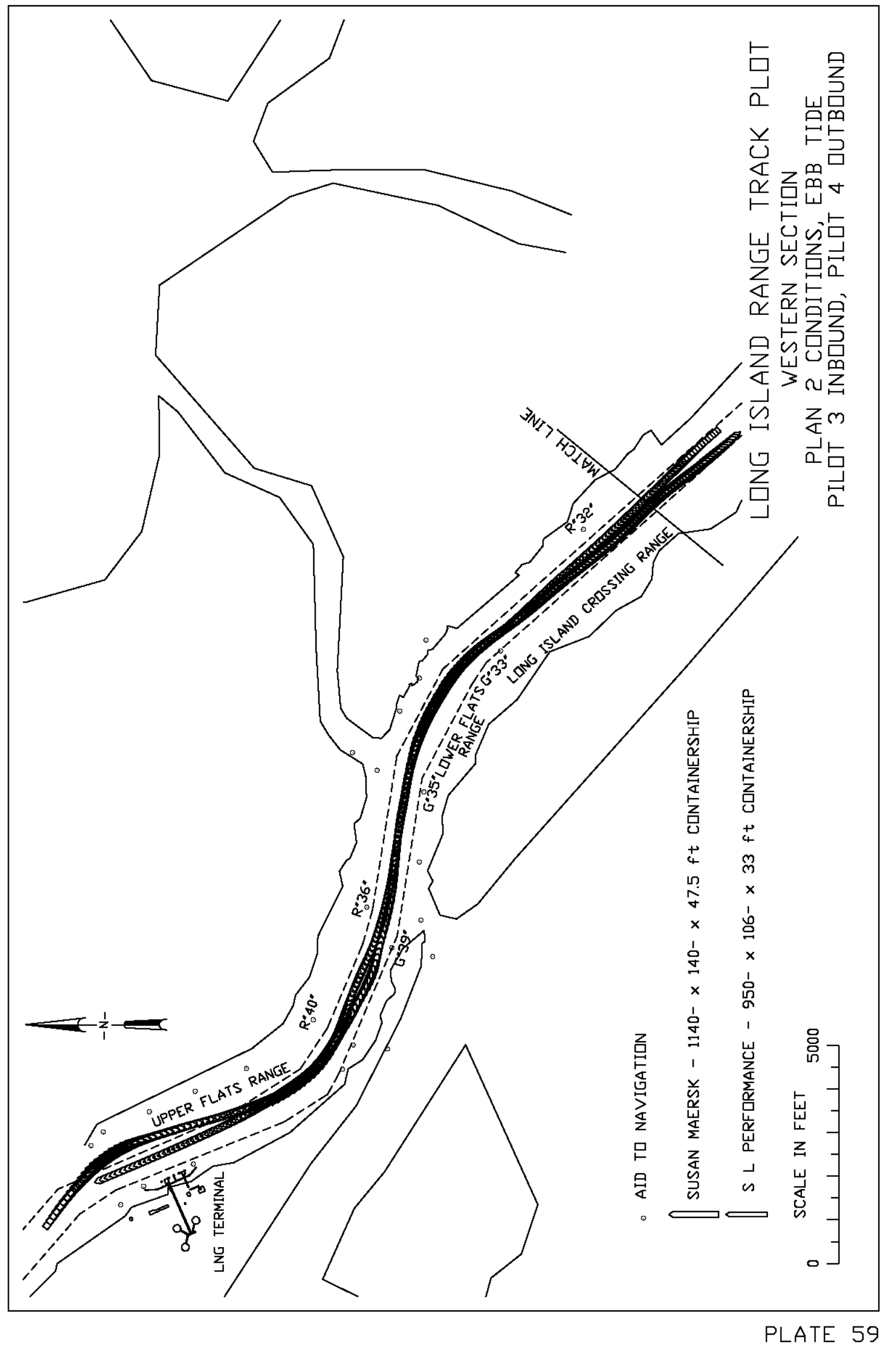




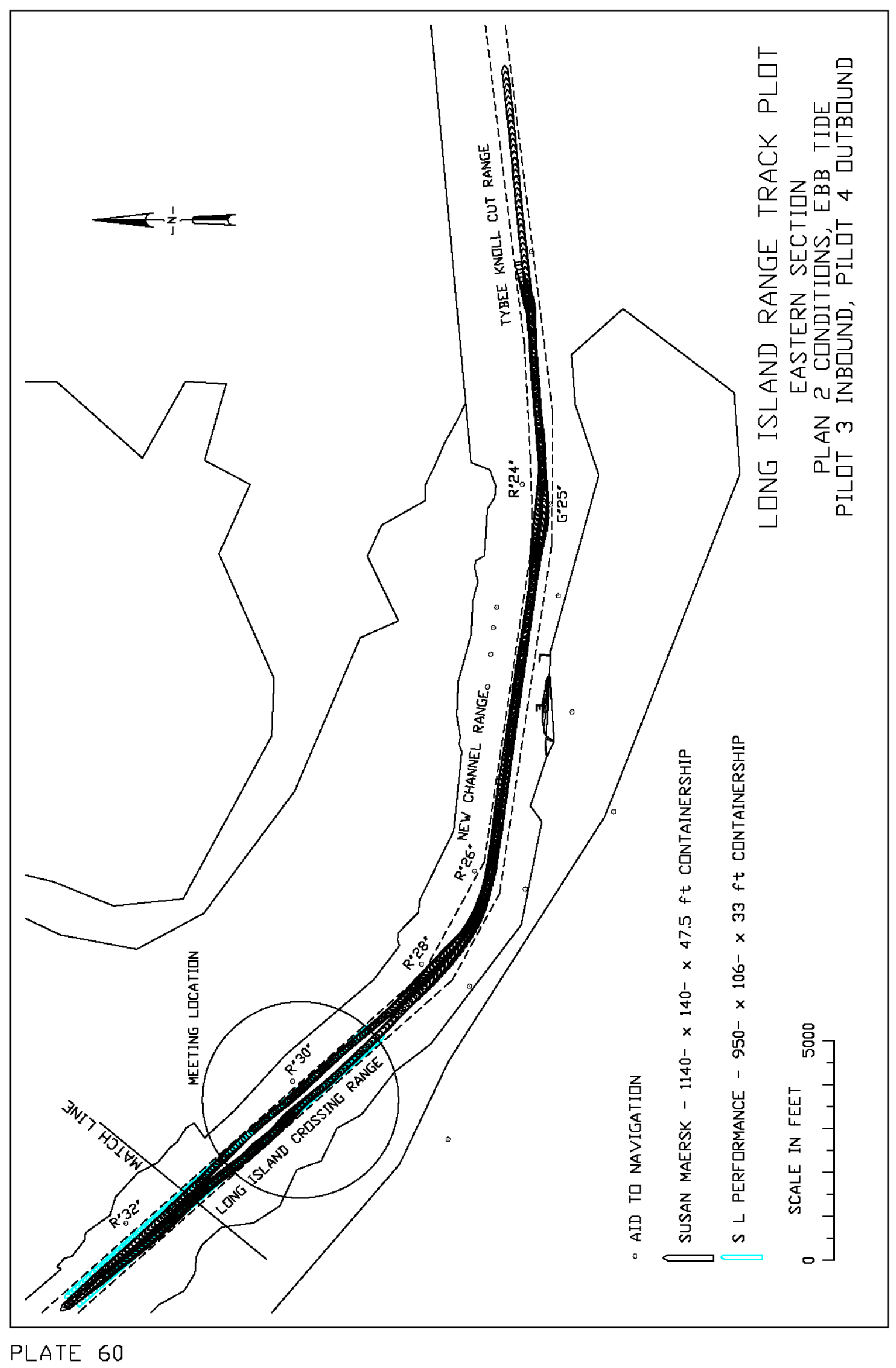




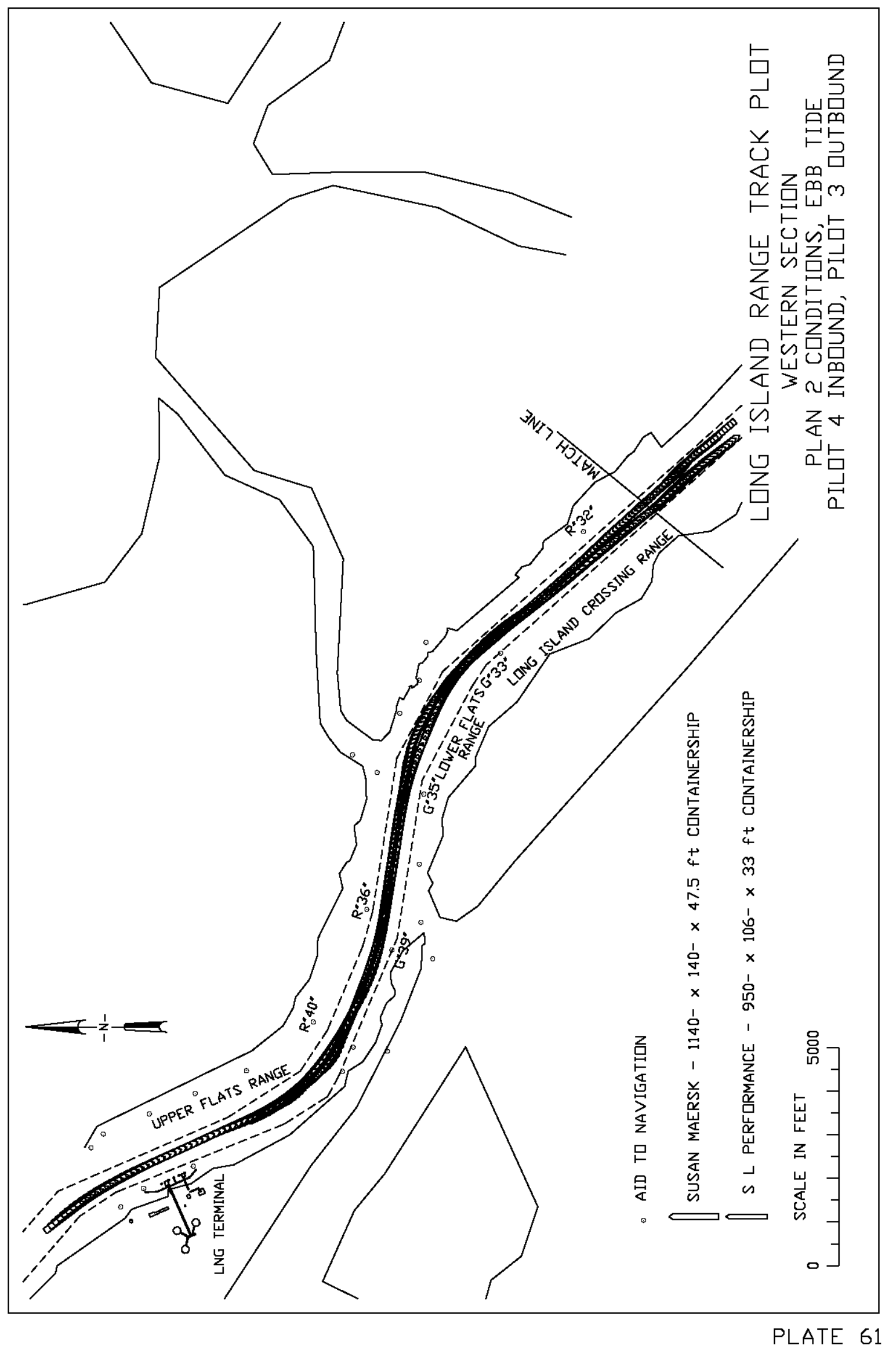




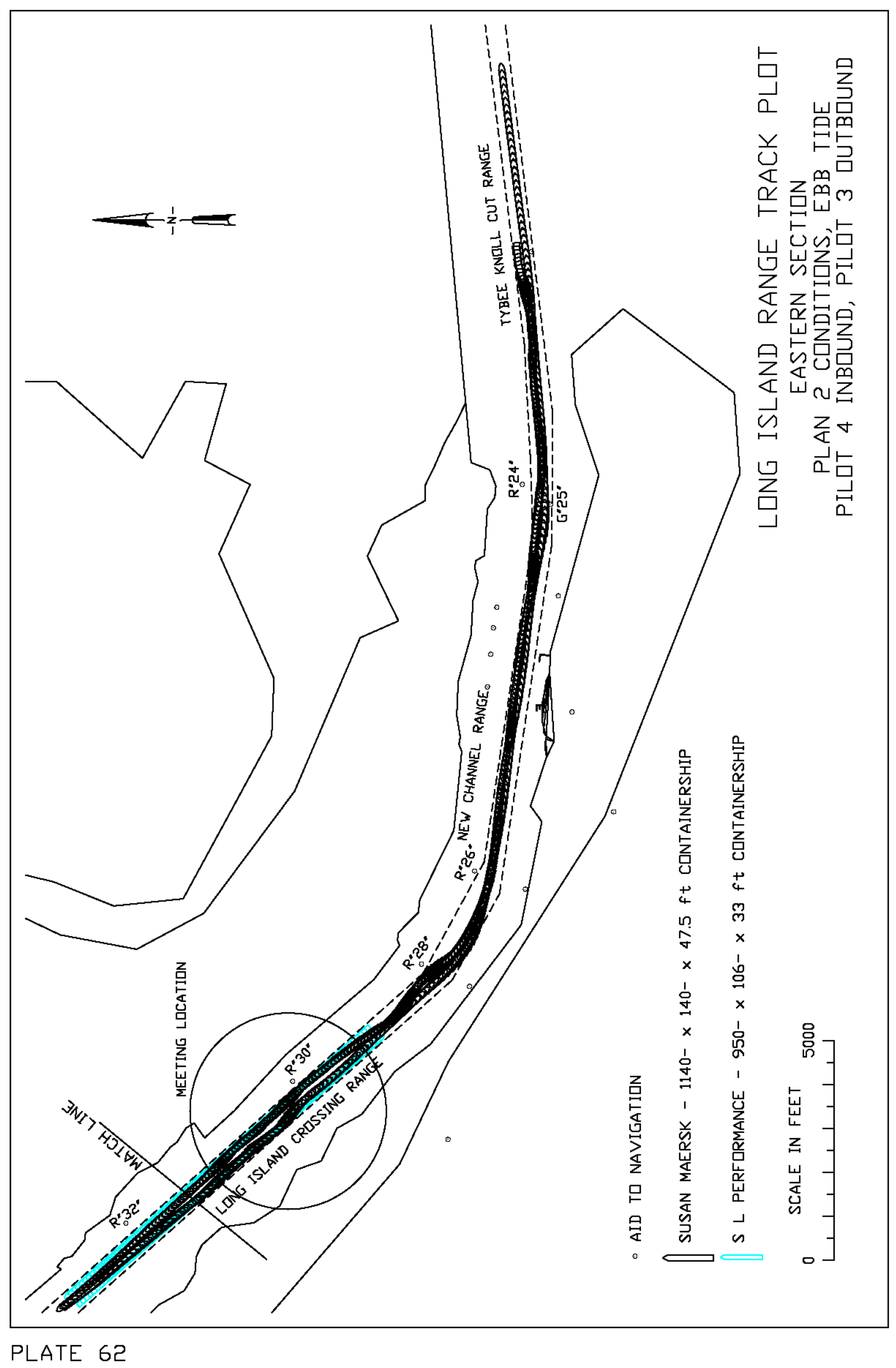




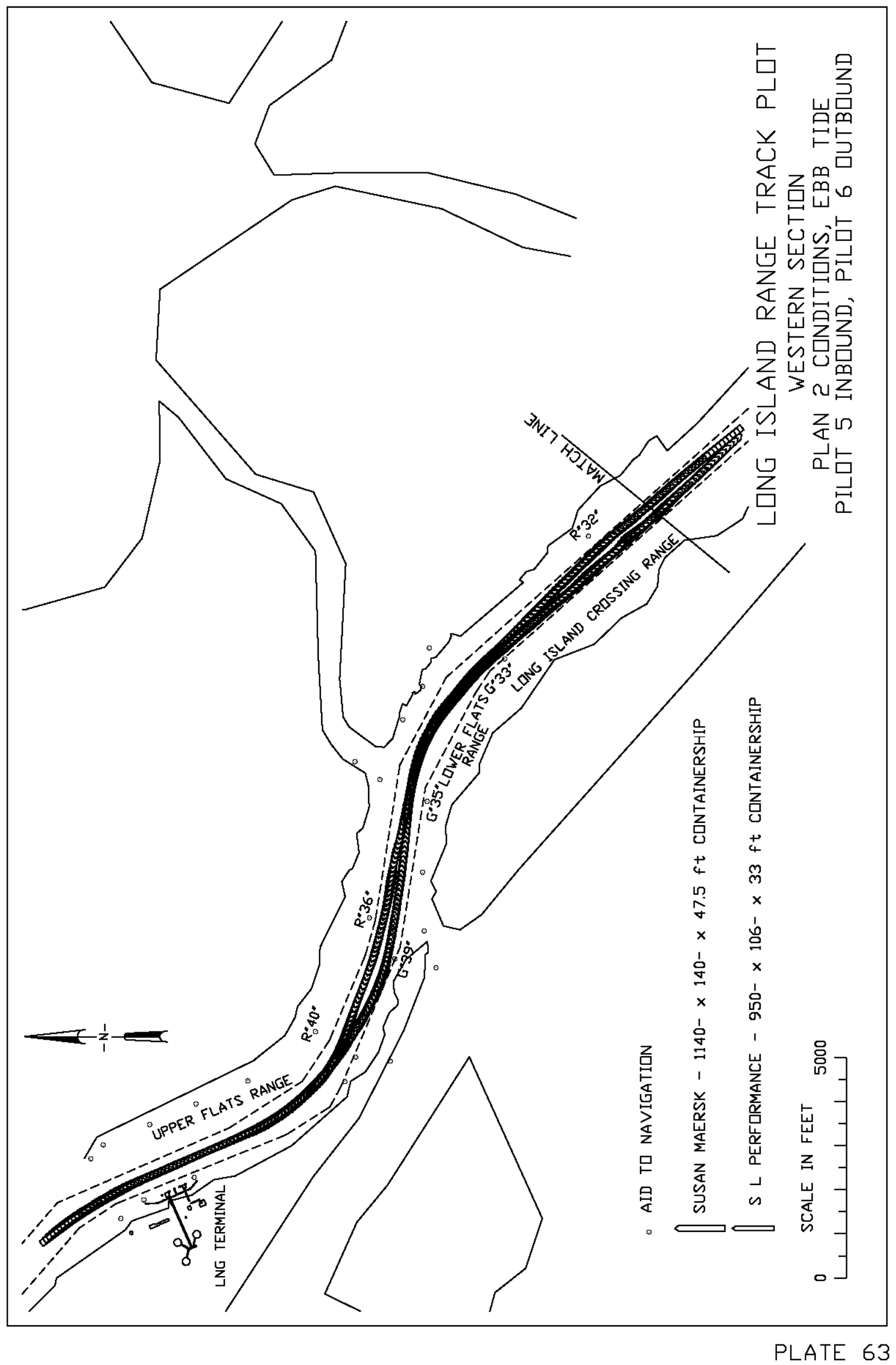




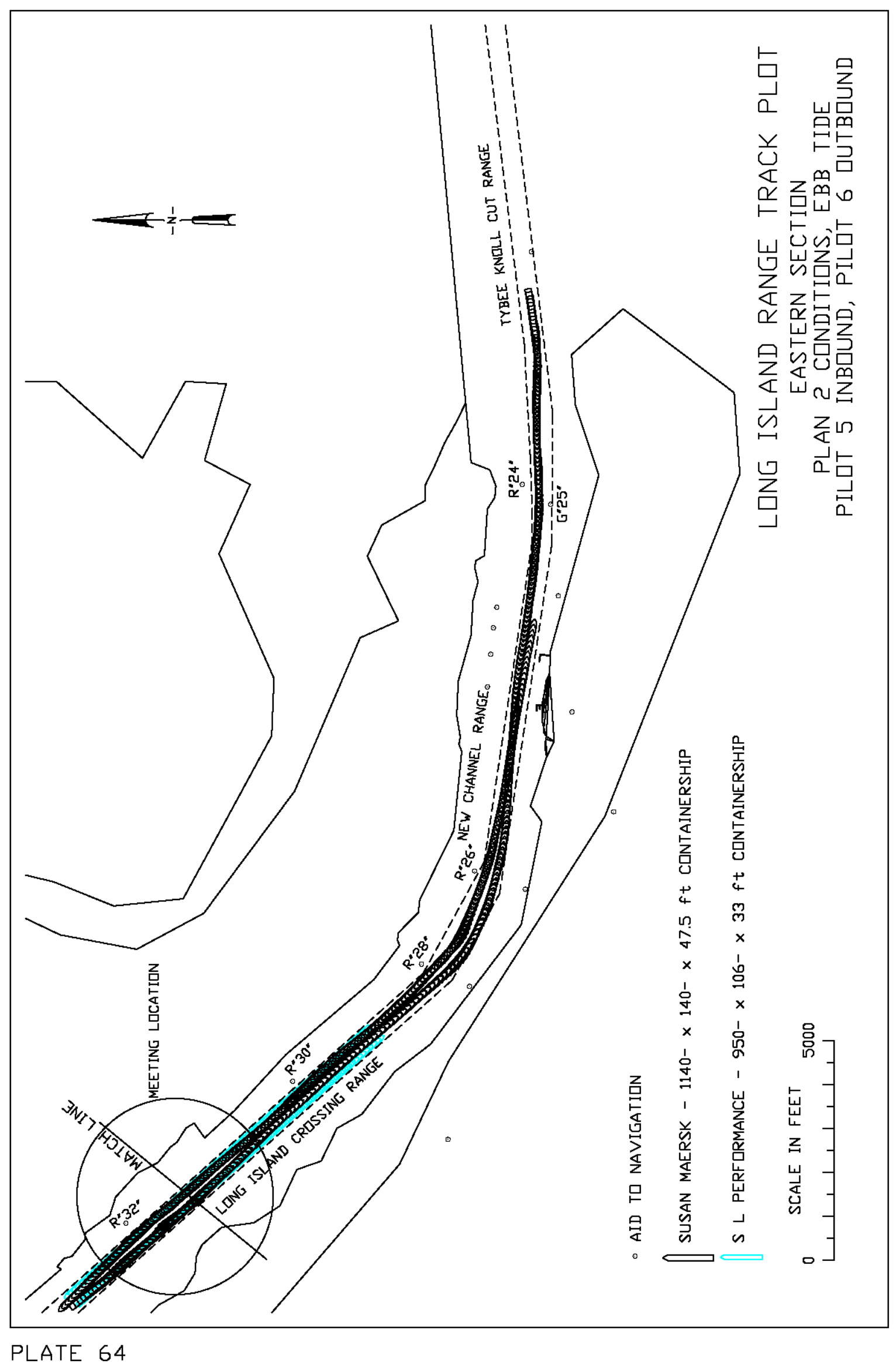




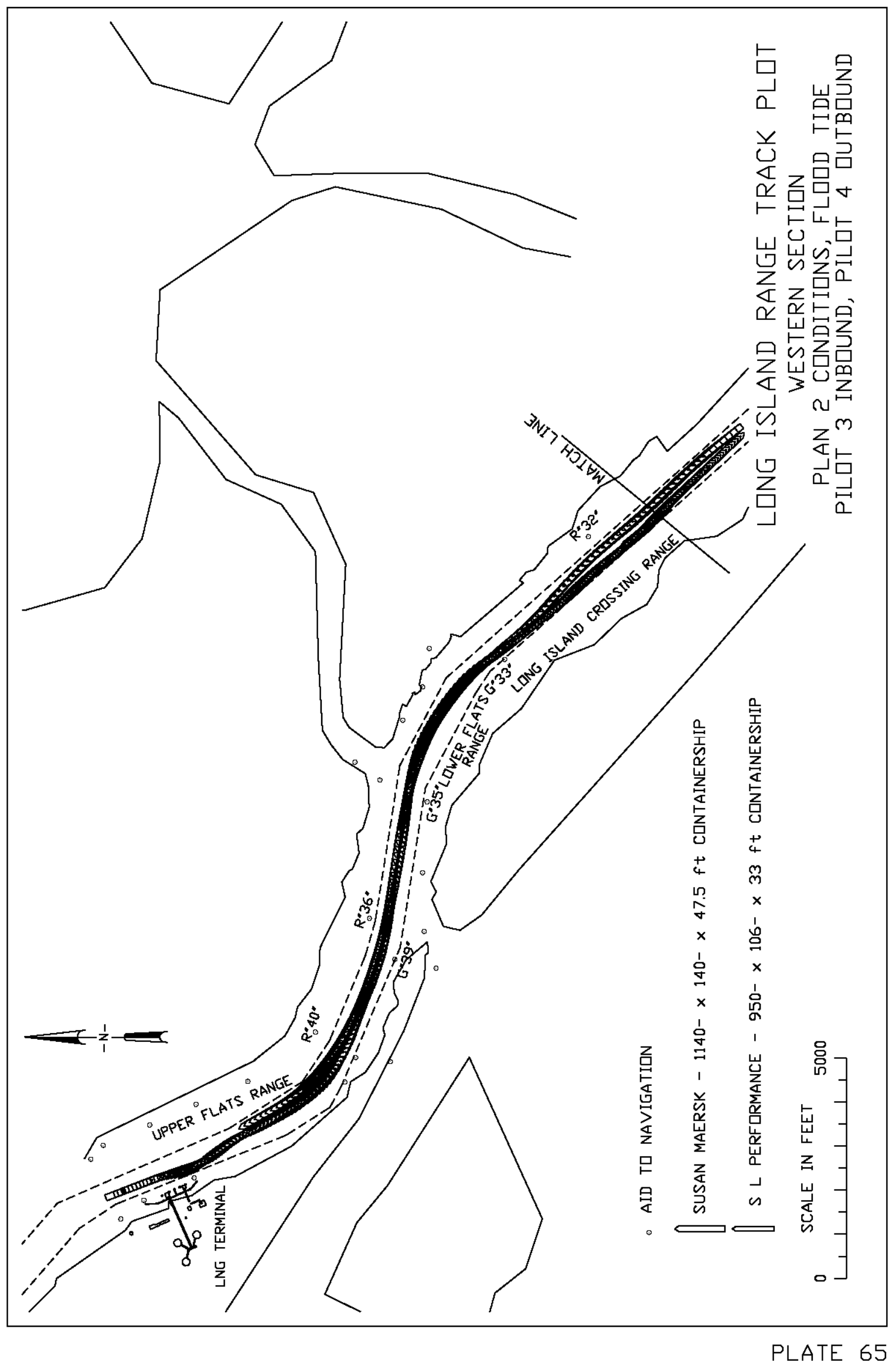




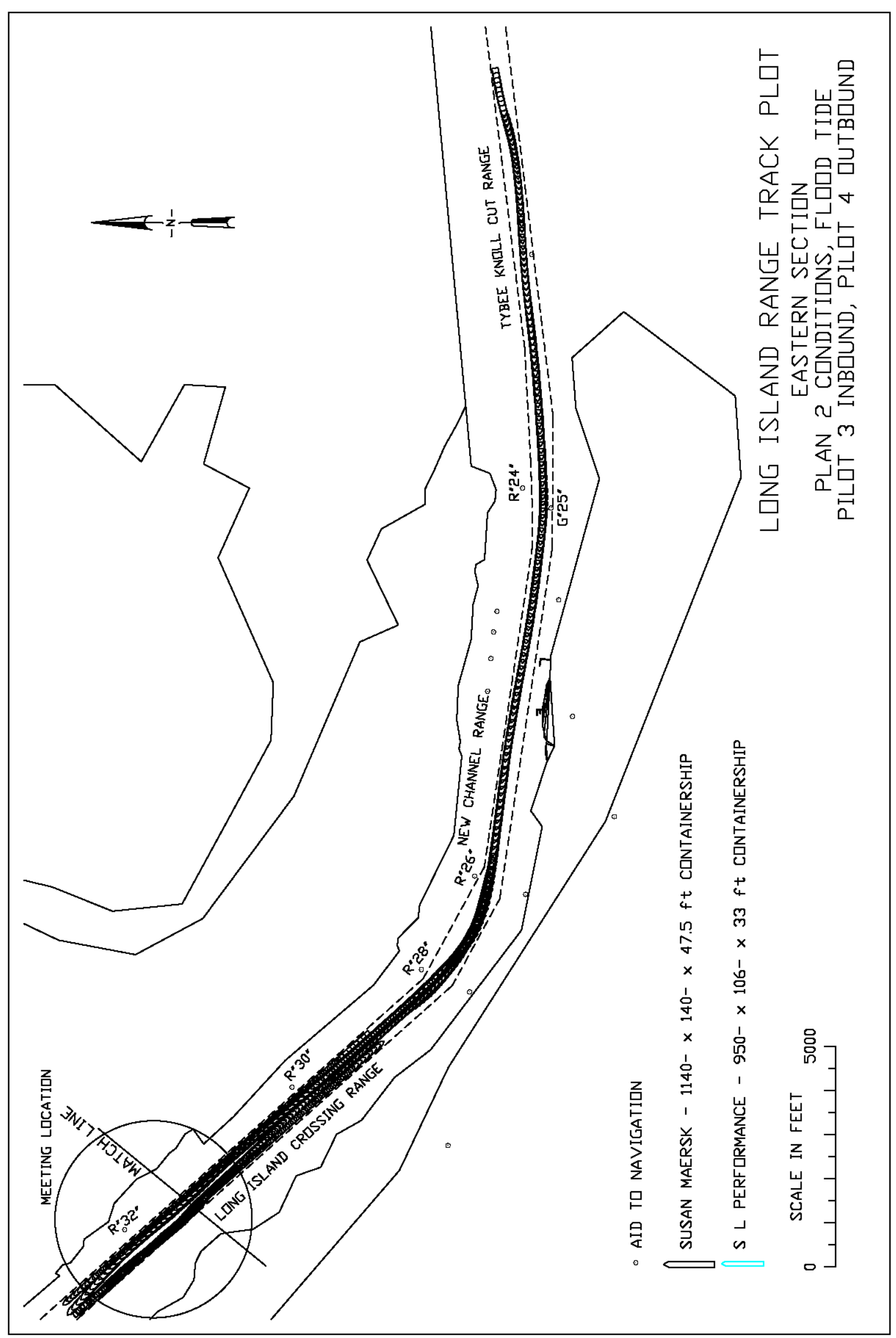

PLATE 66 


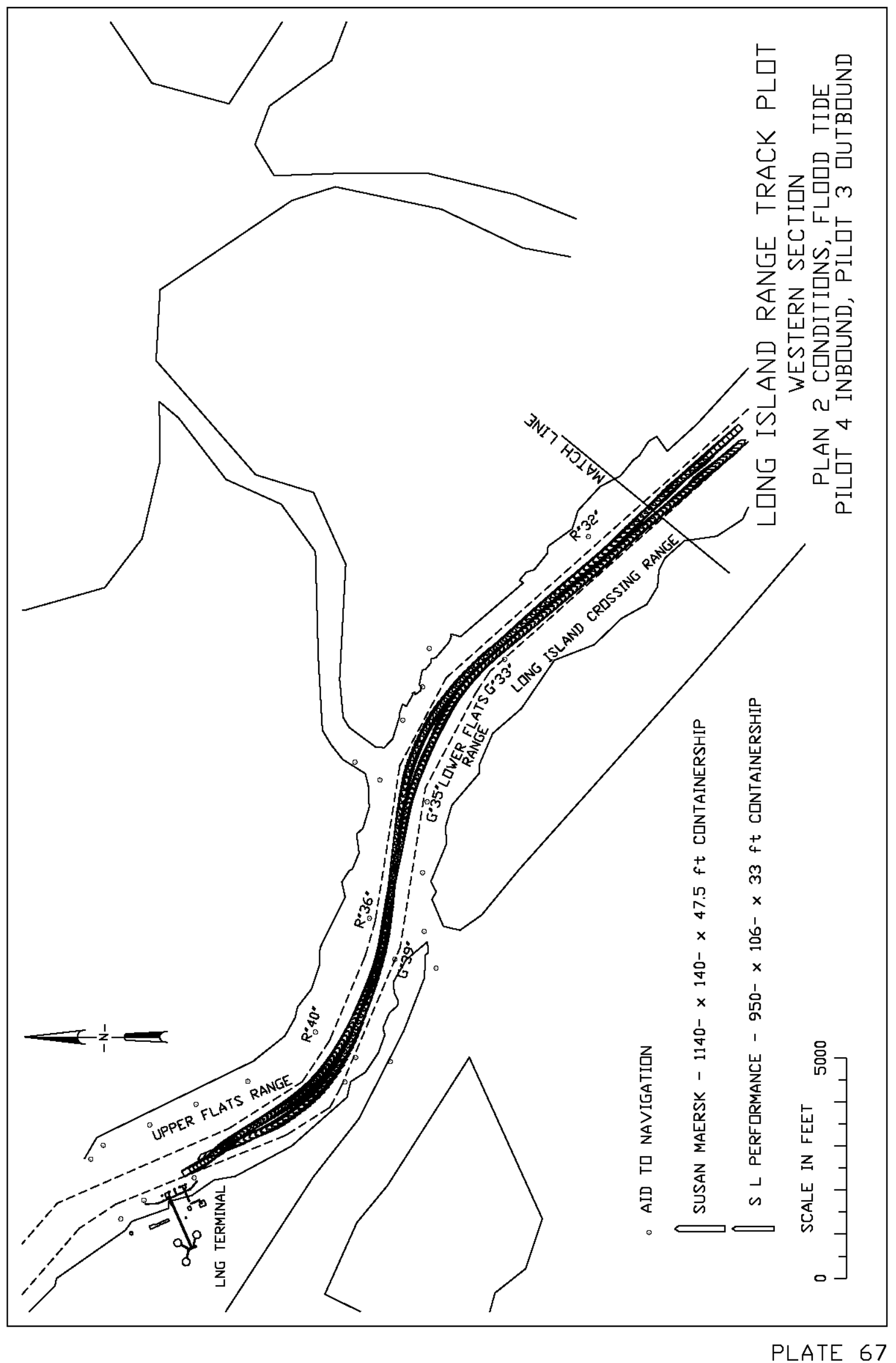




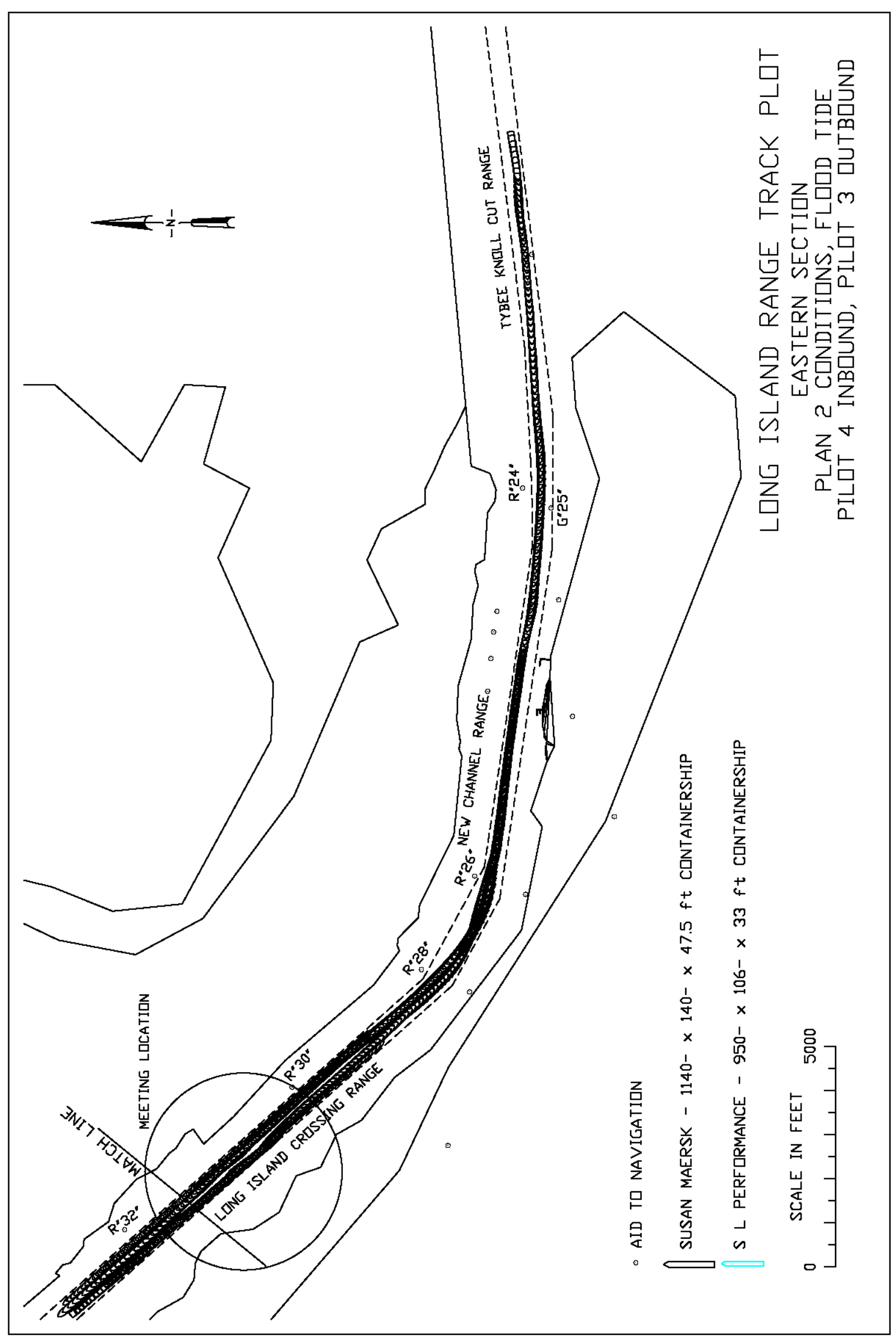

PLATE 68 


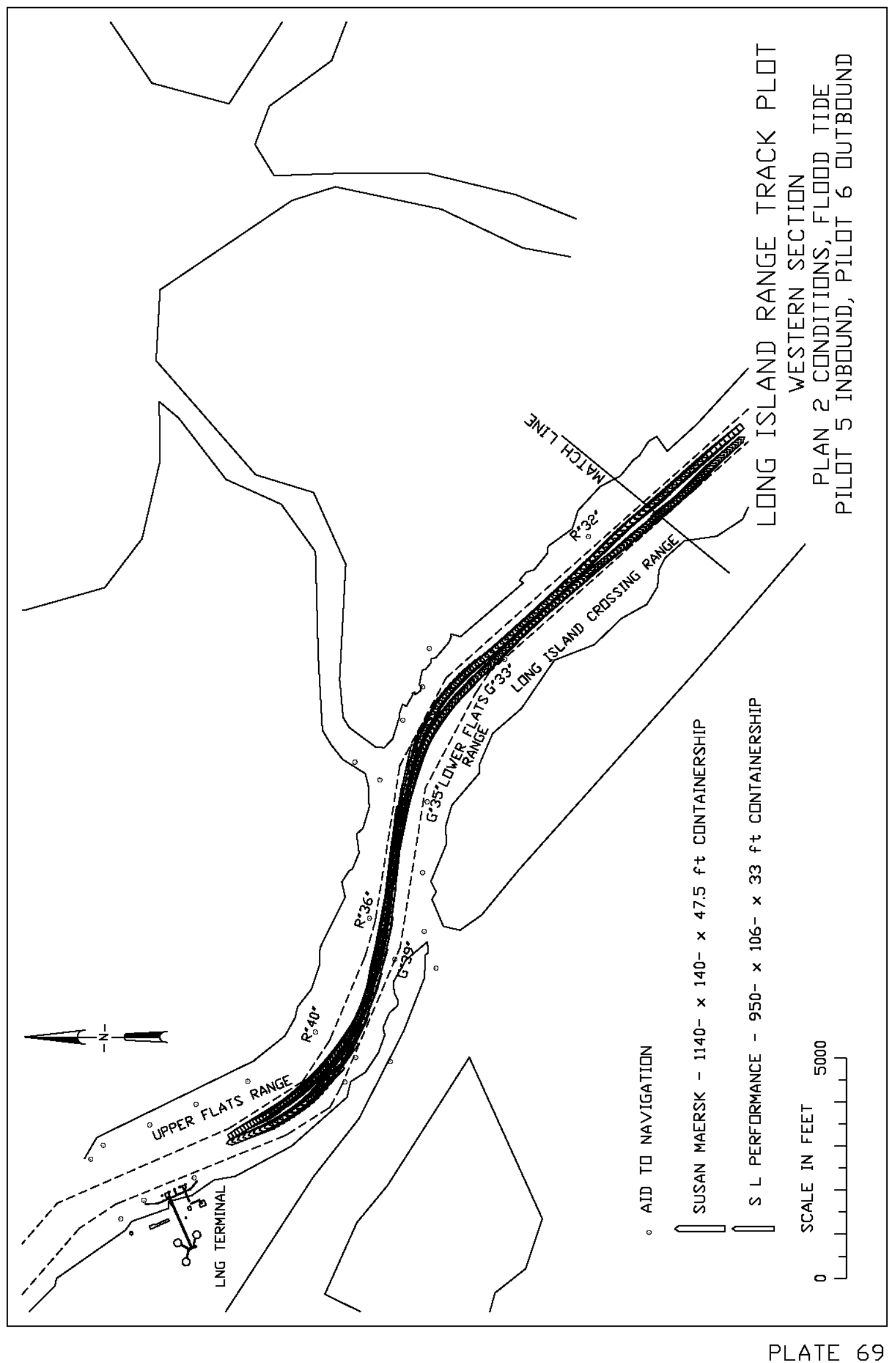




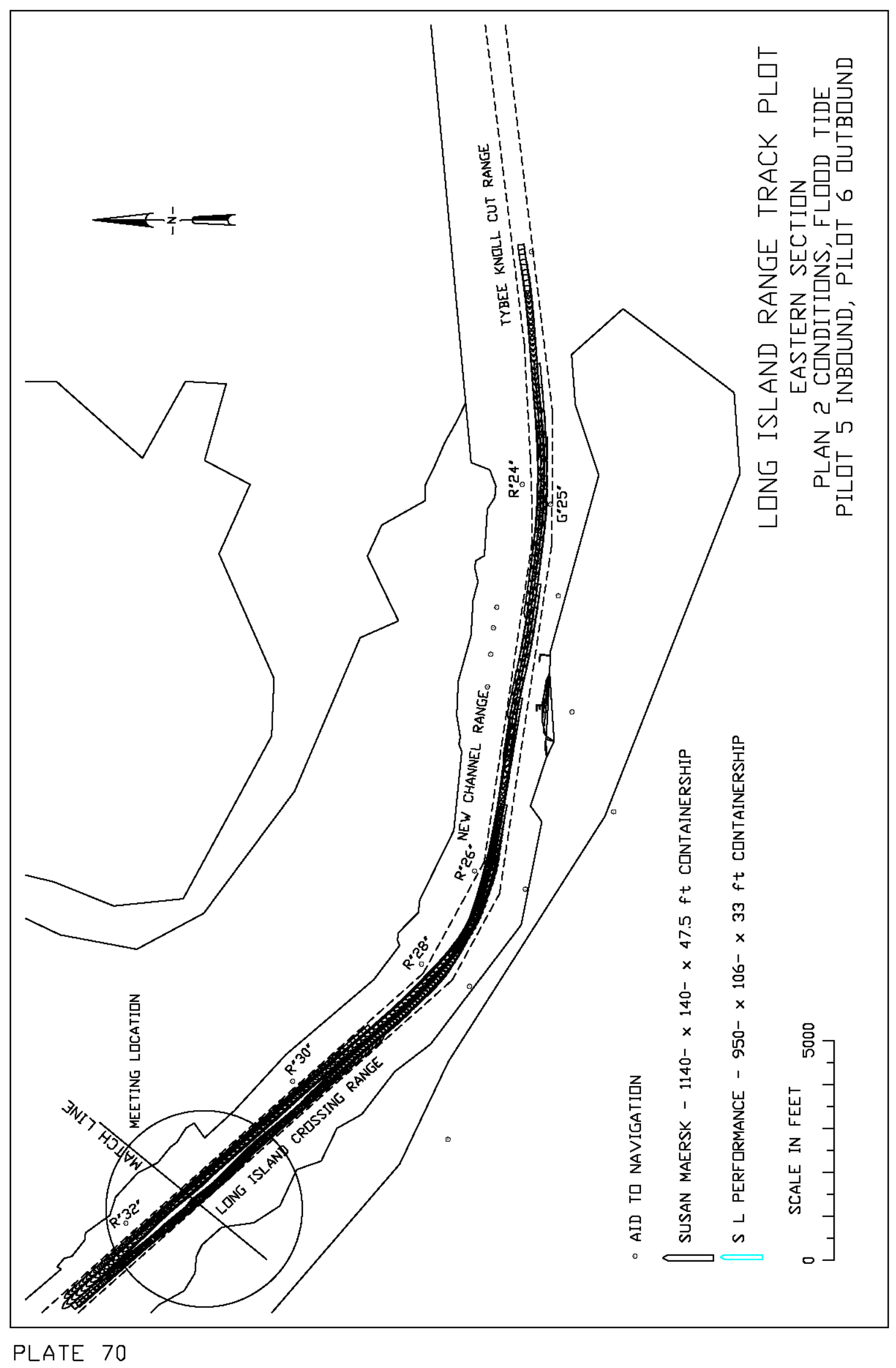




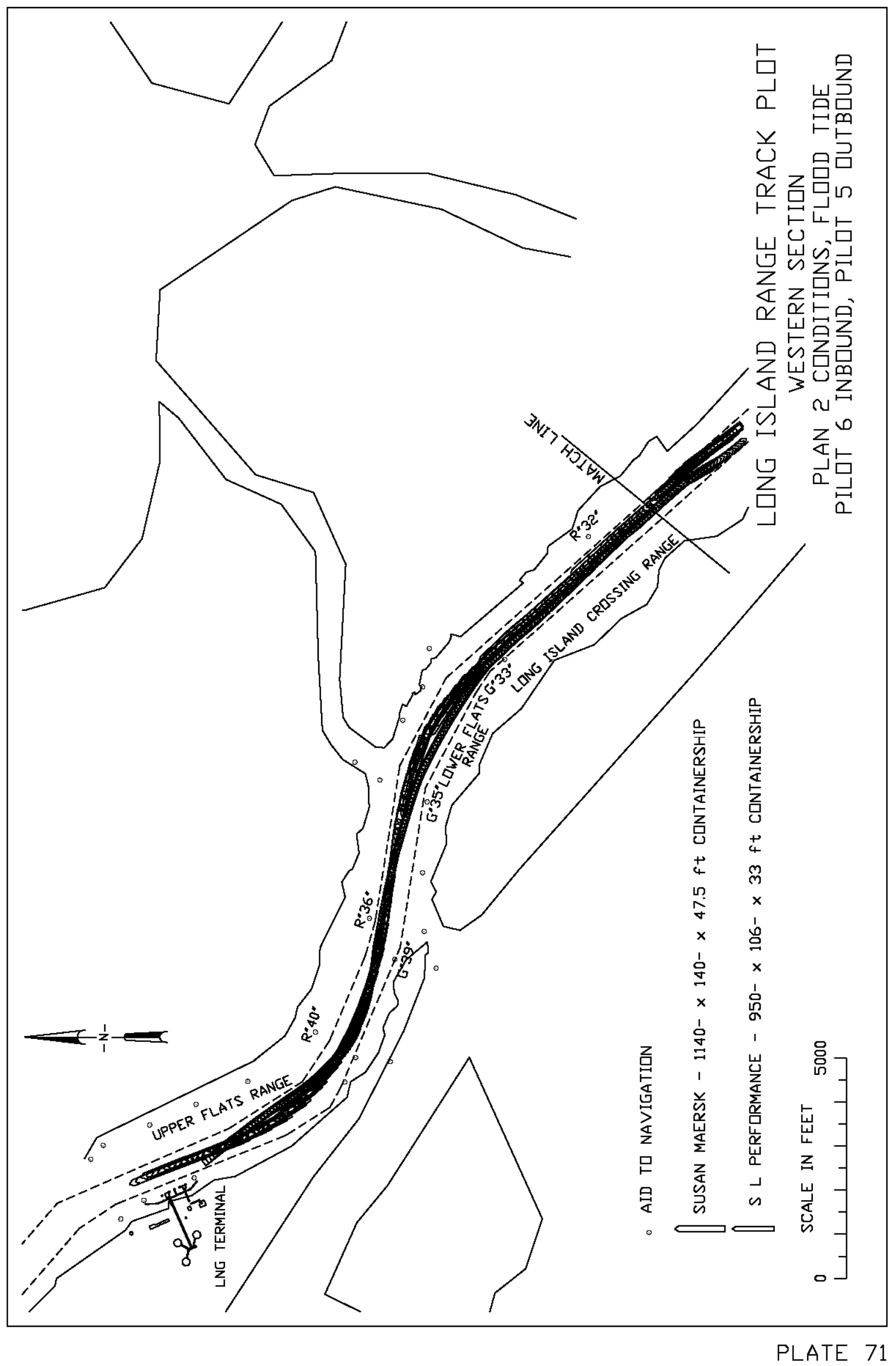




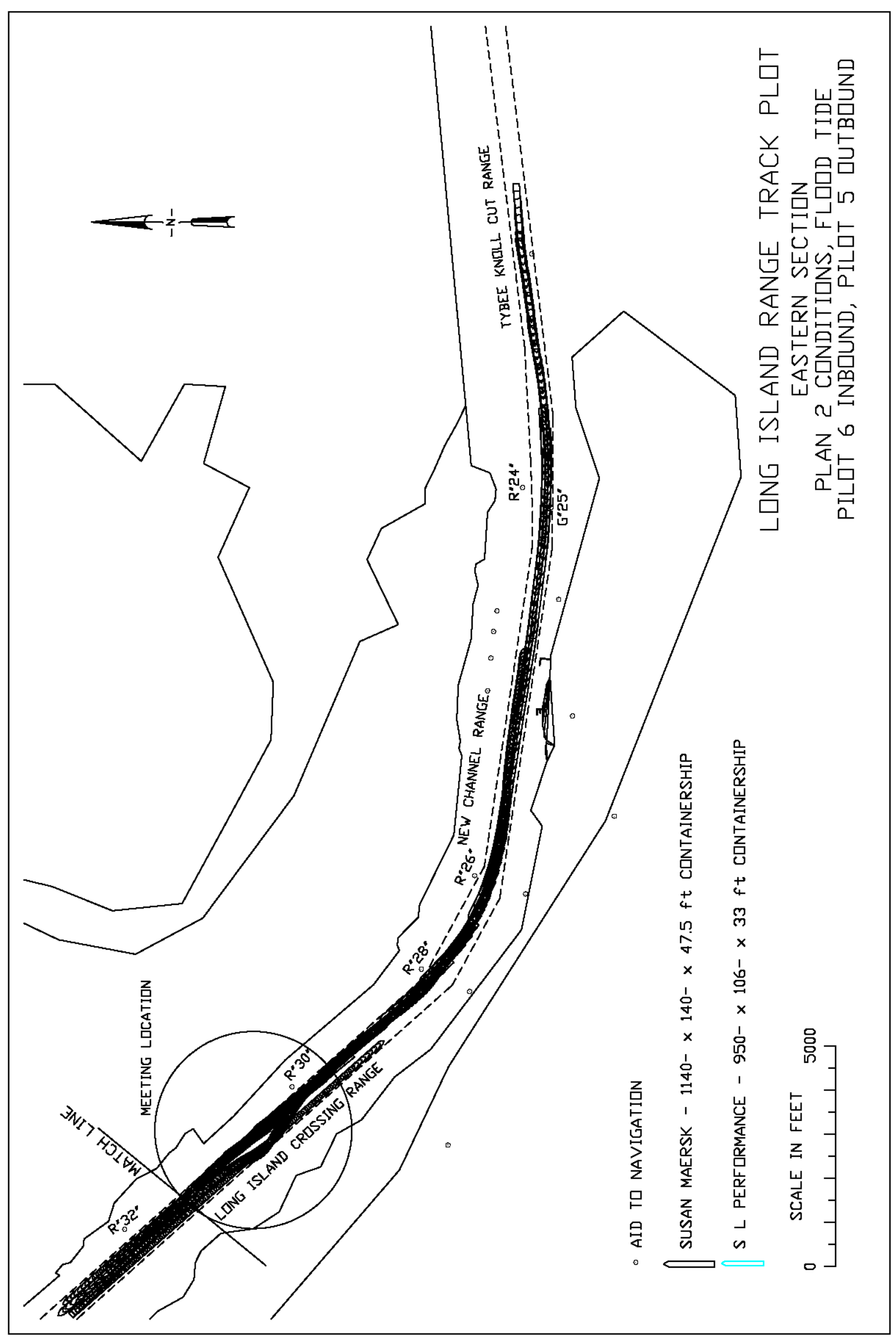

PLATE 72 


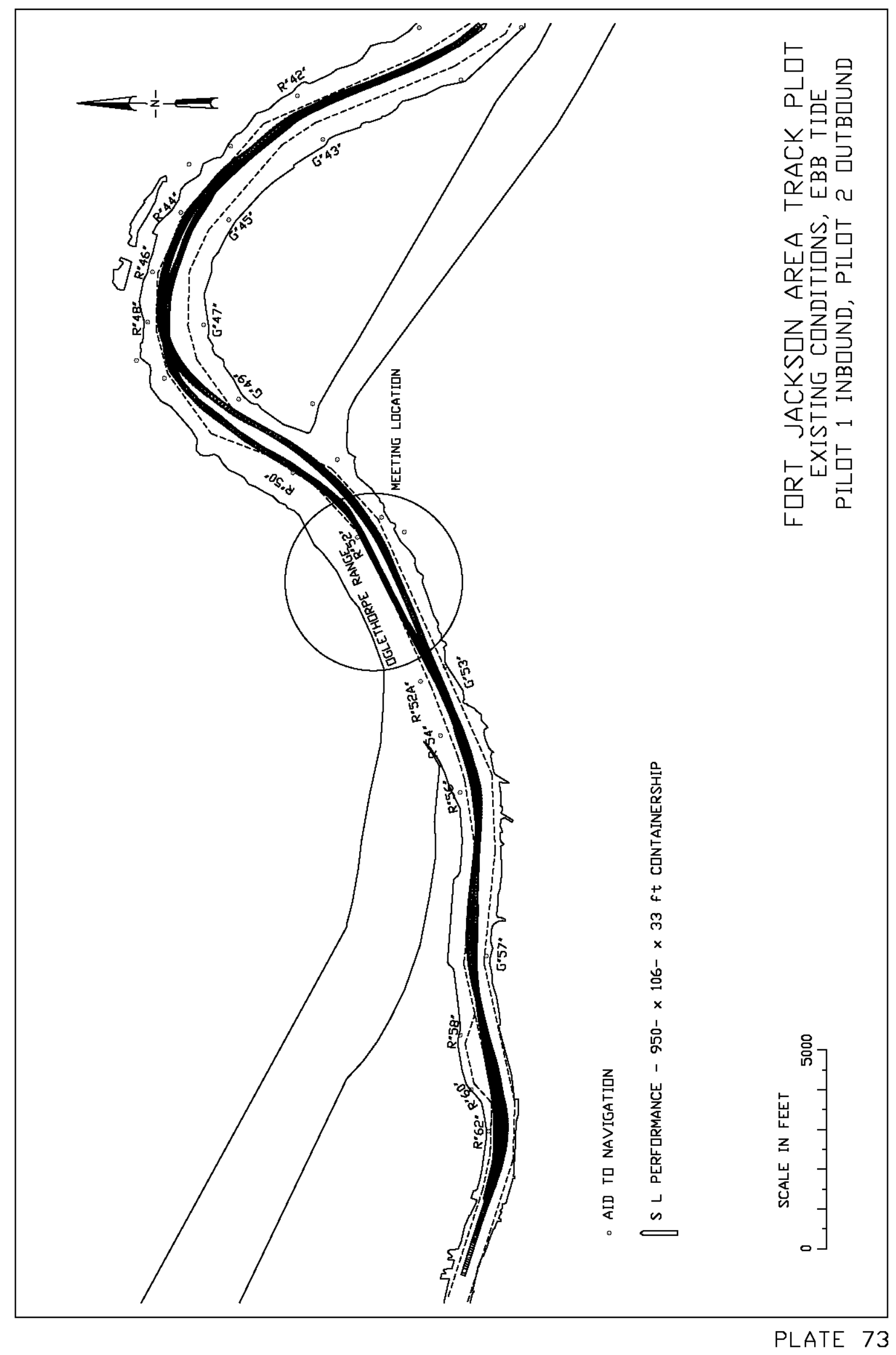




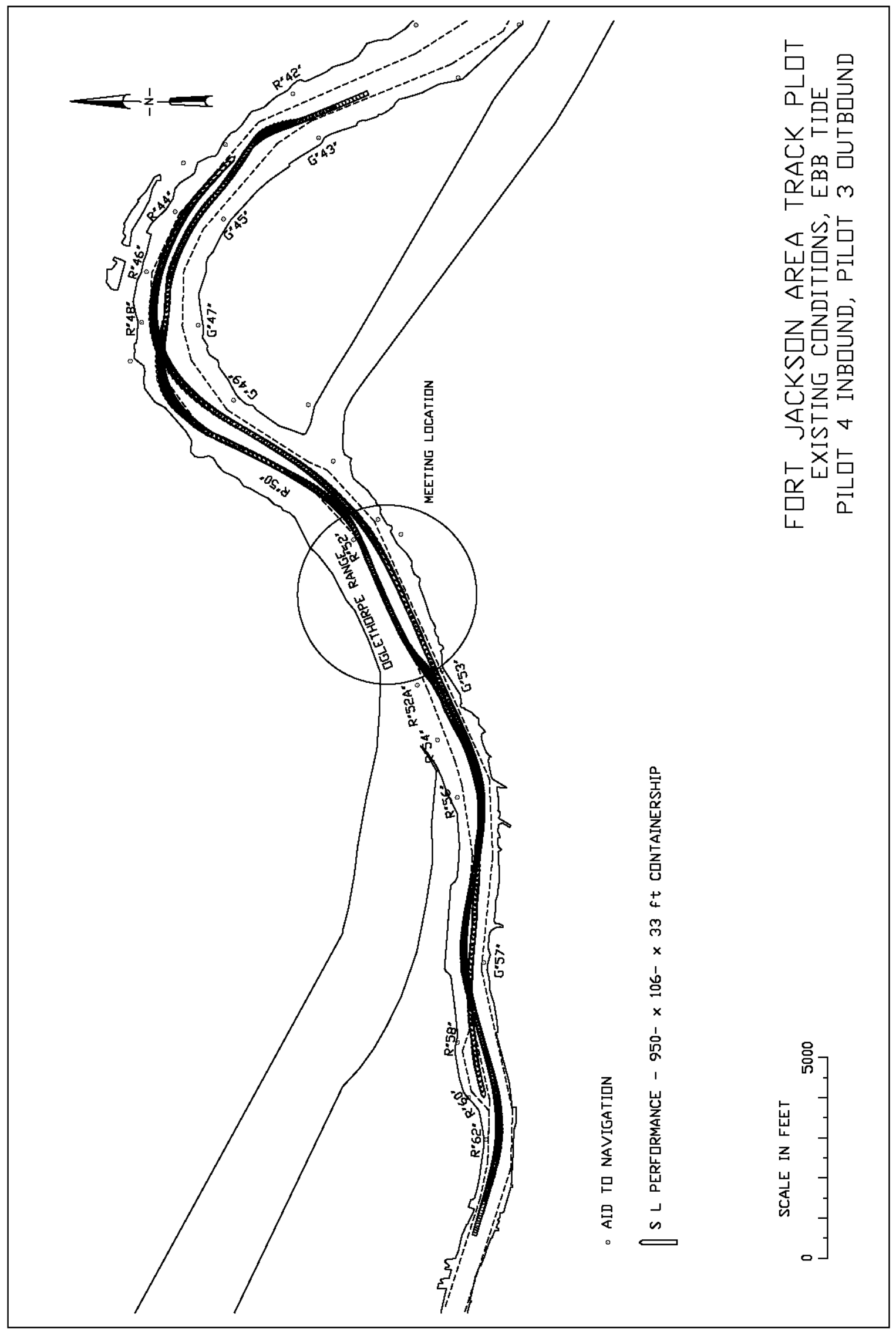

PLATE 74 


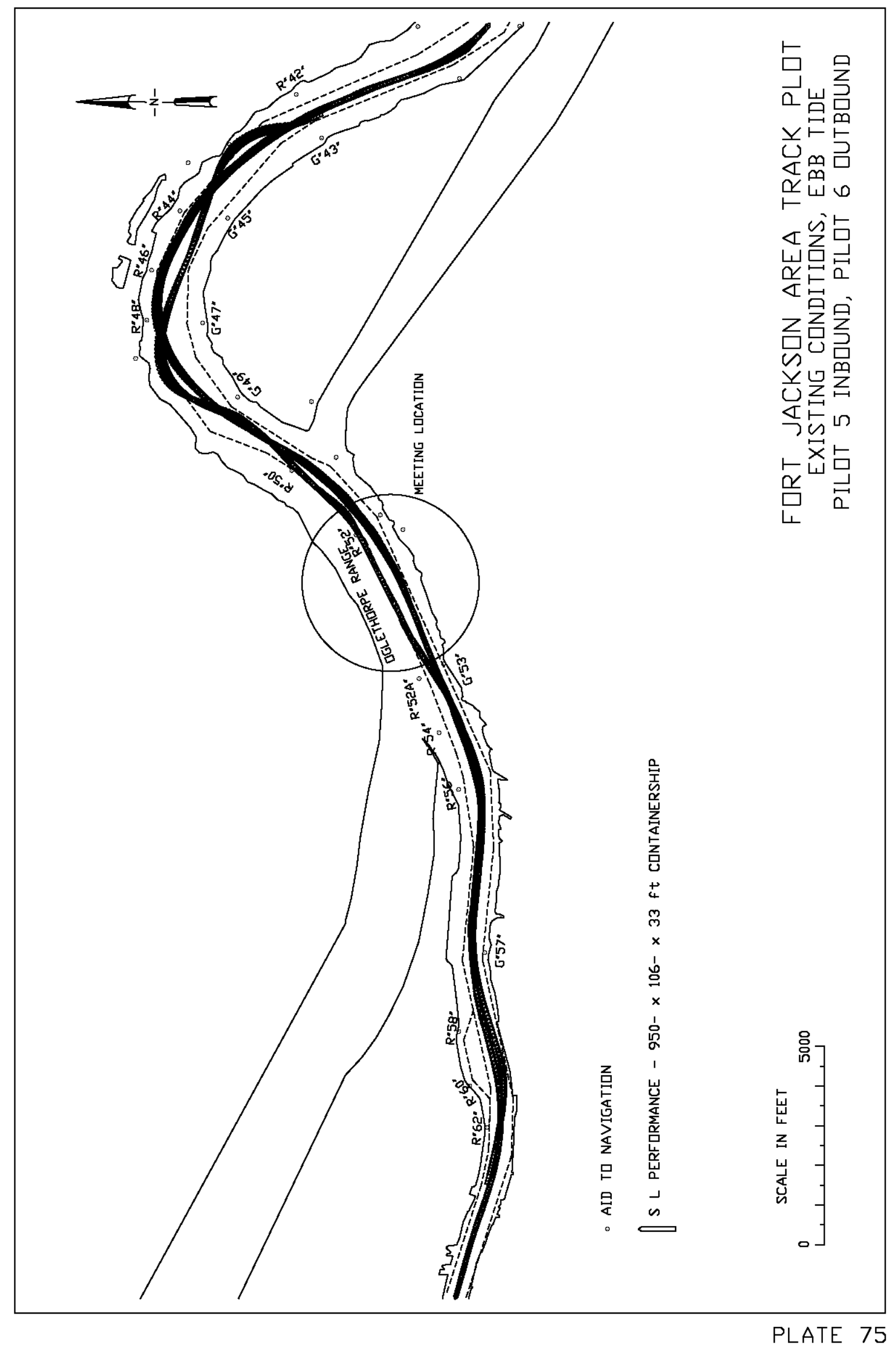




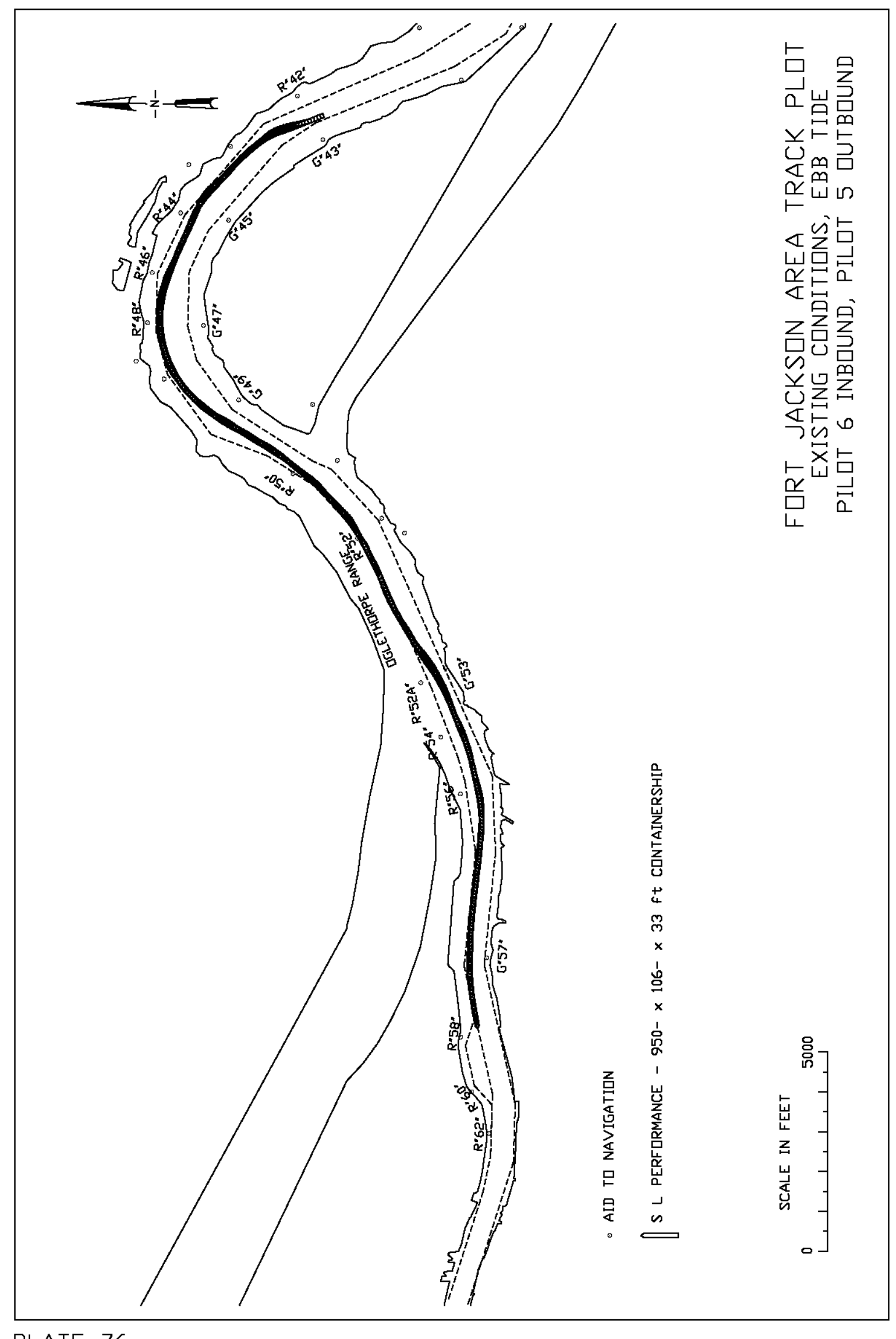

PLATE 76 


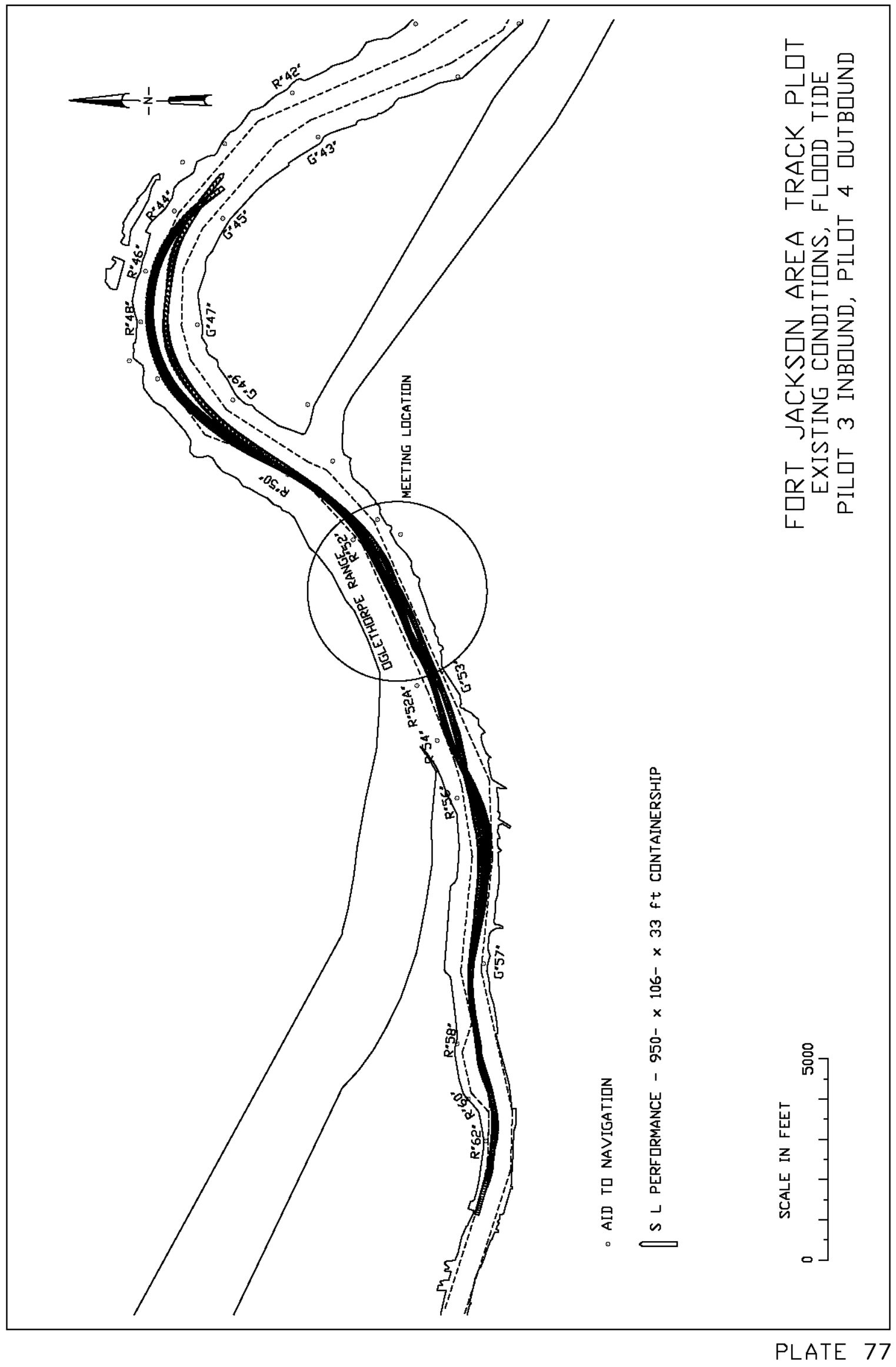




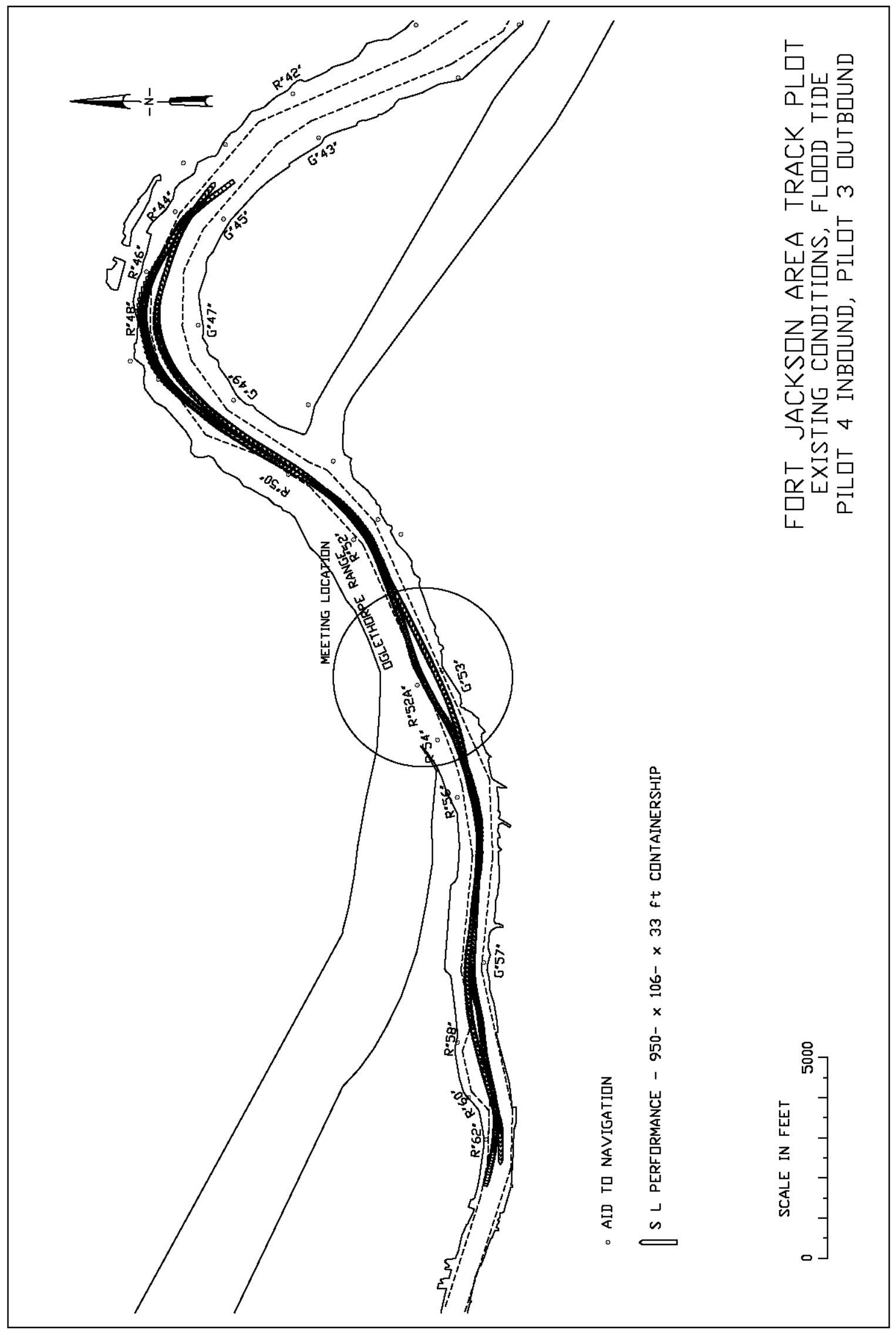

PLATE 78 


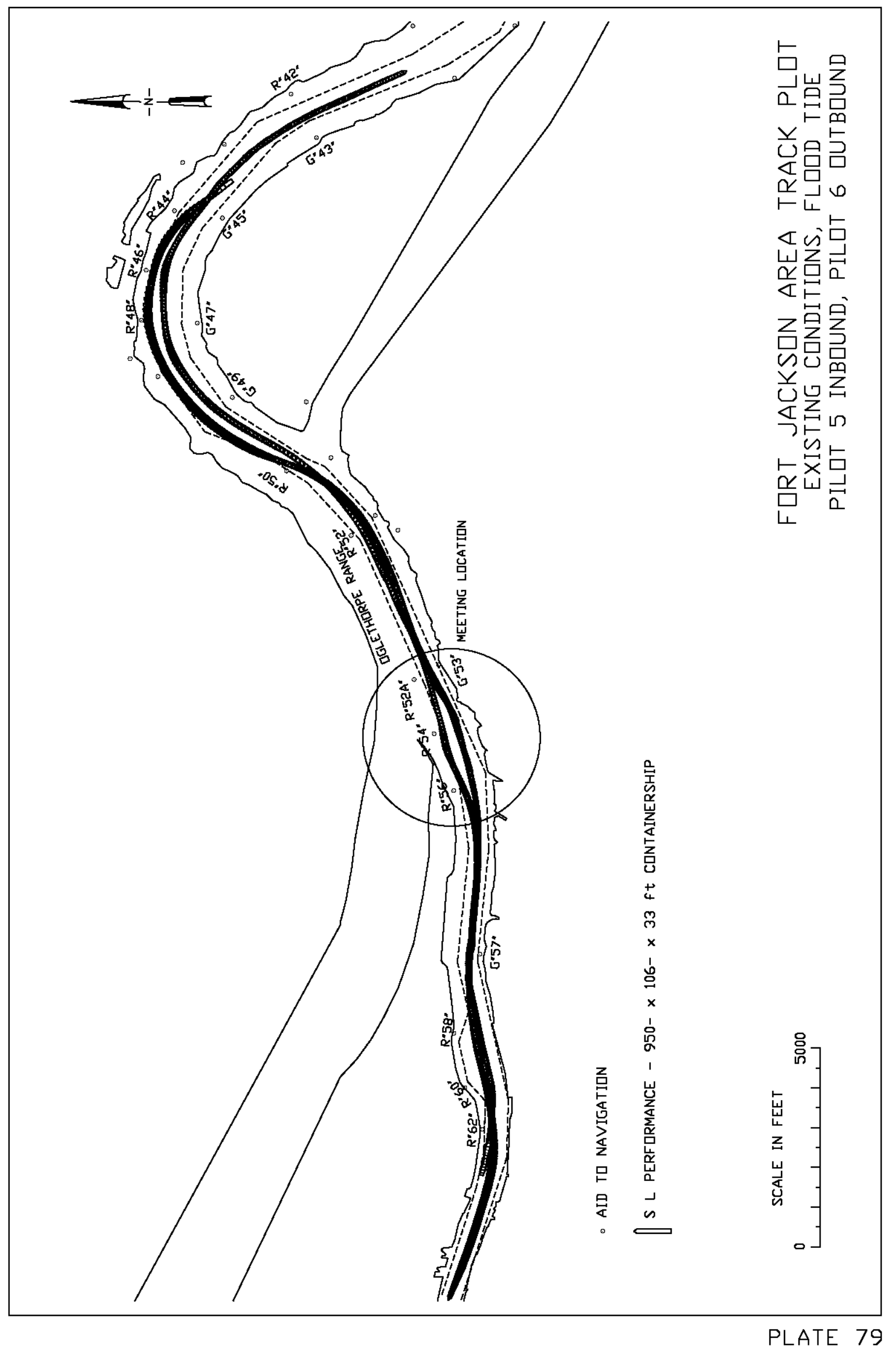




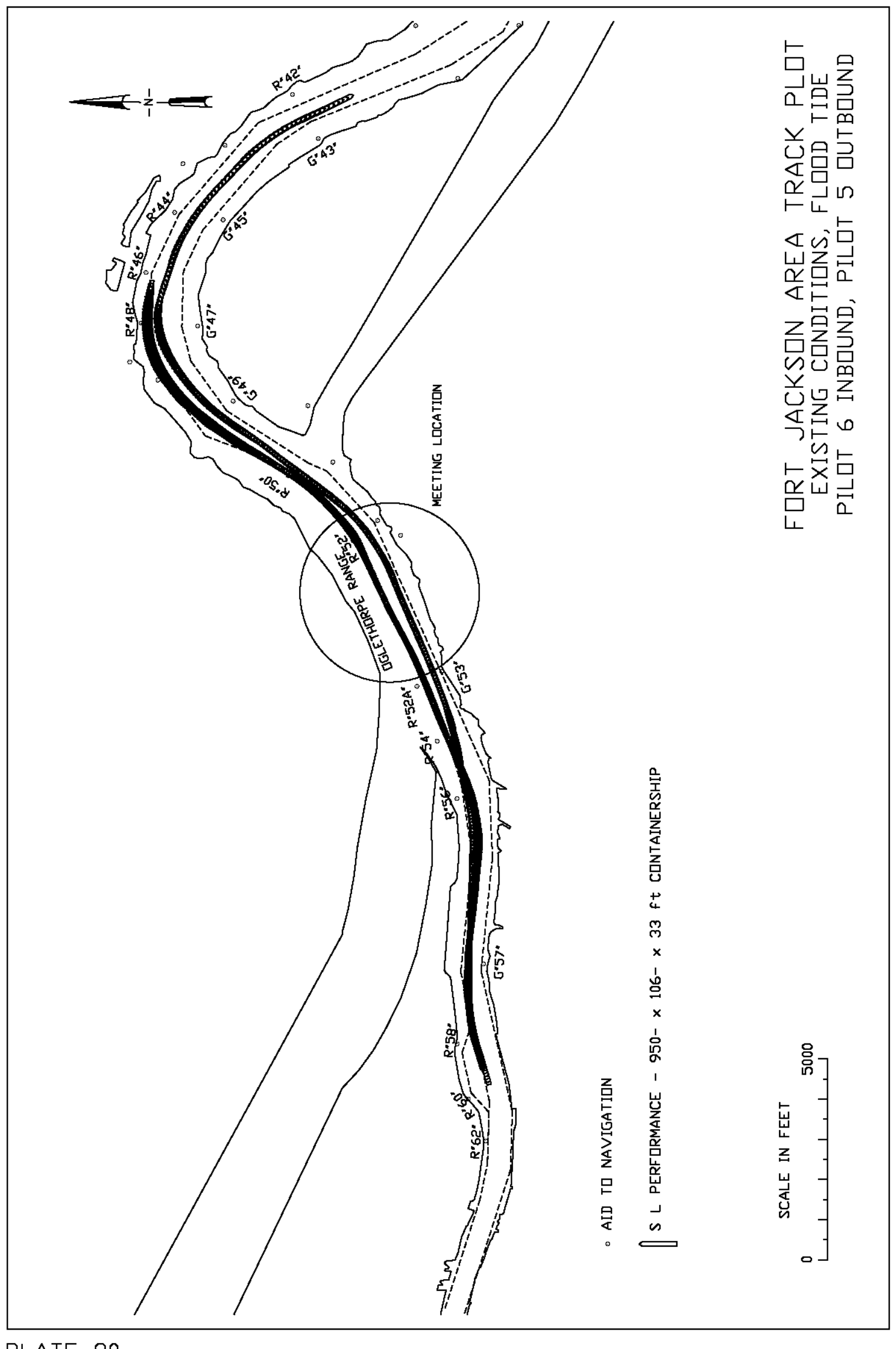

PLATE 80 


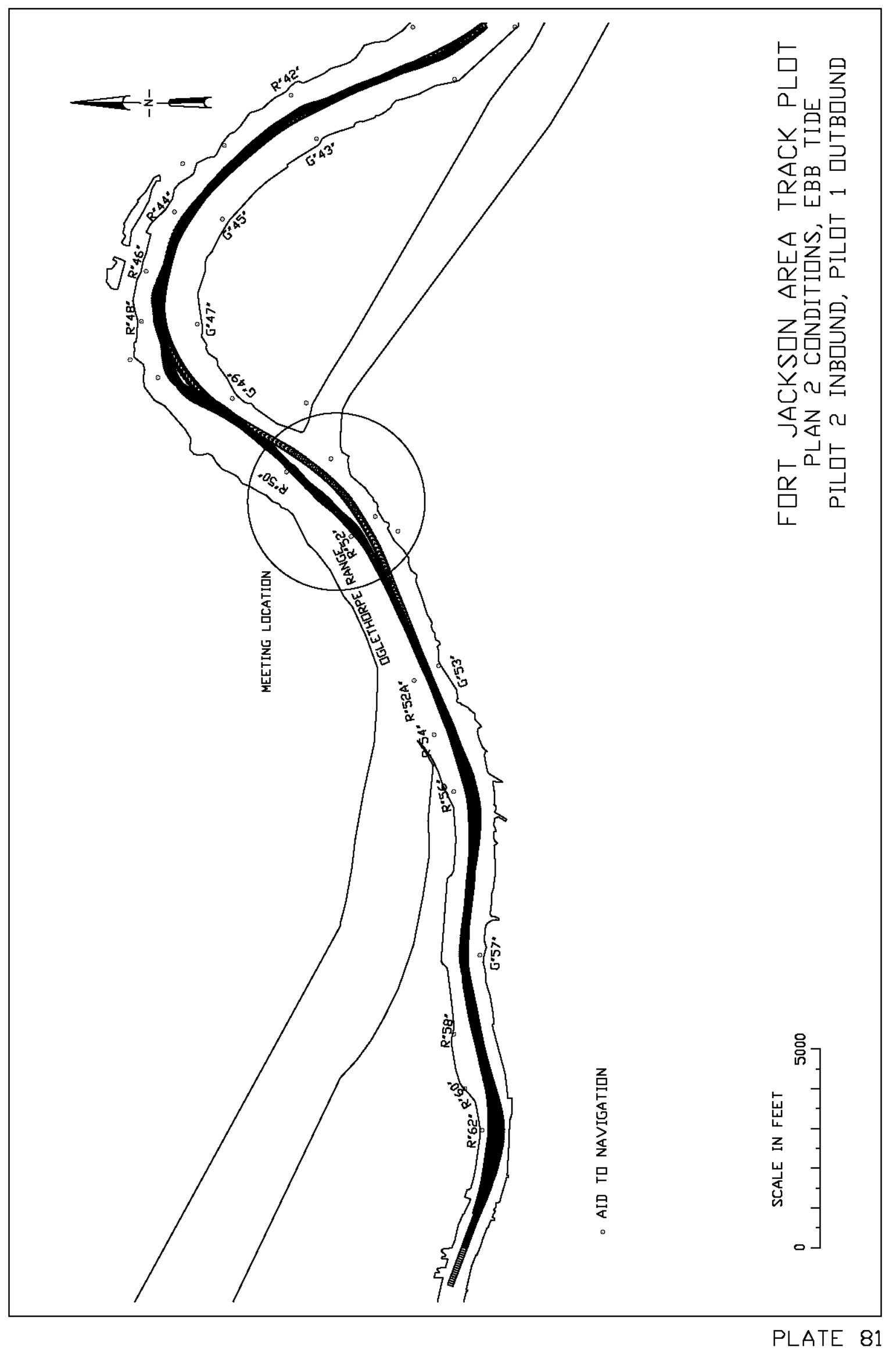




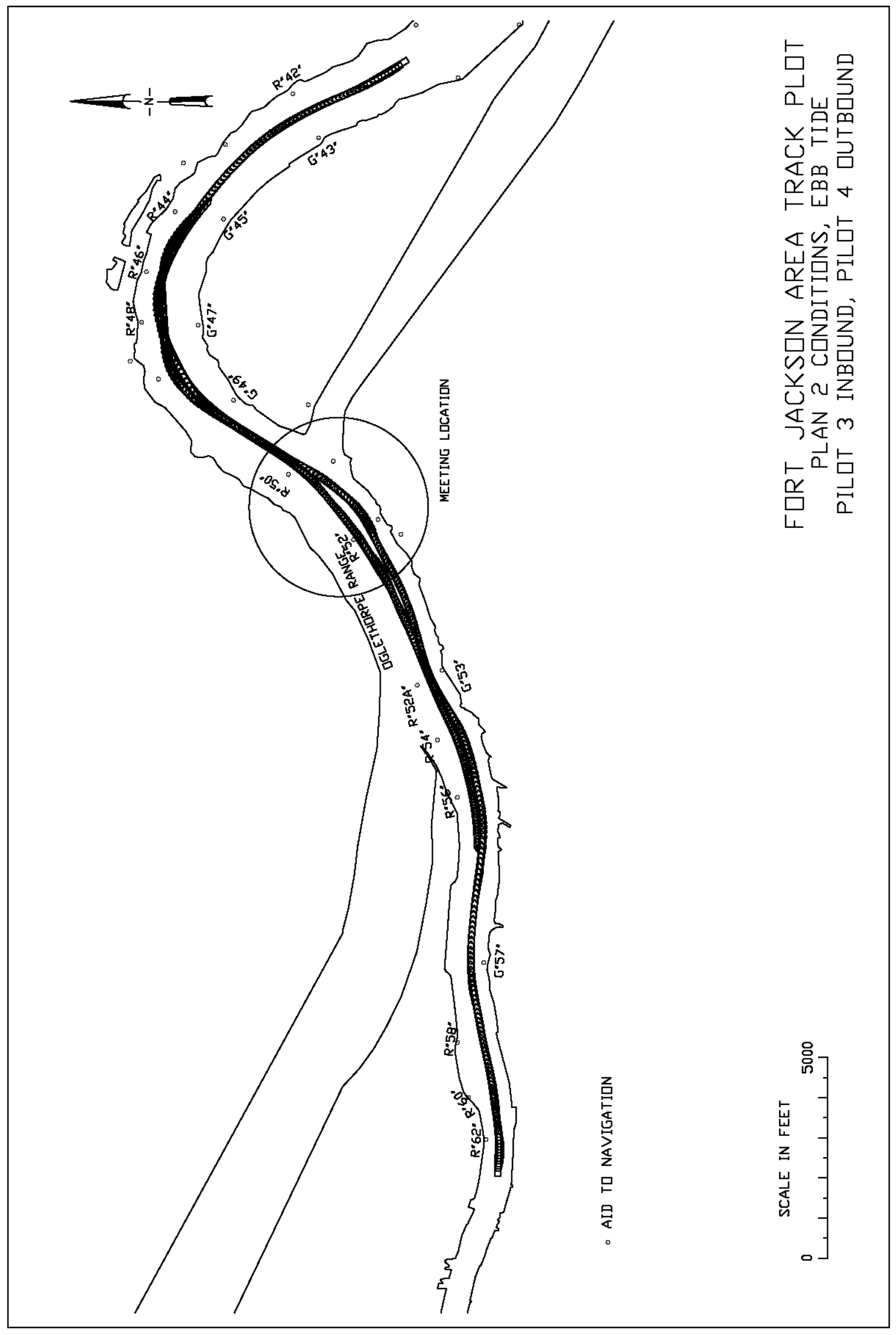

PLATE 82 


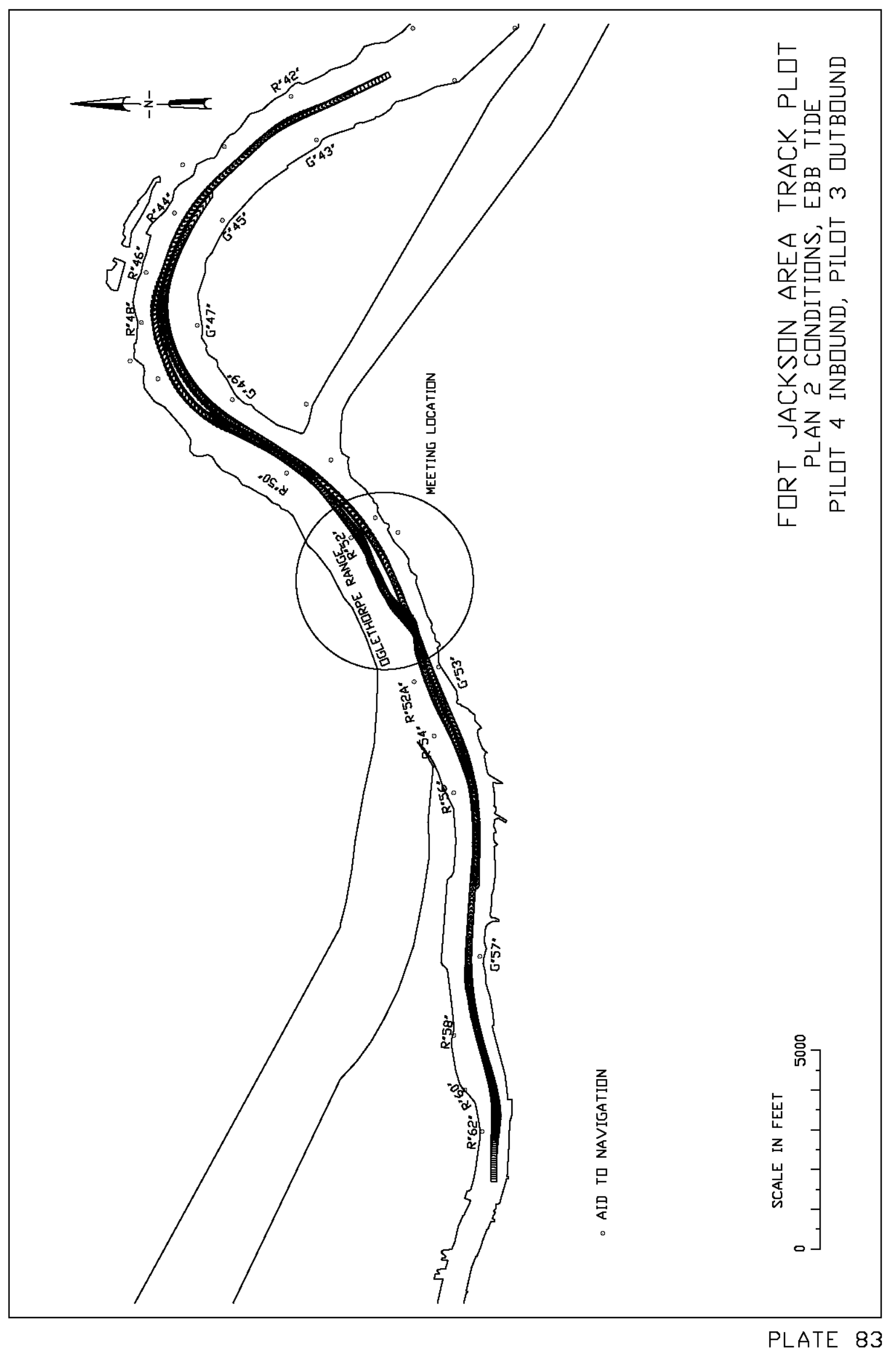




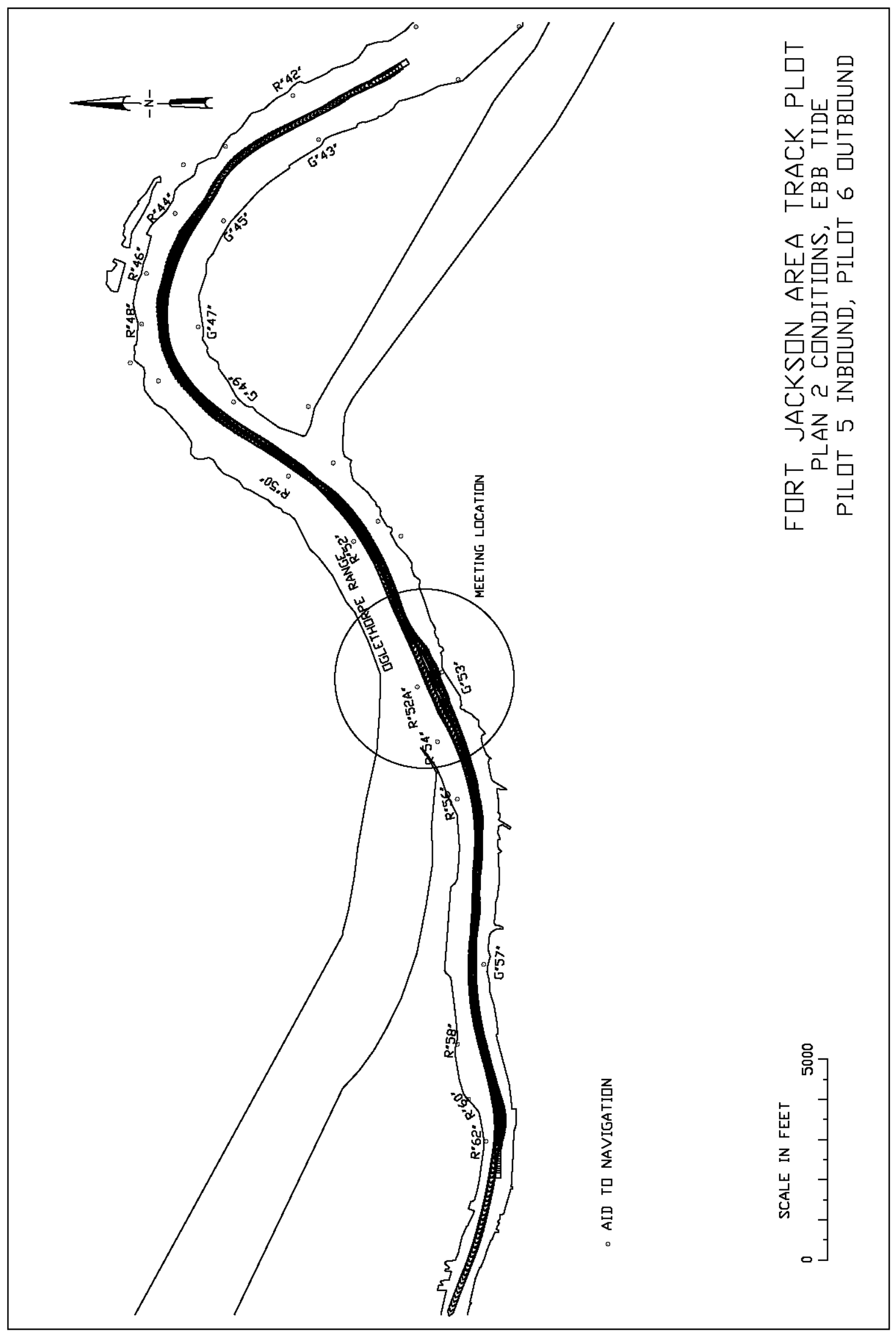

PLATE 84 


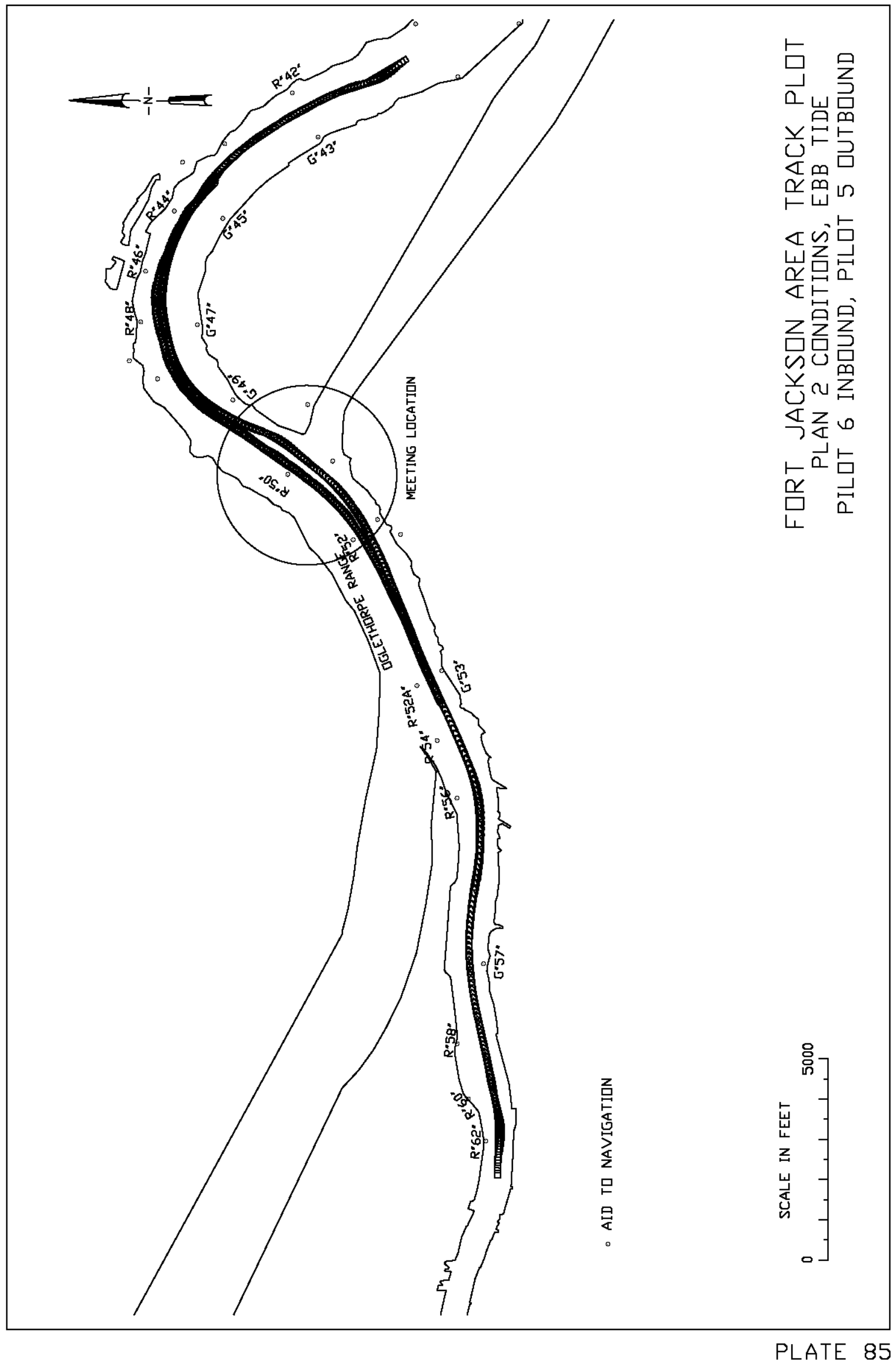




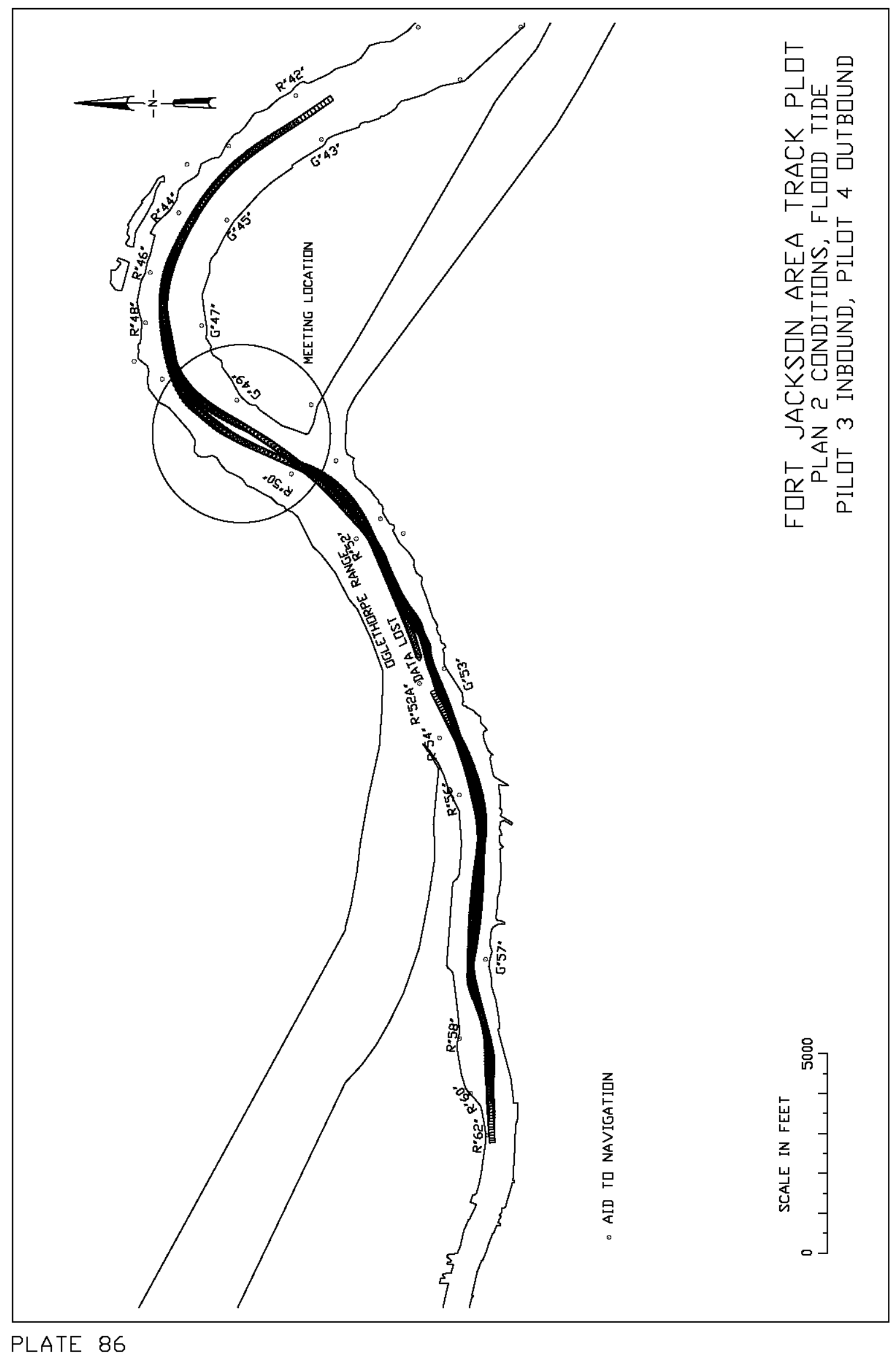




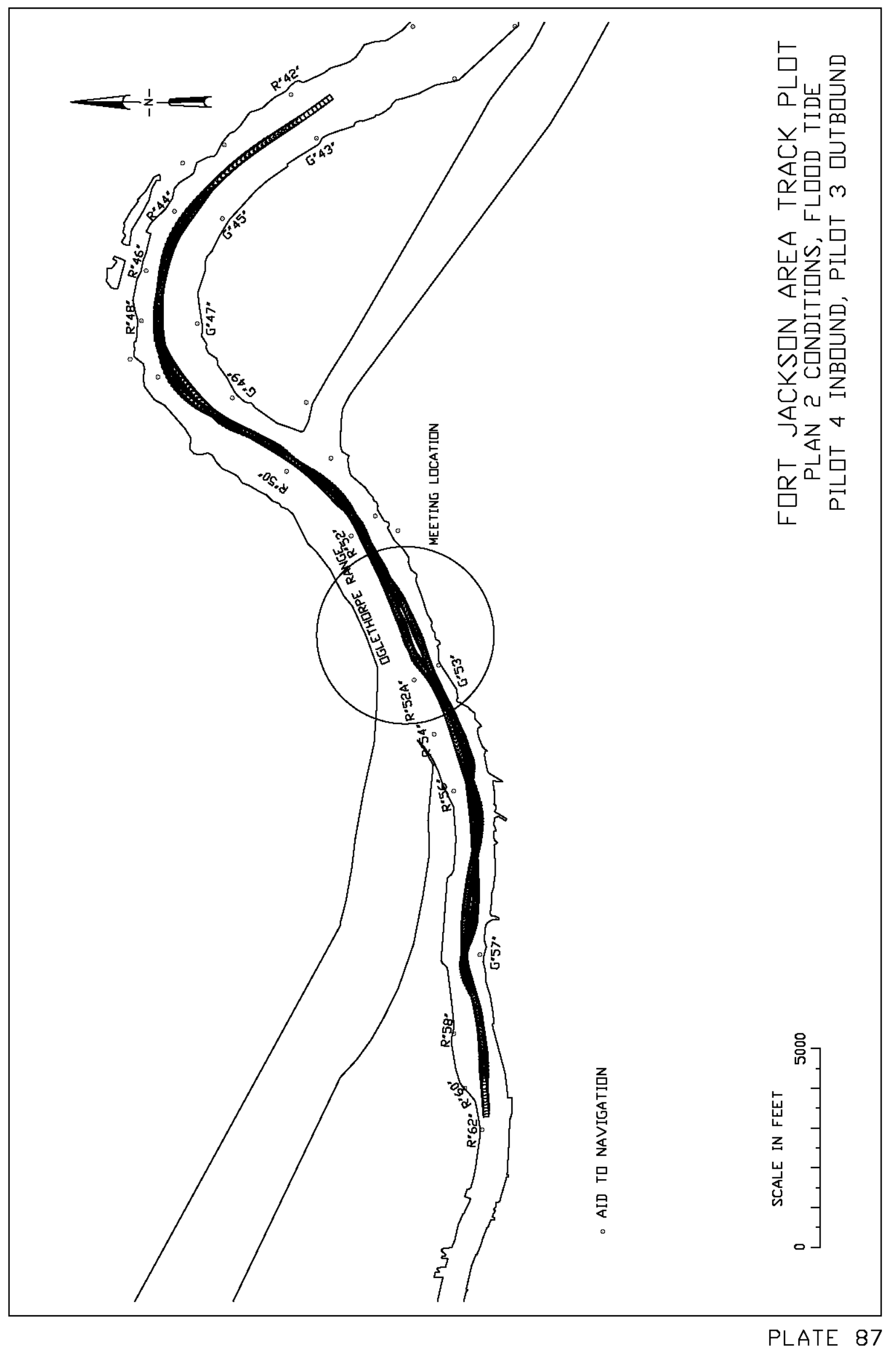




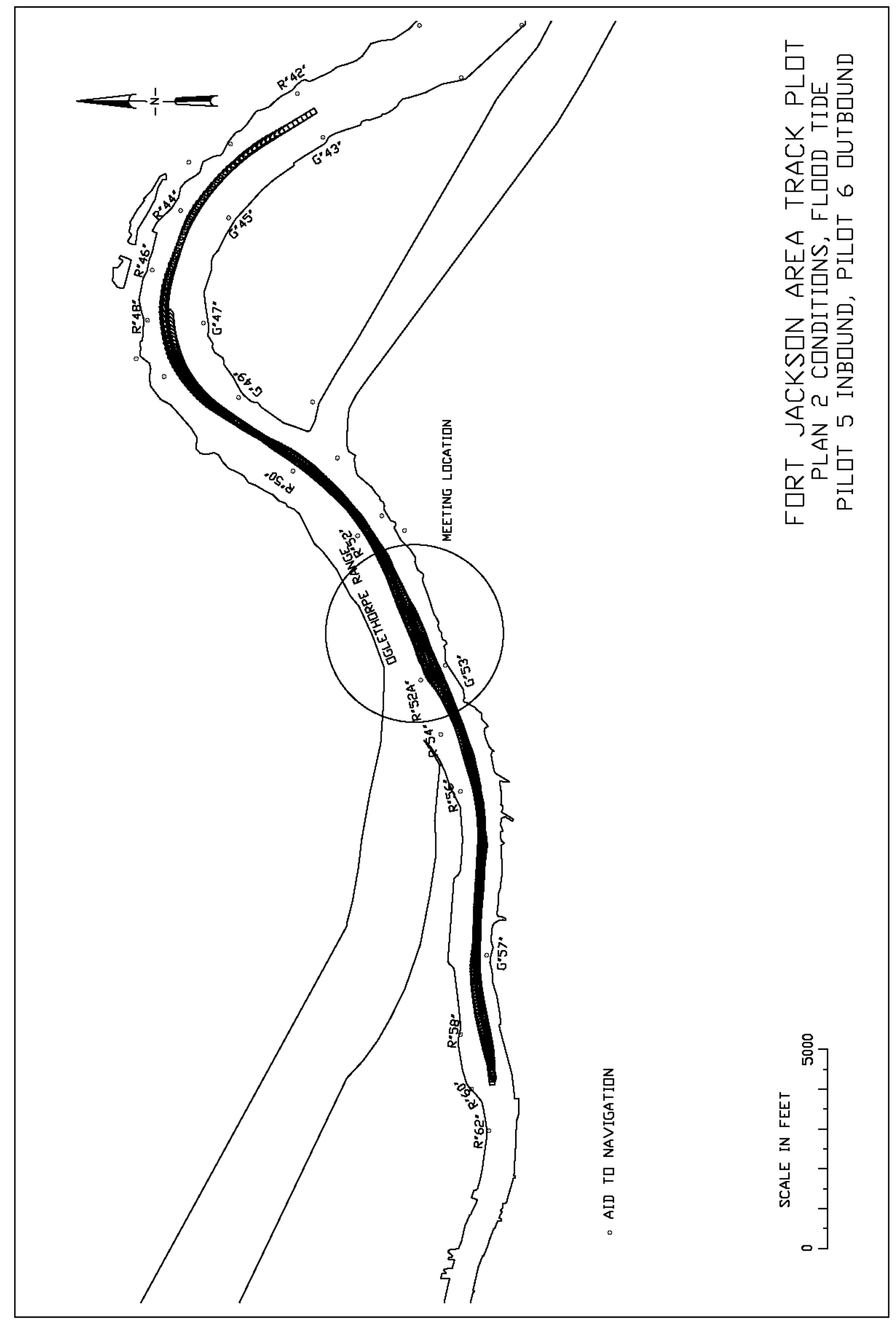

PLATE 88 


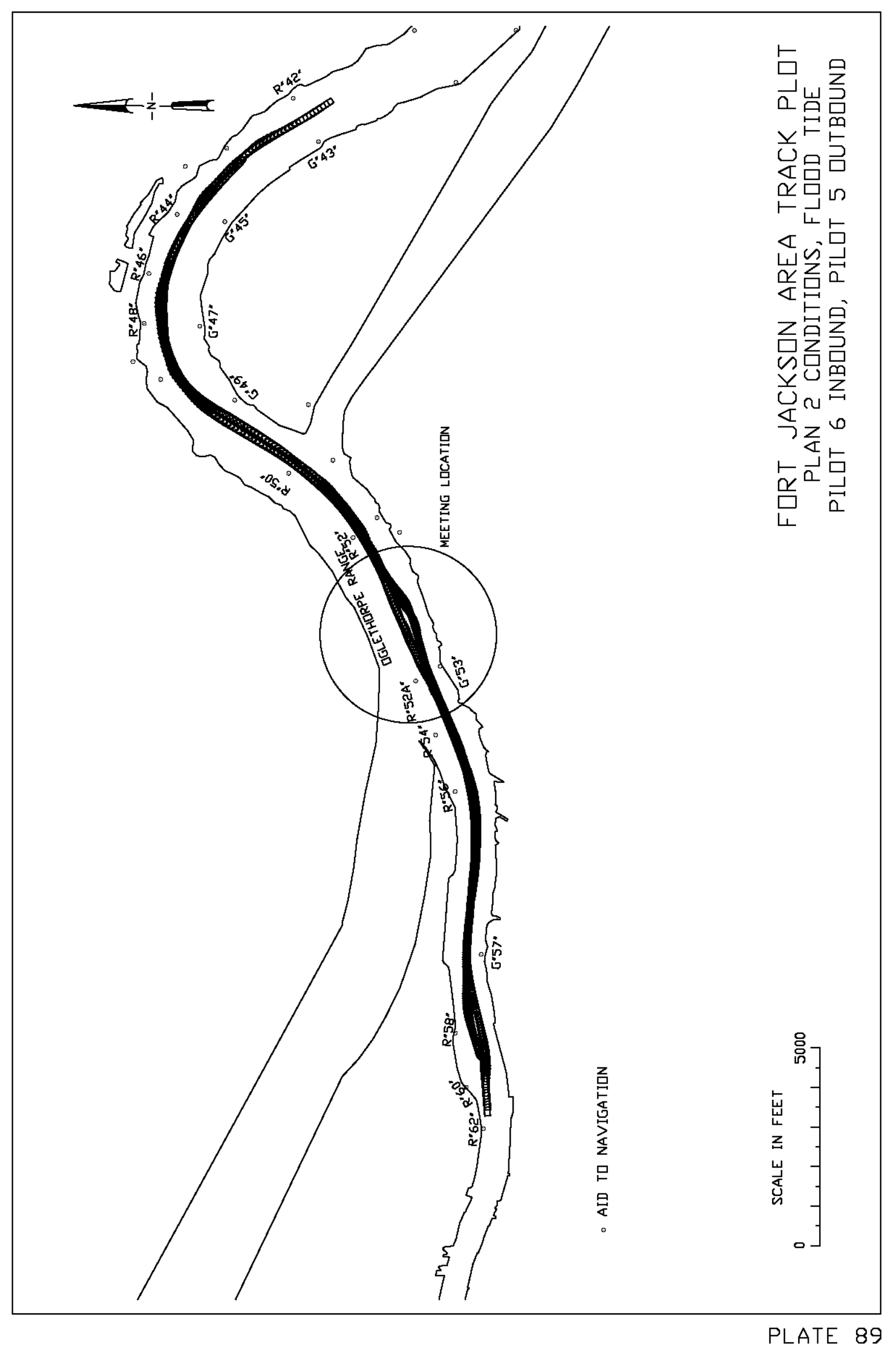




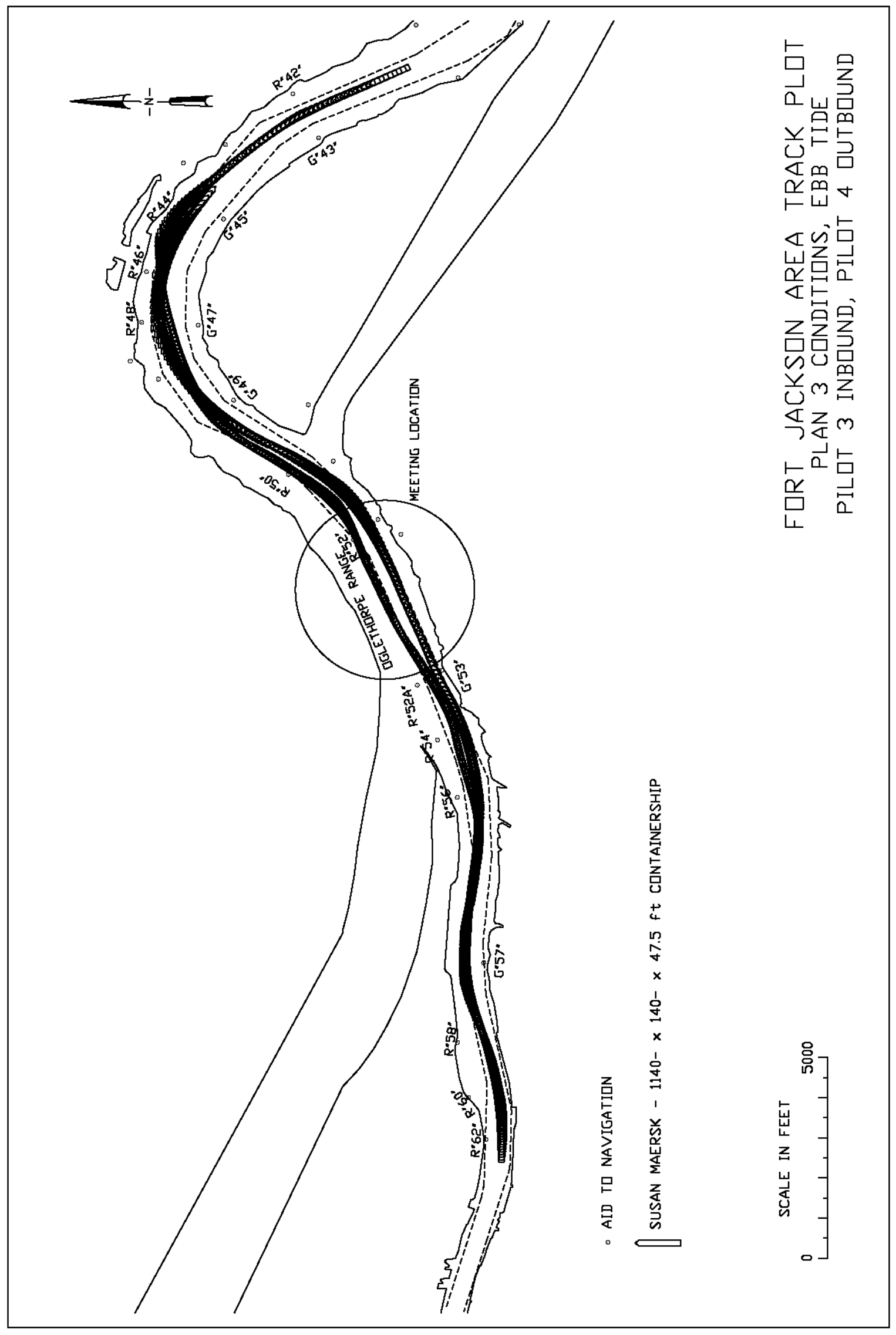

PLATE 90 


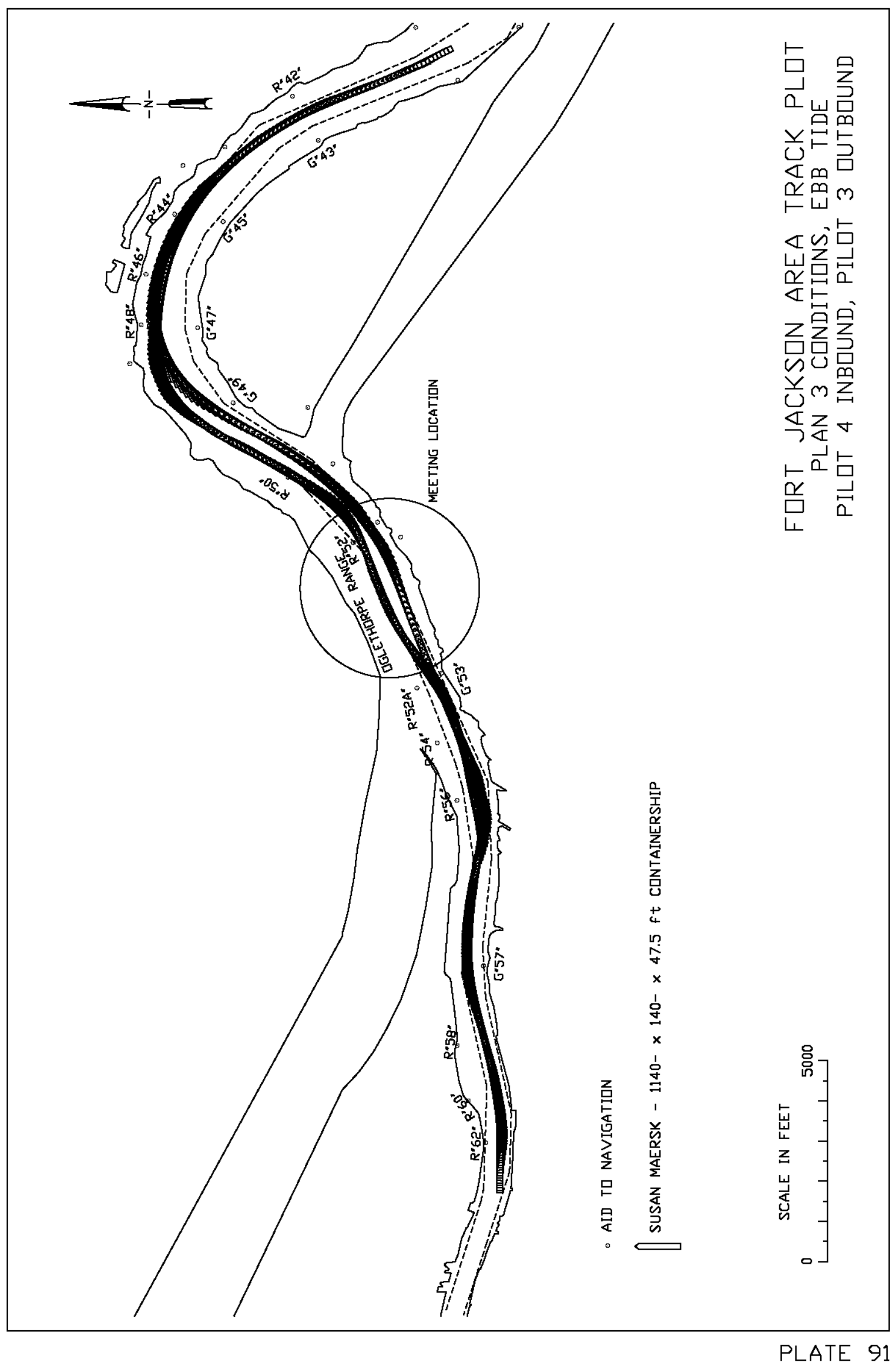




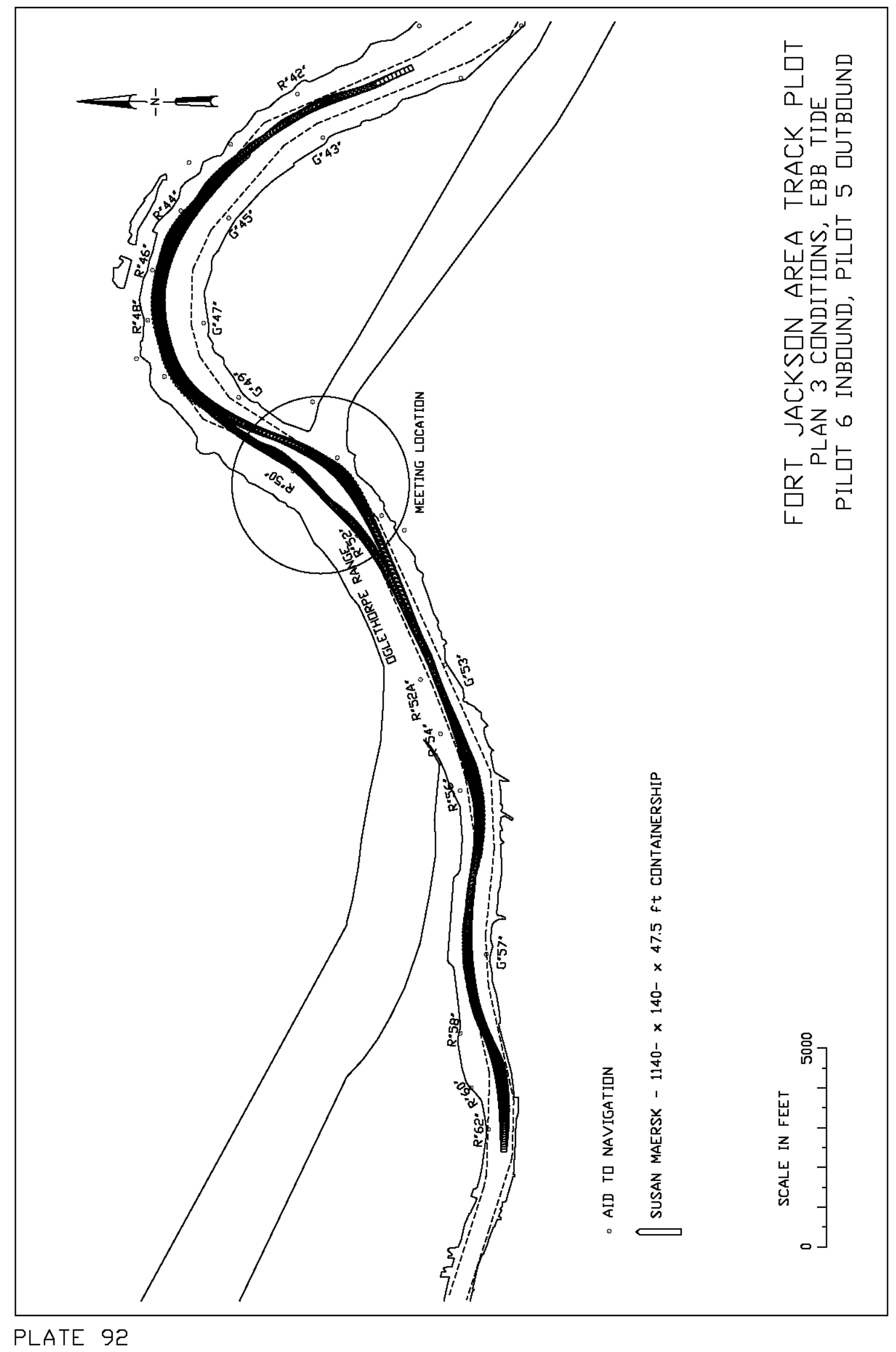




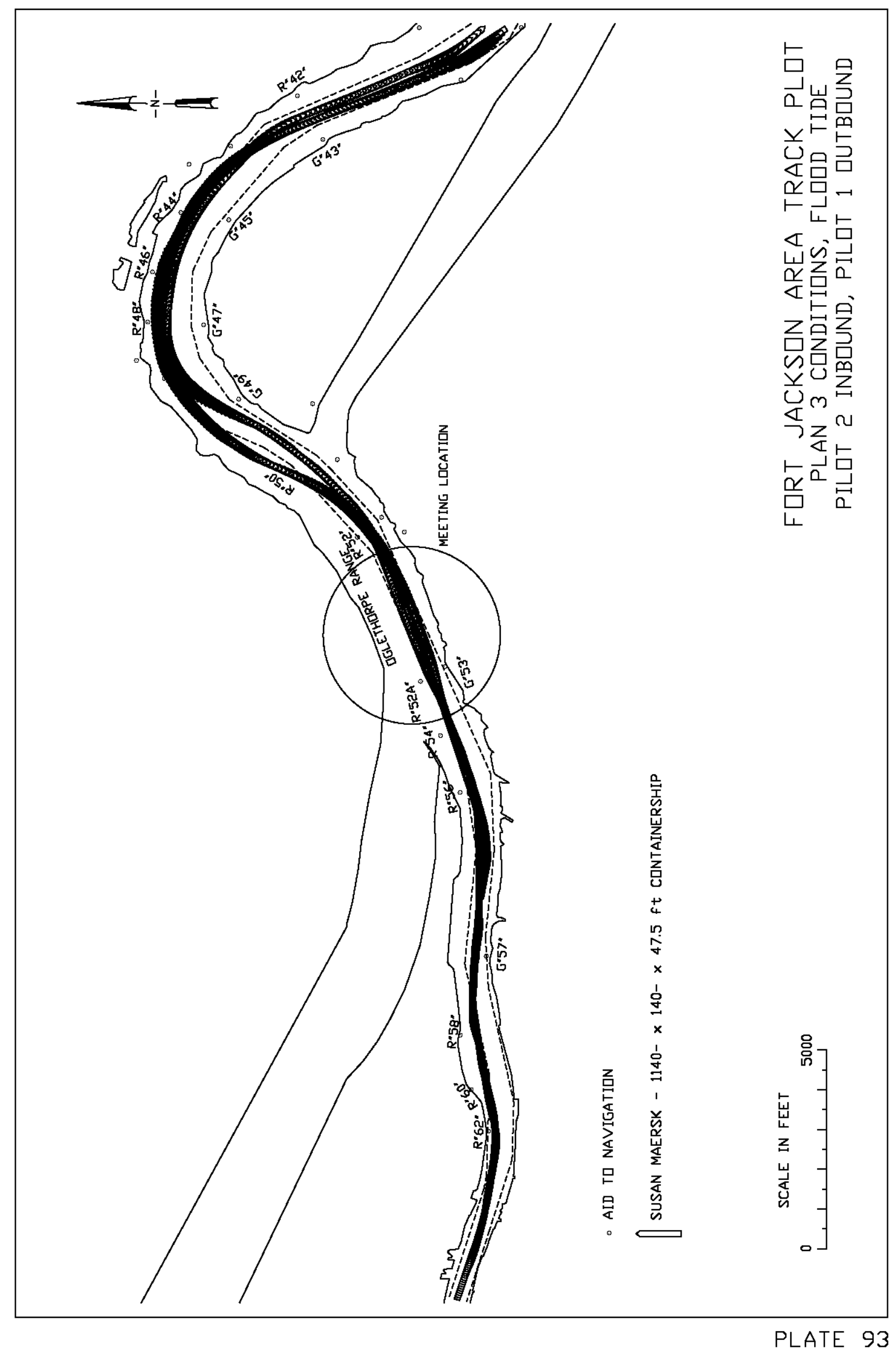




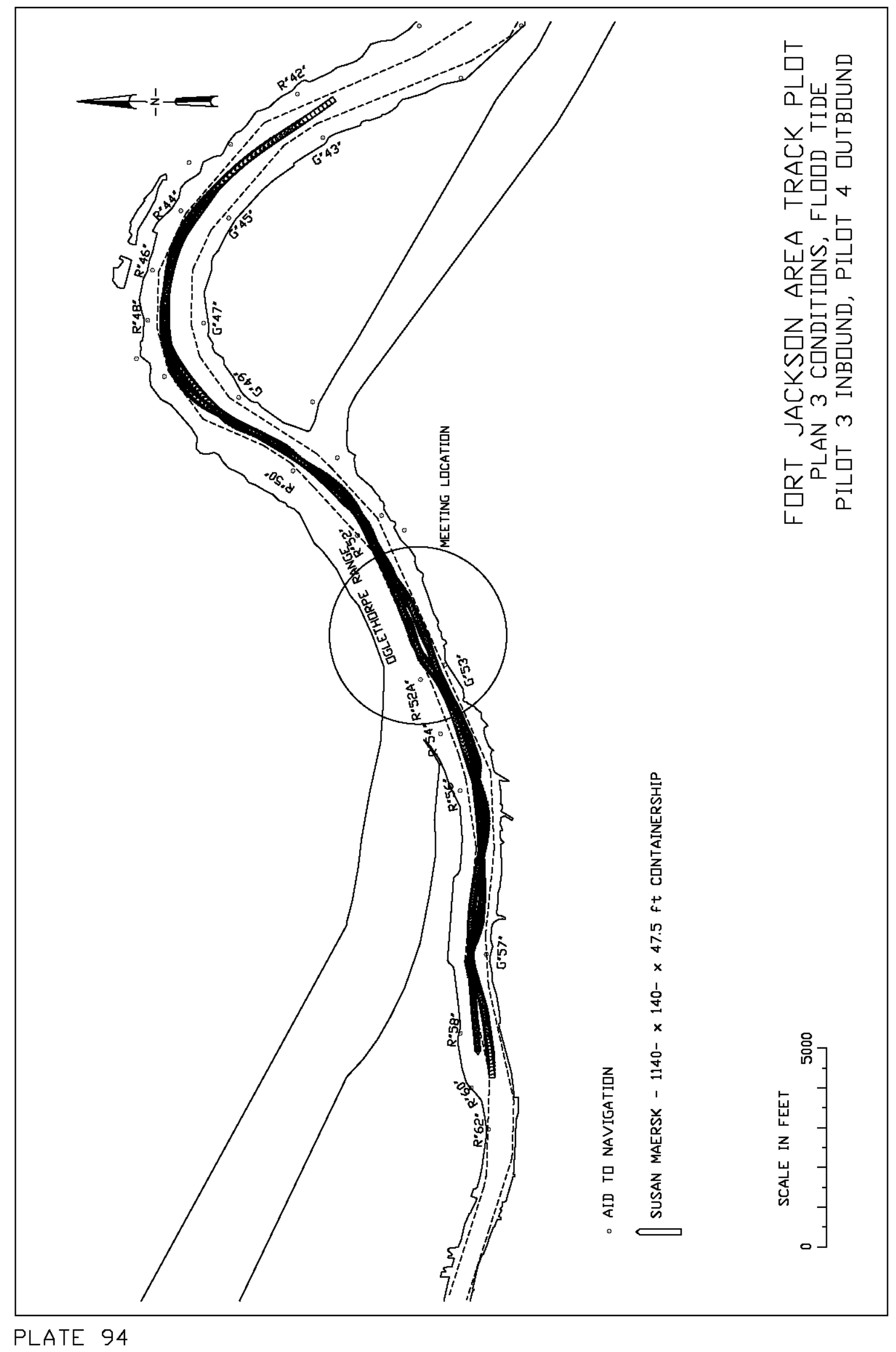




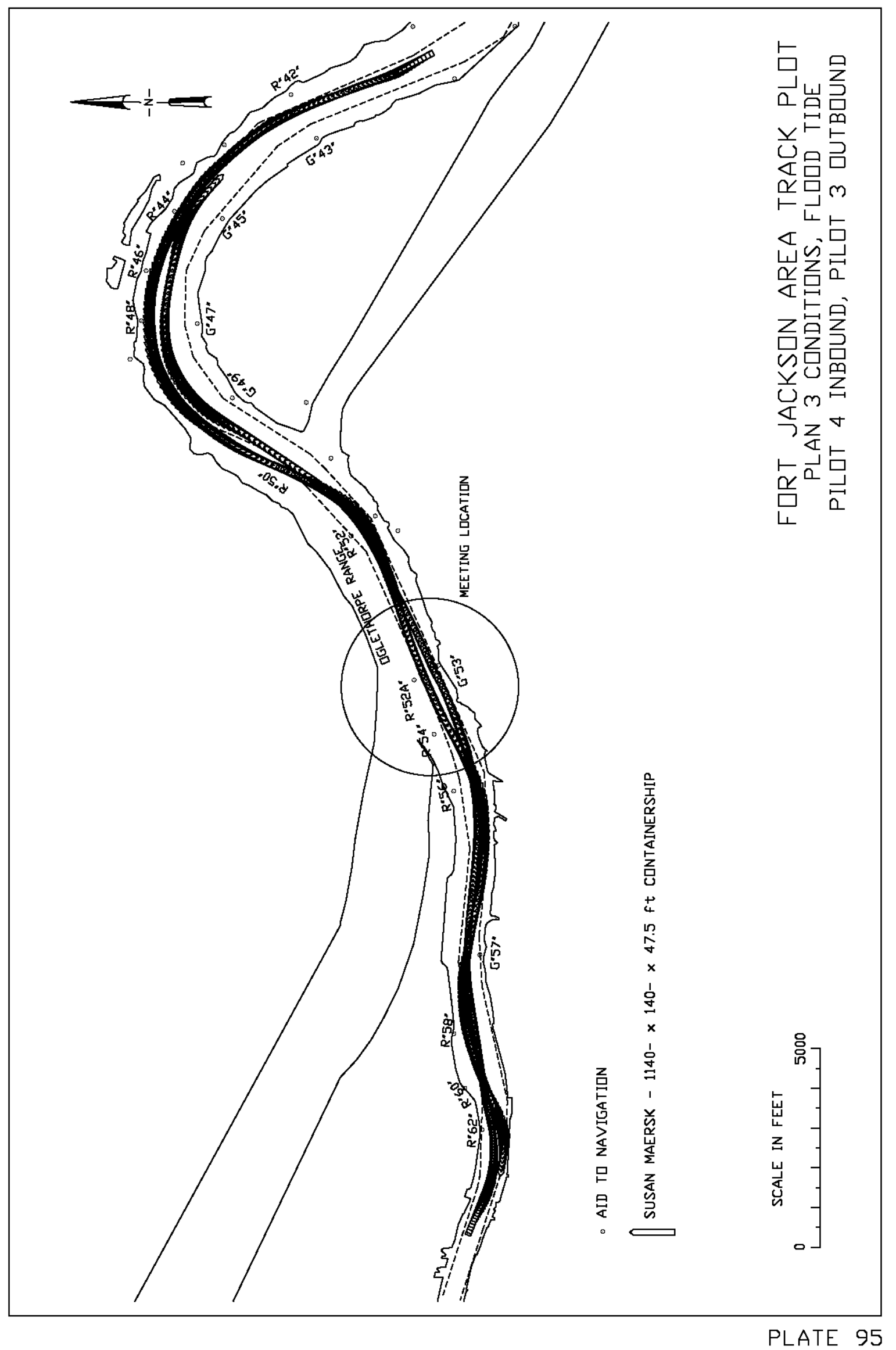




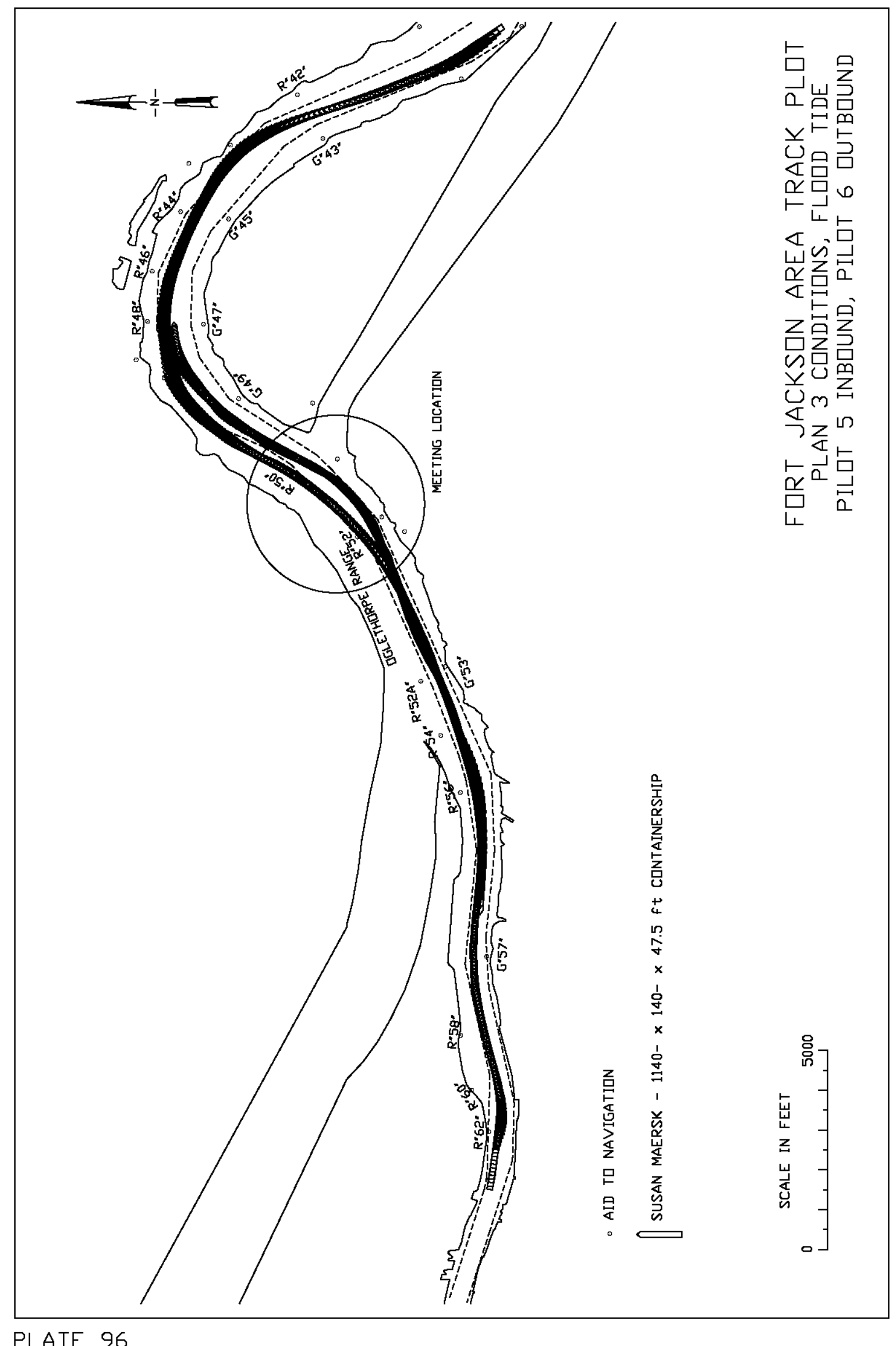

PLATE 96 


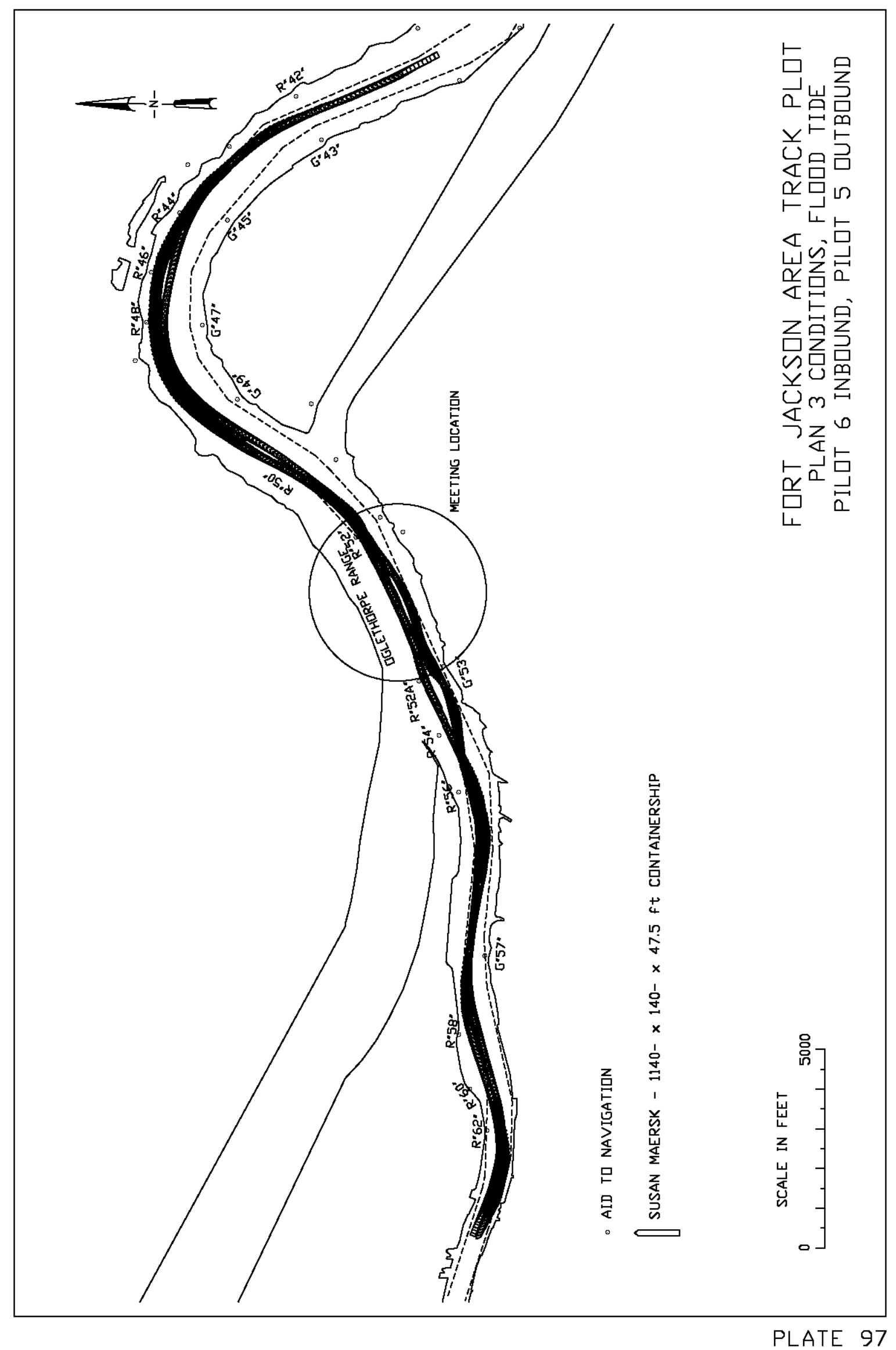




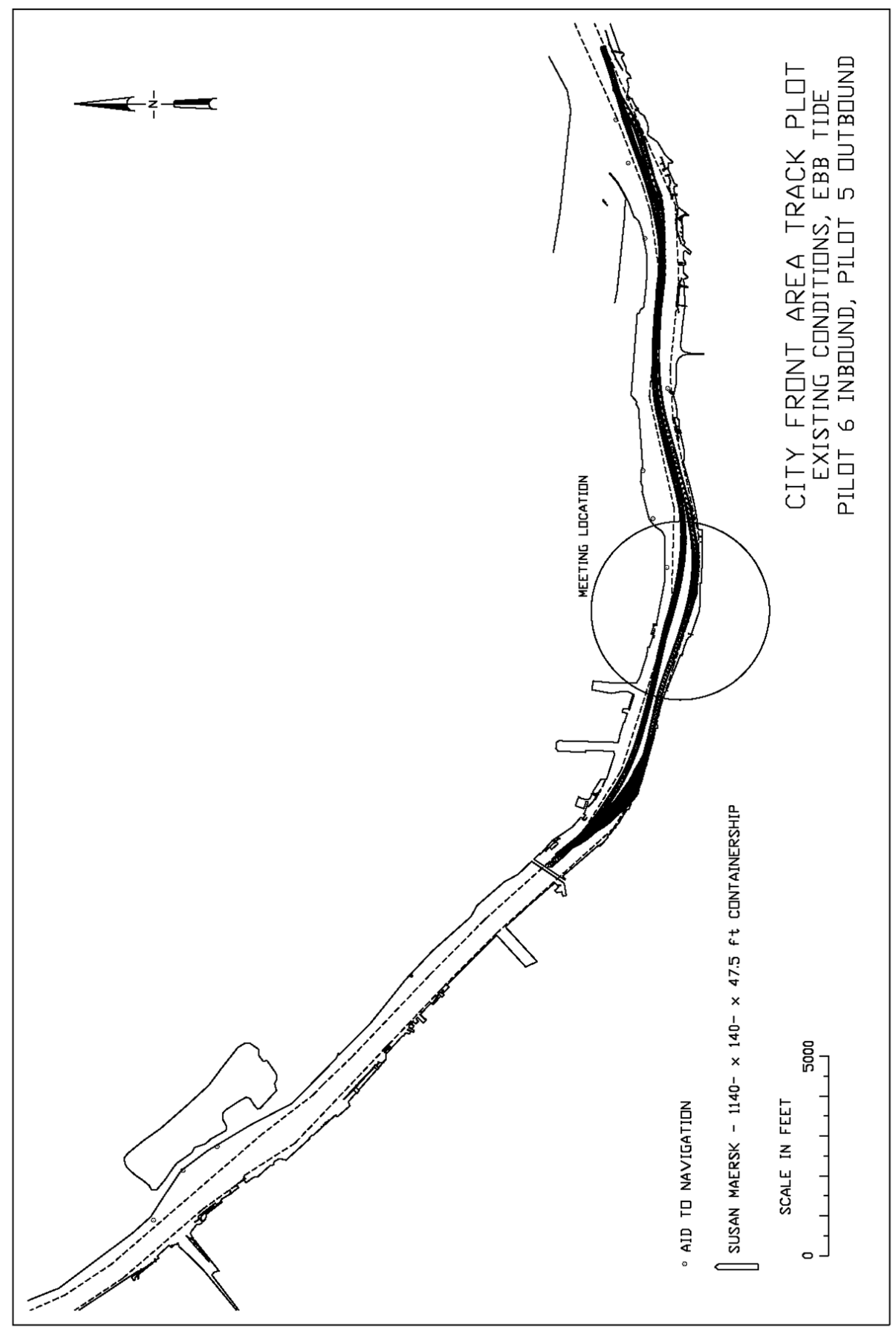

PLATE 98 


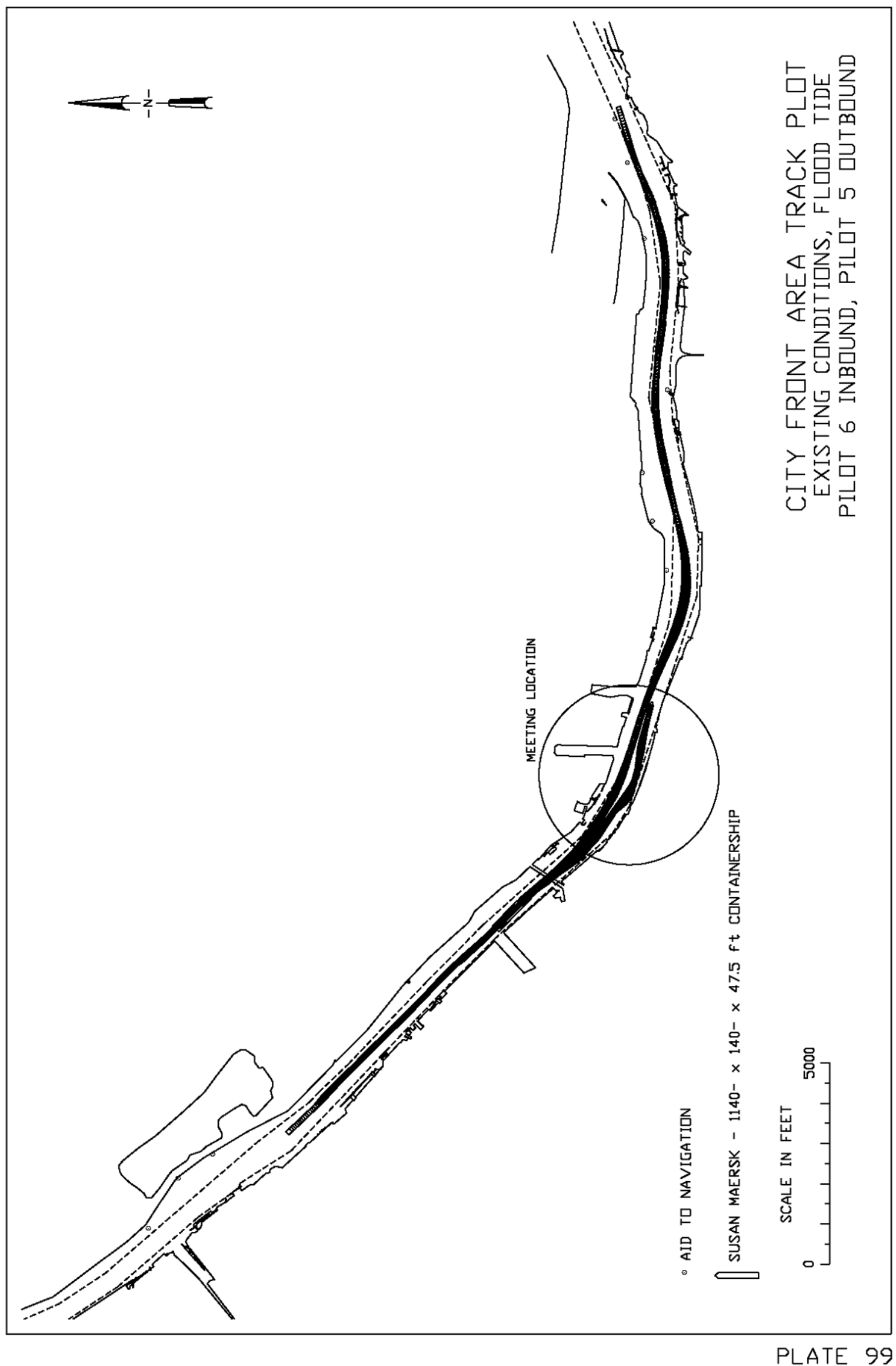




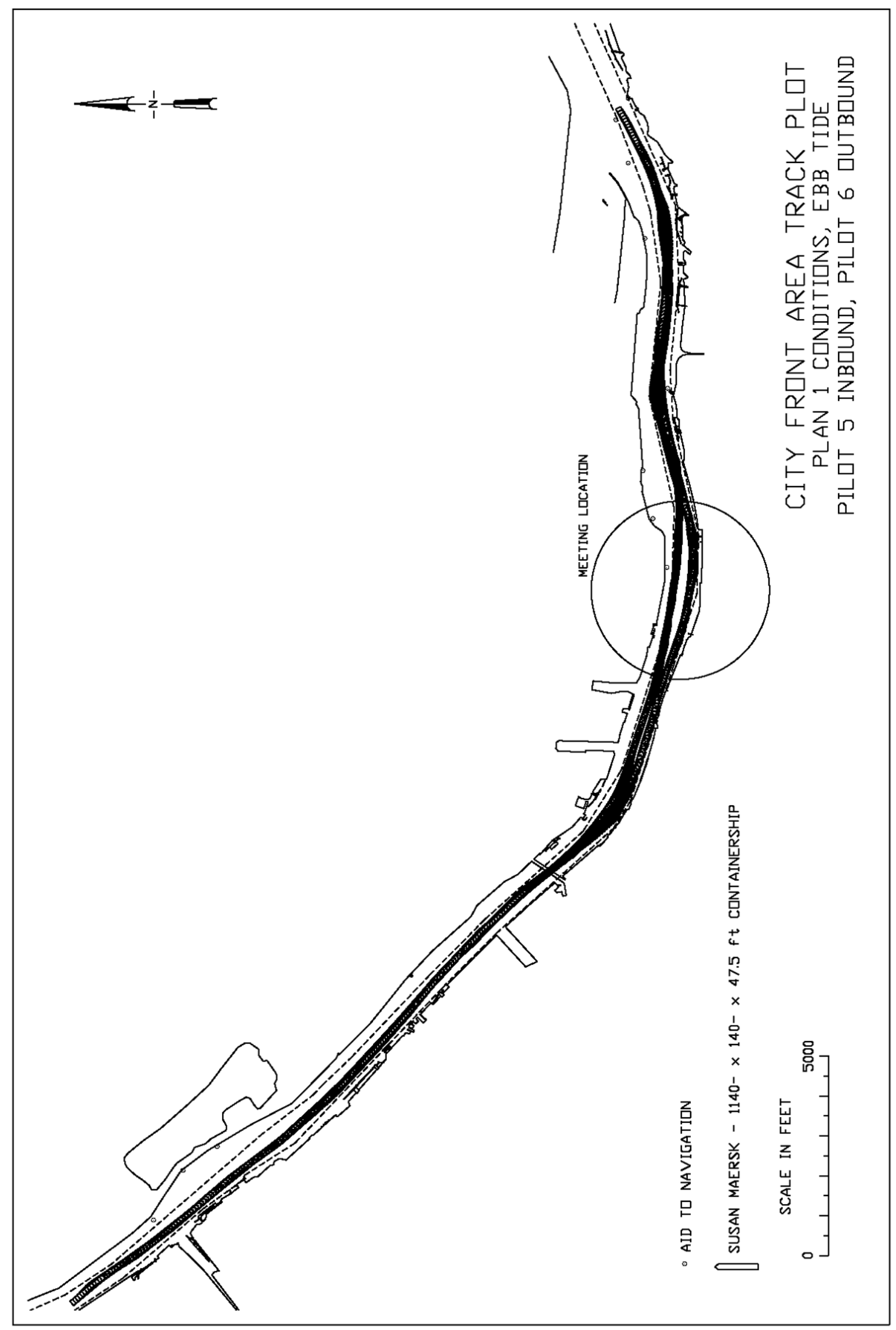

PLATE 100 


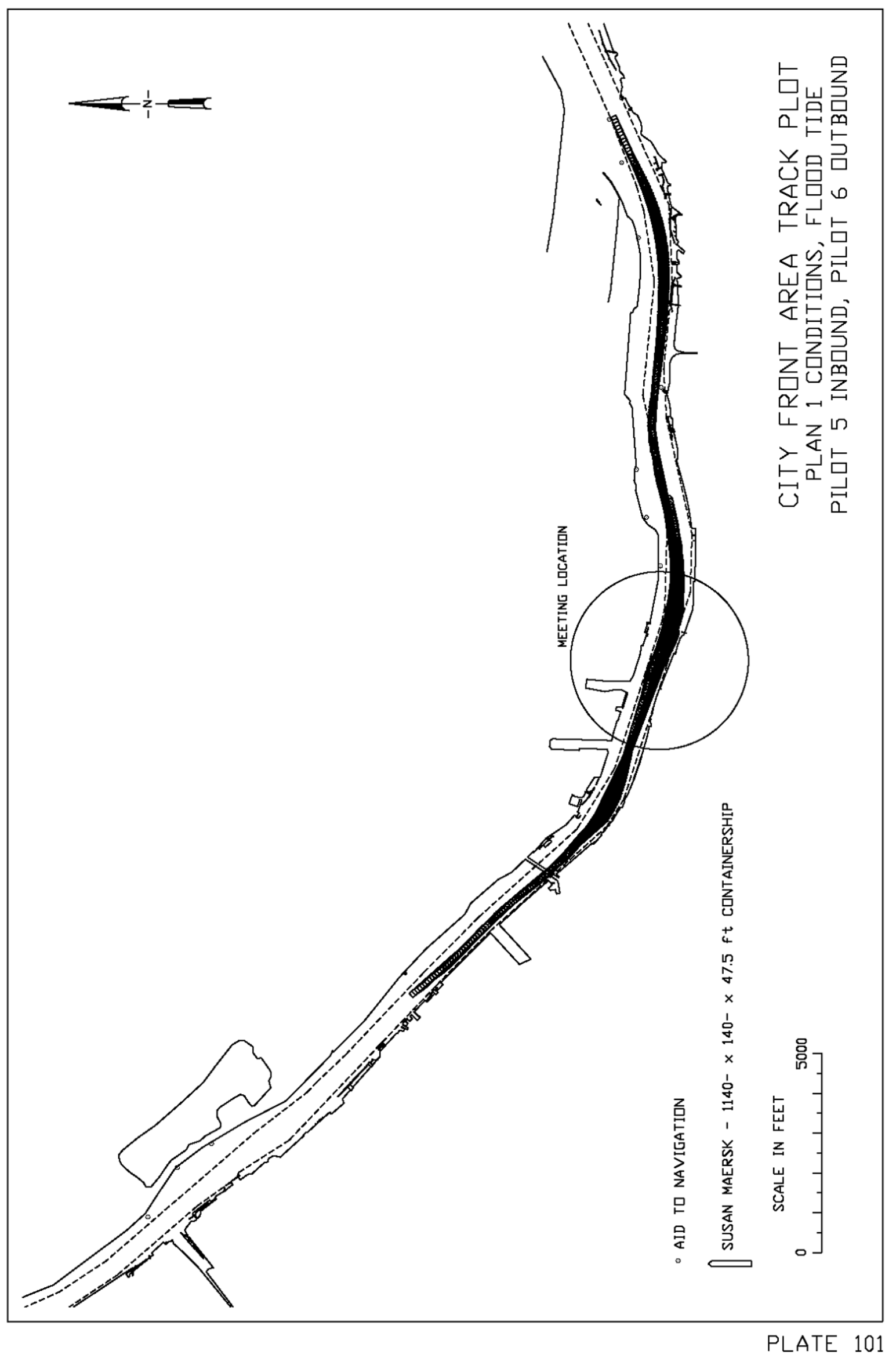




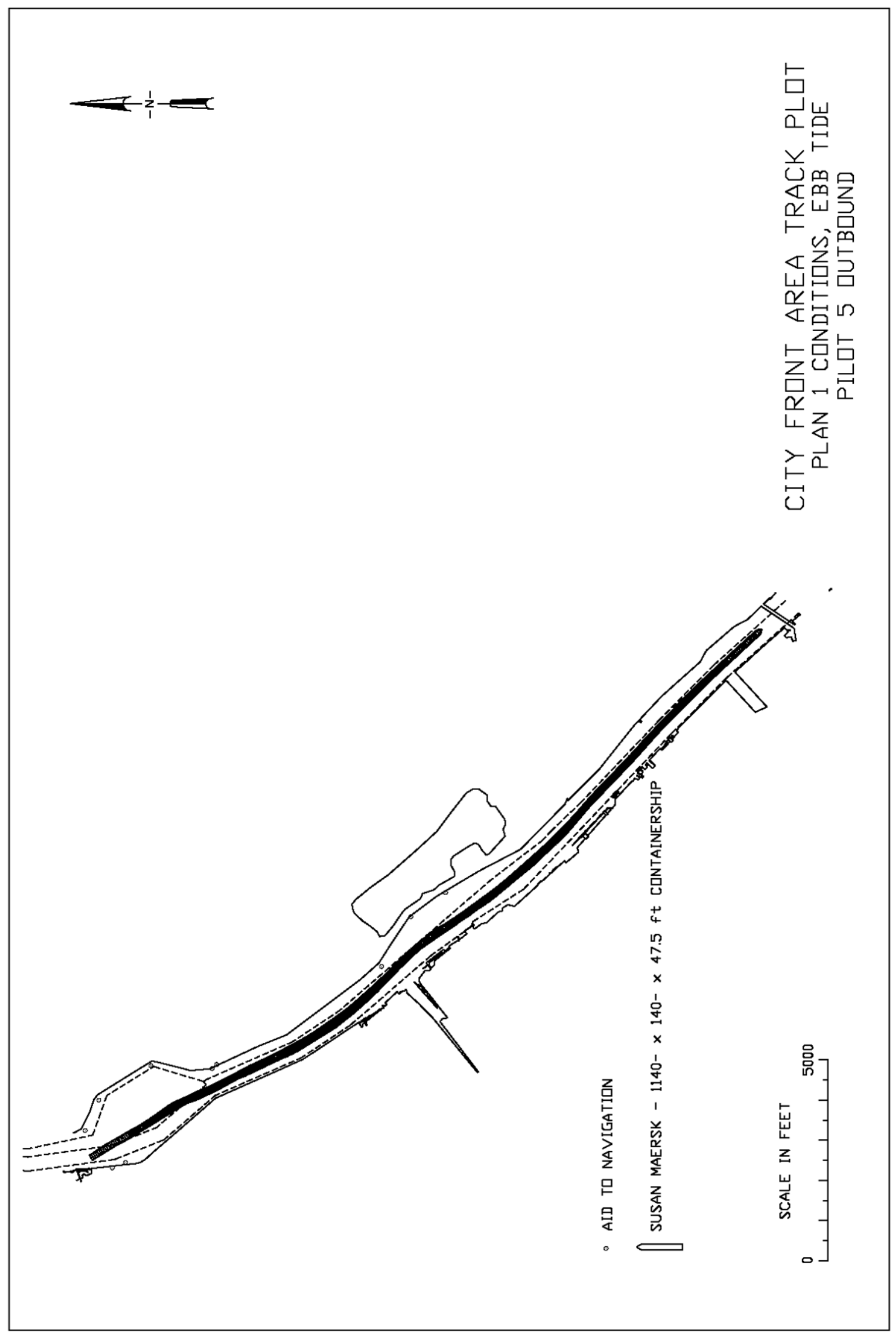

PLATE 102 


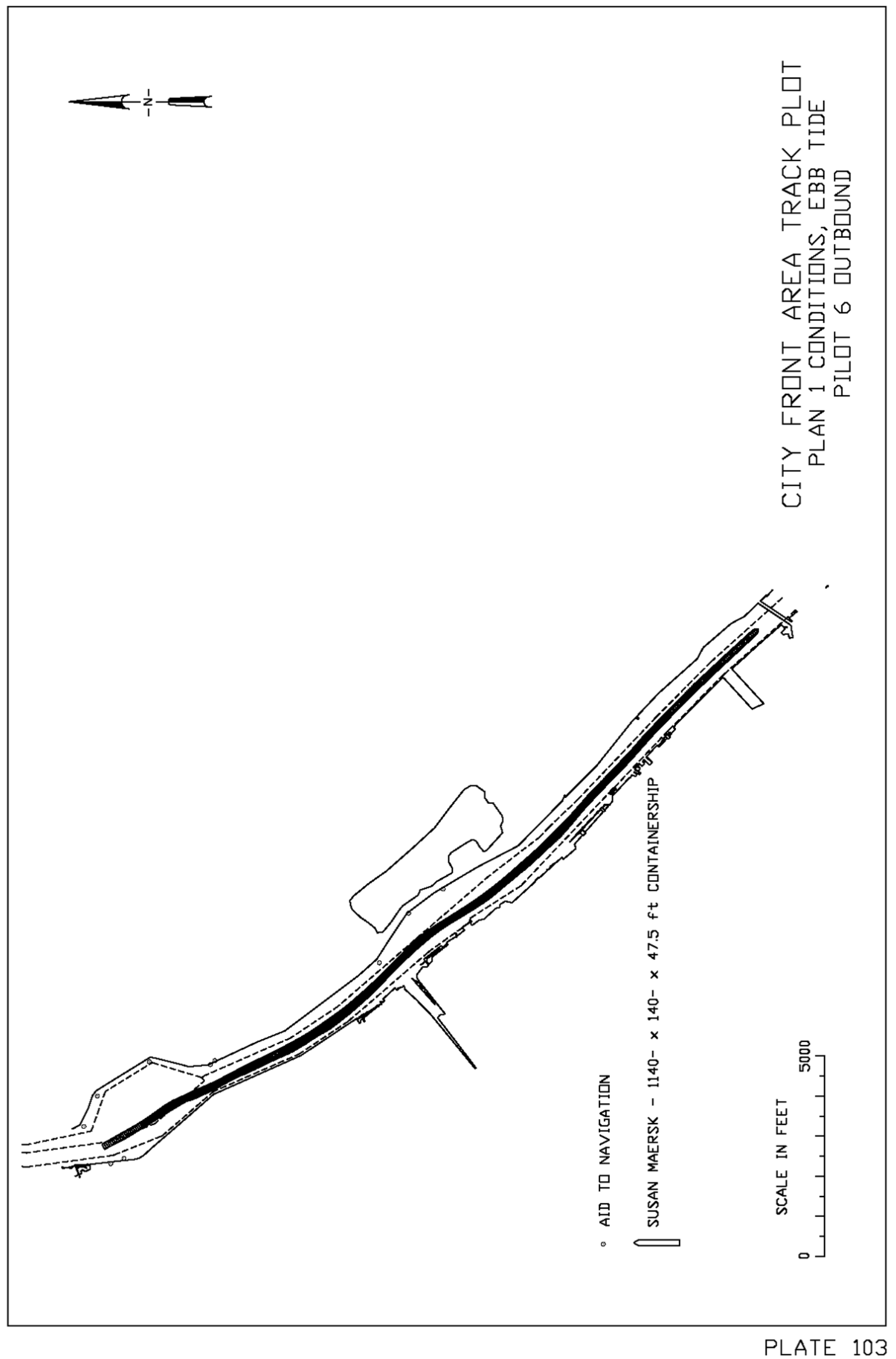




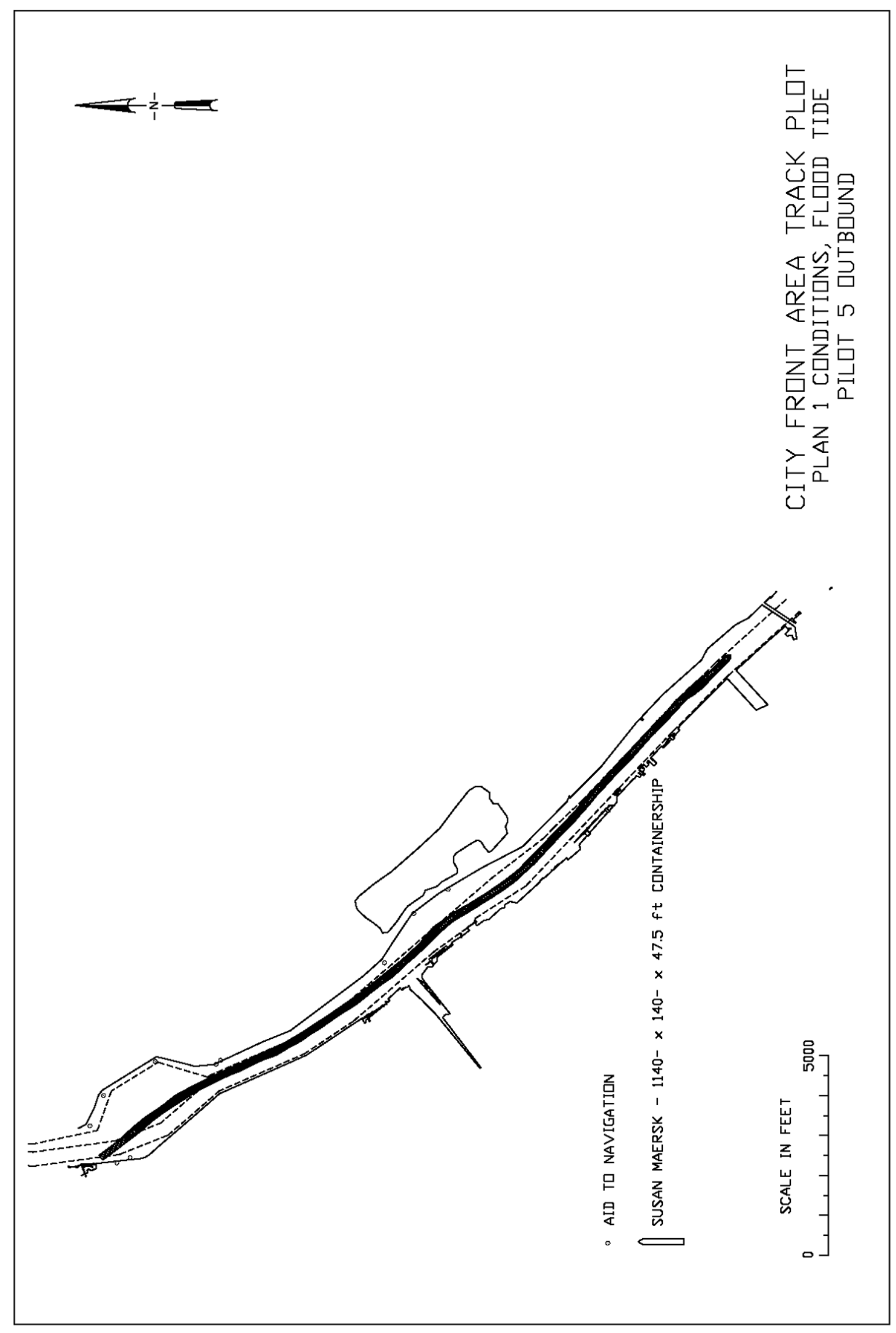

PLATE 104 


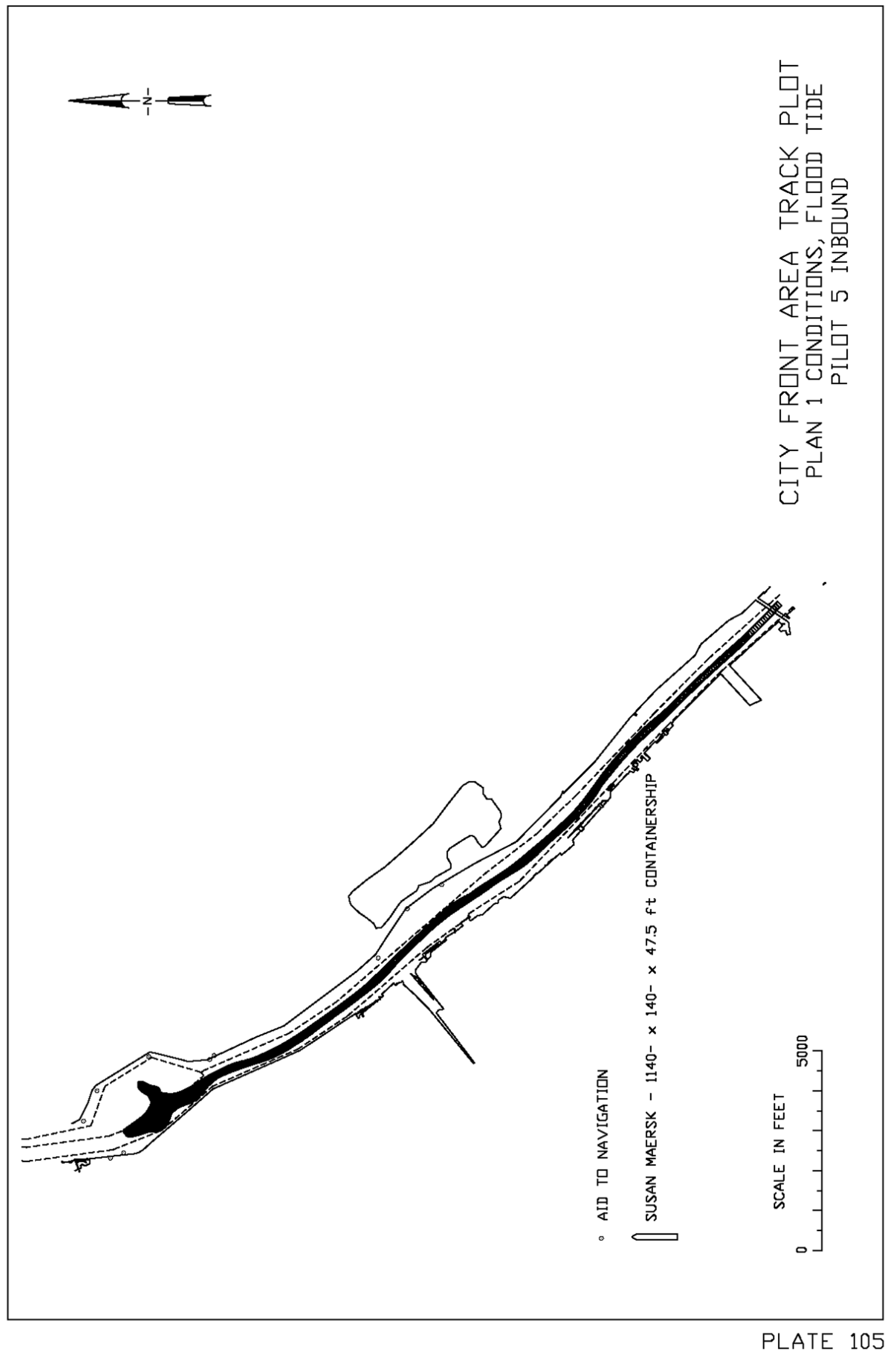




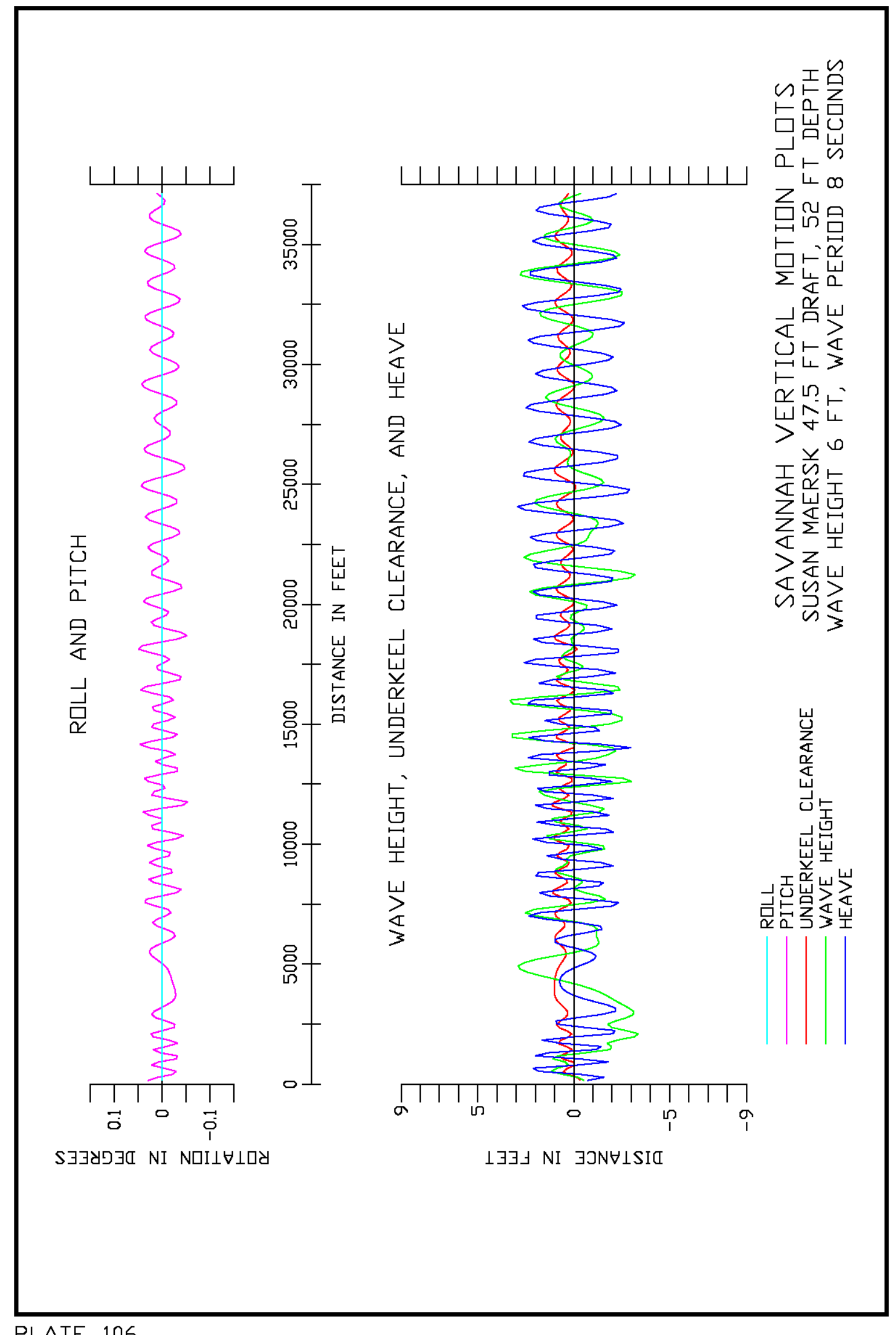

PLATE 106 


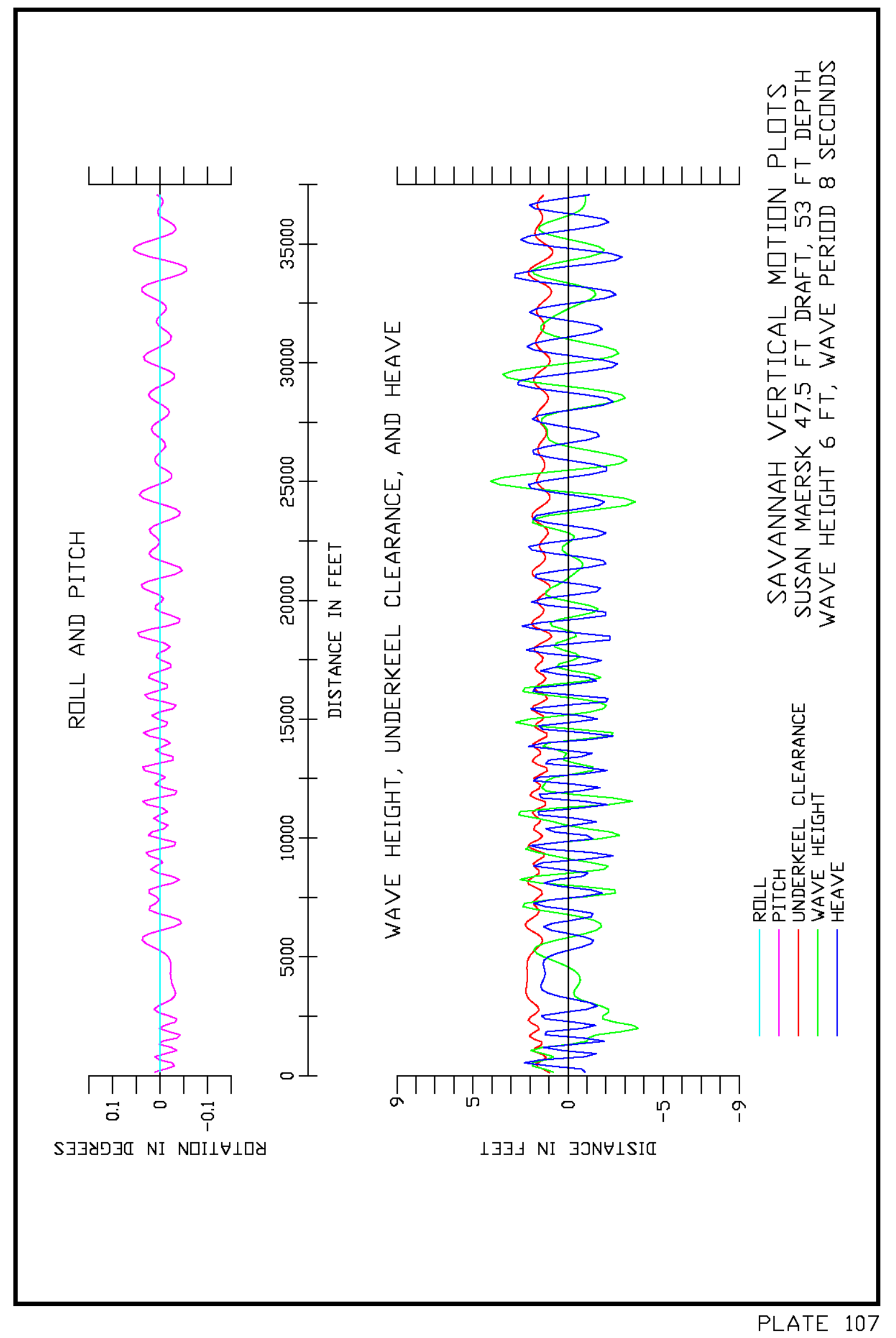




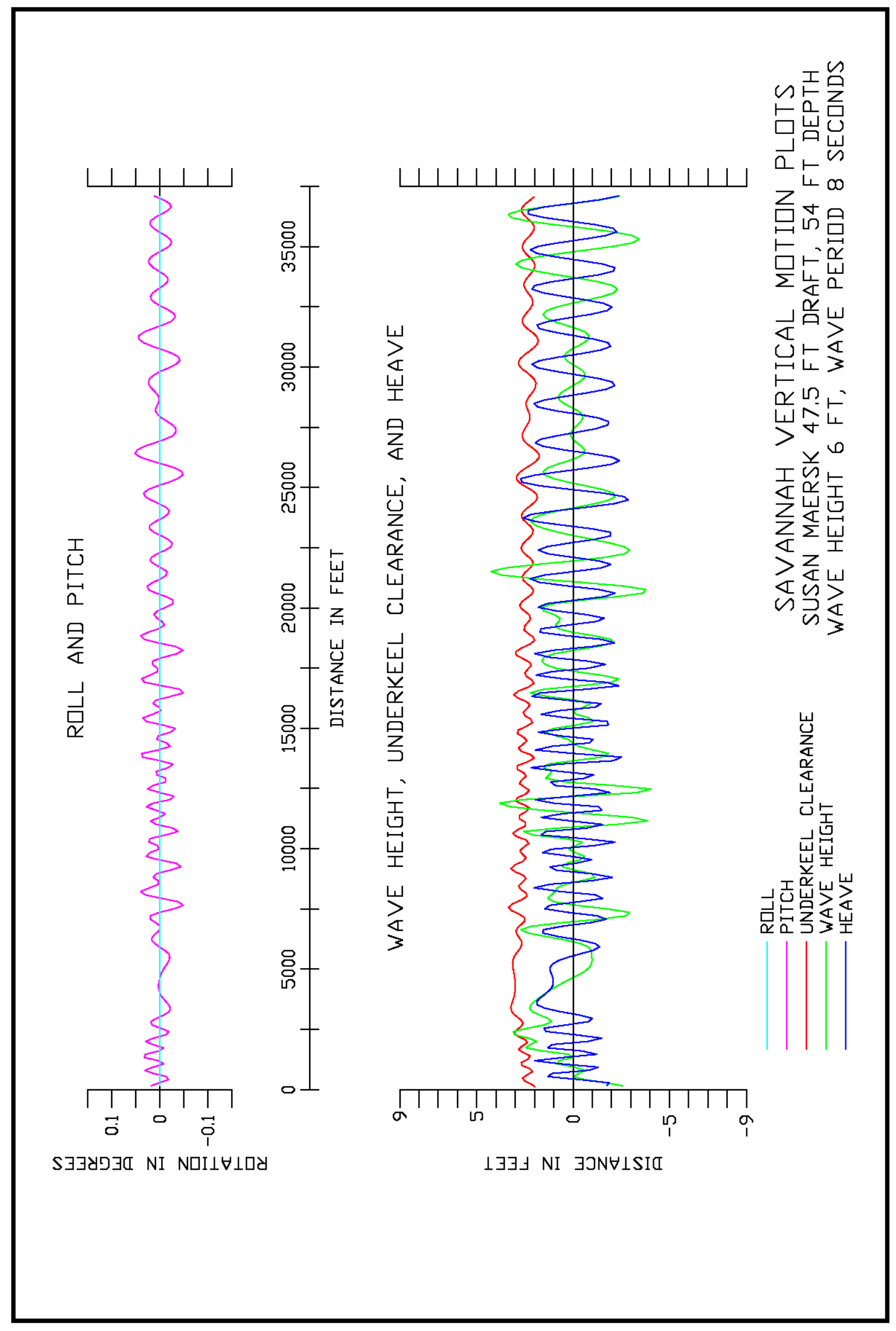

PLATE 108 


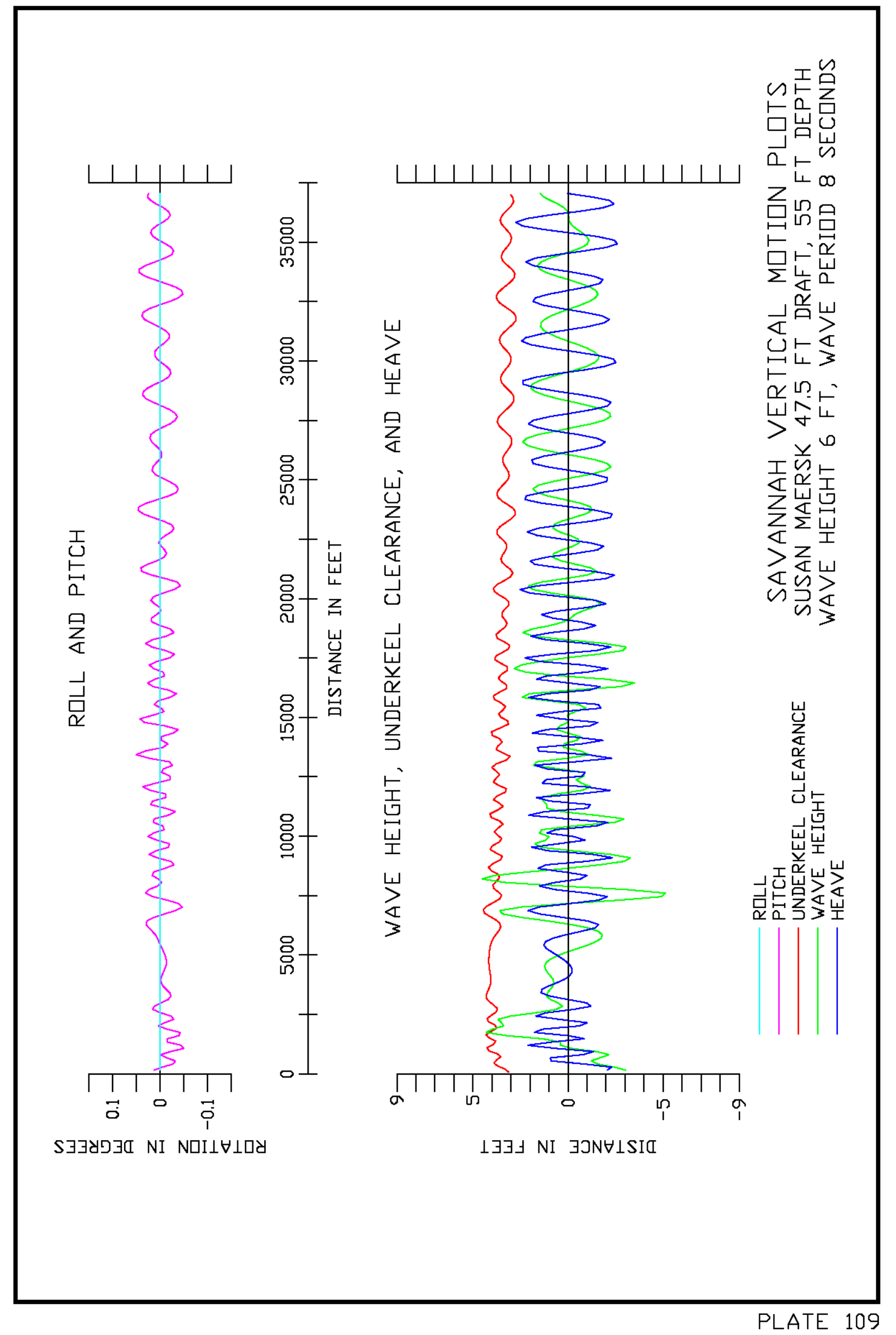




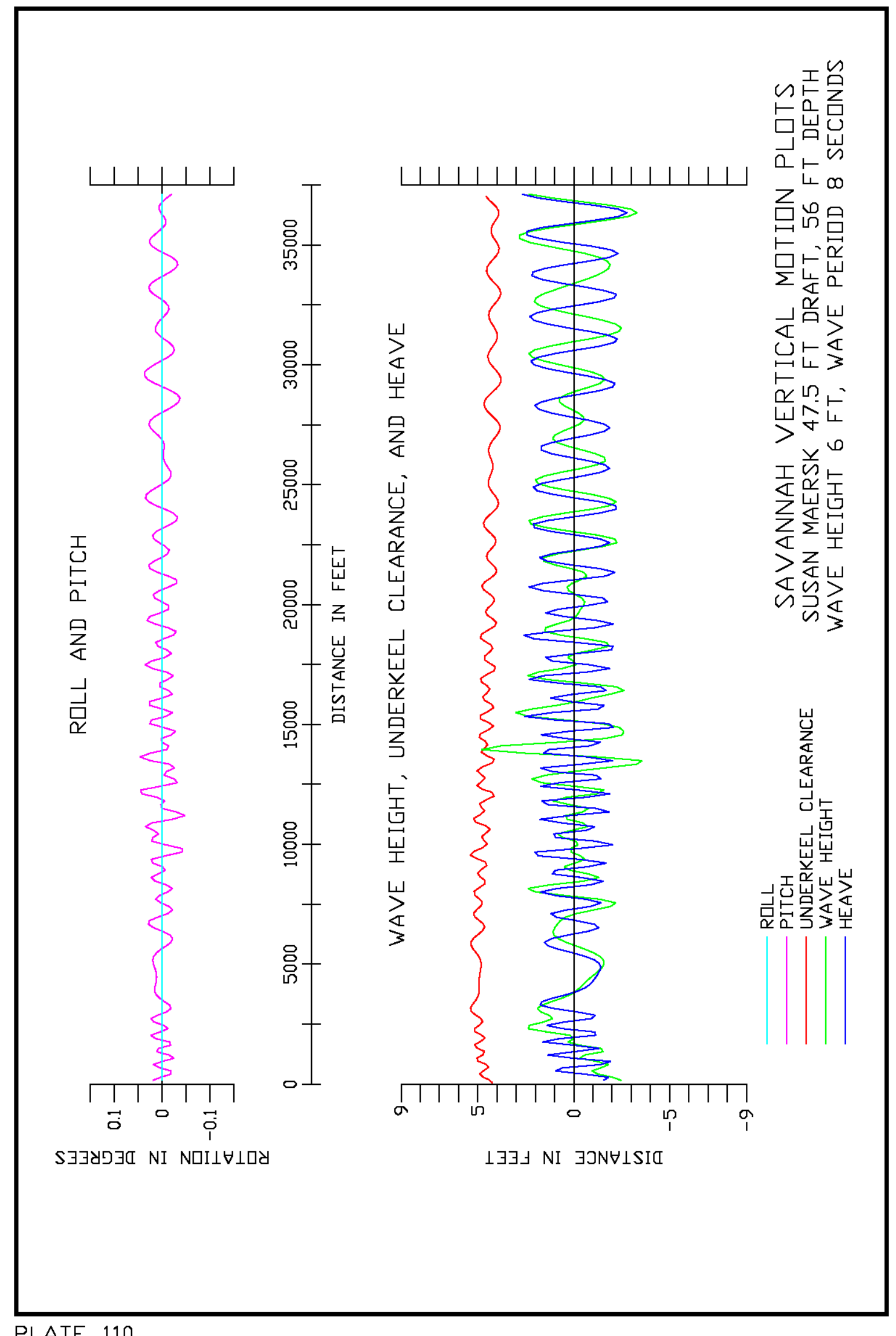

PLATE 110 


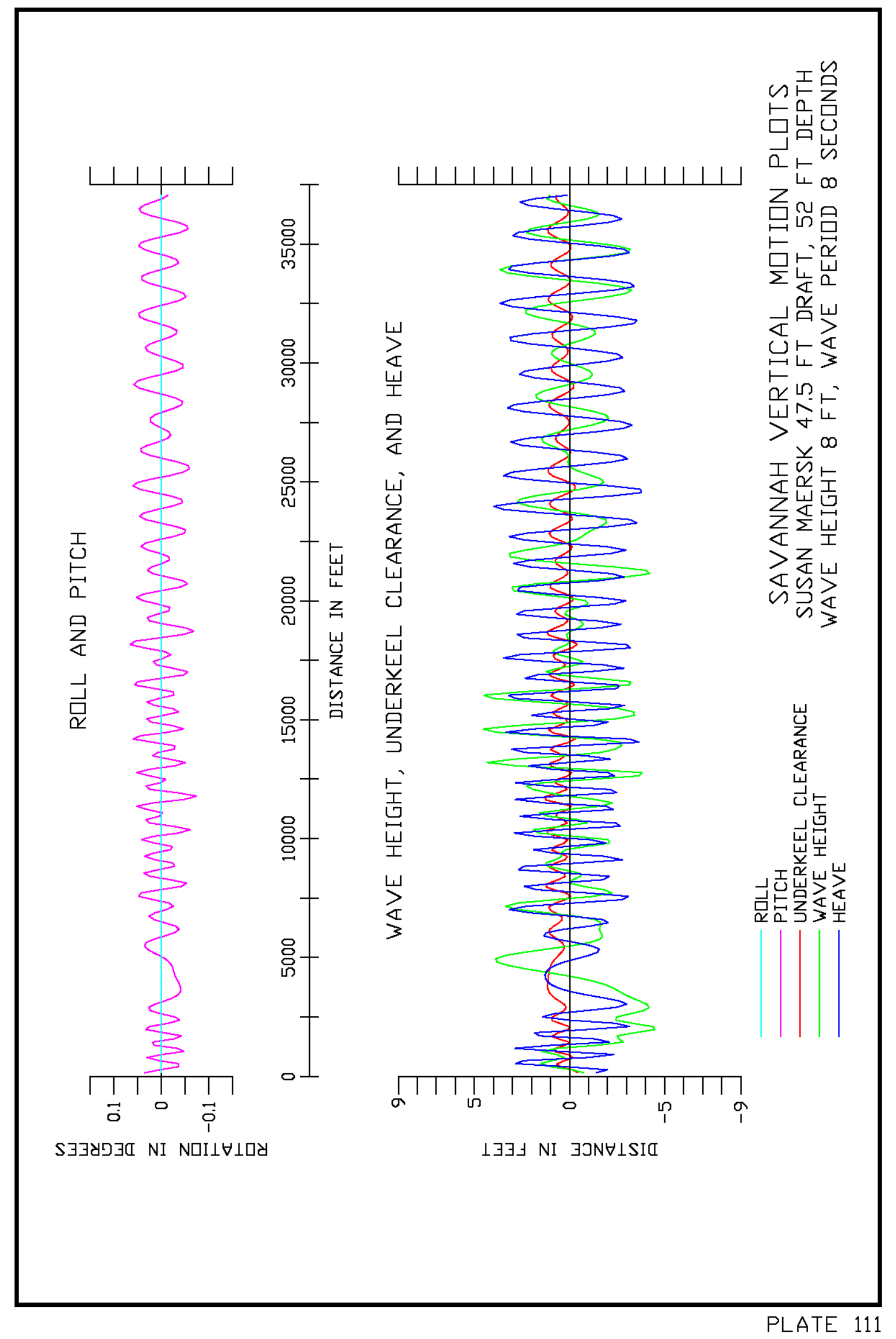




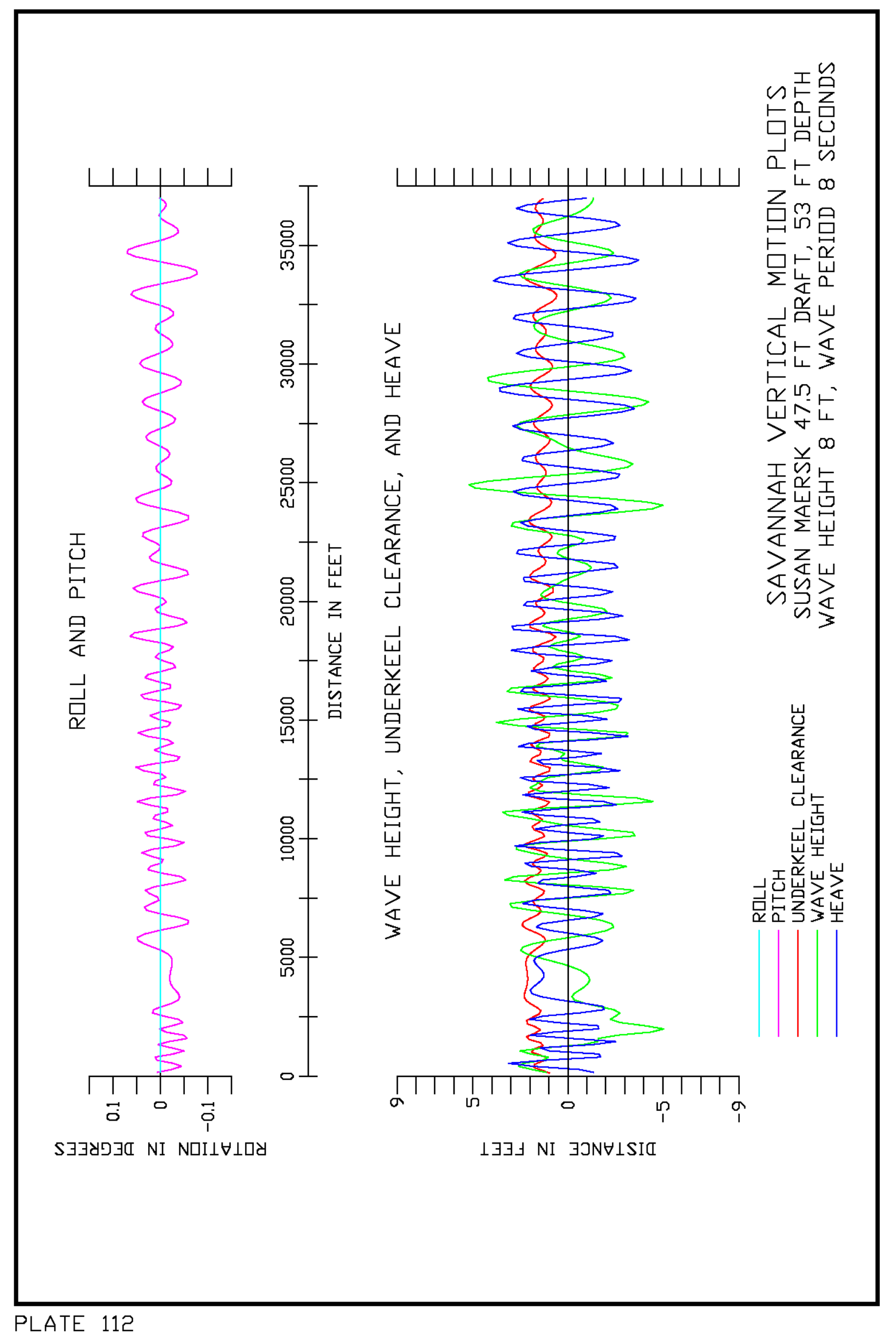




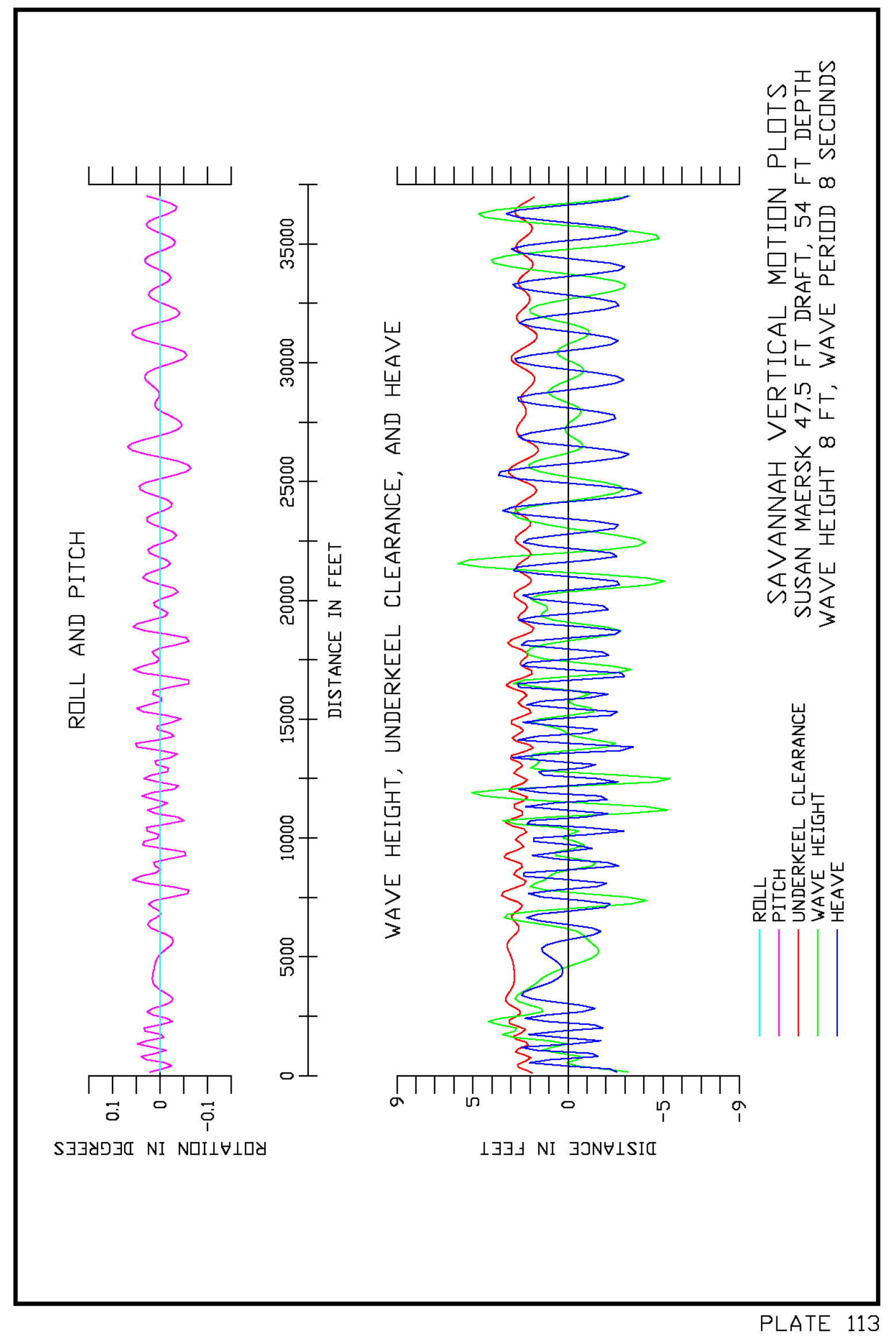




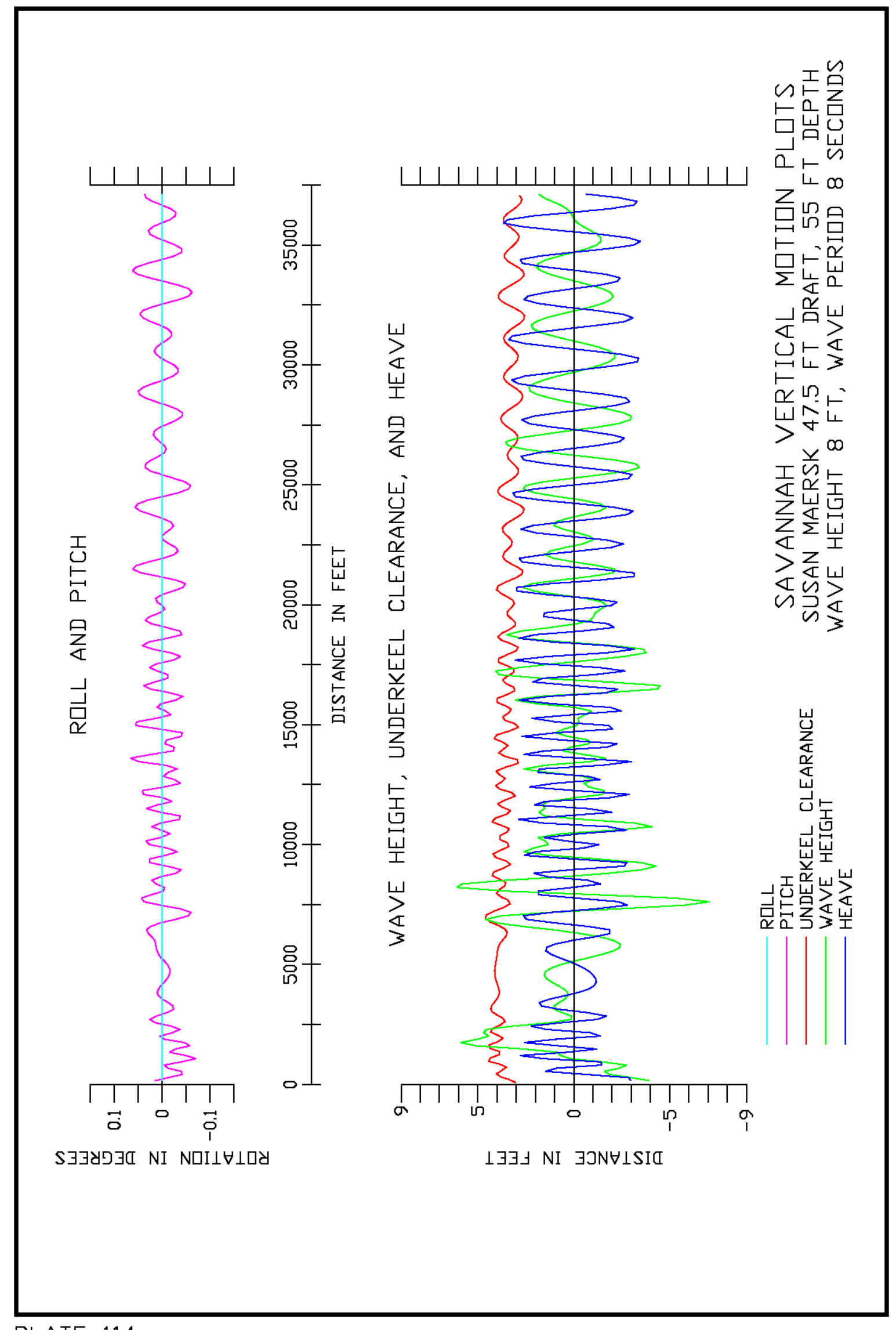

PLATE 114 


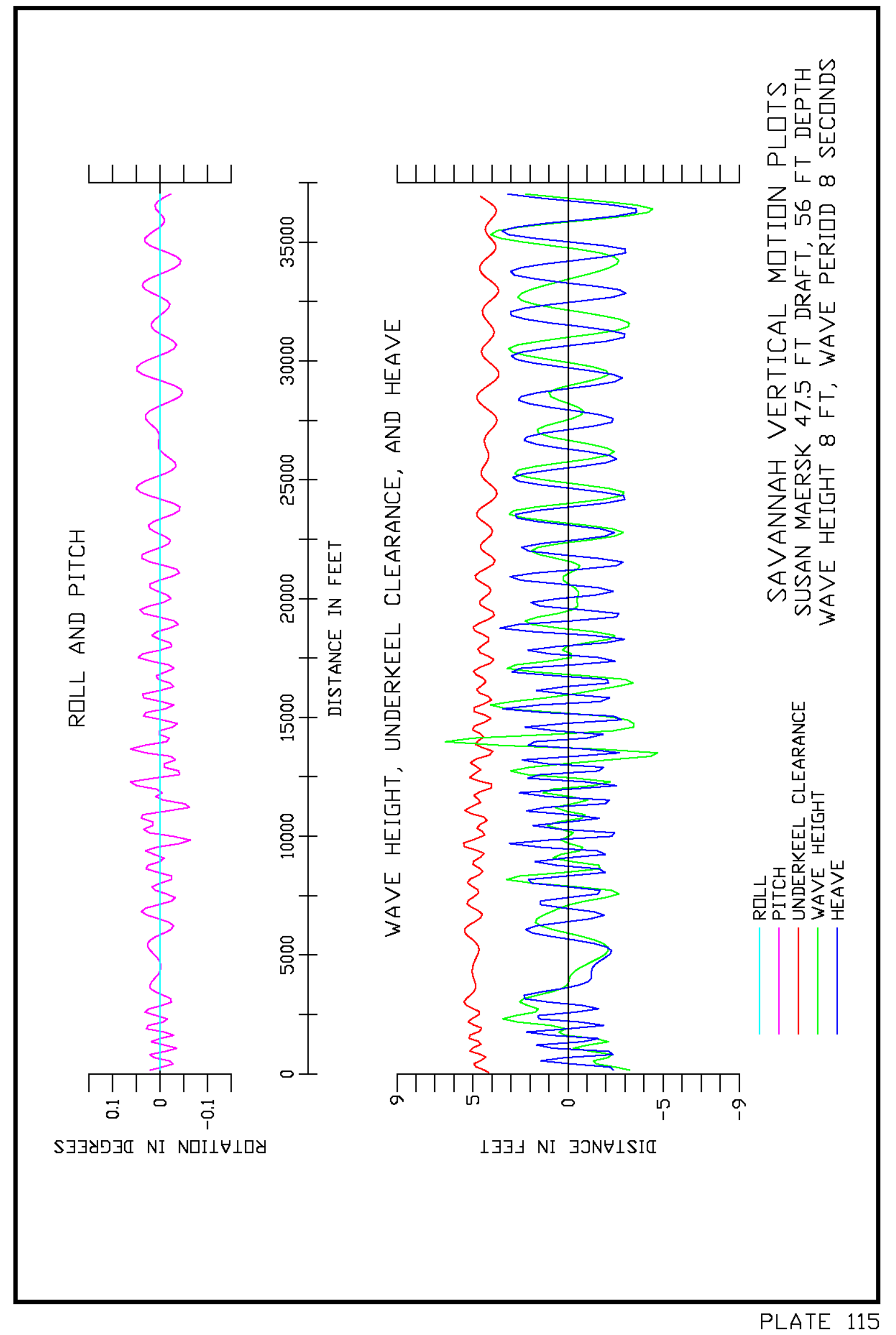




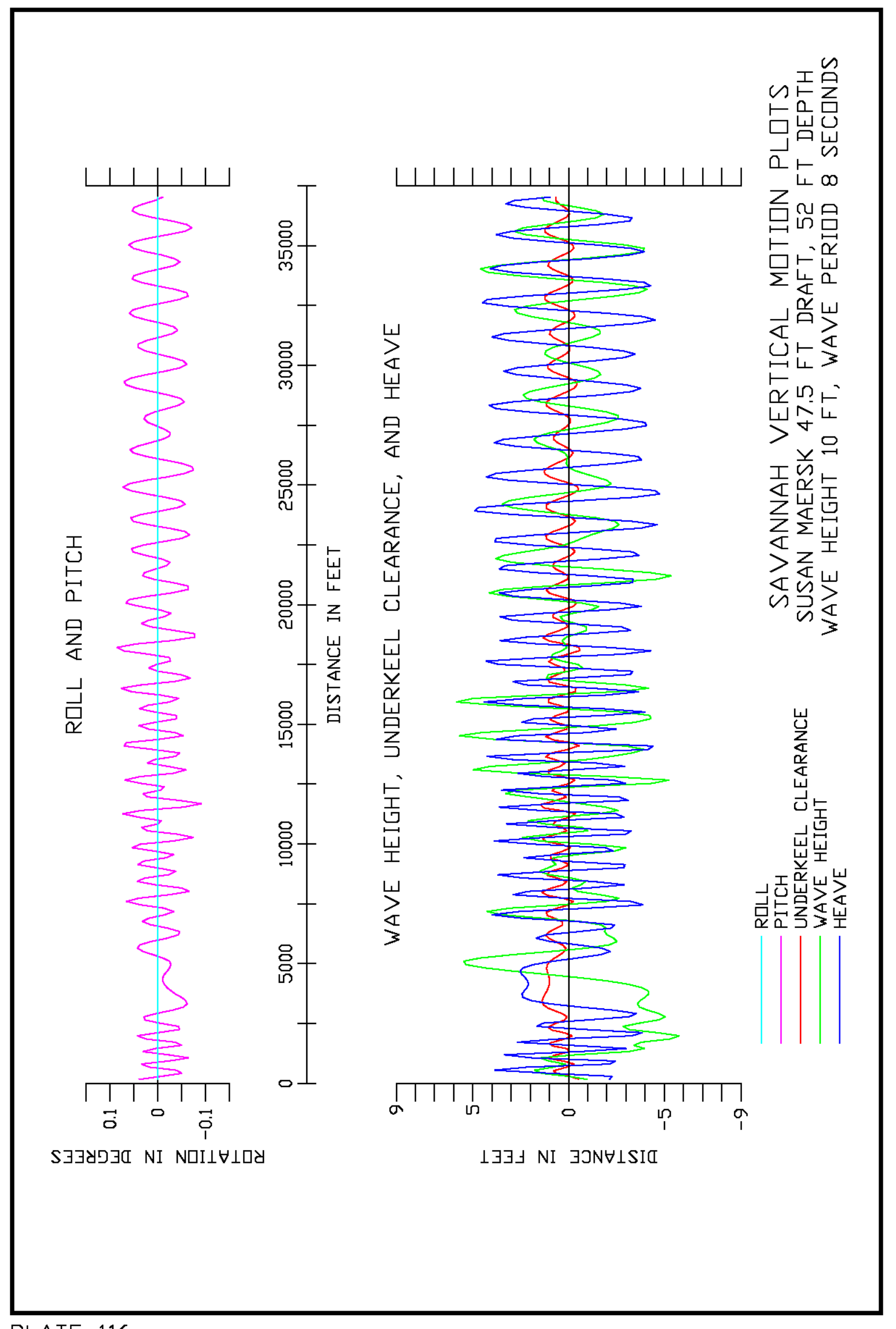

PLATE 116 


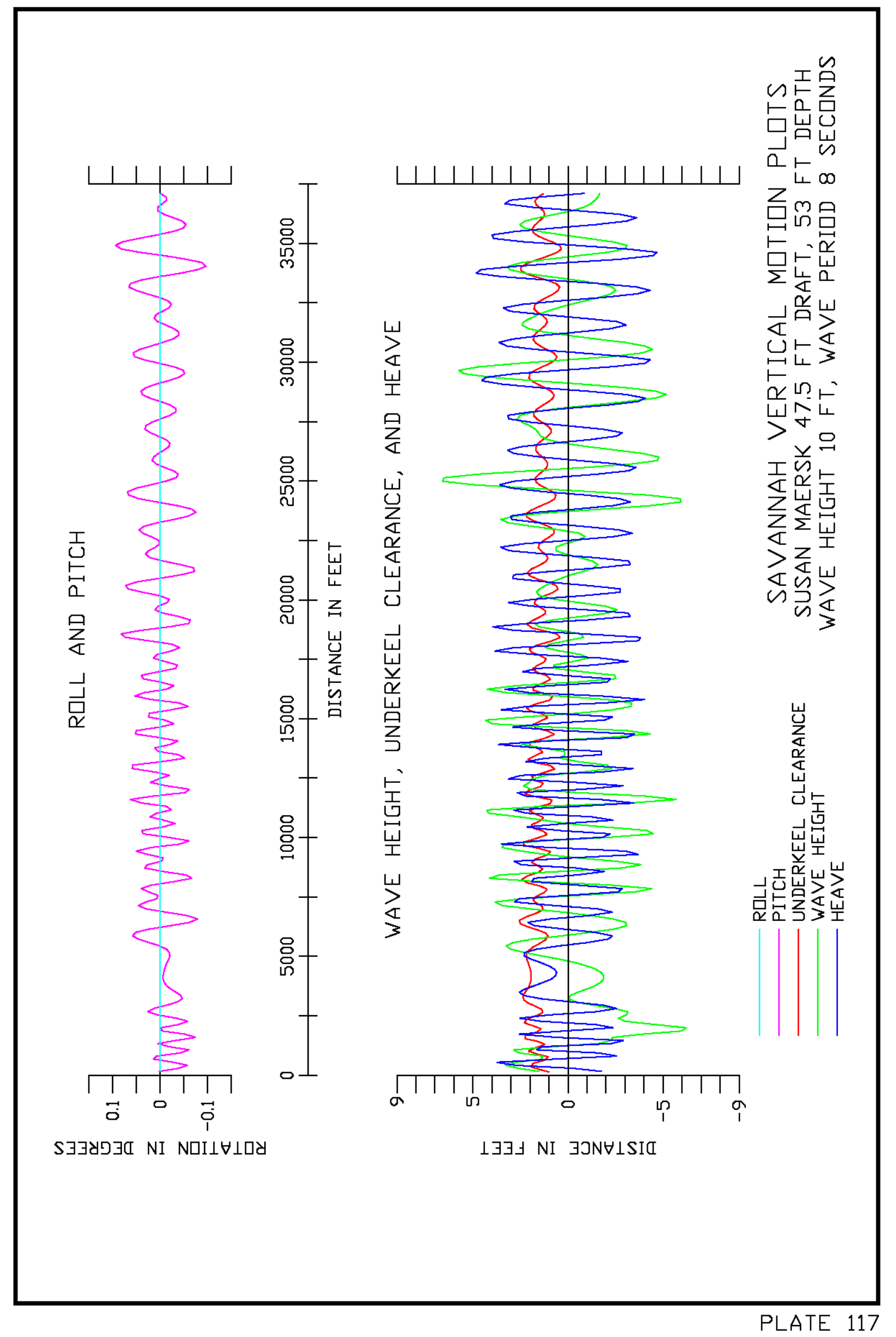




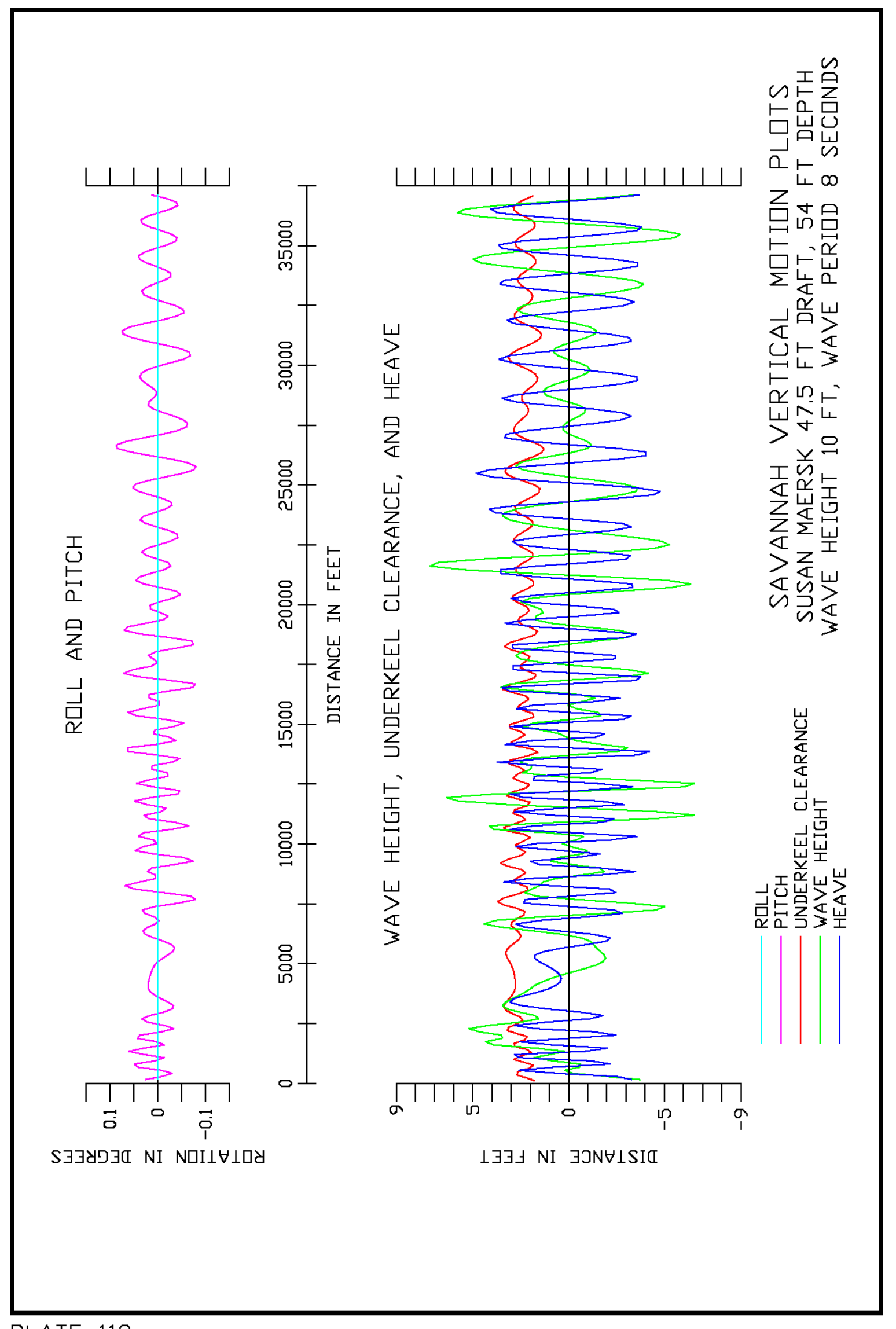

PLATE 118 


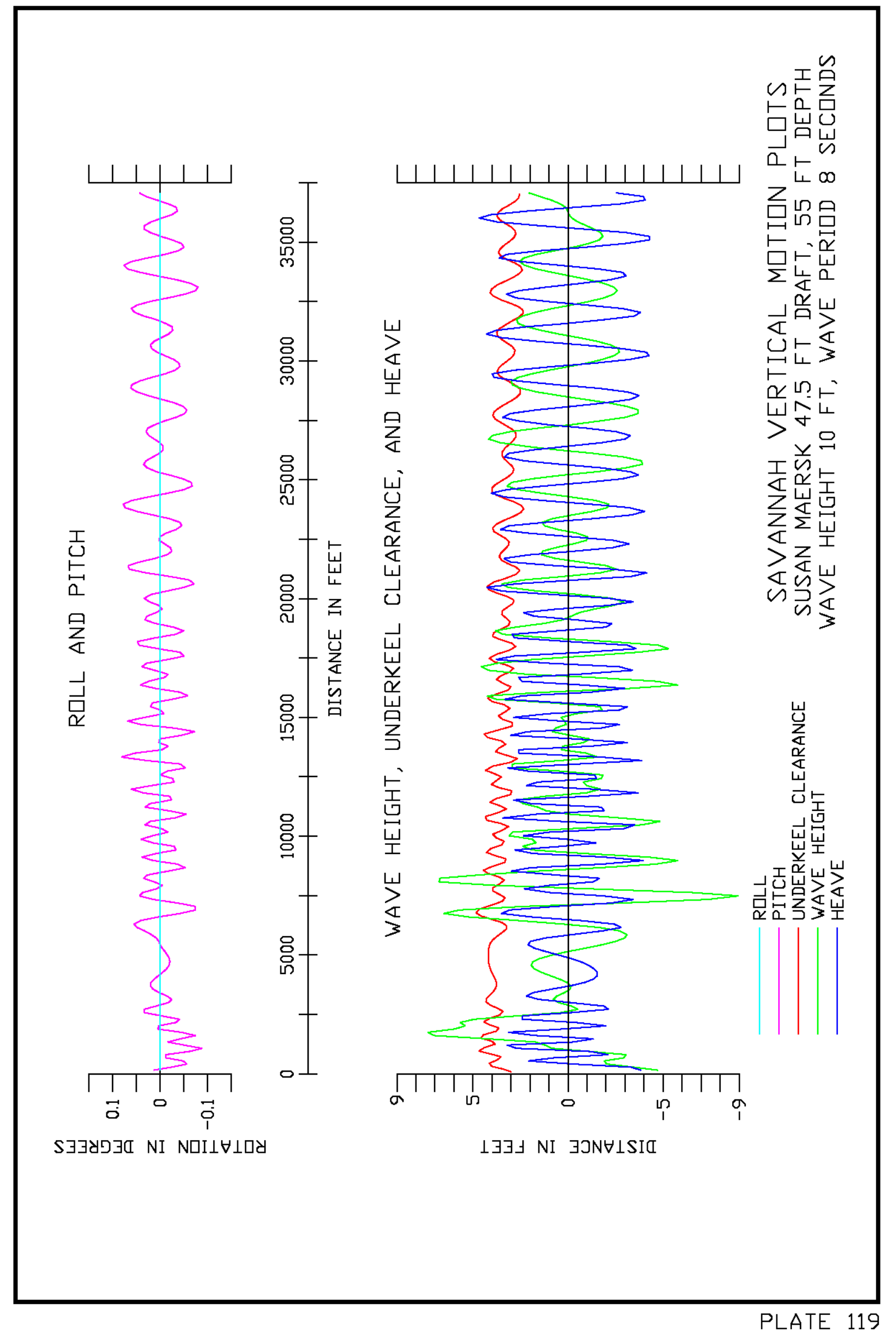




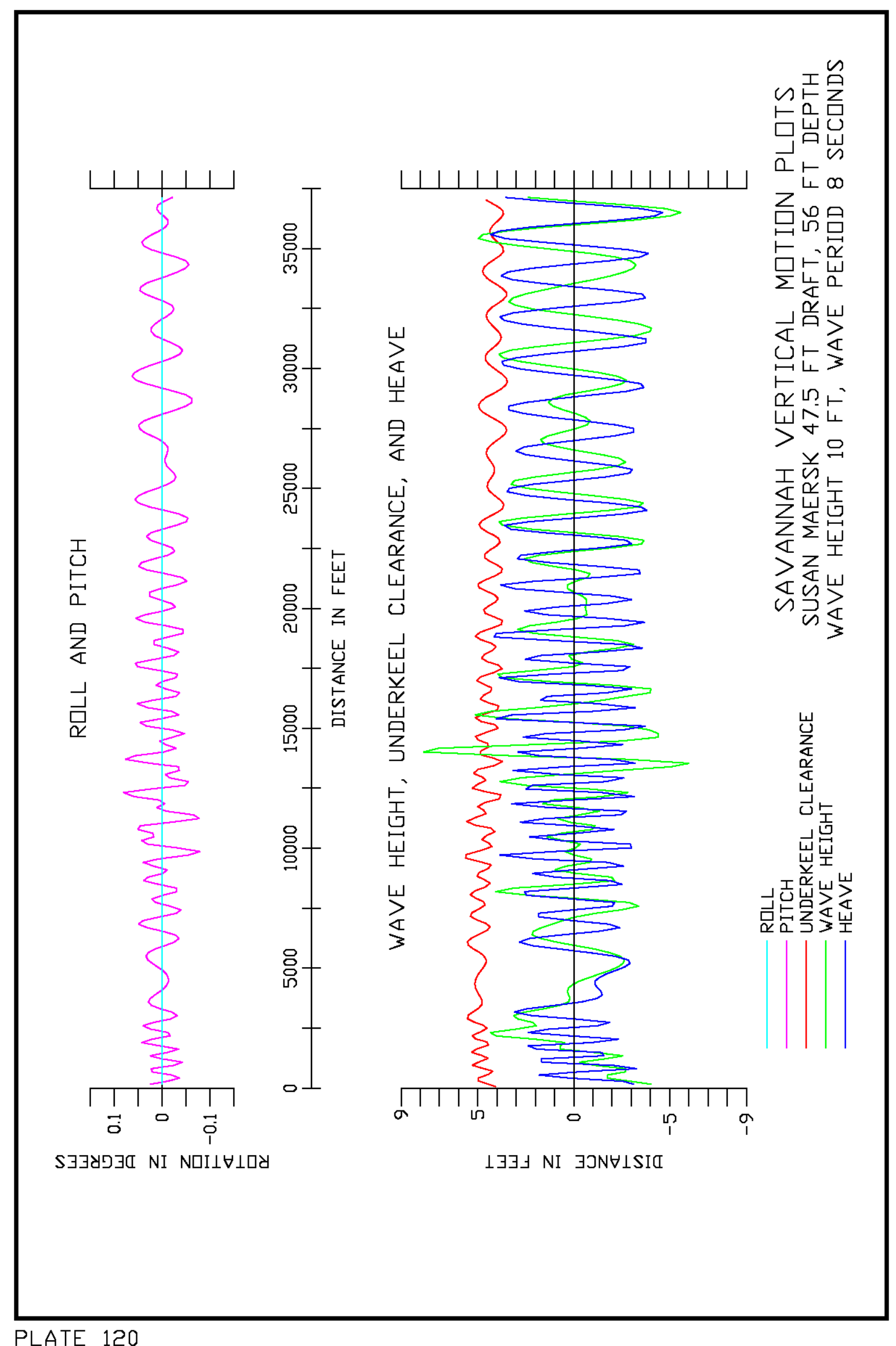




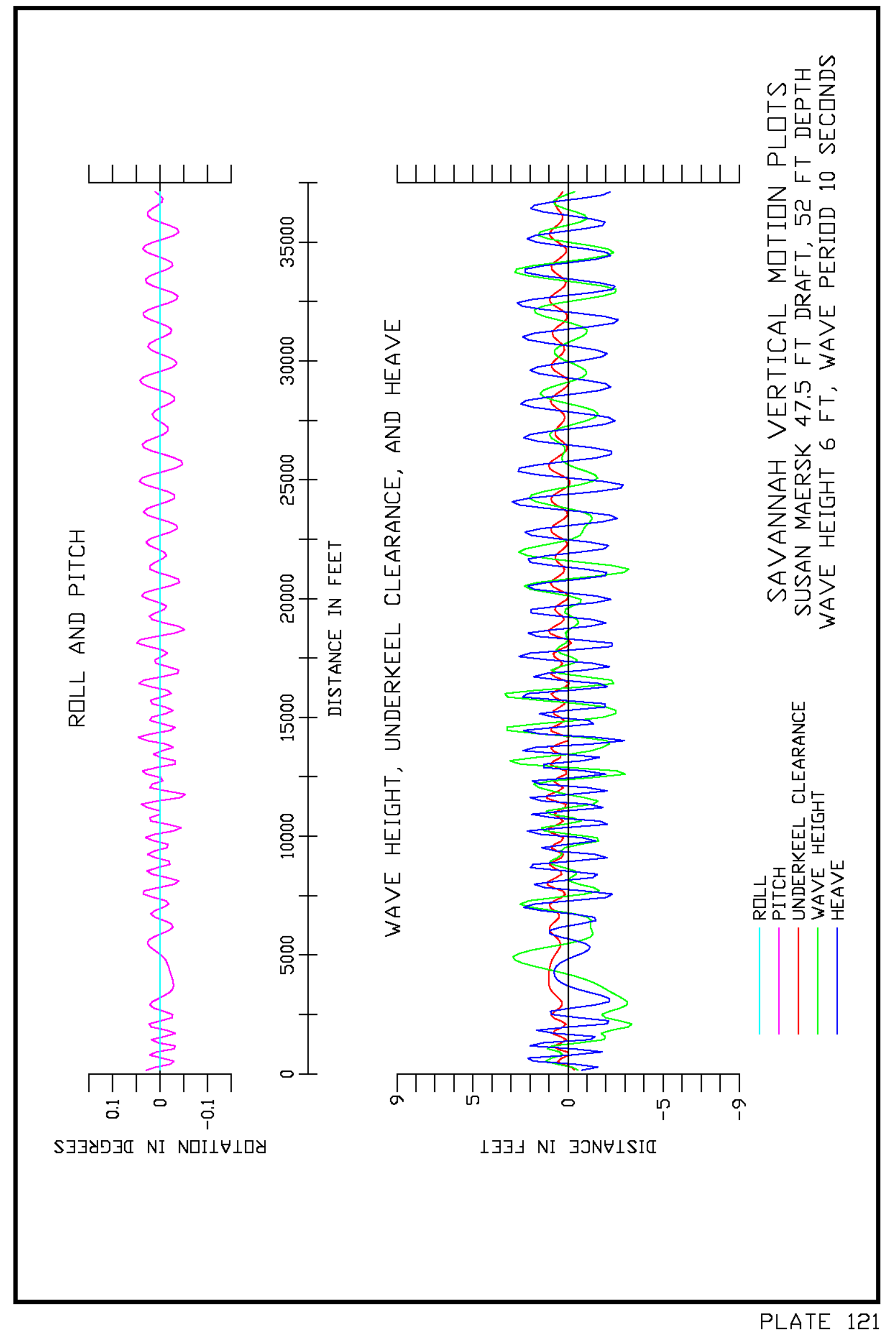




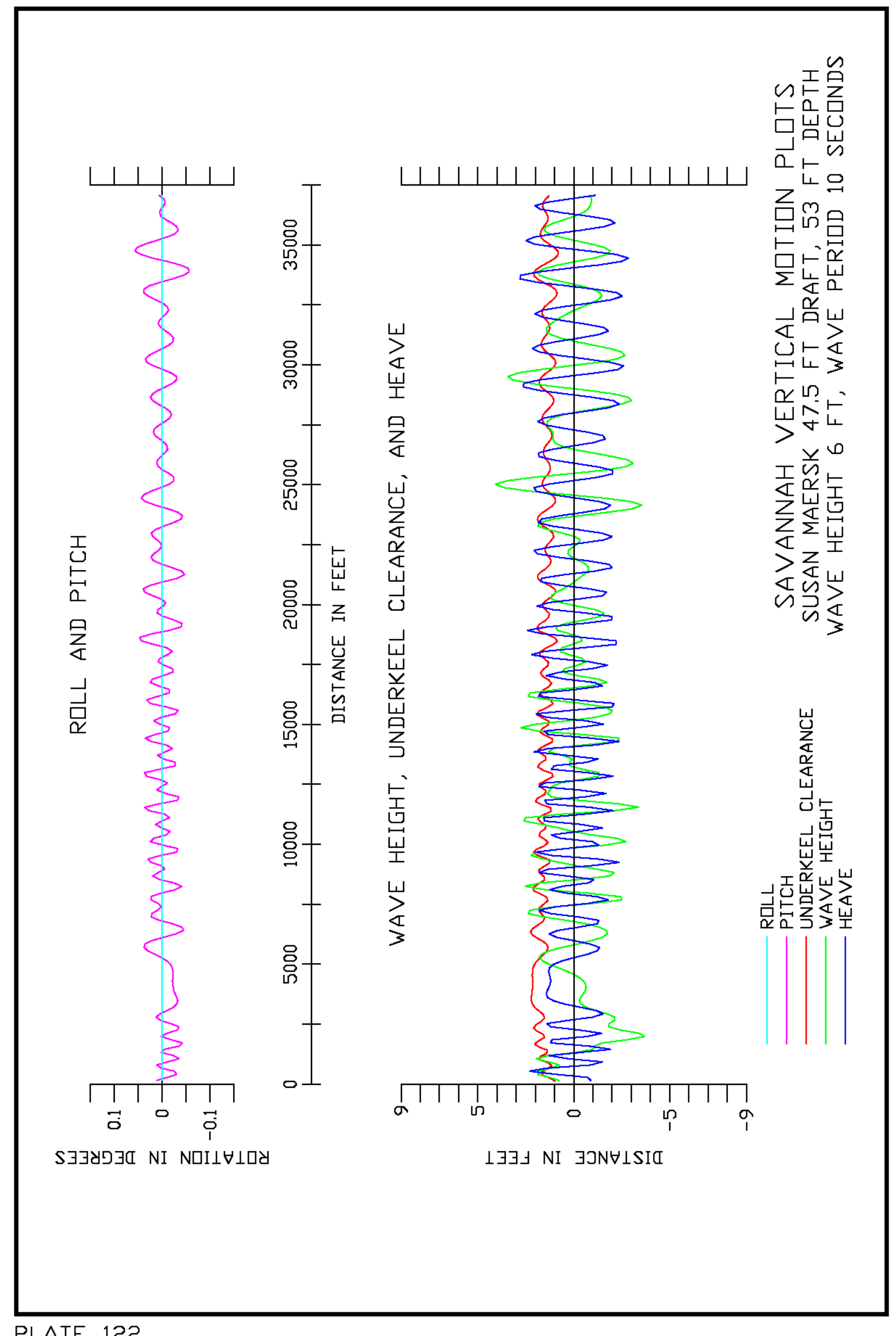

PLATE 122 


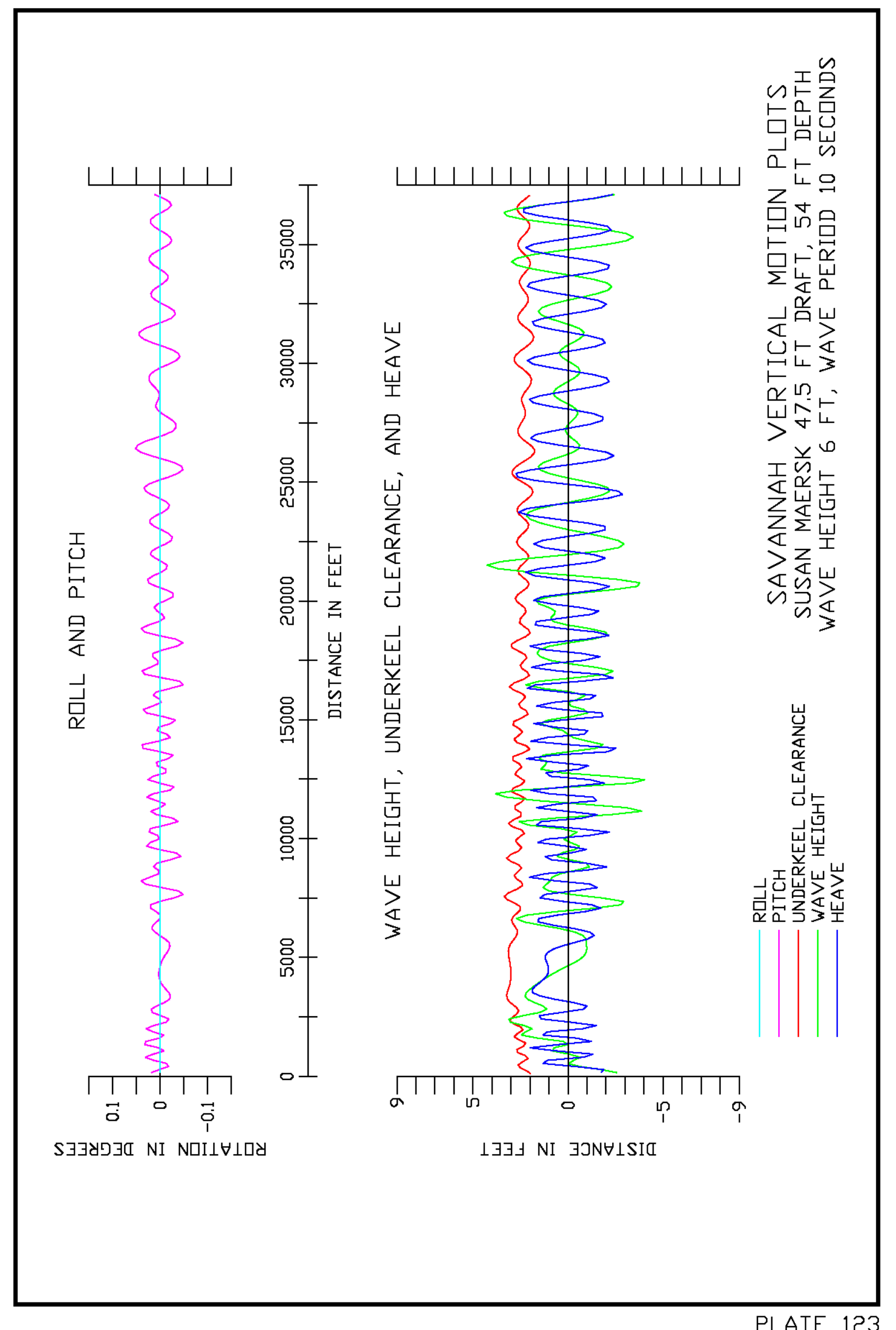




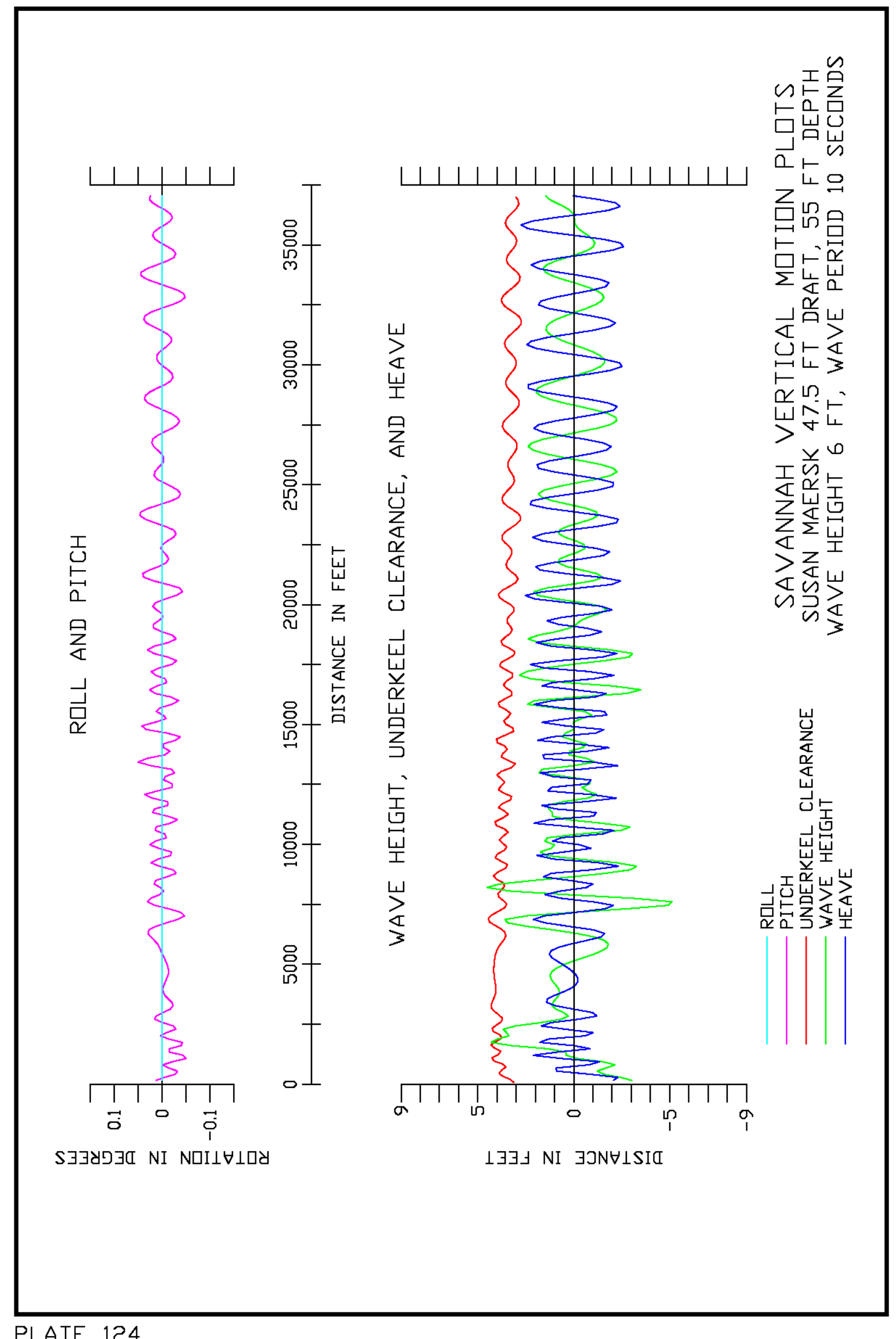

PLATE 124 


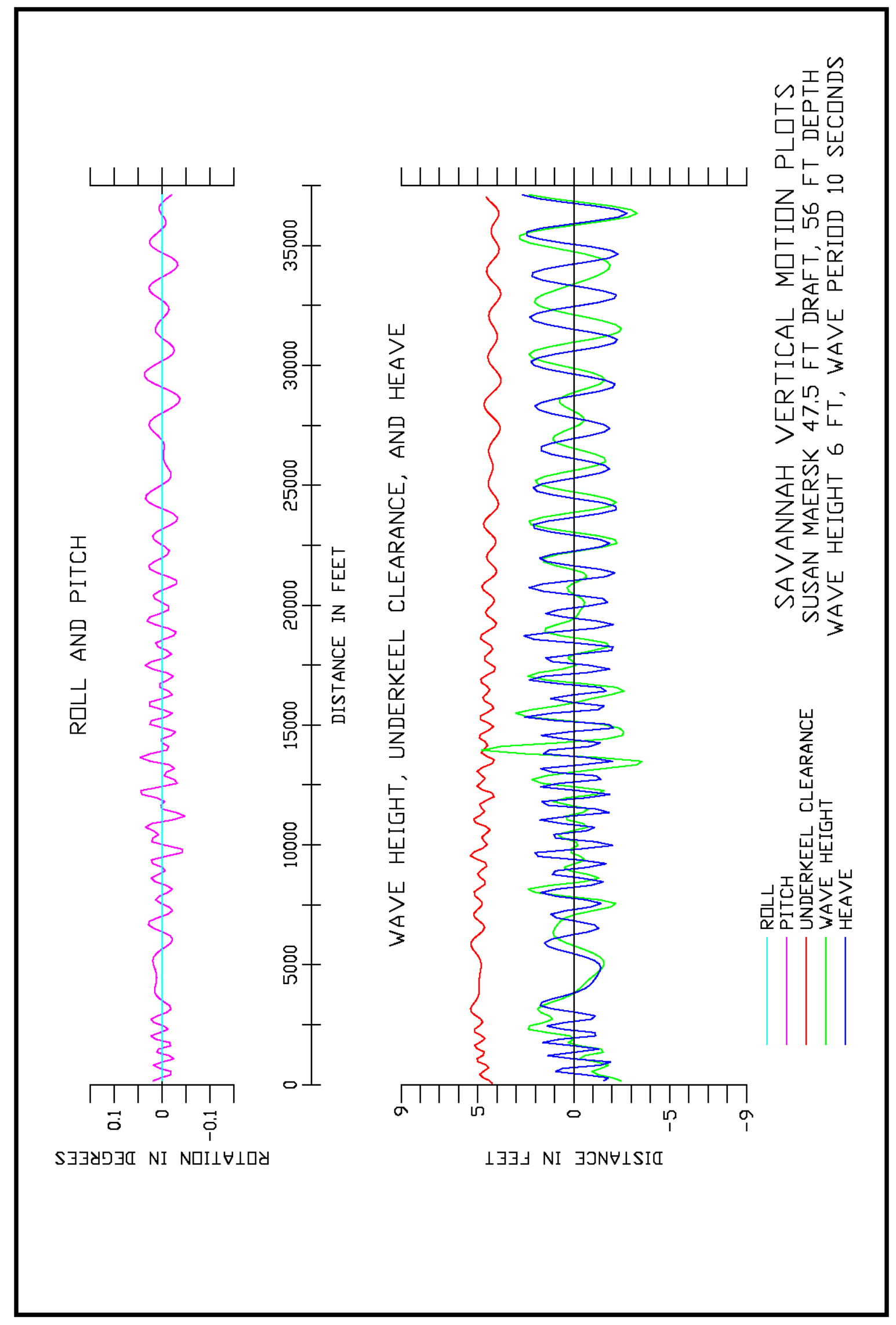




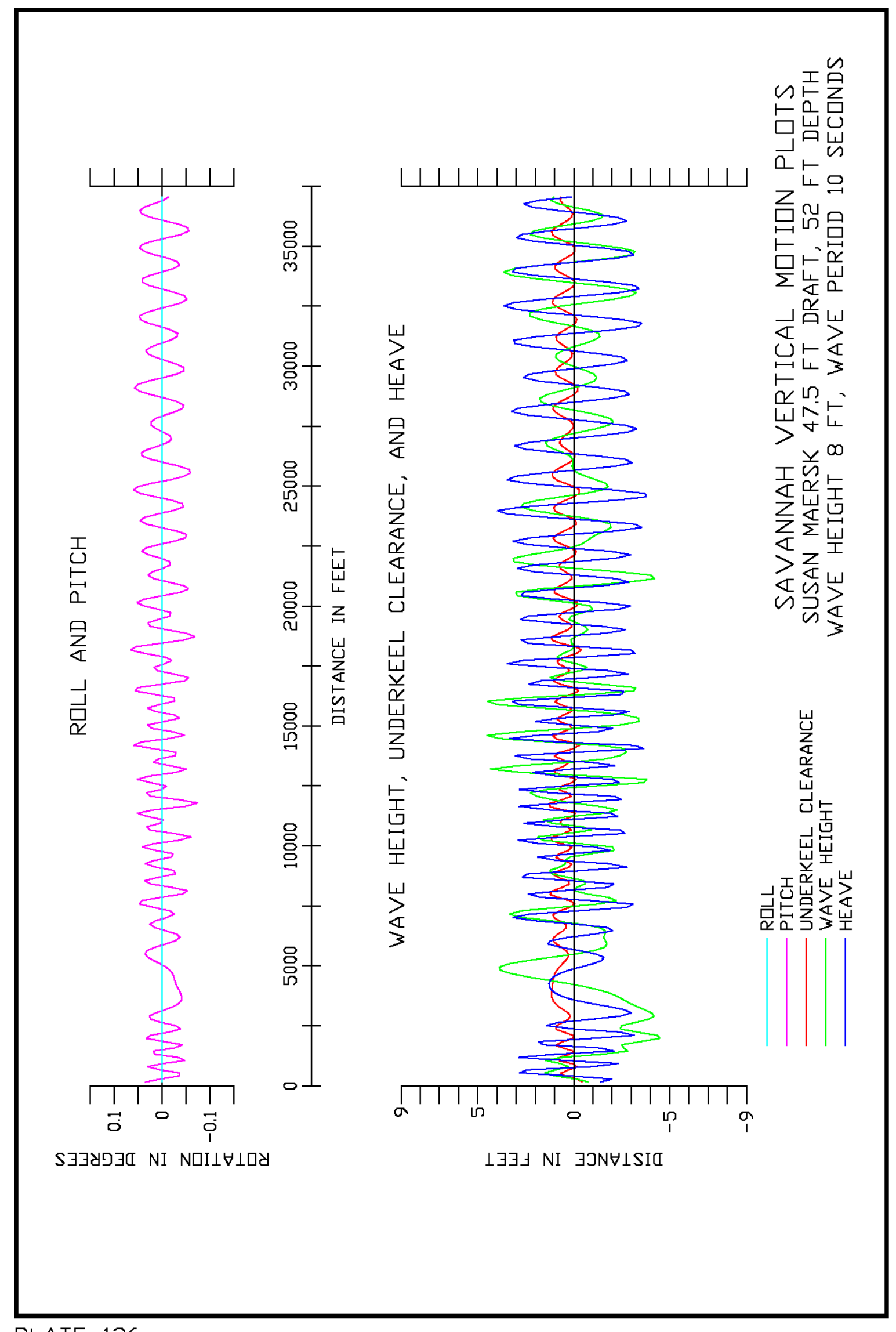

PLATE 126 


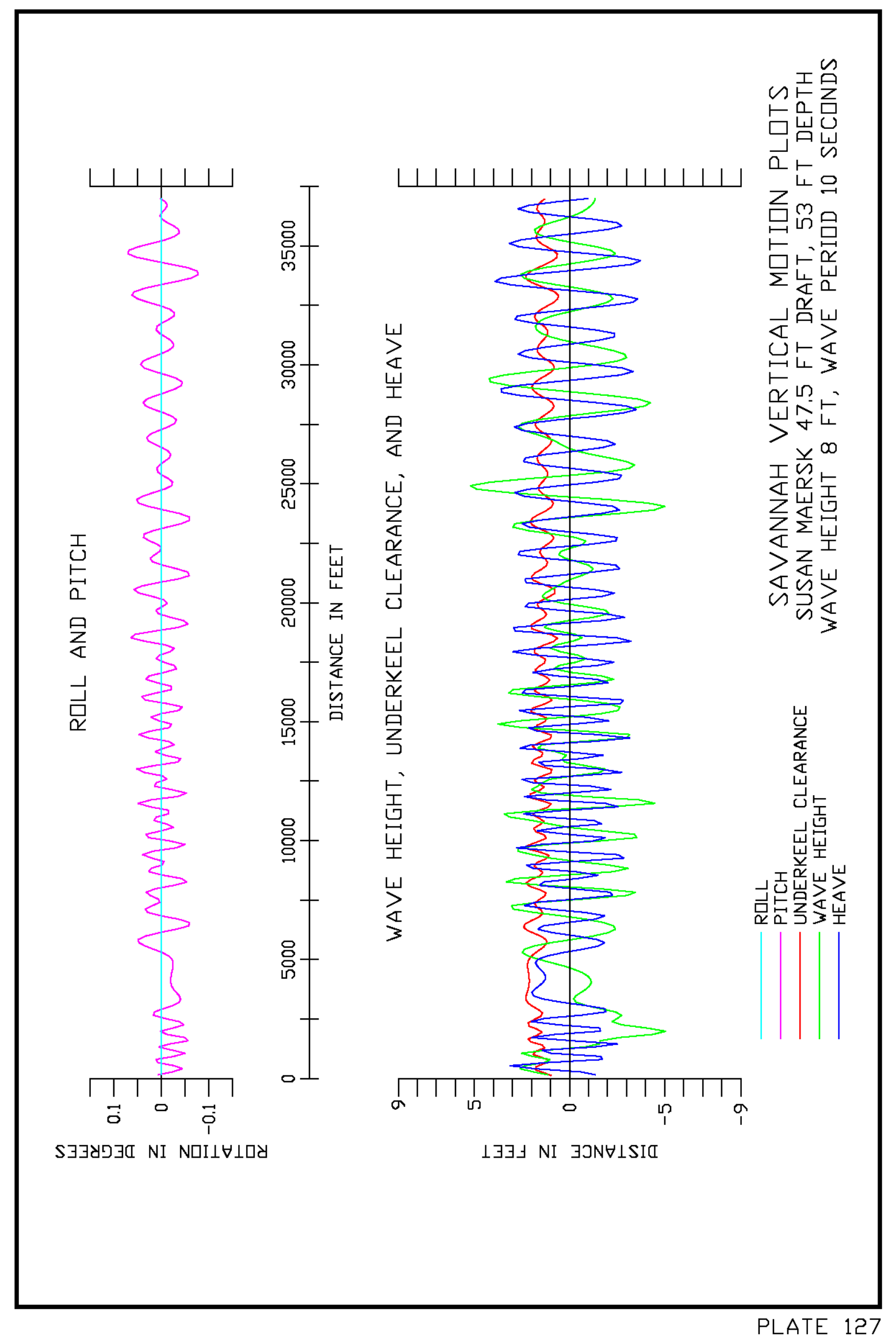




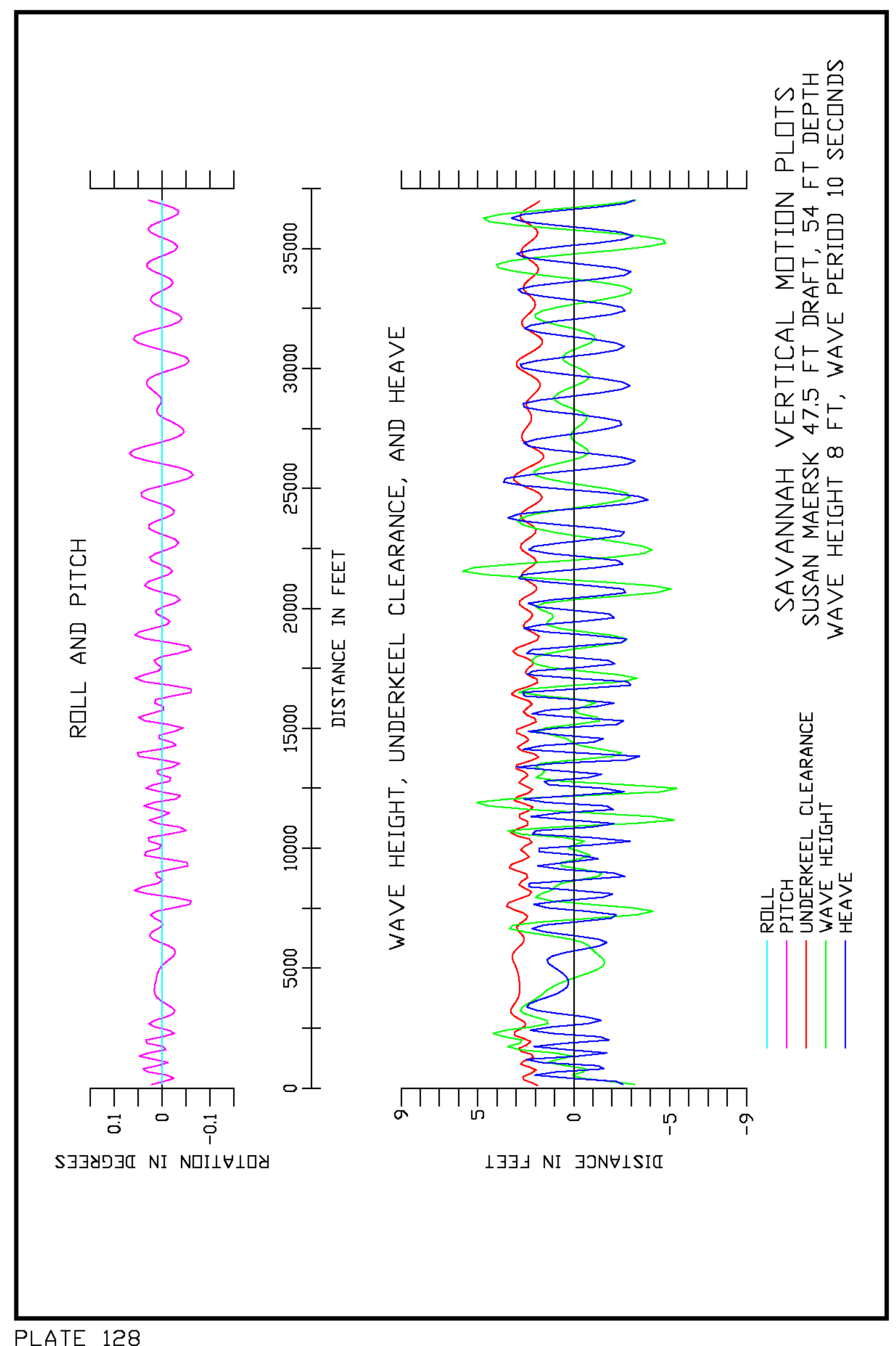

PLATE 128 


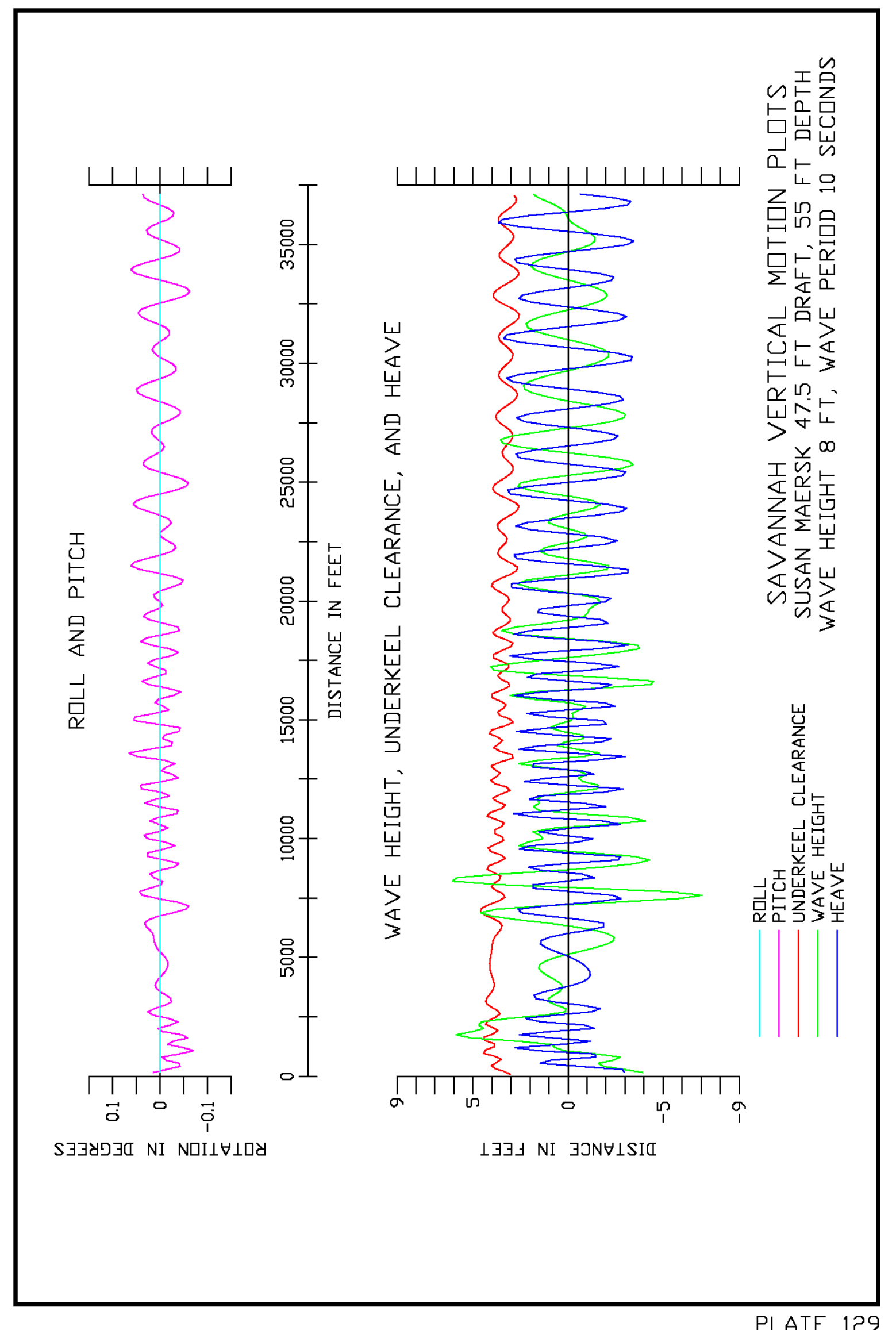




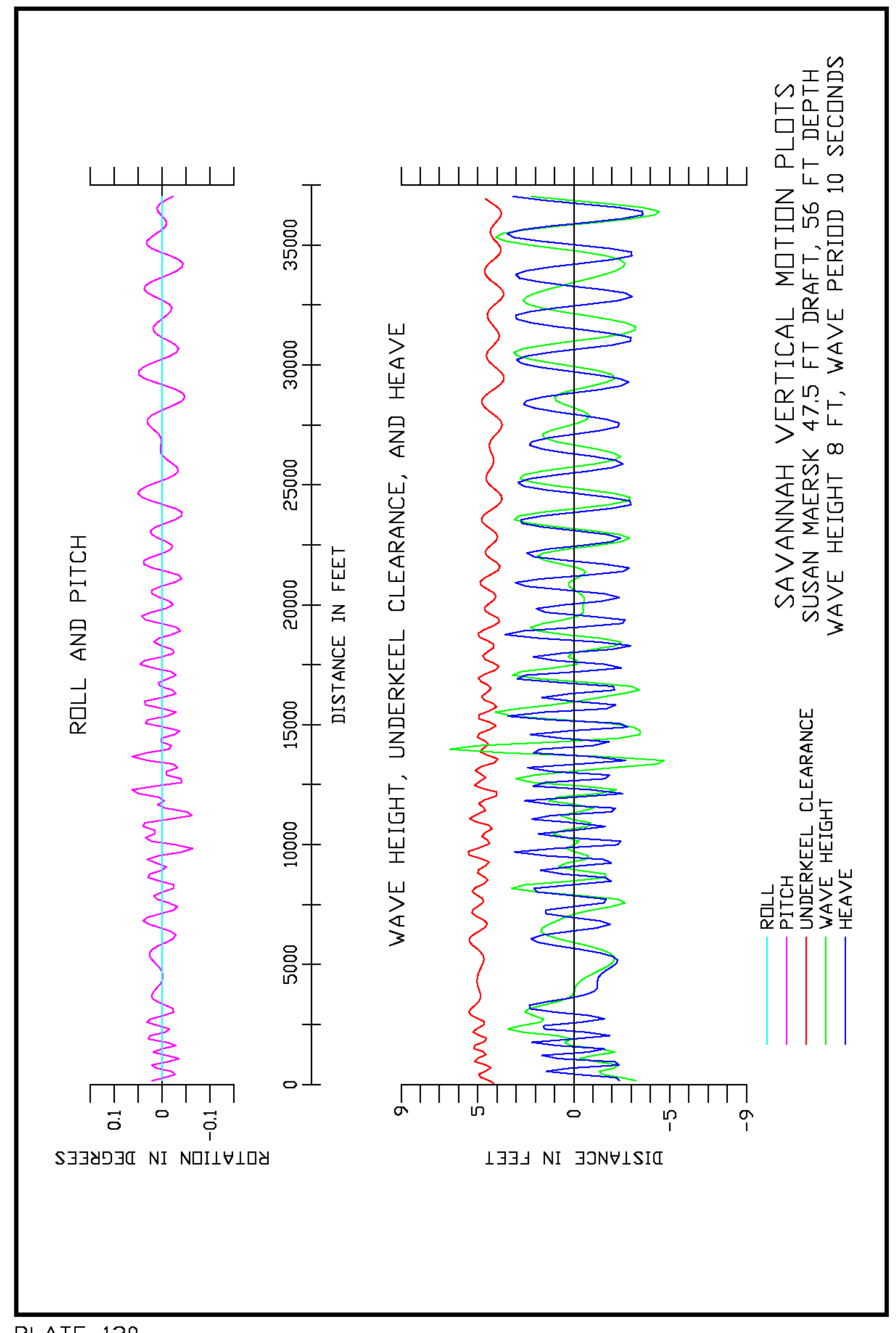

PLATE 130 


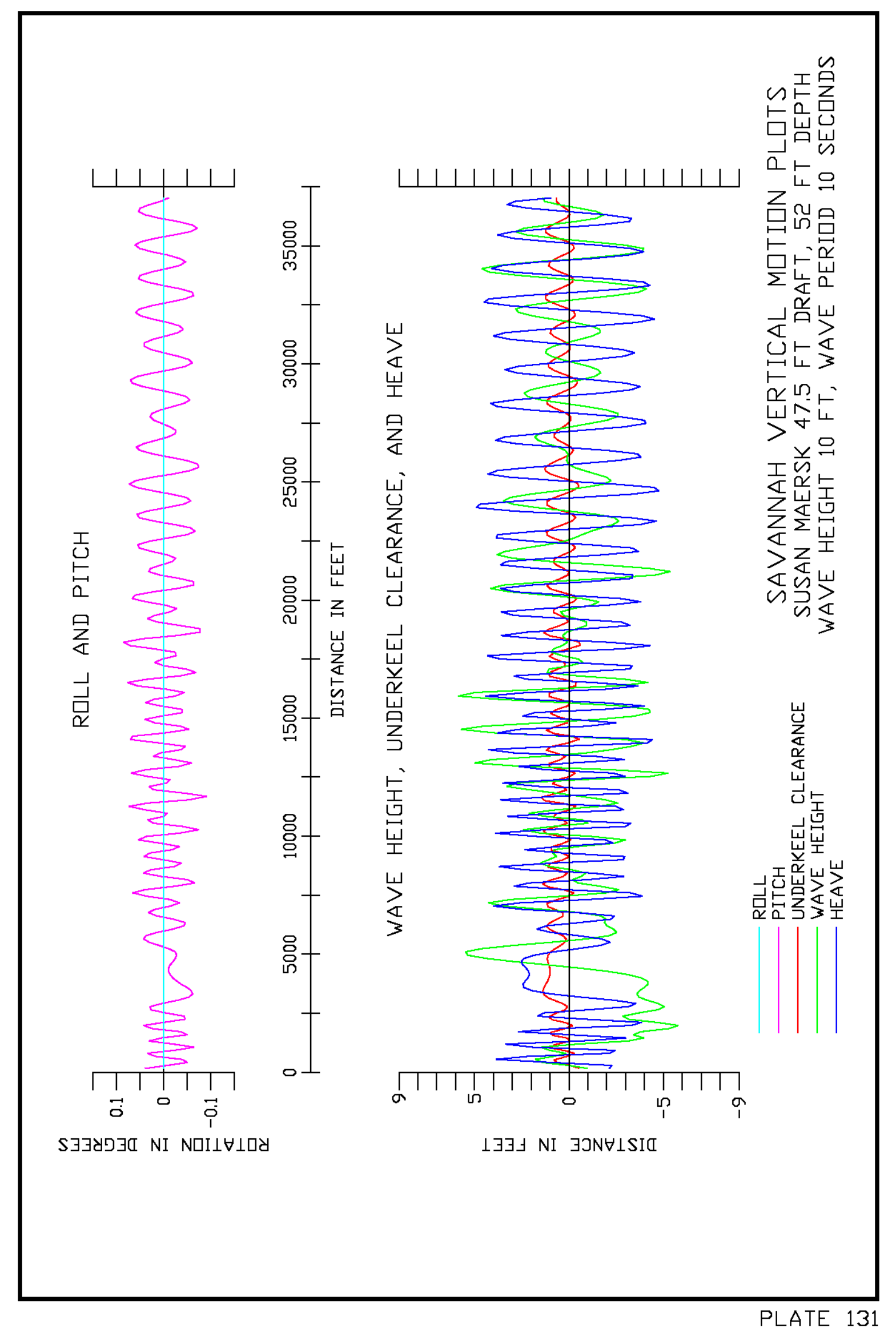




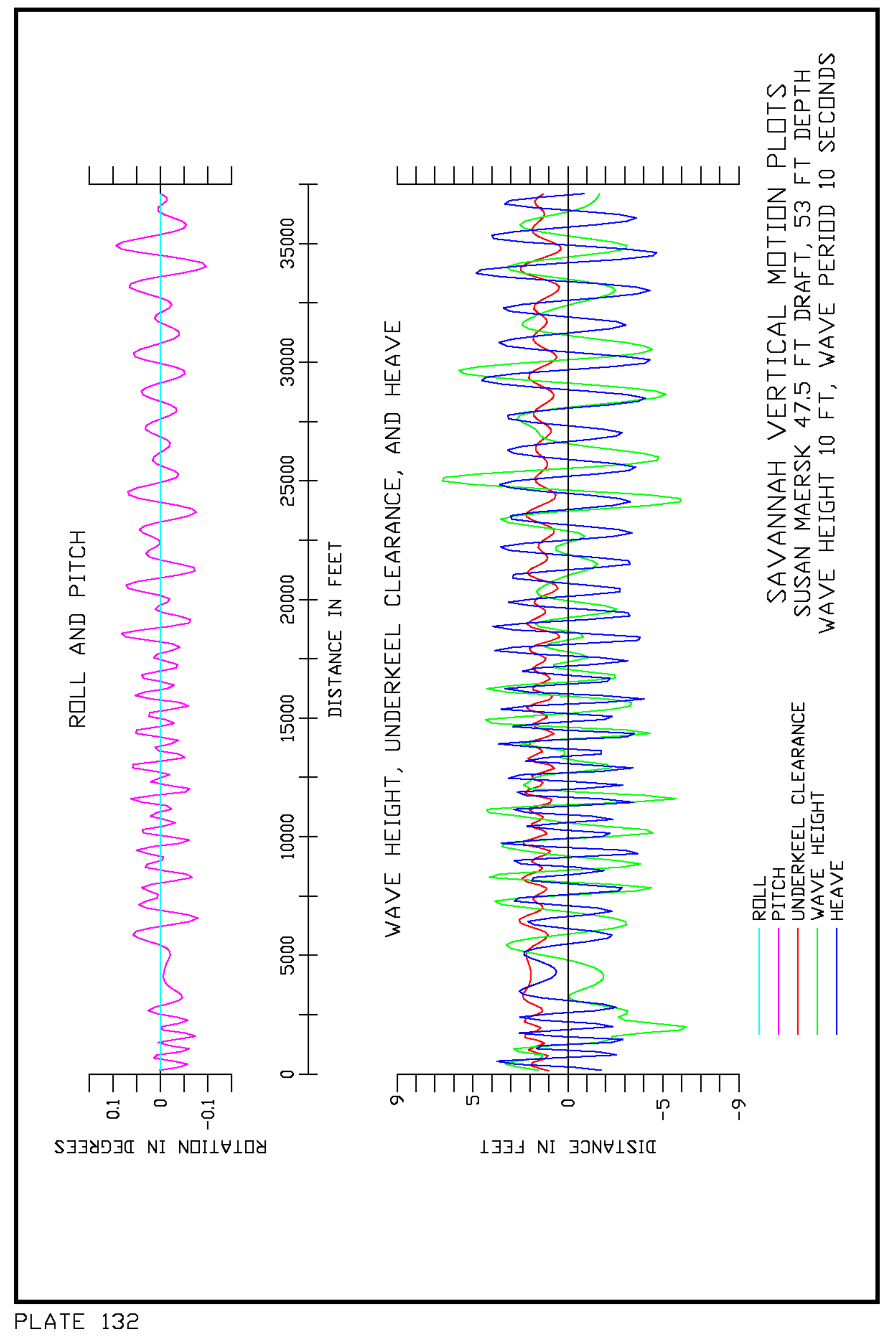




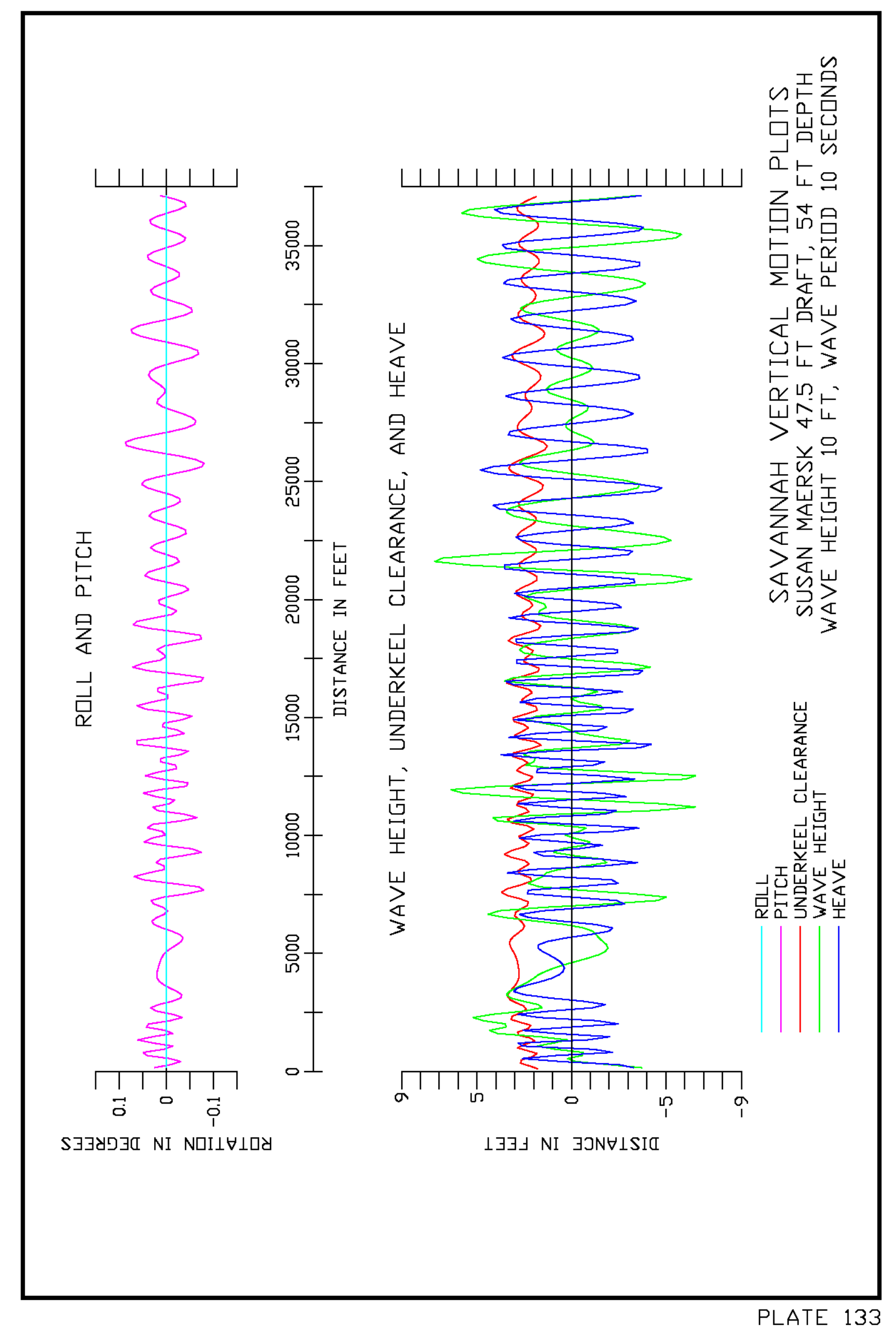




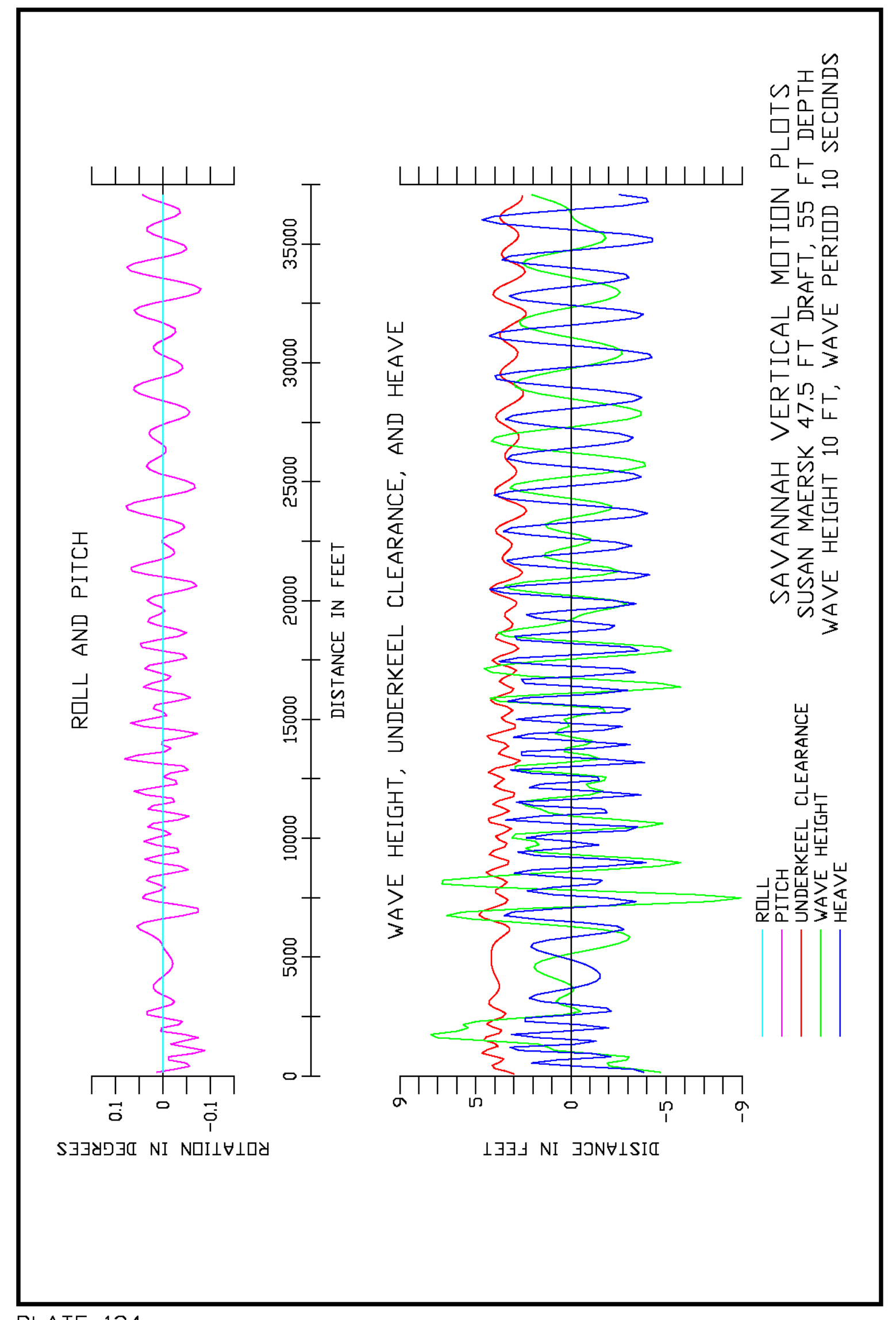

PLATE 134 


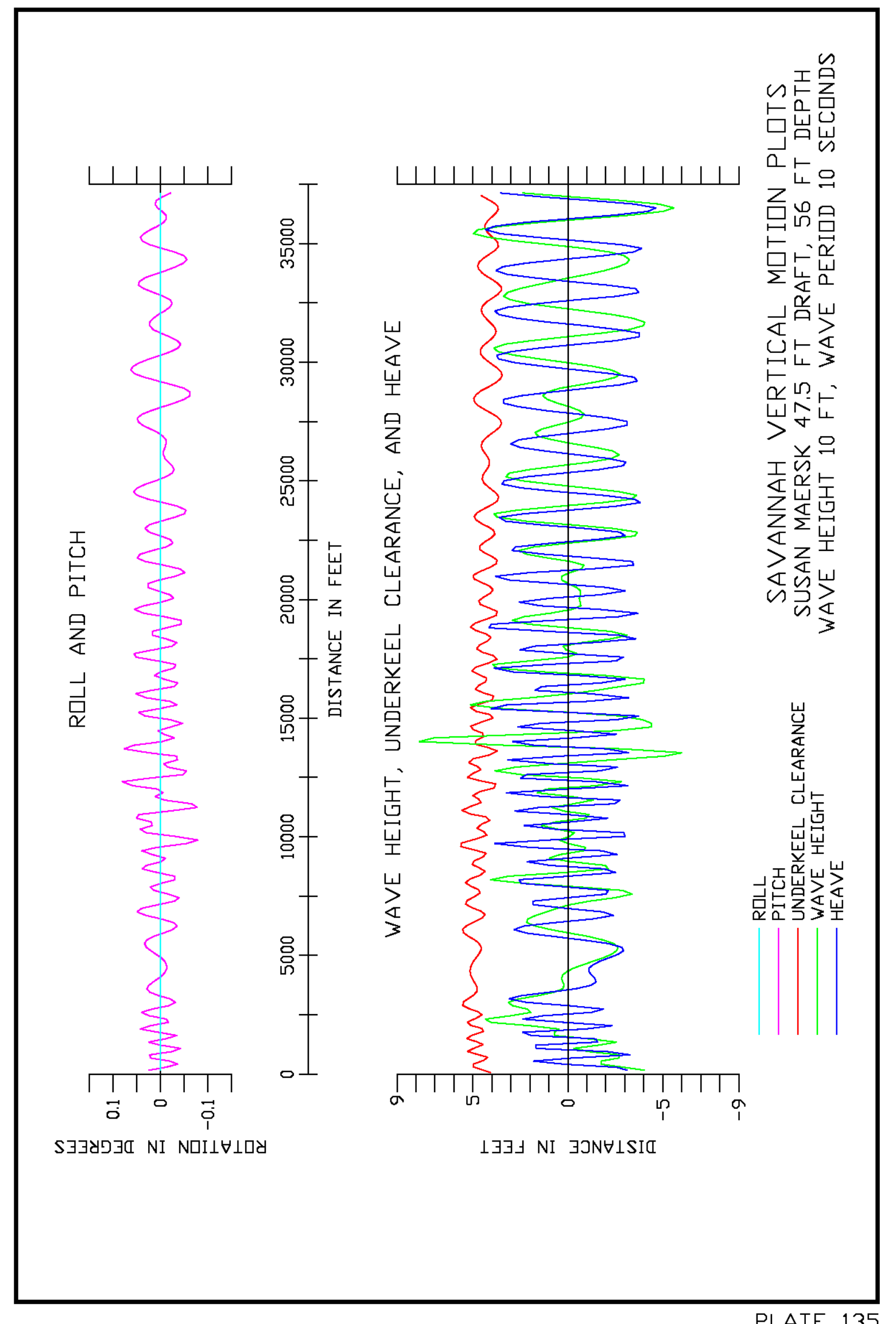




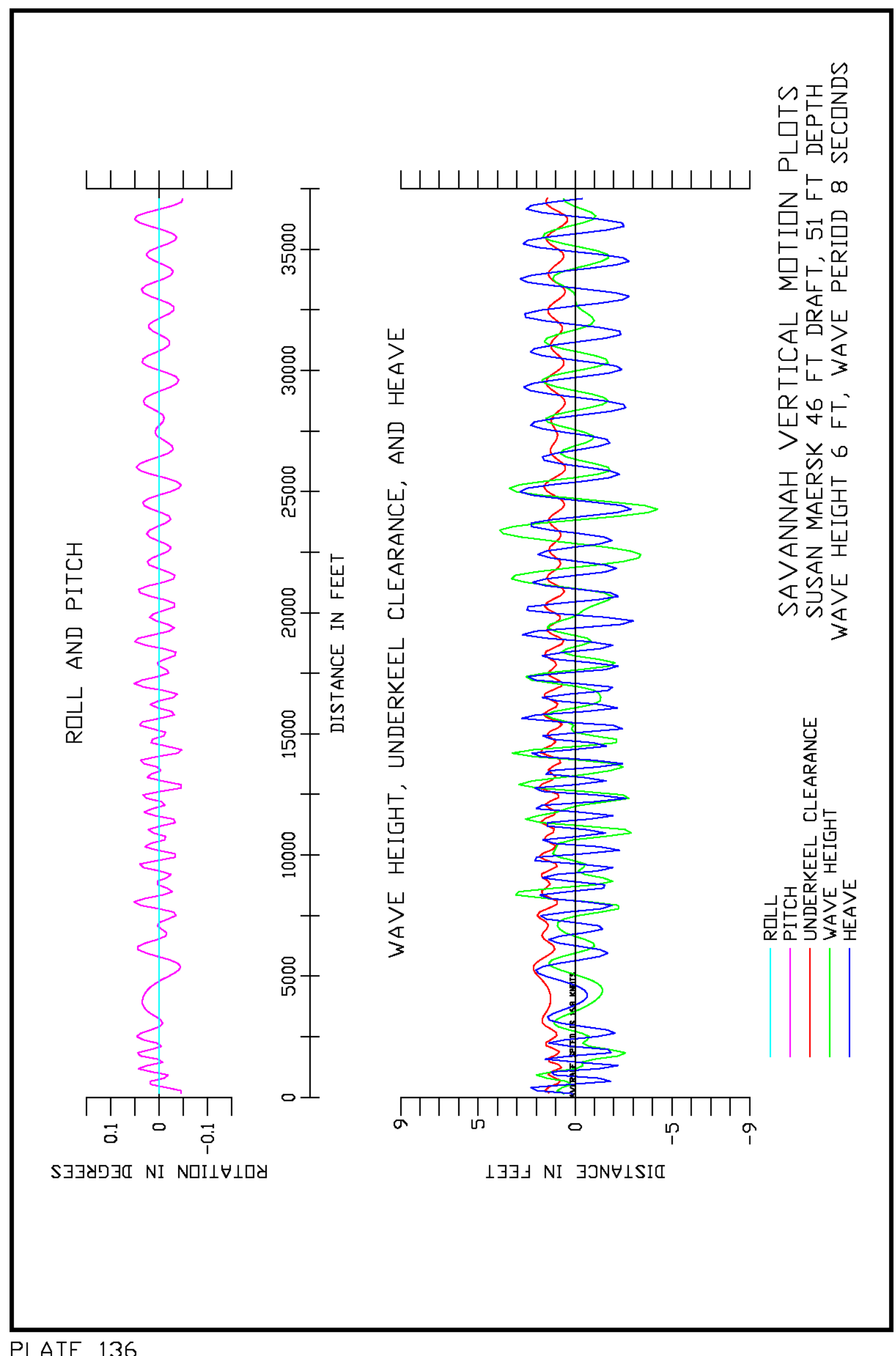

PLATE 136 


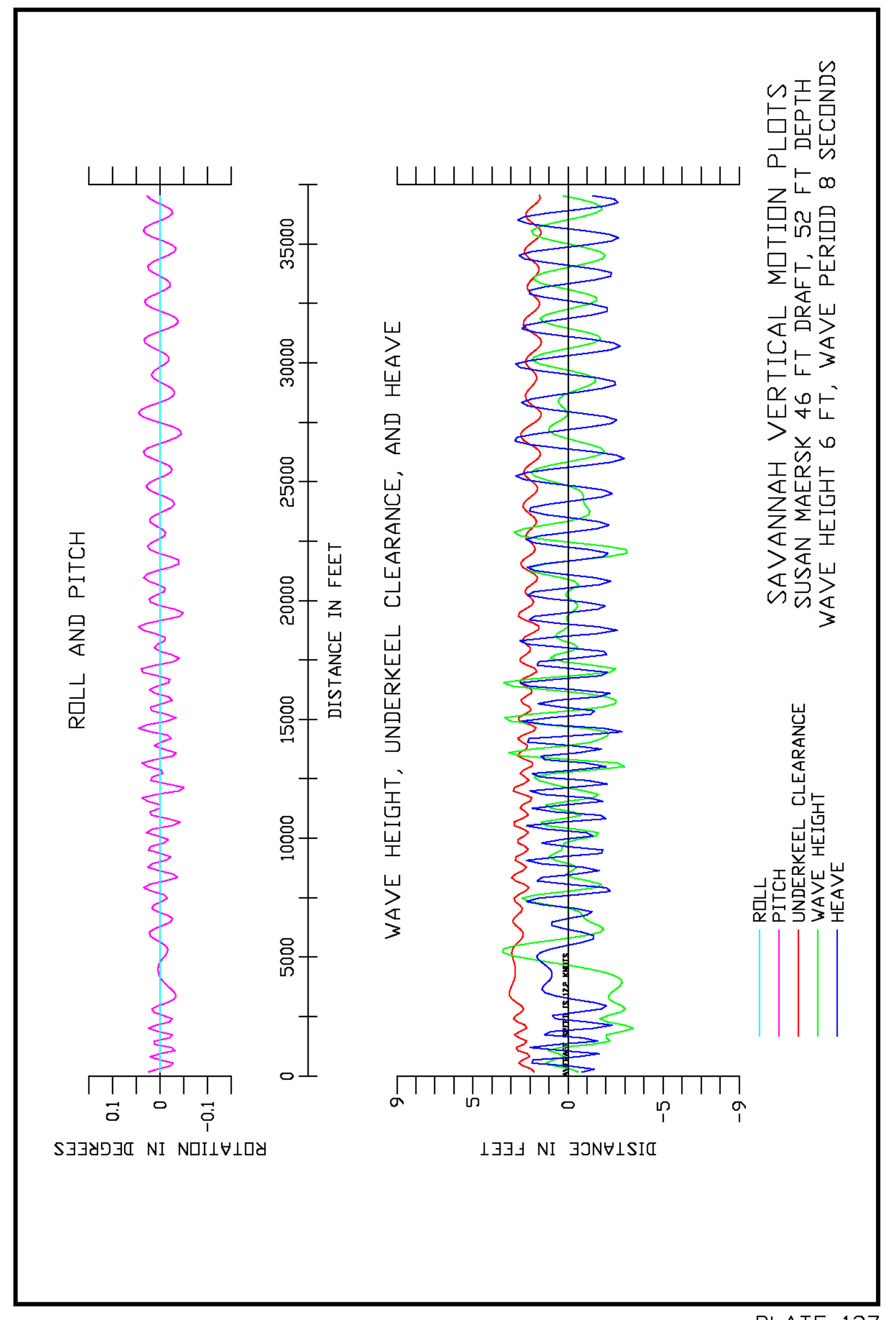




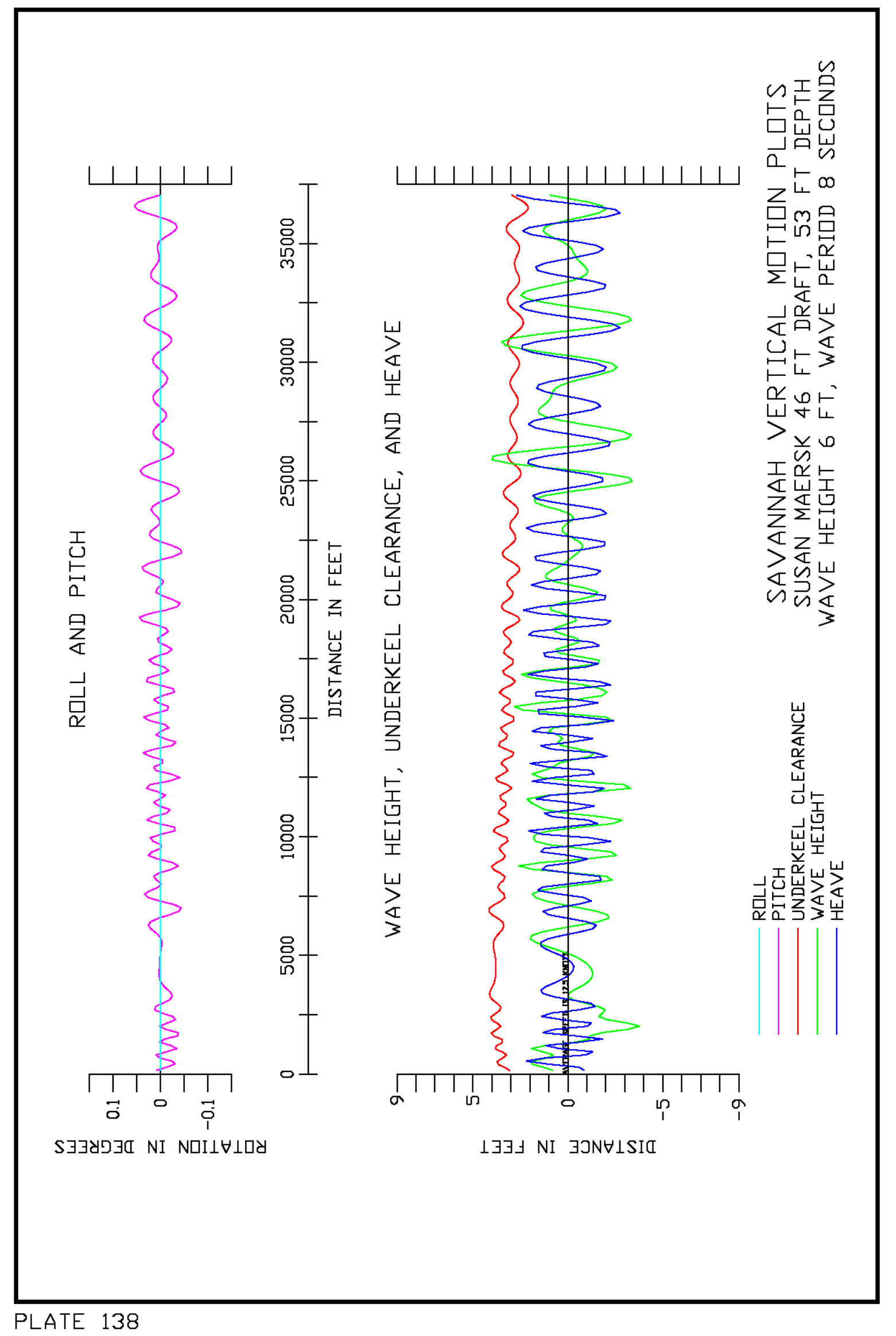




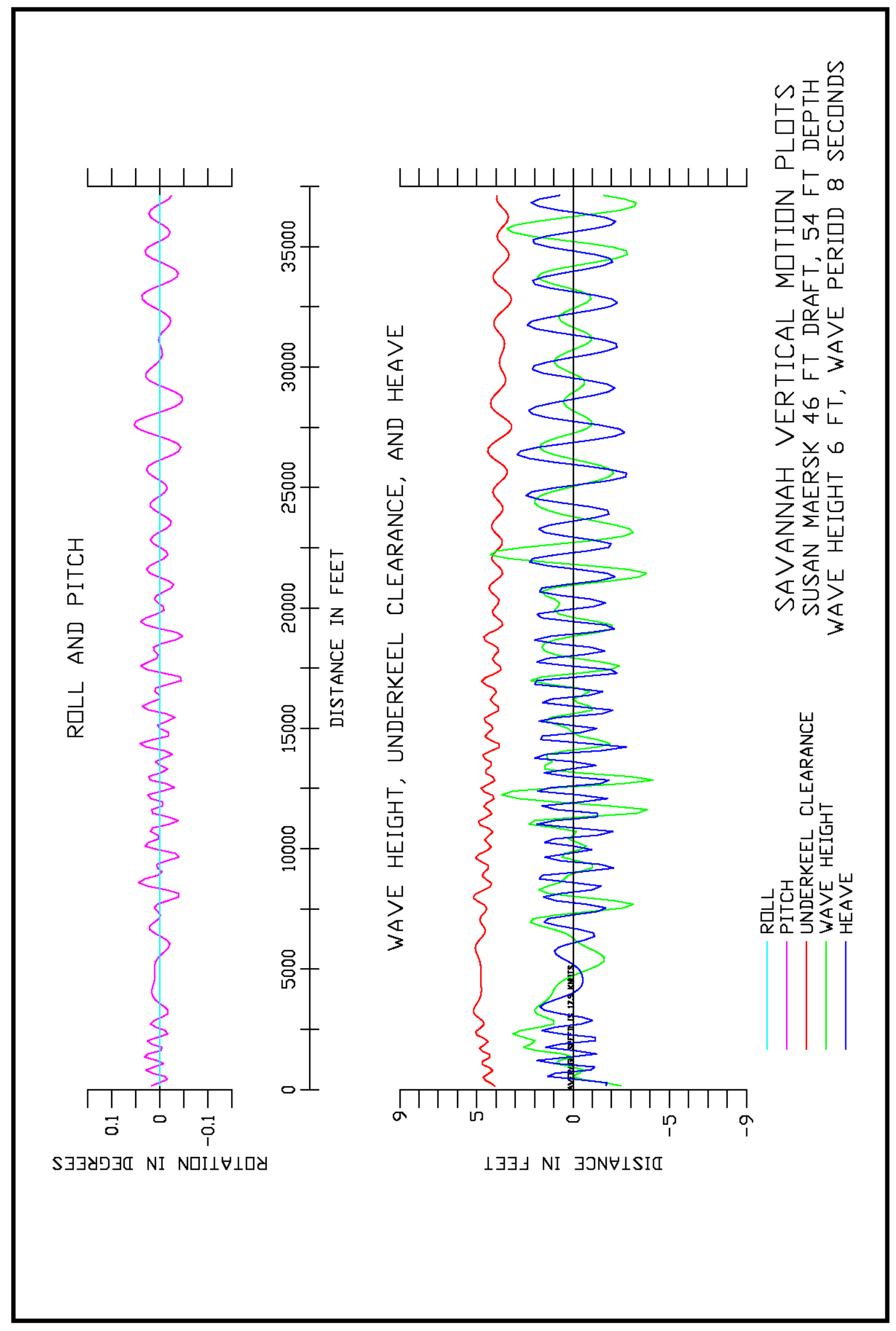

PLATE 139 


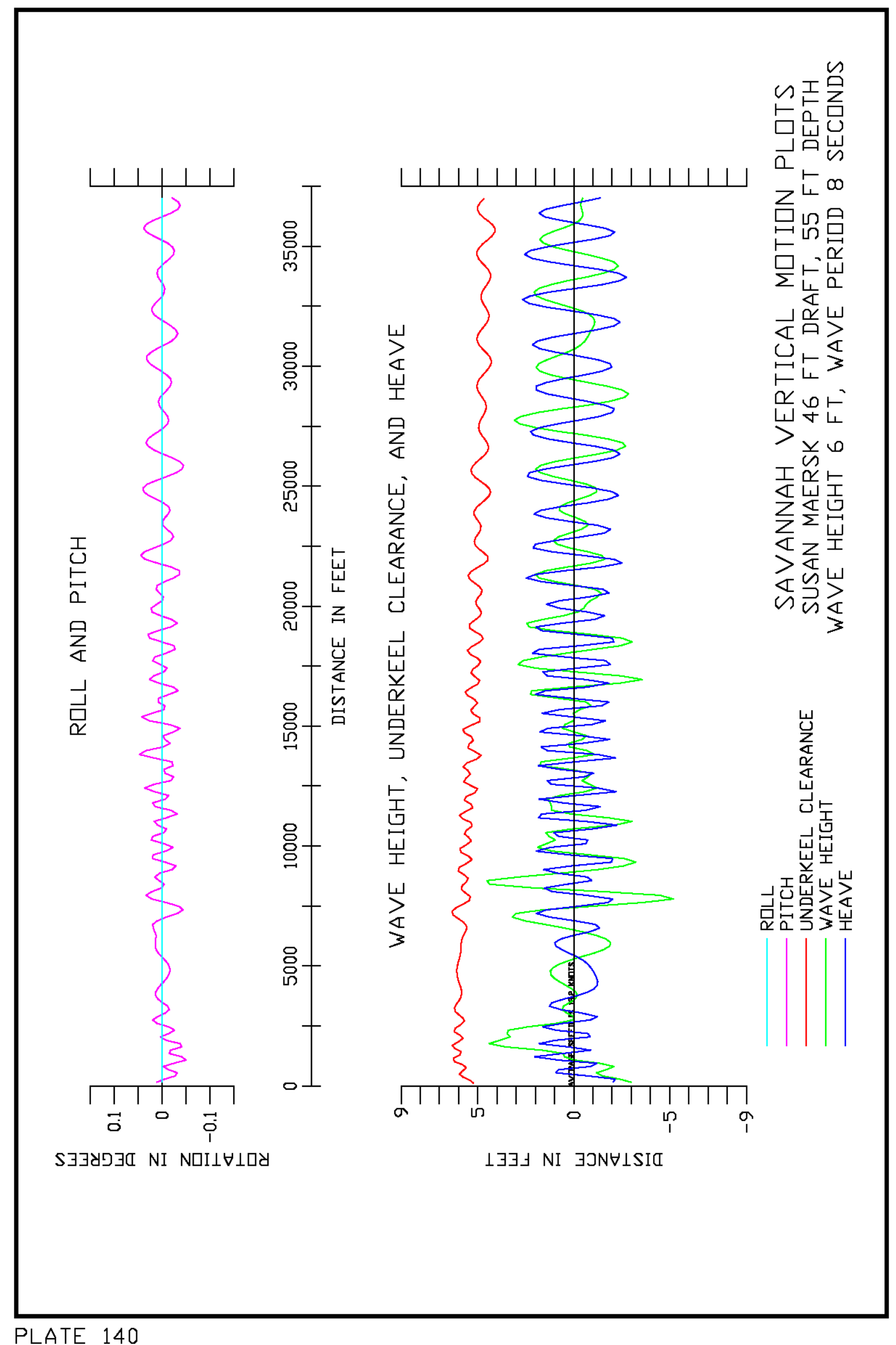

PLATE 140 


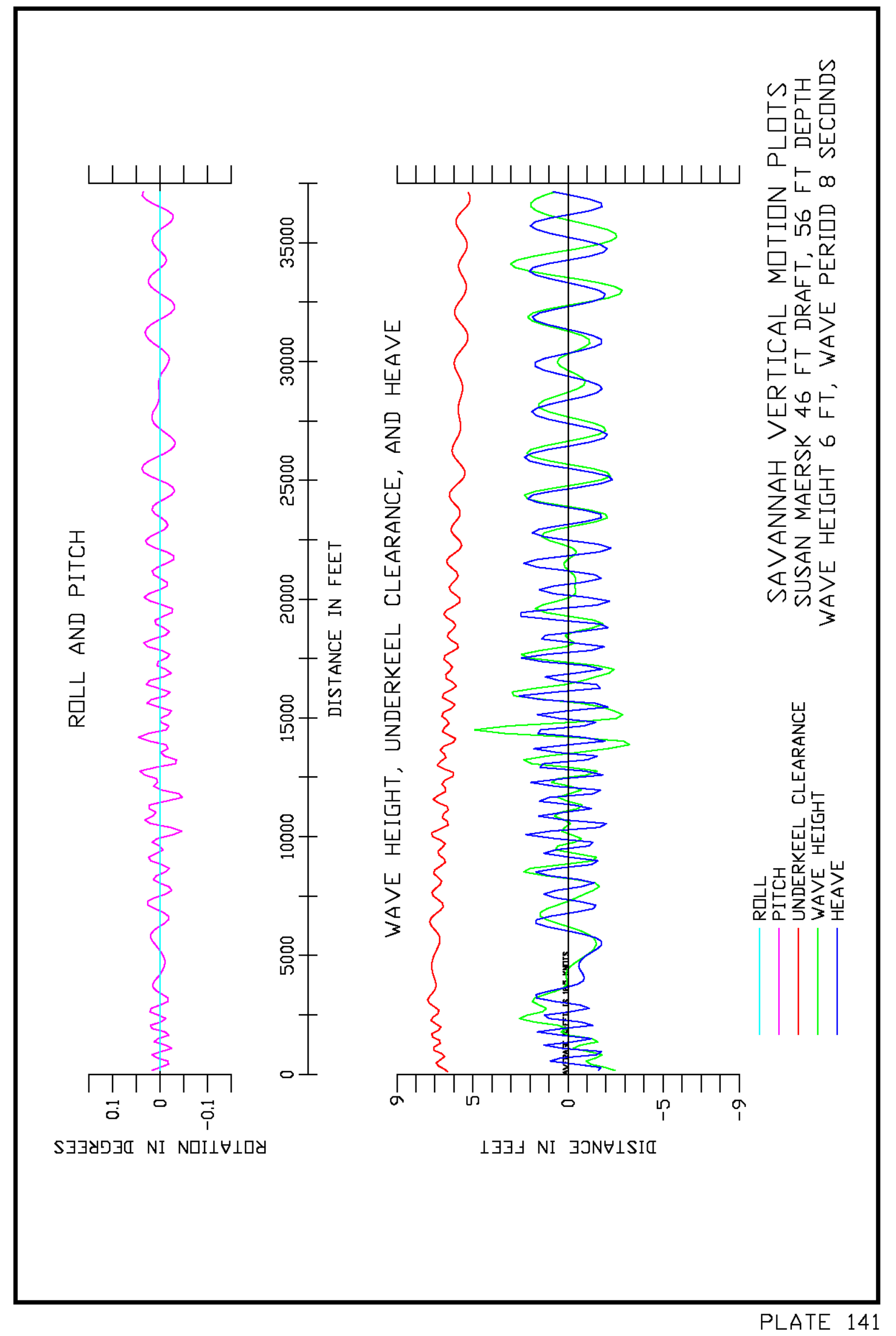




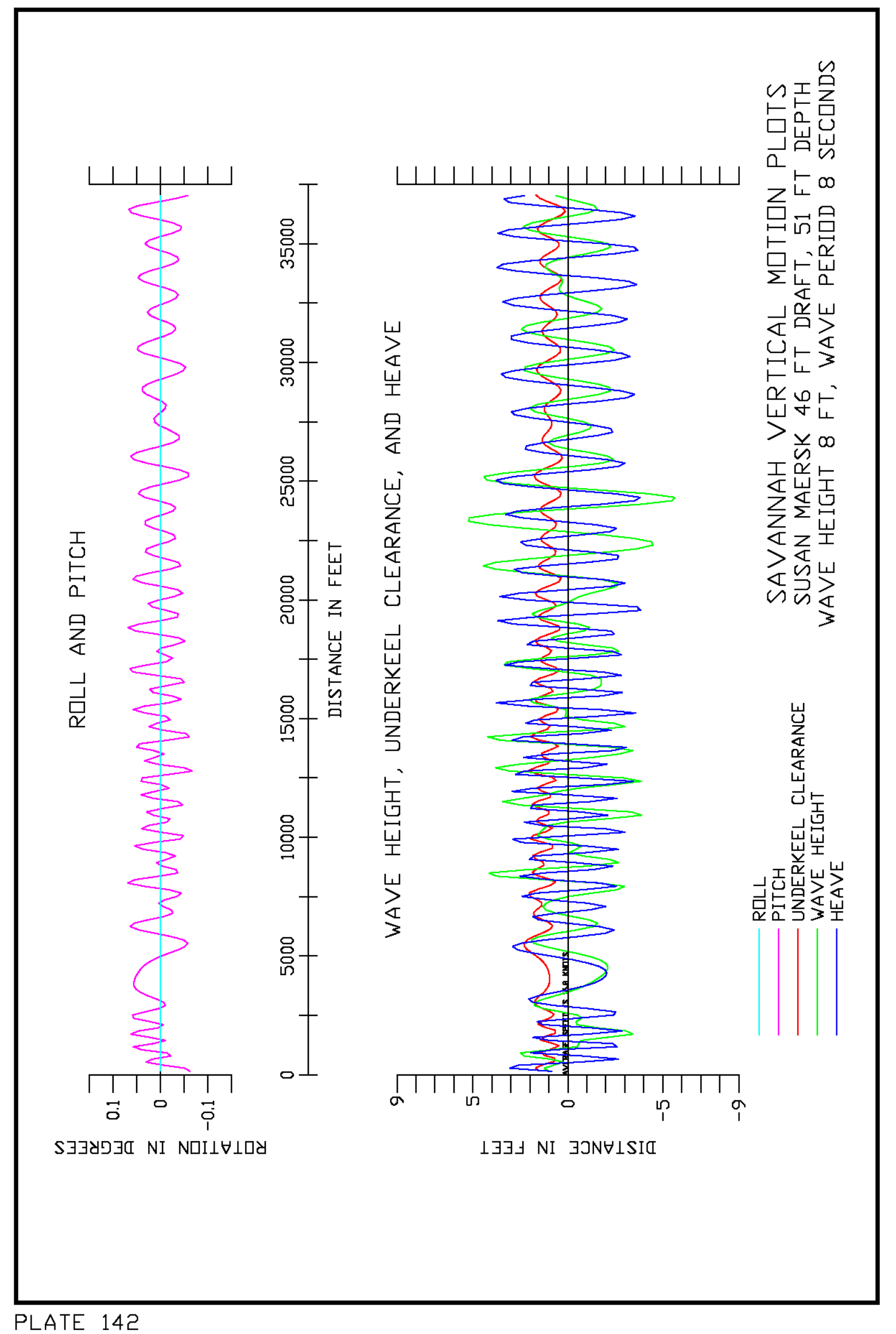




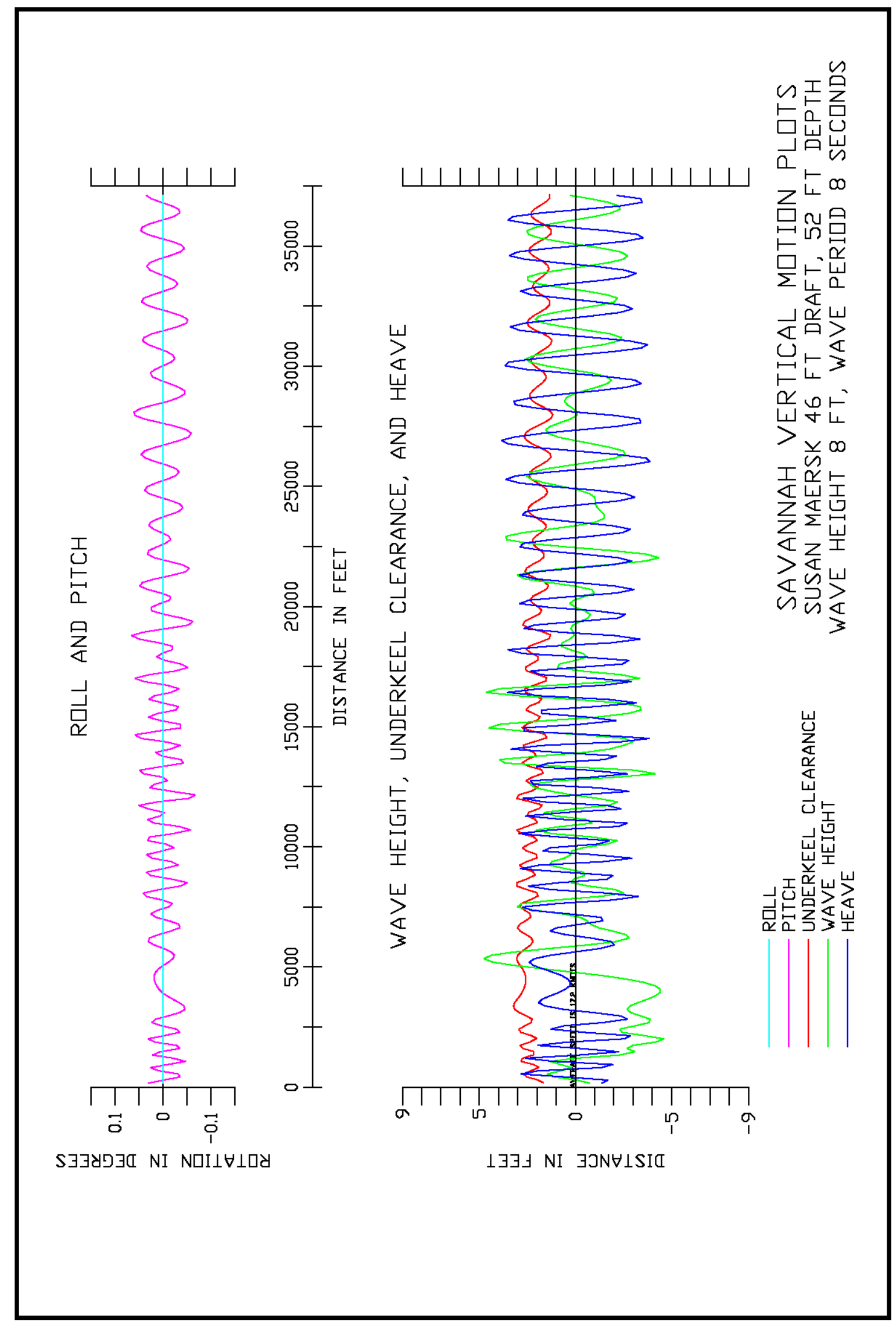




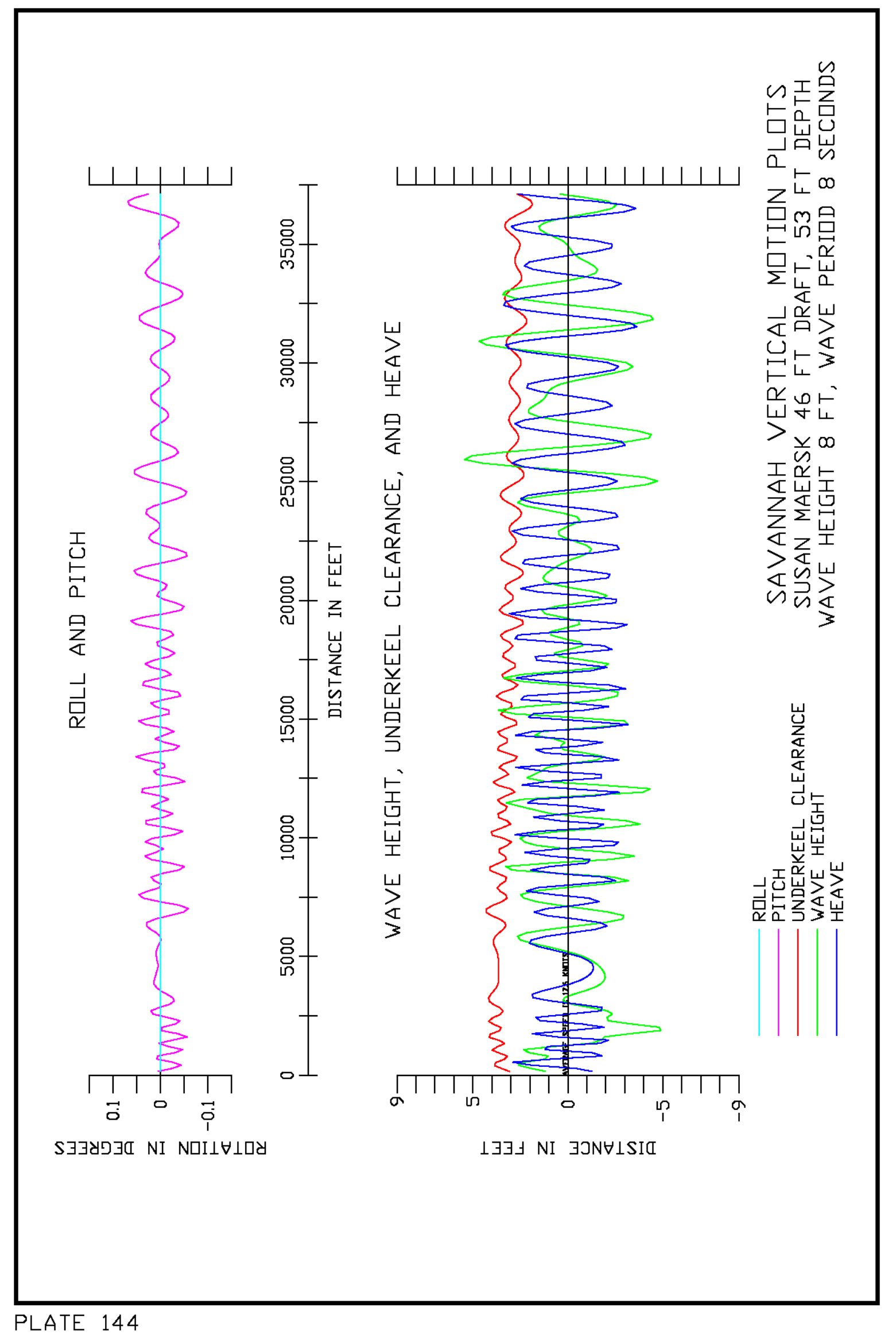




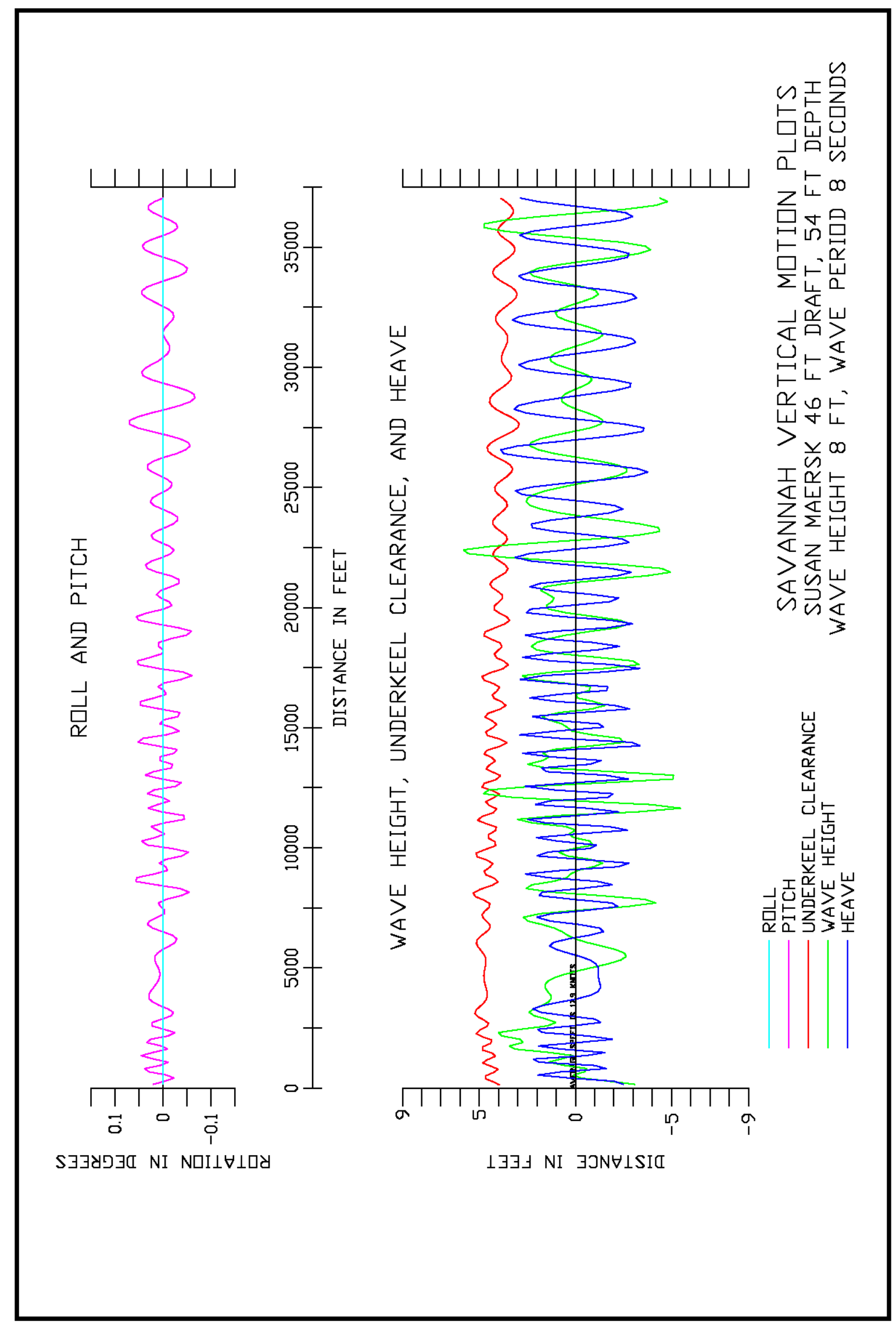




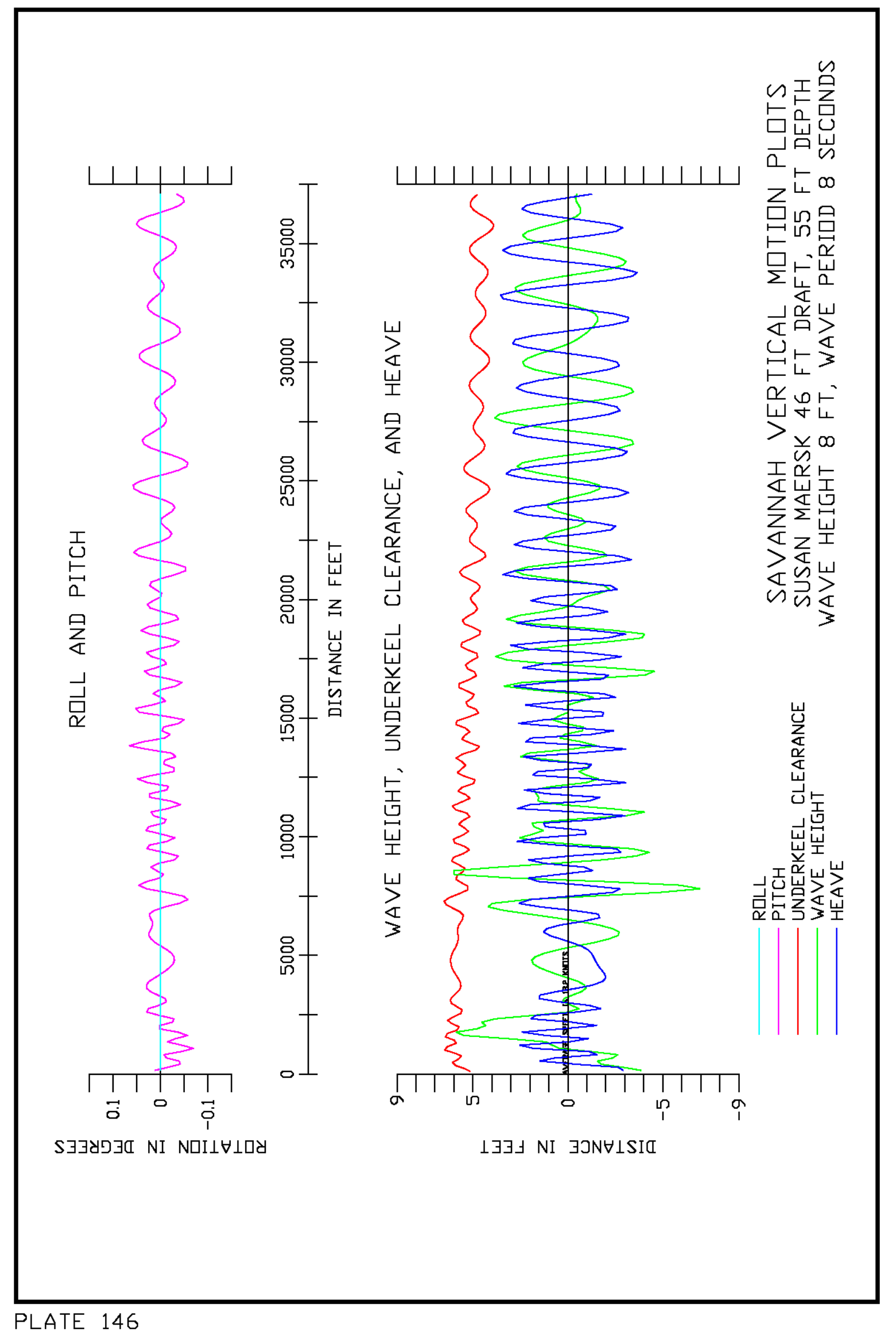




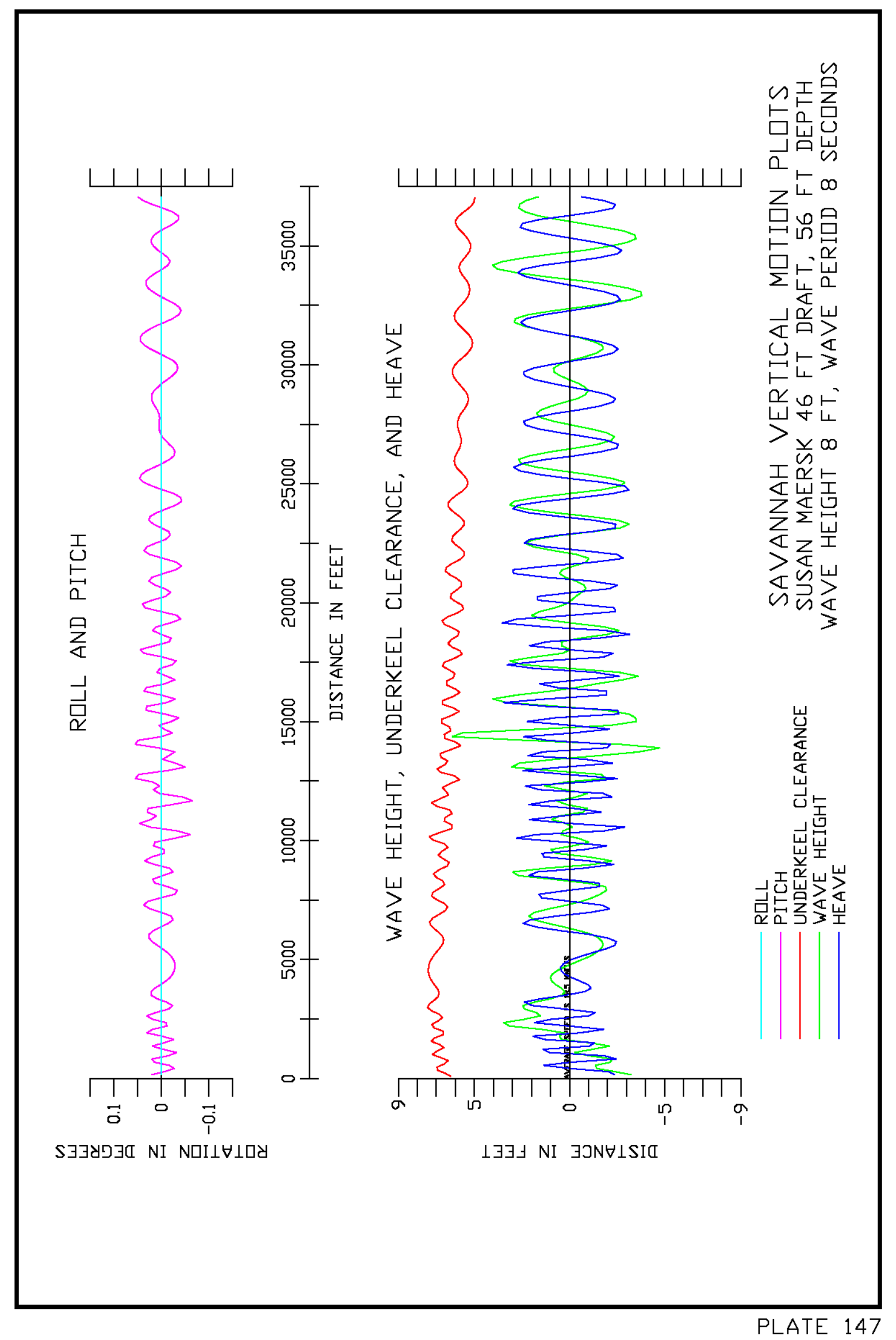




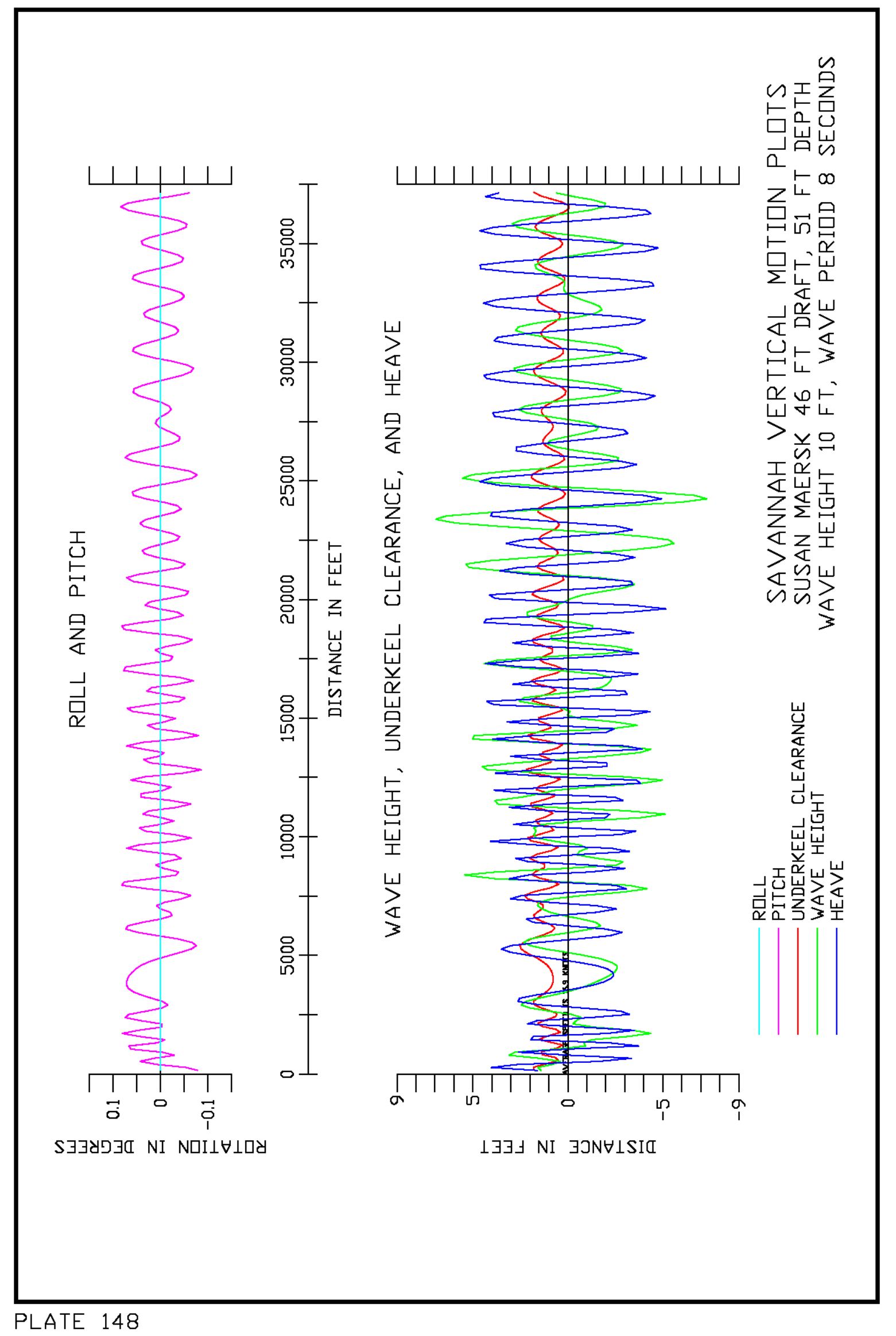




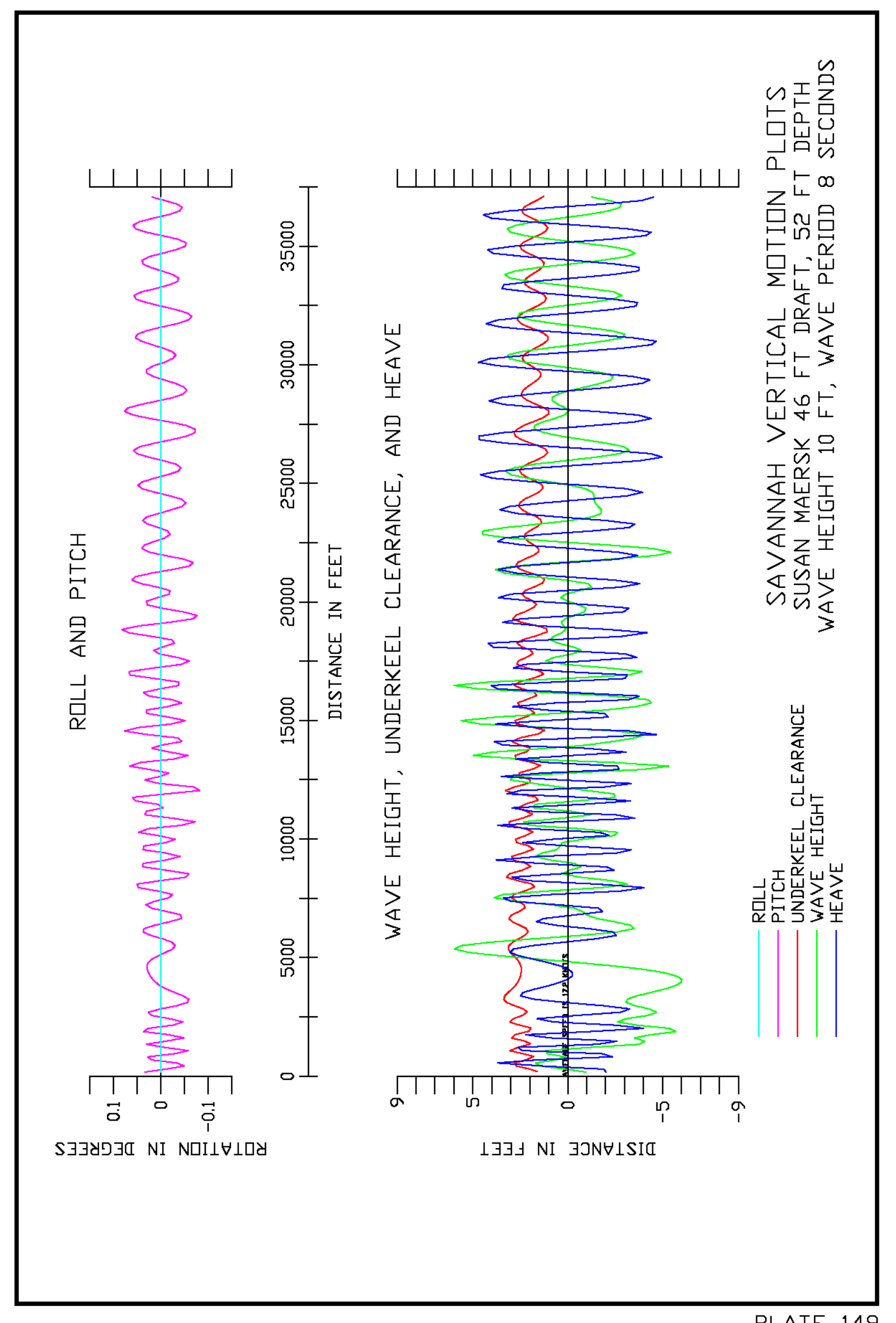




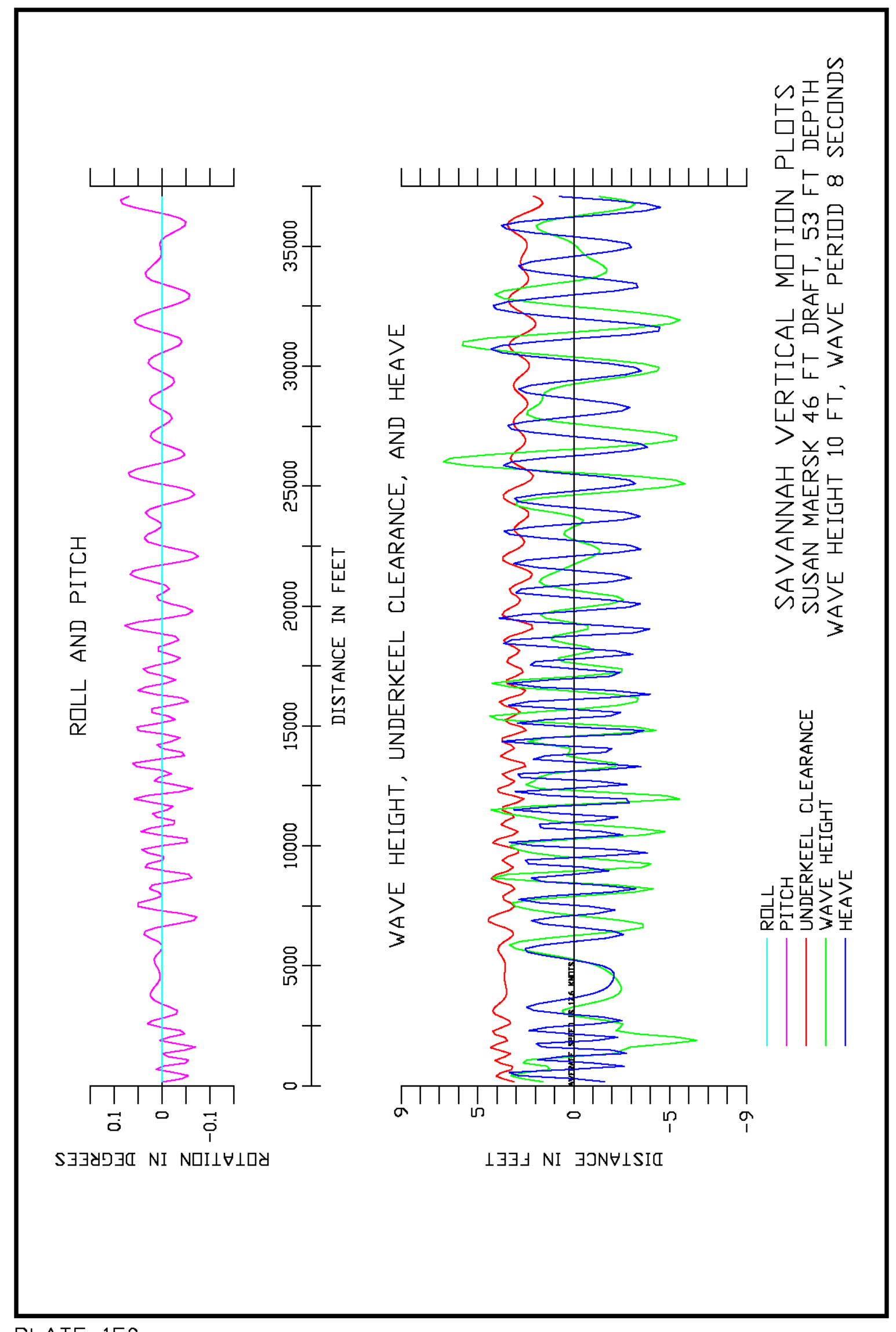

PLATE 150 


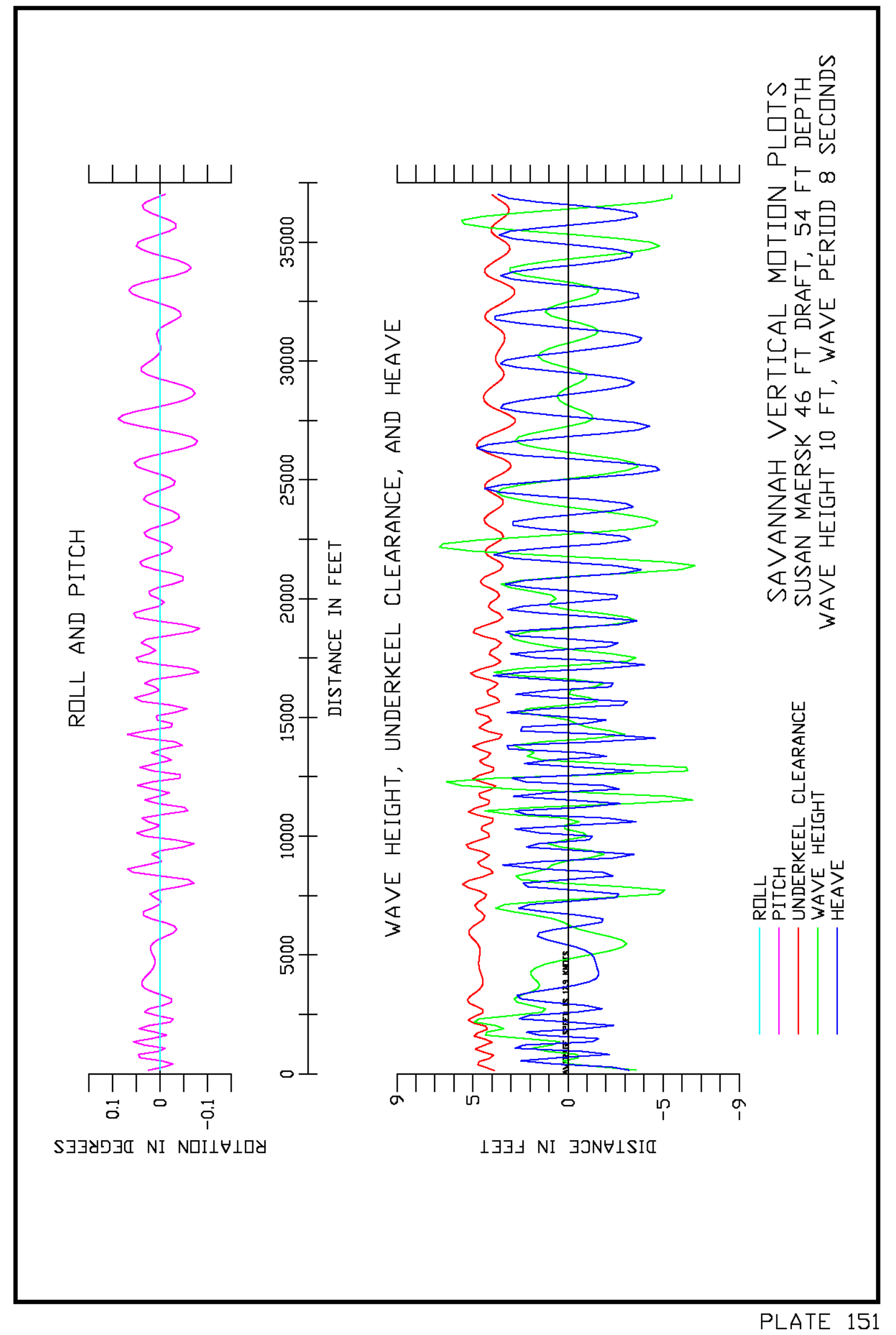




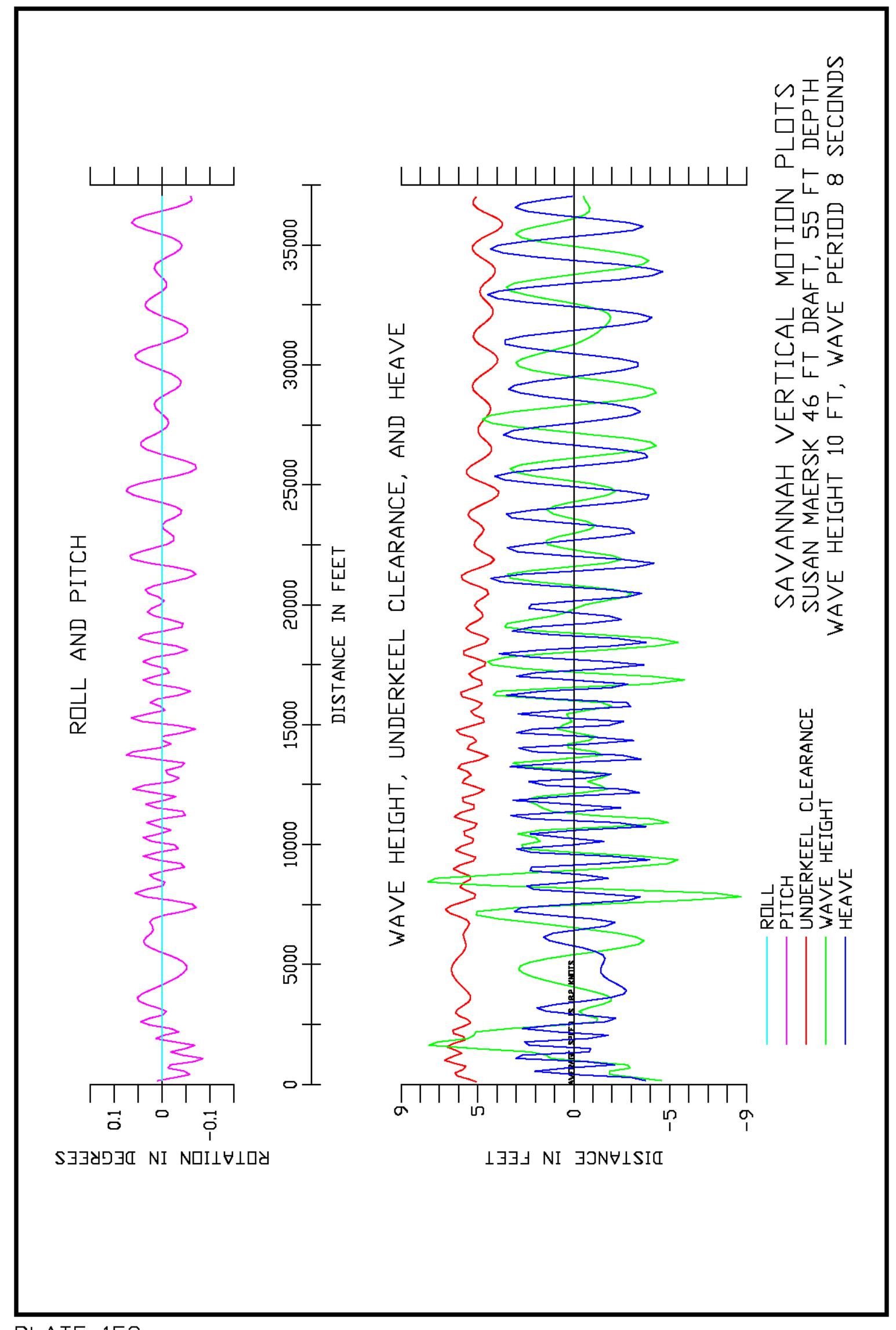

PLATE 152 


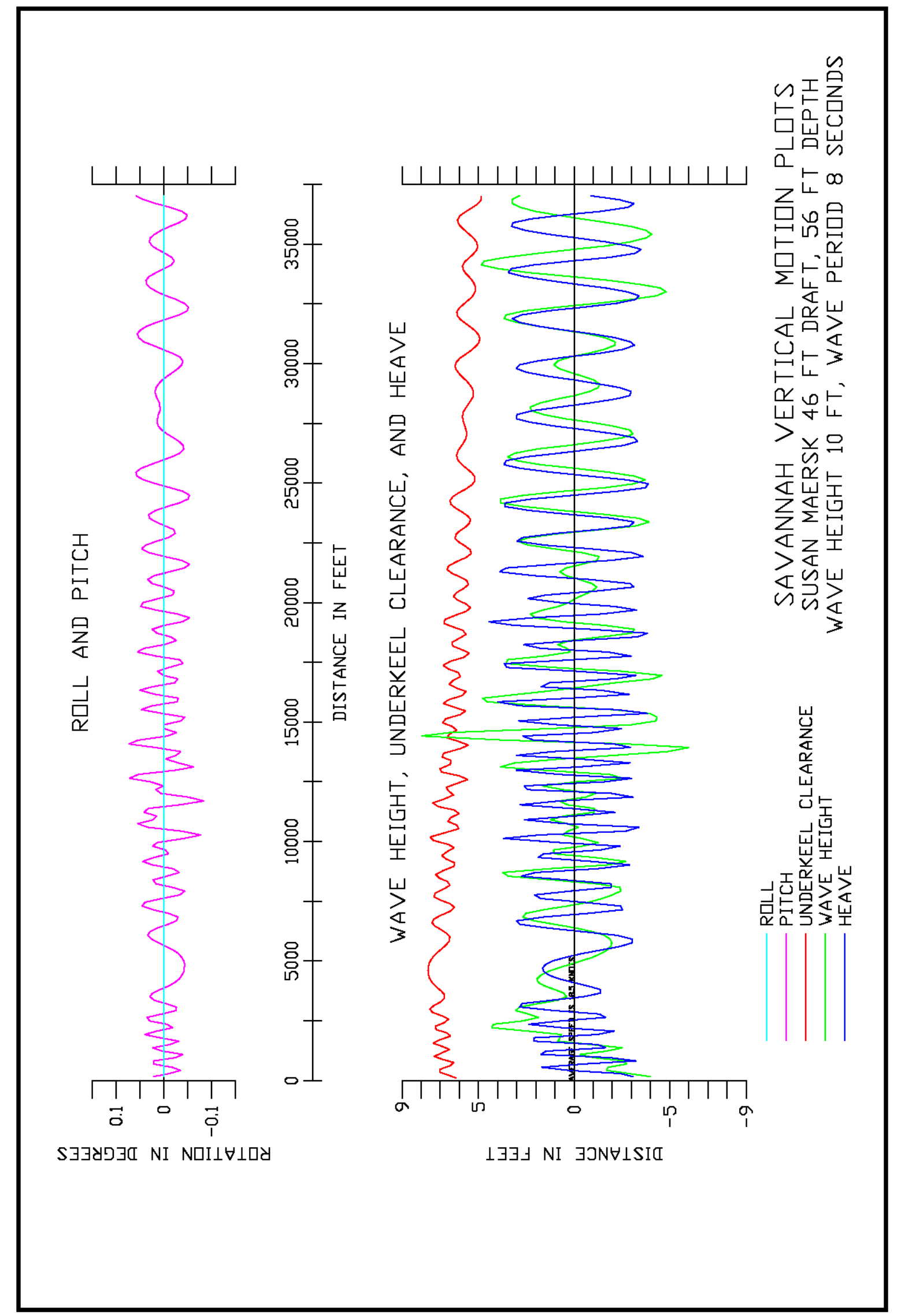




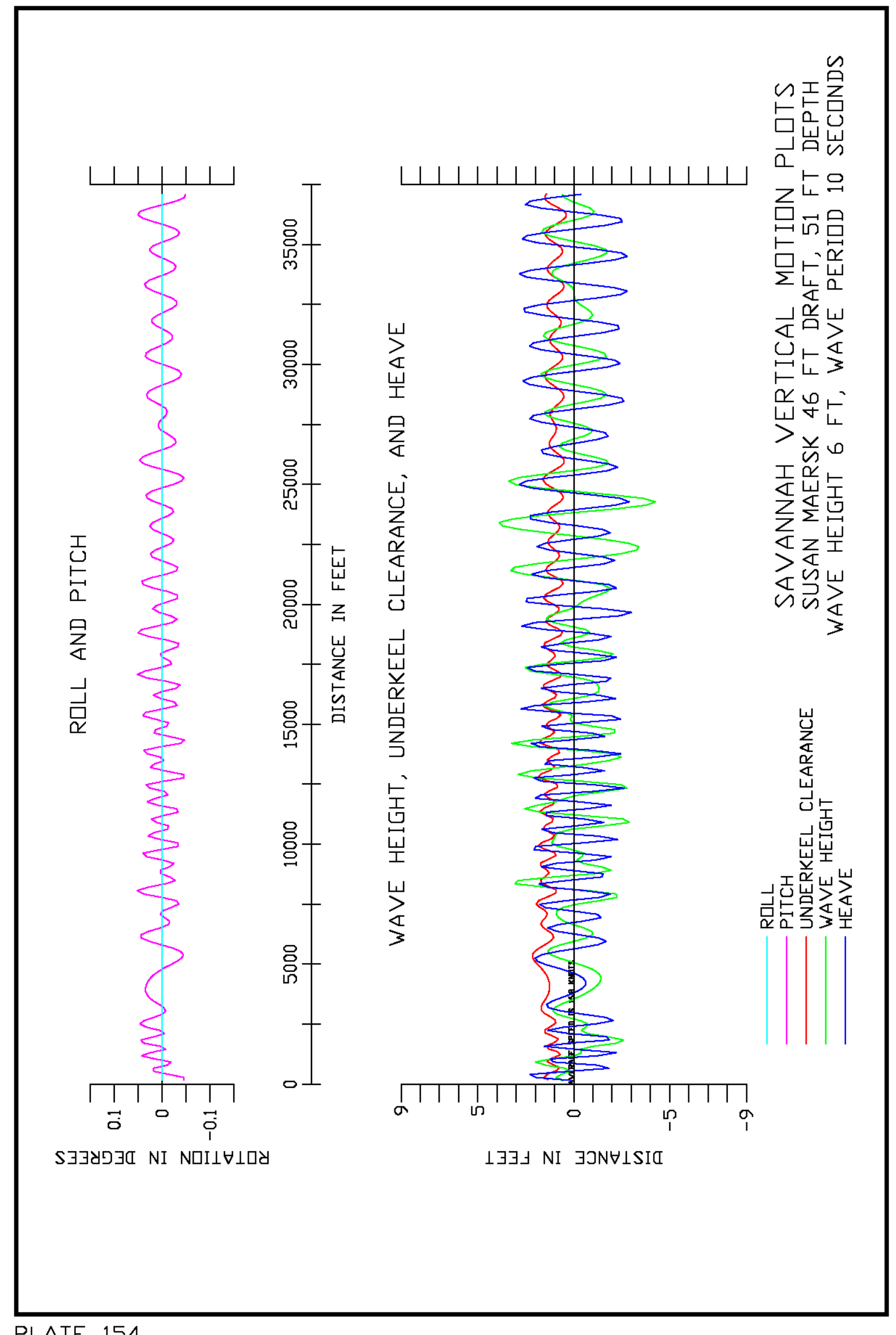

PLATE 154 


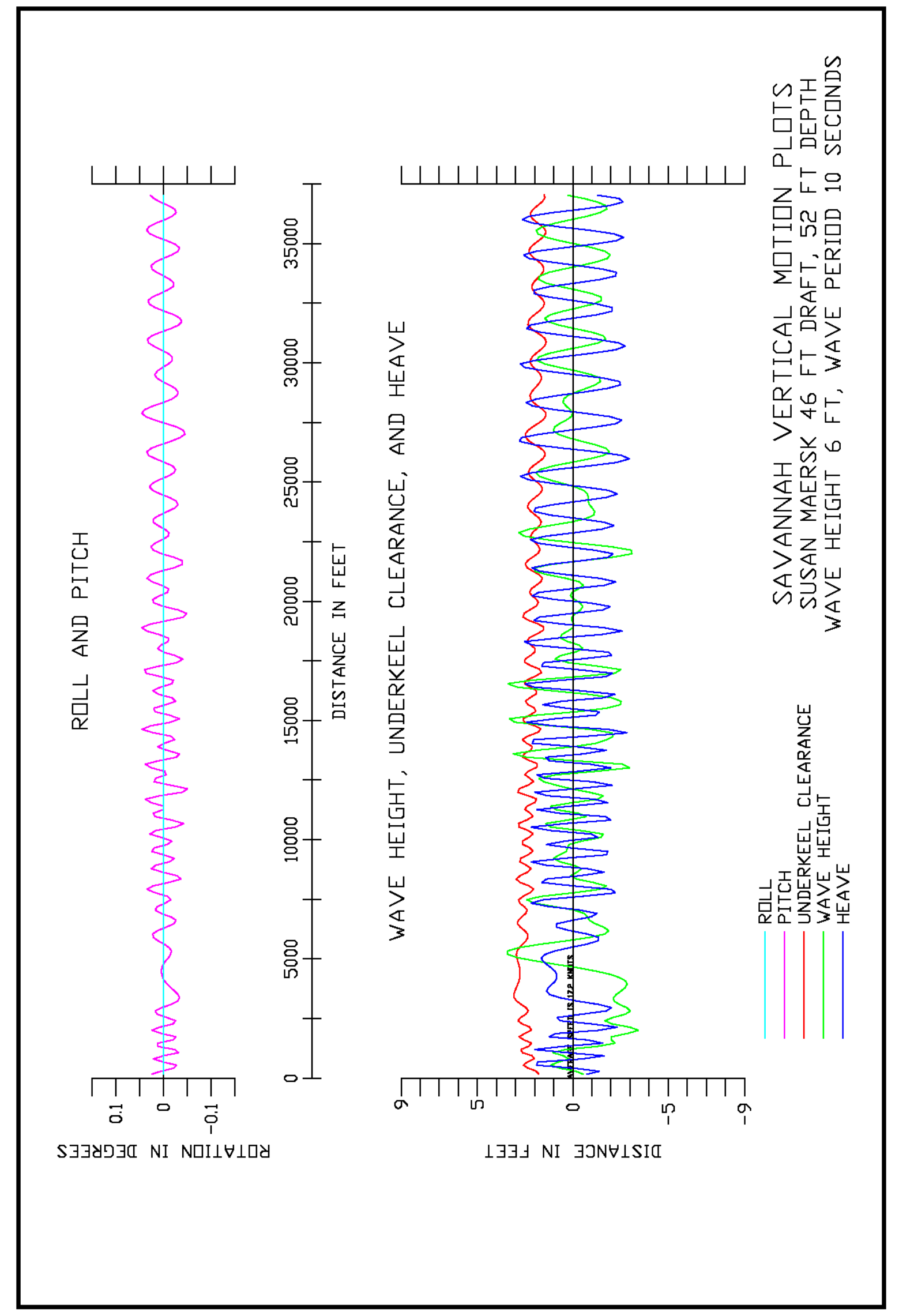




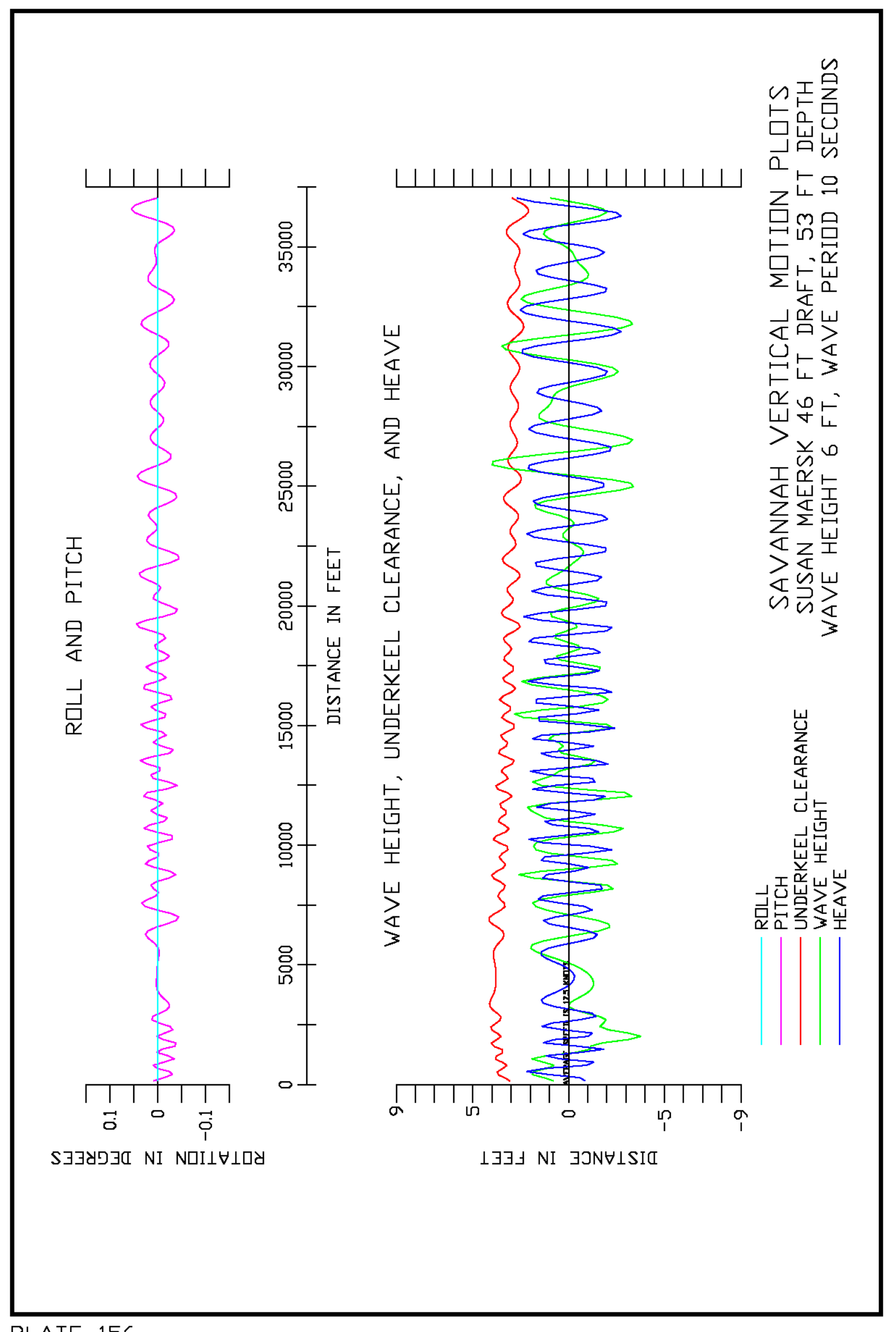

PLATE 156 


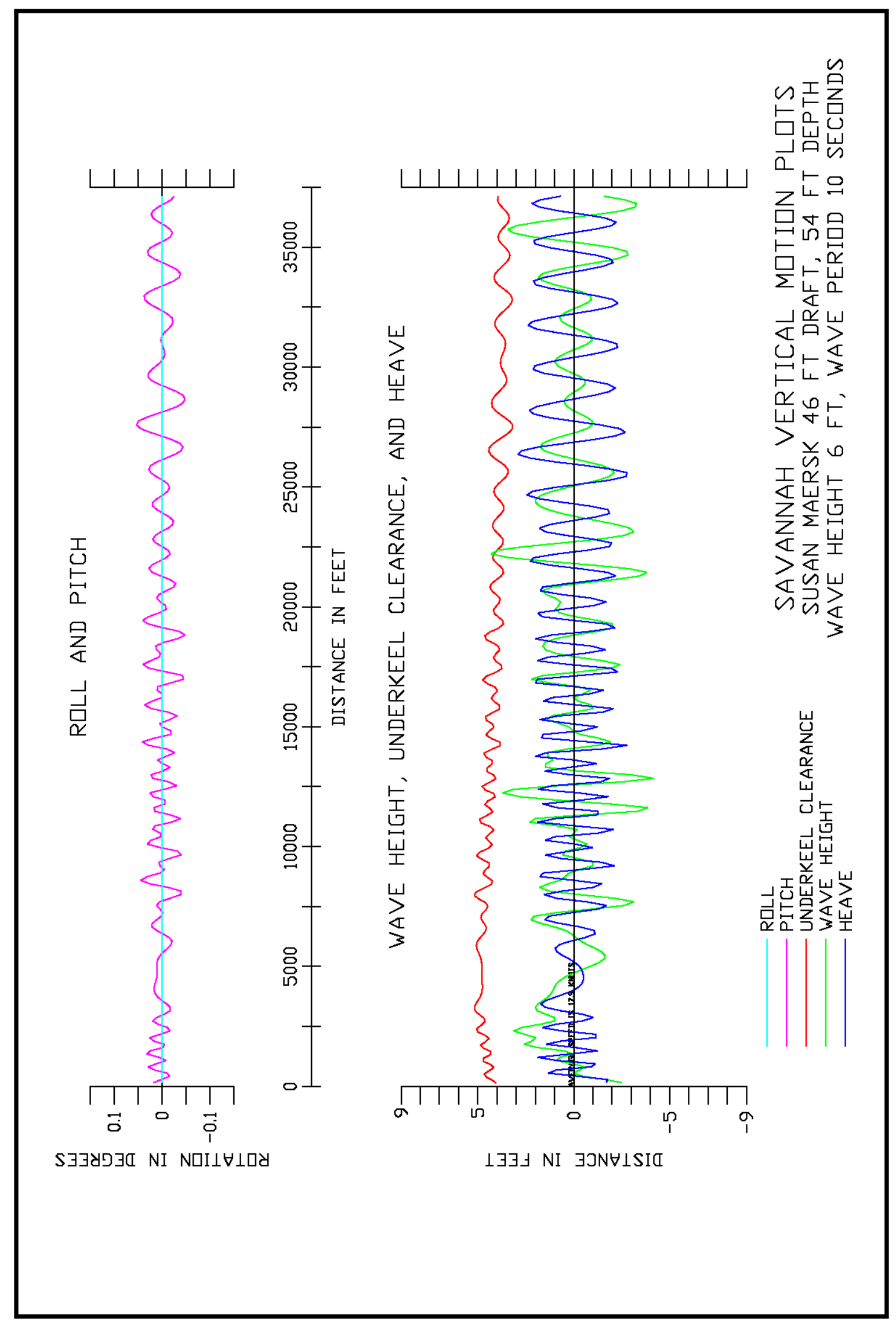




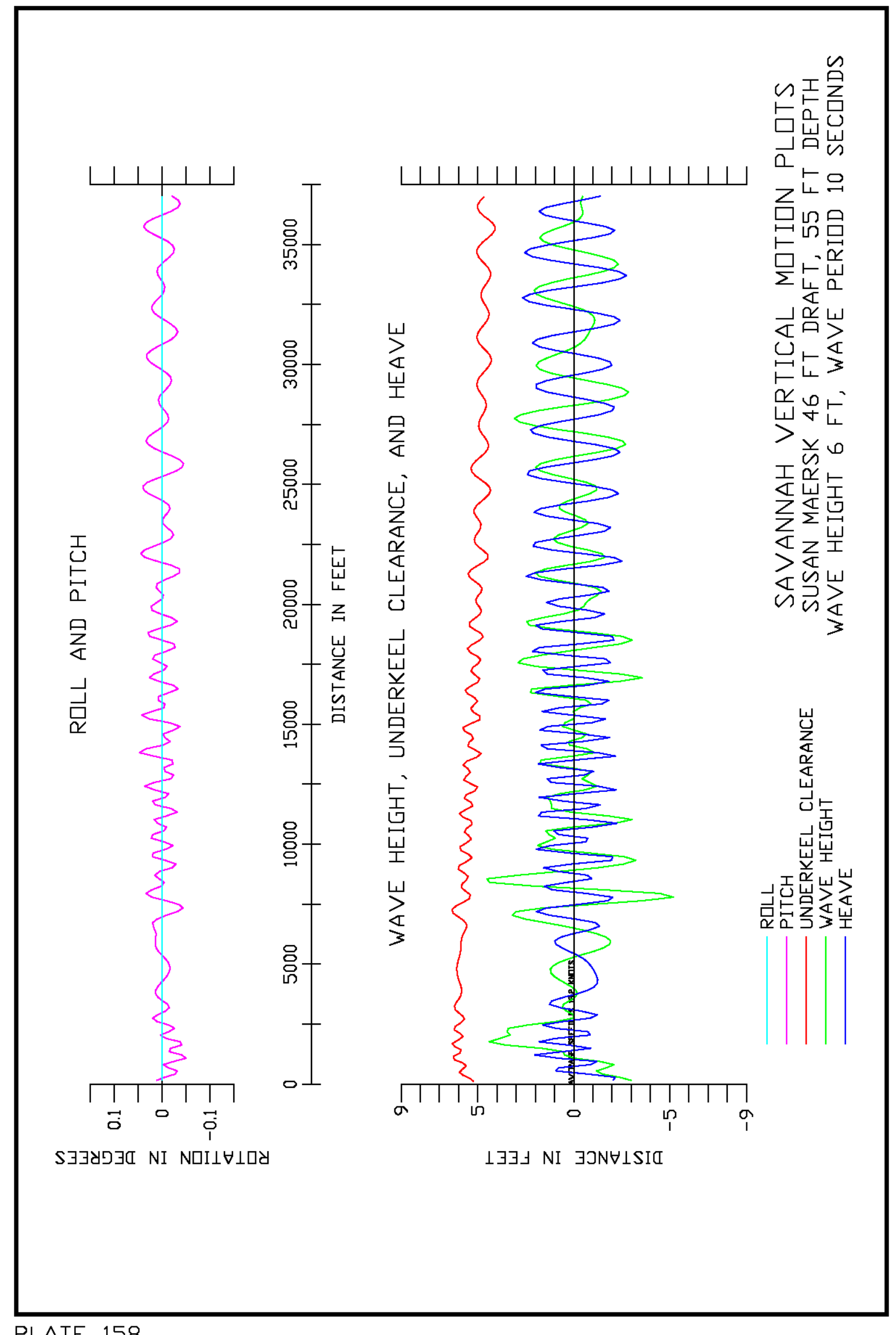

PLATE 158 


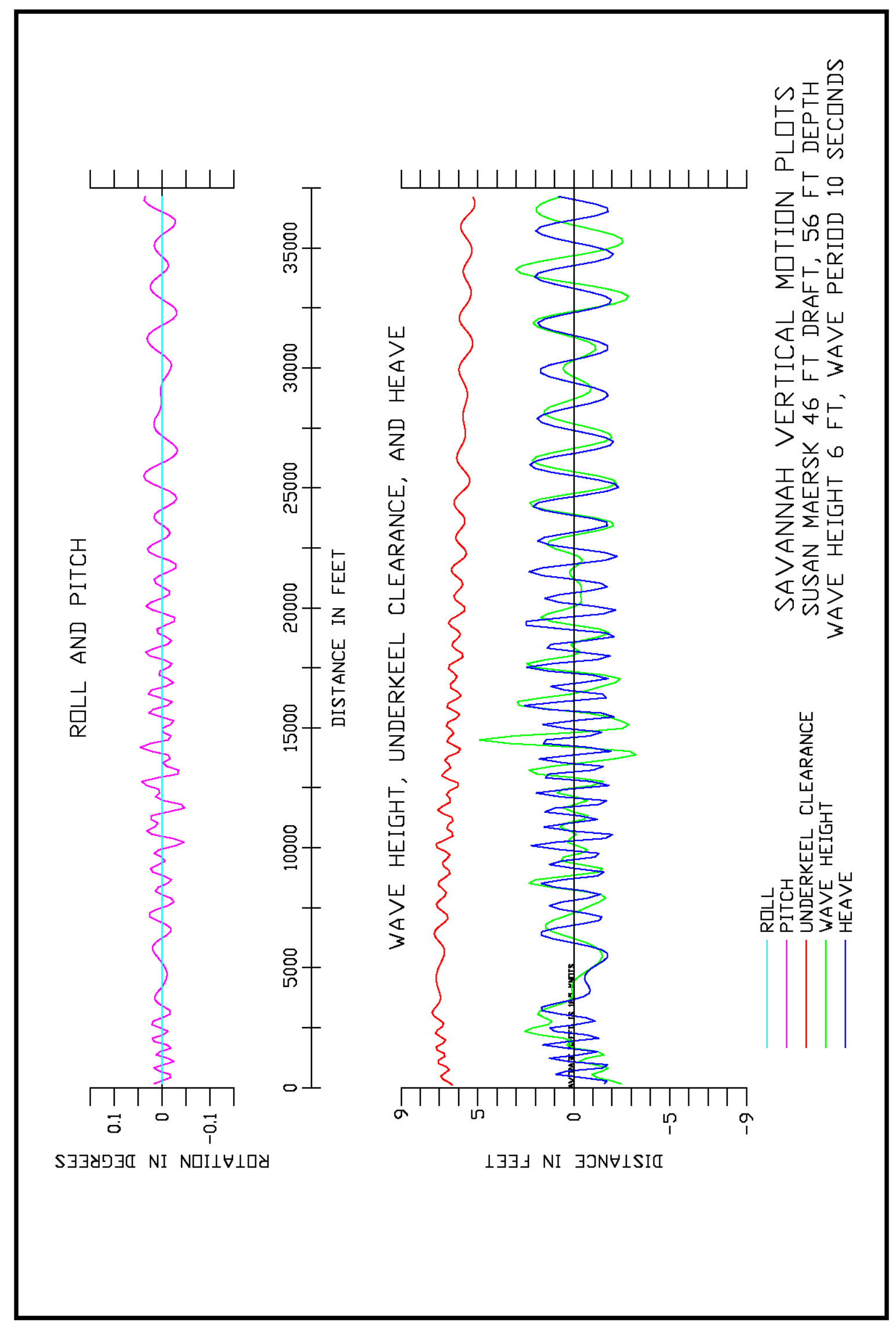




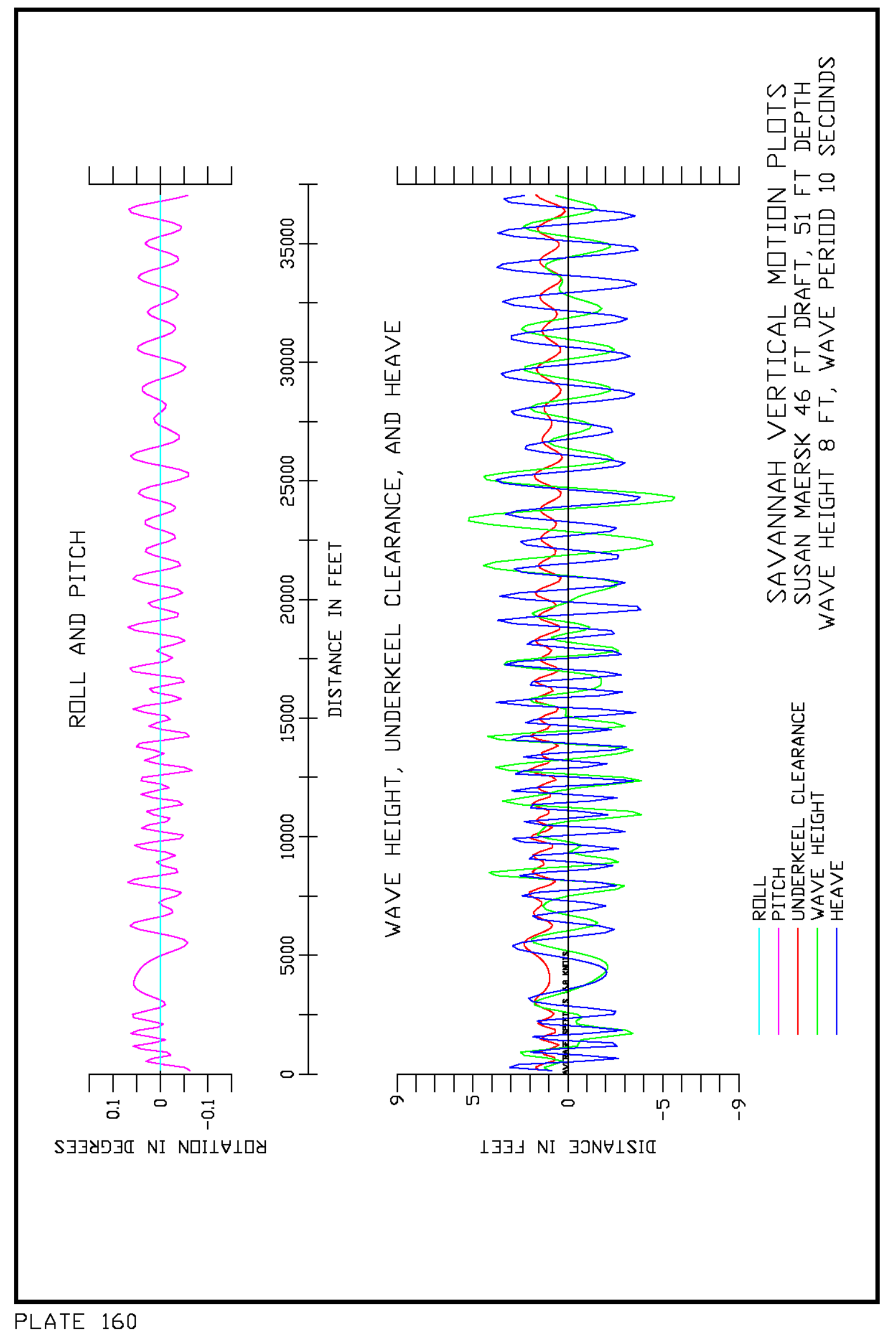




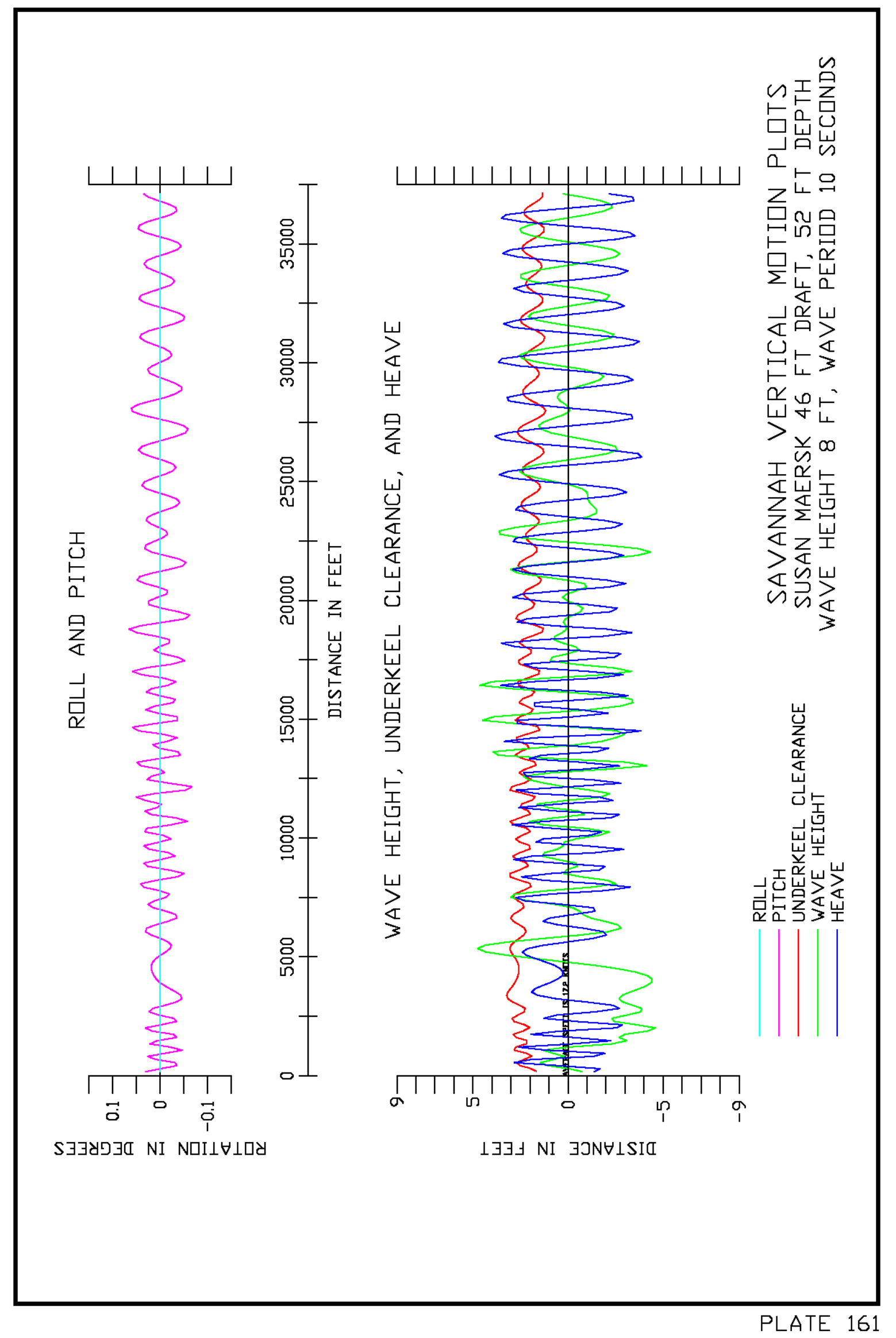




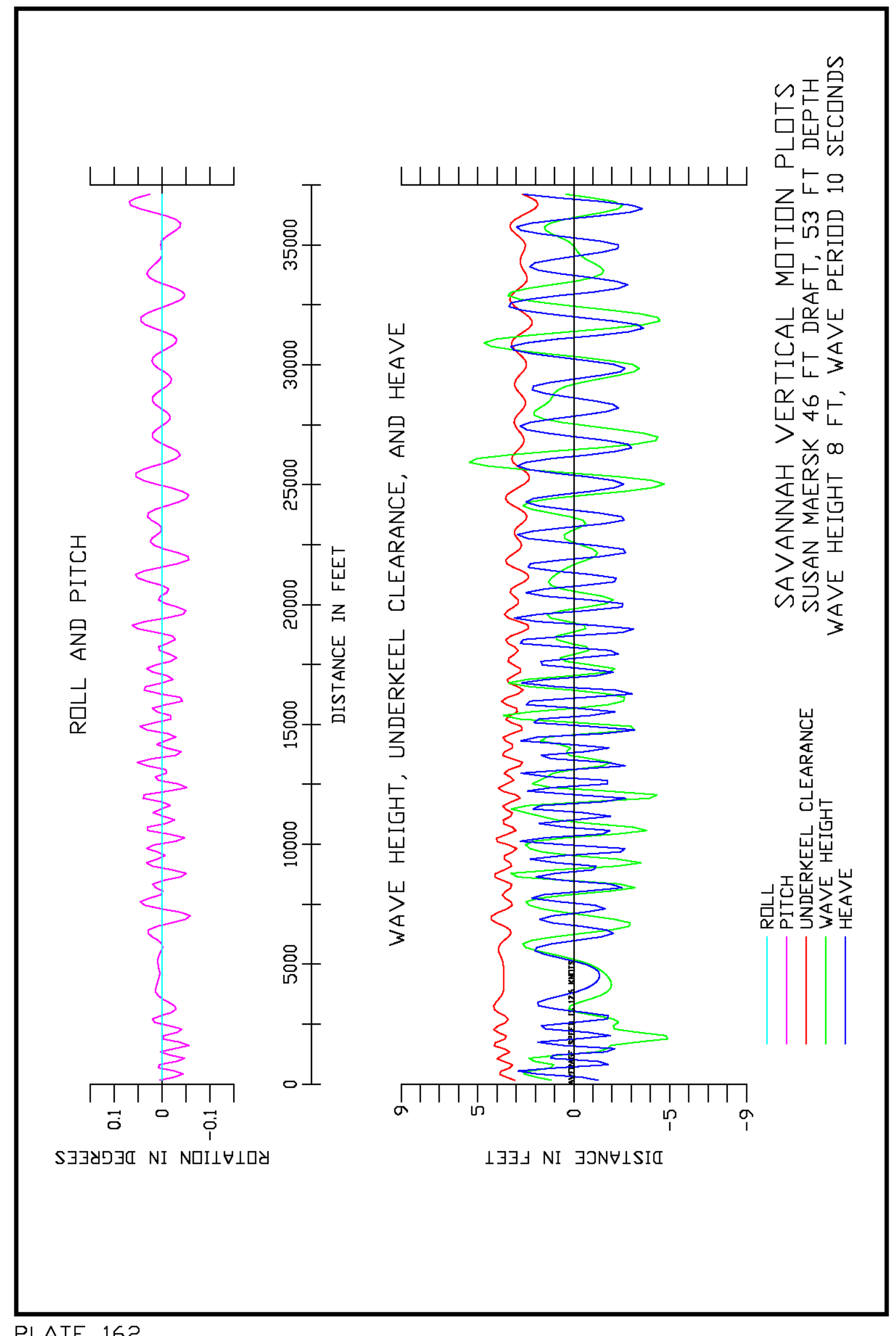

PLATE 162 


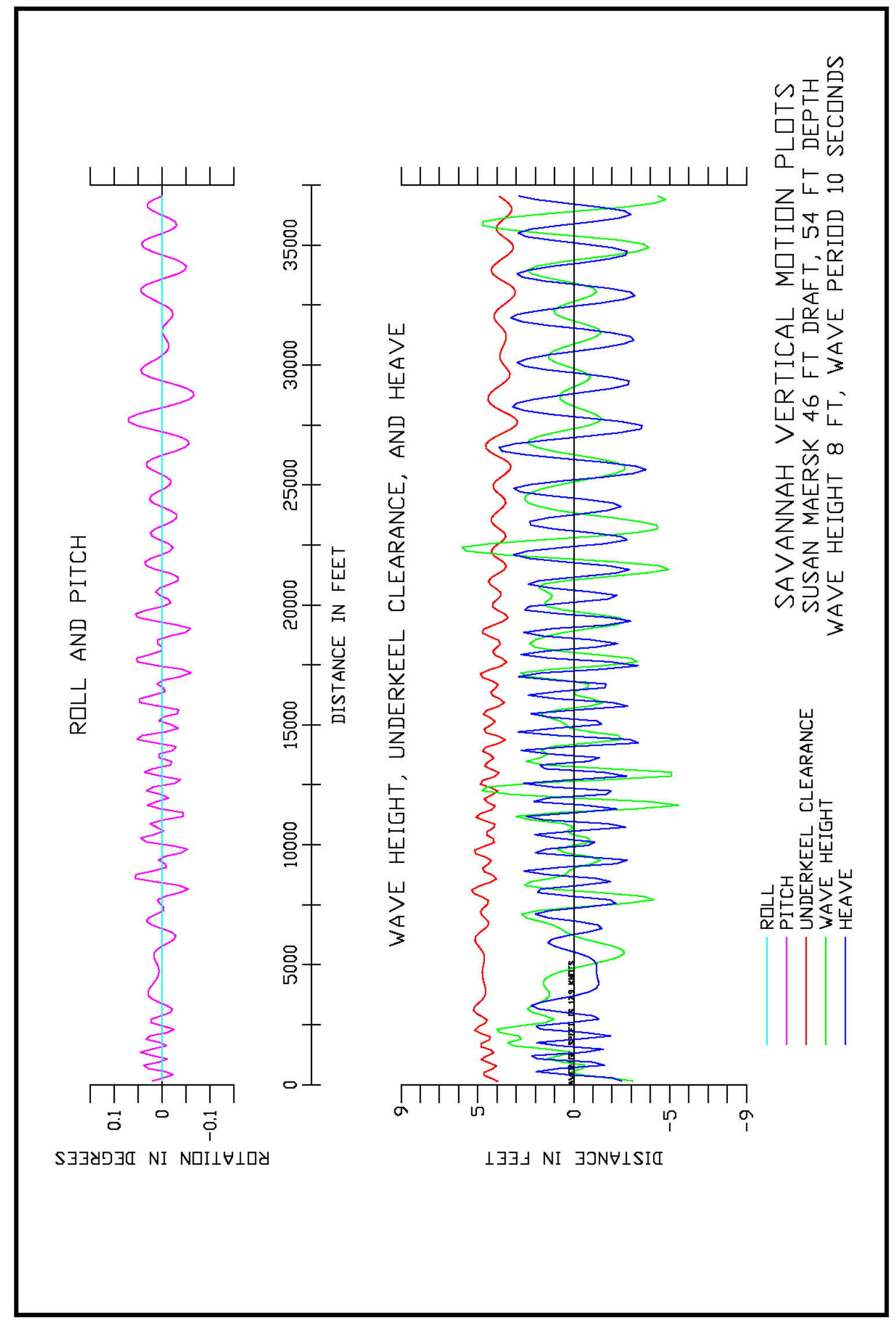




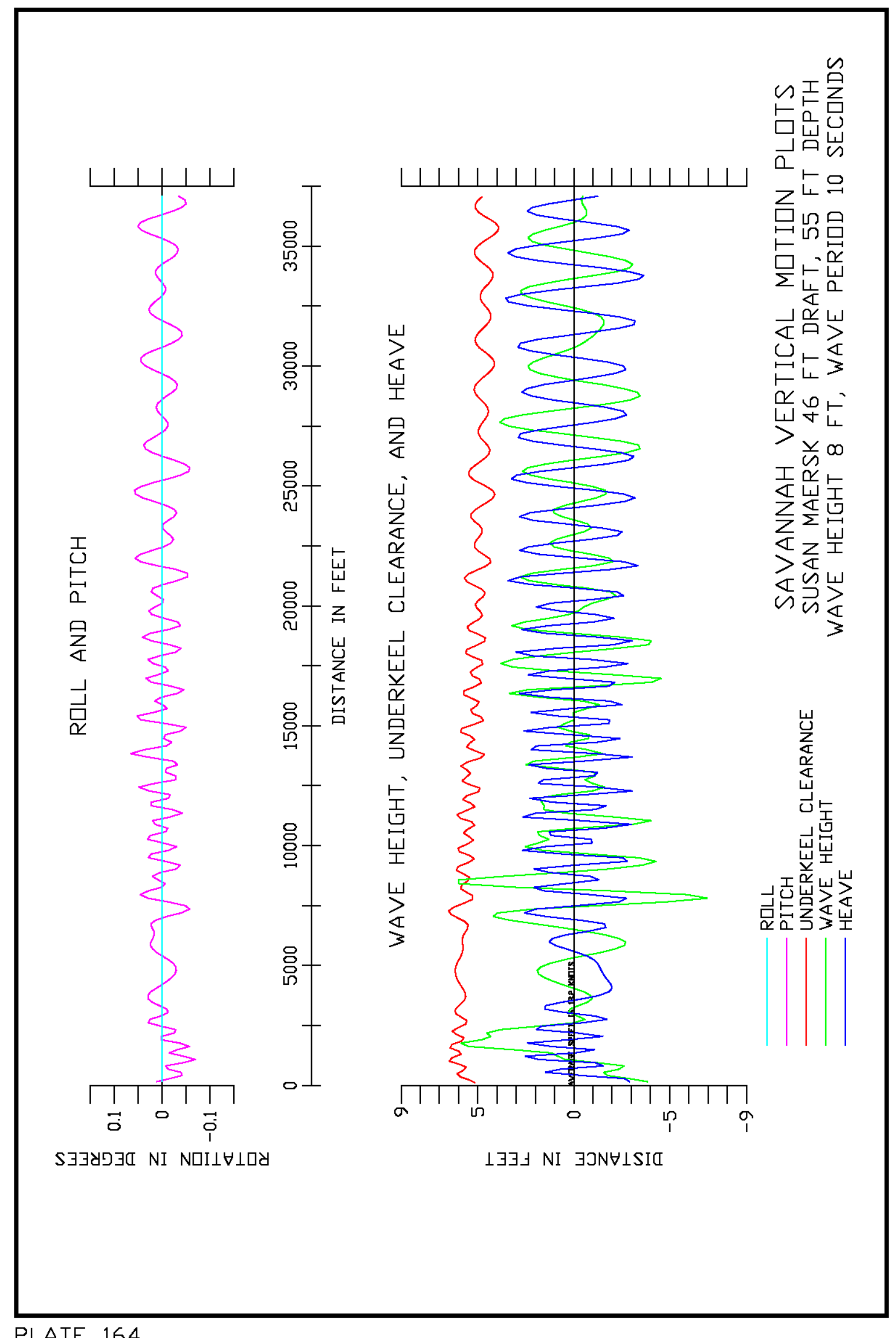

PLATE 164 


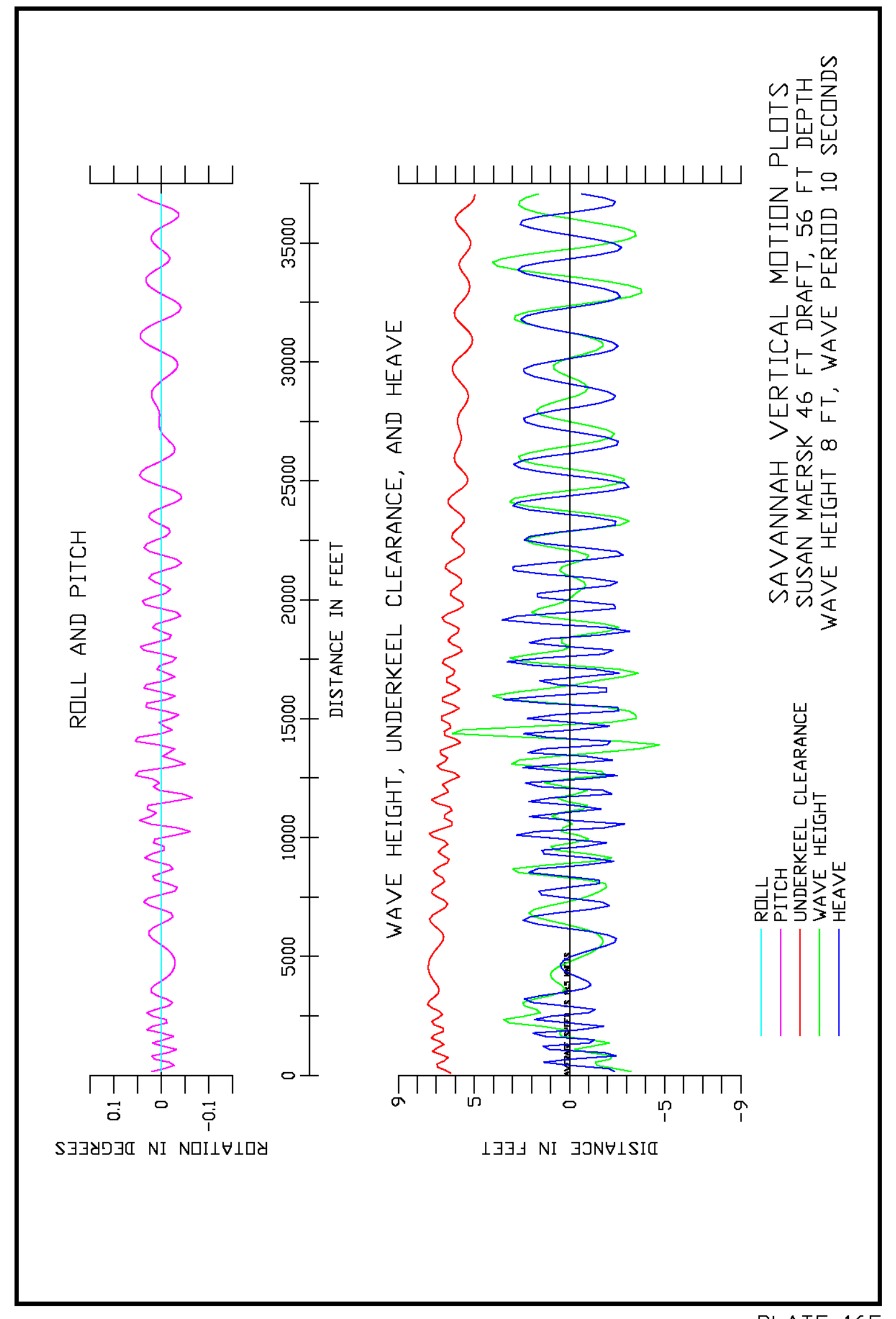




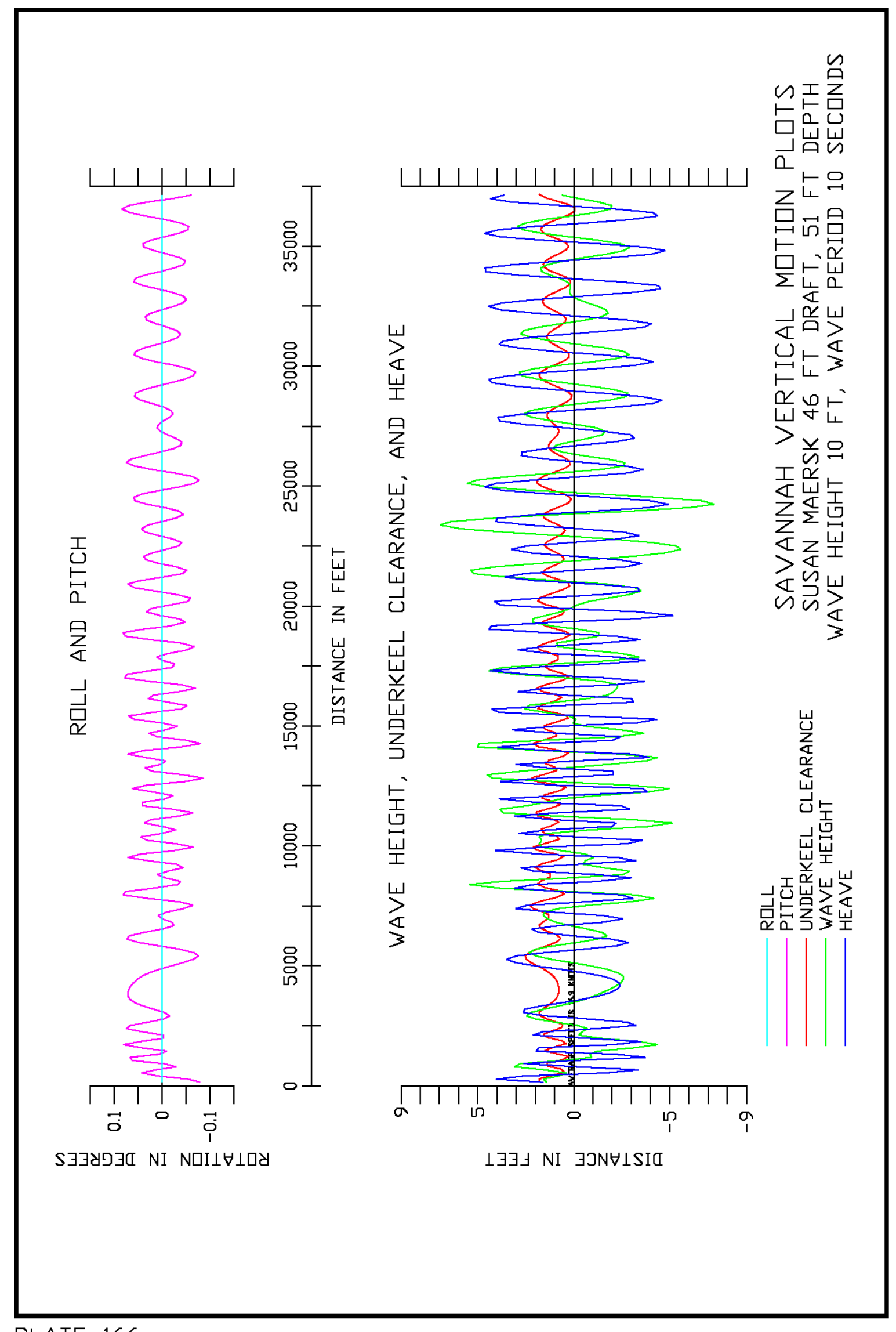

PLATE 166 


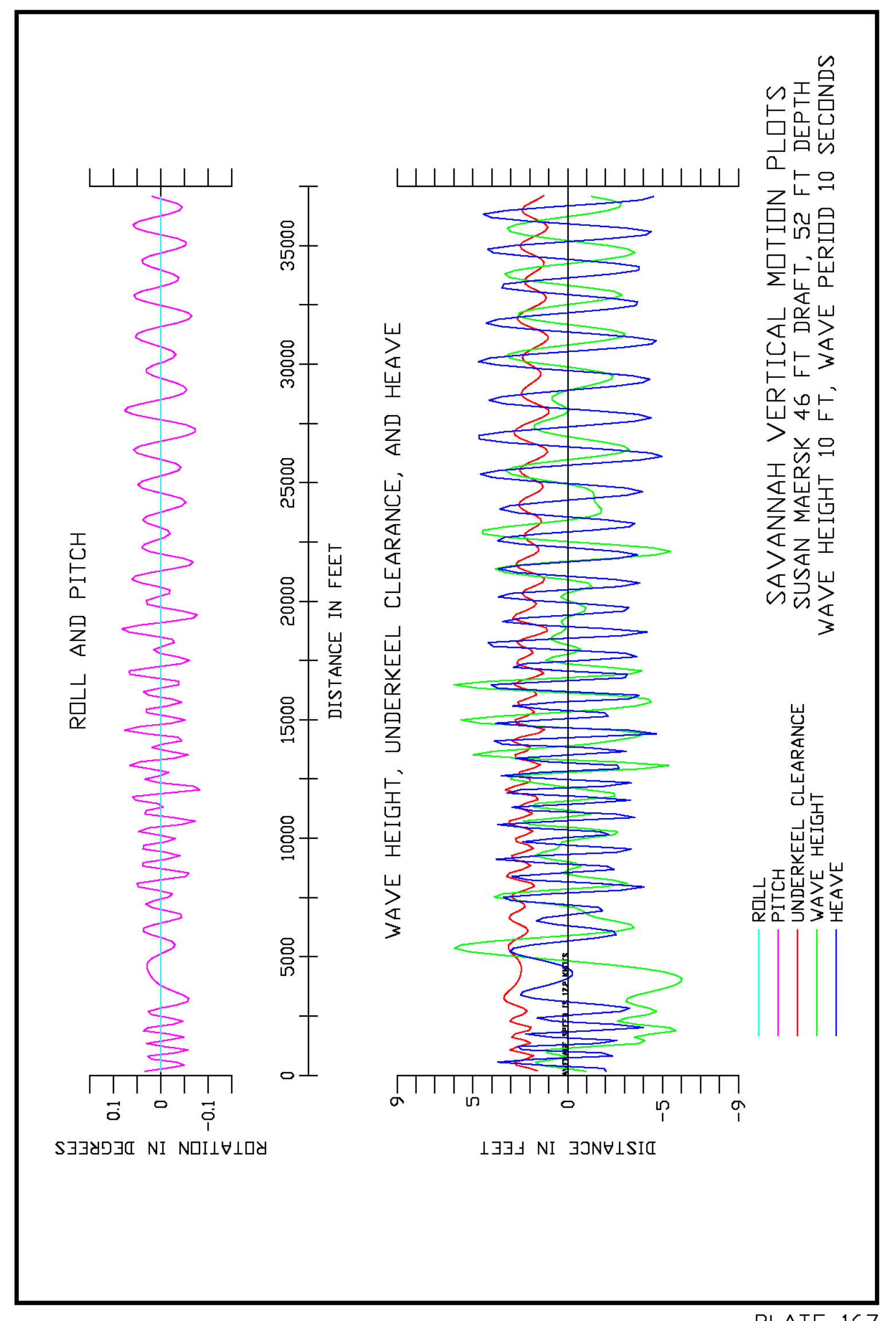




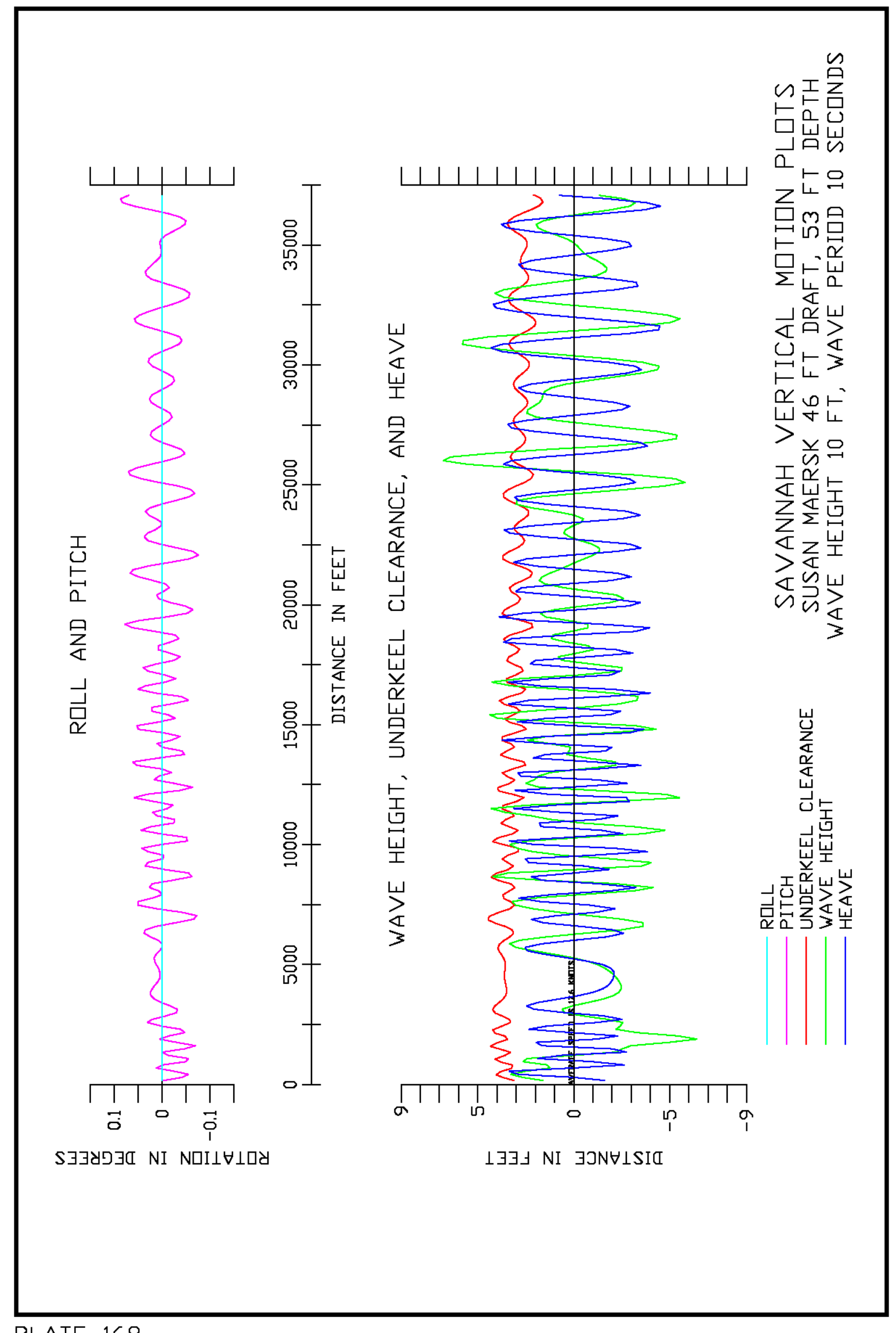

PLATE 168 


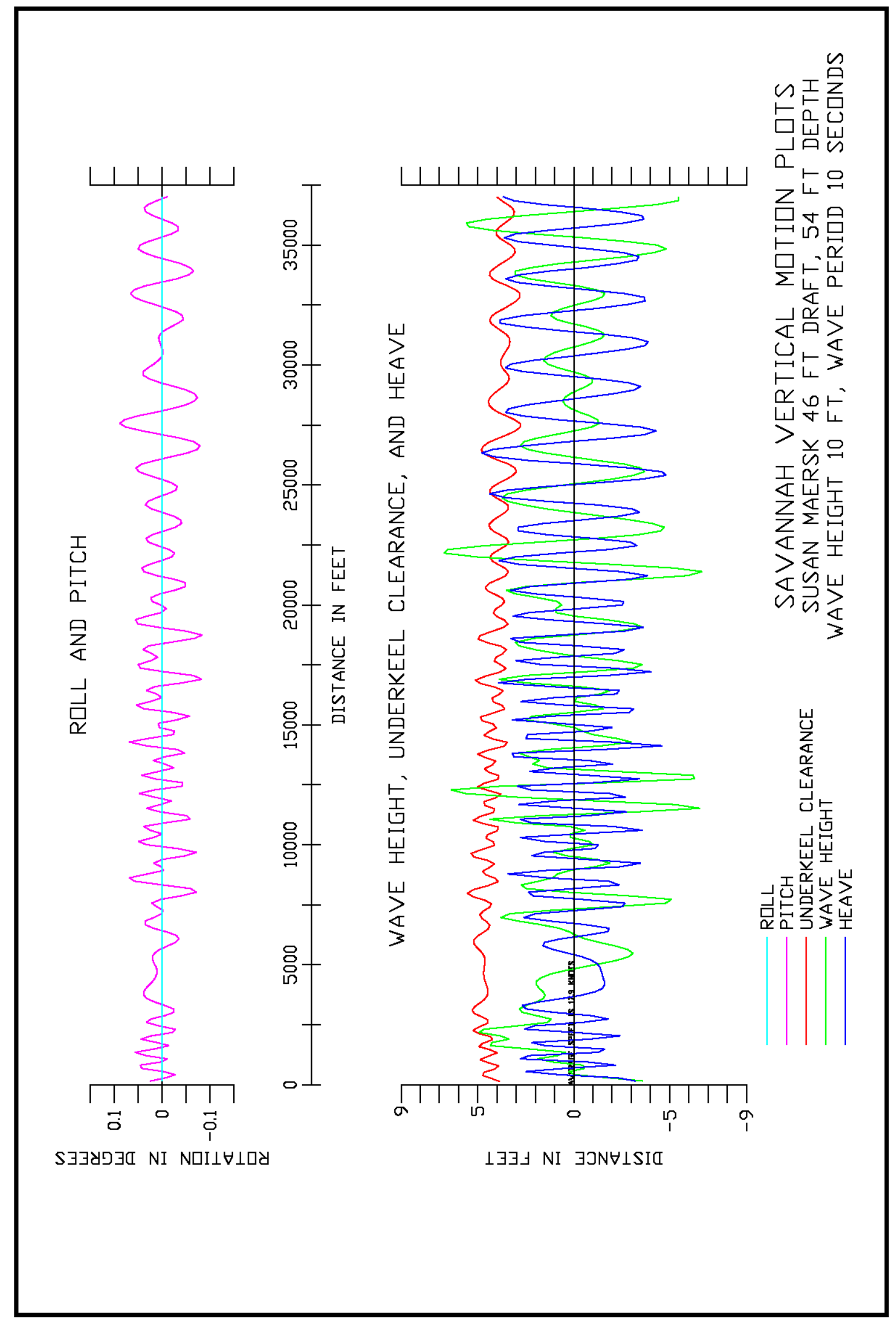




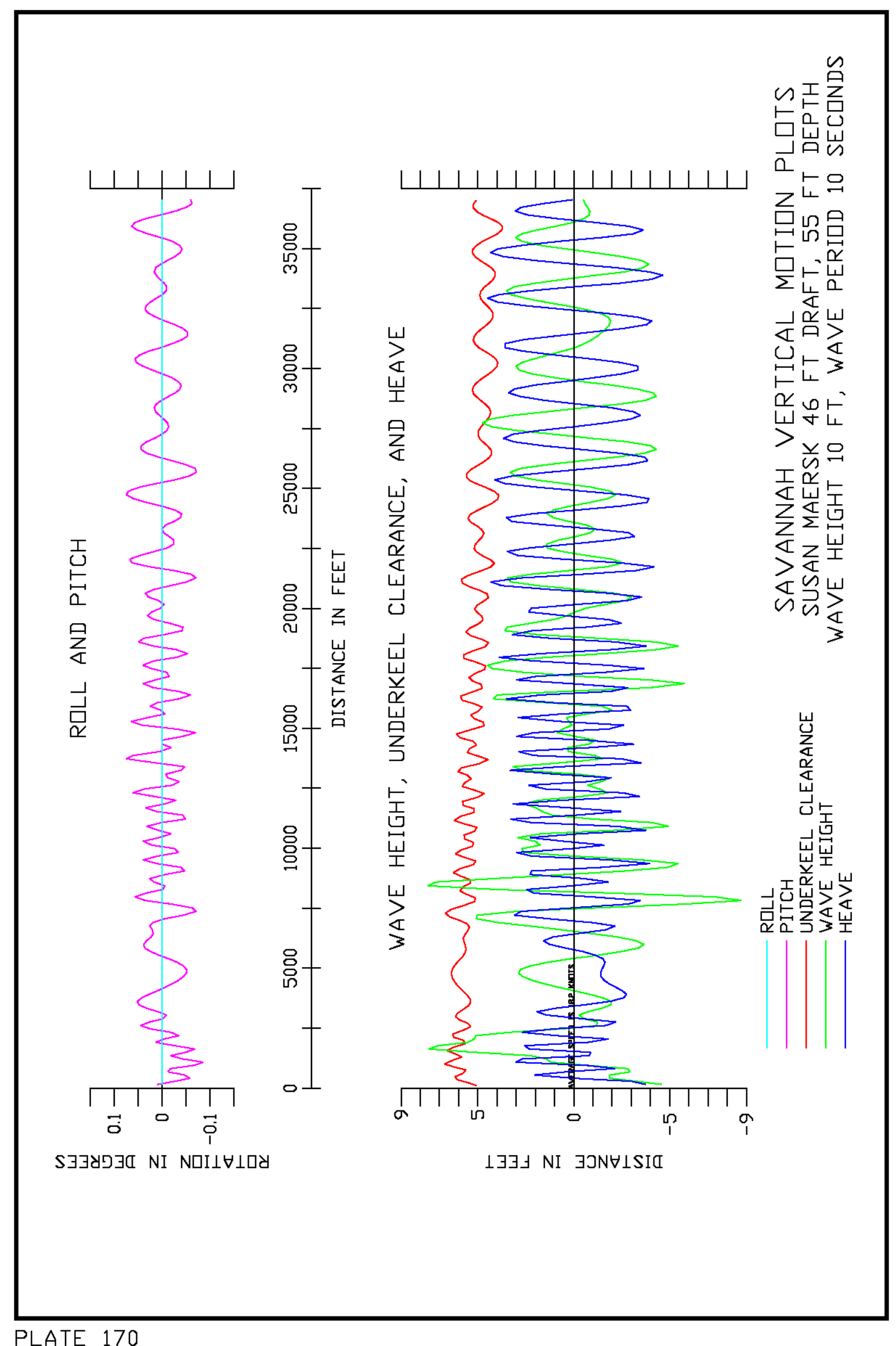




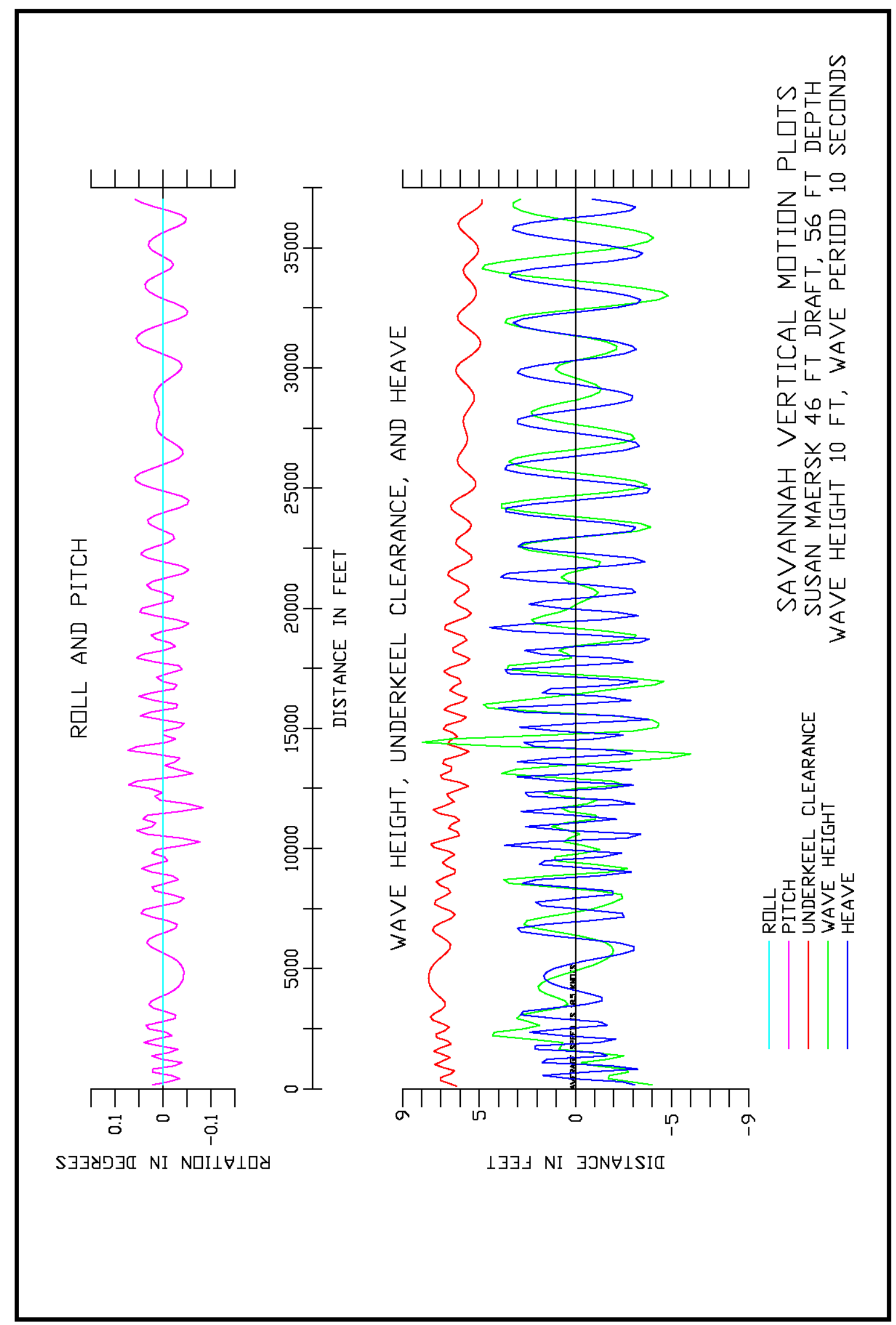




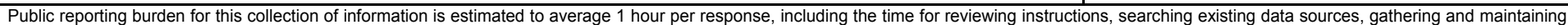

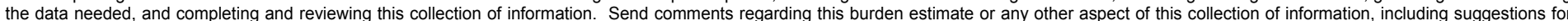

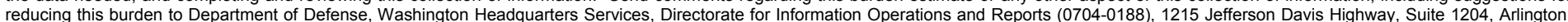

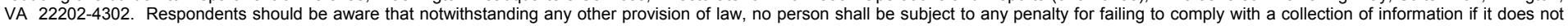
display a currently valid OMB control number. PLEASE DO NOT RETURN YOUR FORM TO THE ABOVE ADDRESS.
1. REPORT DATE (DD-MM-YYYY)
September 2004
2. REPORT TYPE
Final report

4. TITLE AND SUBTITLE

Navigation Study for Savannah Harbor Channel Improvements
3. DATES COVERED (From - To)

5a. CONTRACT NUMBER

5b. GRANT NUMBER

5c. PROGRAM ELEMENT NUMBER

5d. PROJECT NUMBER

5e. TASK NUMBER

5f. WORK UNIT NUMBER

8. PERFORMING ORGANIZATION REPORT NUMBER

ERDC/CHL TR-04-13

U.S. Army Engineer Research and Development Center

Coastal and Hydraulics Laboratory

3909 Halls Ferry Road

Vicksburg, MS 39180-6199

9. SPONSORING / MONITORING AGENCY NAME(S) AND ADDRESS(ES)

10. SPONSOR/MONITOR'S ACRONYM(S)

U.S. Army Engineer District, Savannah

PO Box 889

Savannah, GA 31402-088

11. SPONSOR/MONITOR'S REPORT NUMBER(S)

\section{DISTRIBUTION / AVAILABILITY STATEMENT}

Approved for public release; distribution is unlimited.

\section{SUPPLEMENTARY NOTES}

\section{ABSTRACT}

Savannah Harbor is located on the eastern shore of the state of Georgia. The harbor is being evaluated for deepening and widening. The purpose of the proposed improvements is to accommodate larger, deep-draft containerships to use the port. The widening is being considered to provide additional room for two-way traffic. To evaluate these improvements a real-time ship simulation study was undertaken. Simulation models were developed for both Savannah's present and future conditions. Pilots from Savannah Harbor operated the simulator as they would in real-life. Based upon these simulations, a final improved channel was developed.

\section{SUBJECT TERMS}

Savannah HARBORS

16. SECURITY CLASSIFICATION OF:

a. REPORT

UNCLASSIFIED

b. ABSTRACT
UNCLASSIFIED

Containership

Navigation study

c. THIS PAGE

UNCLASSIFIED
Simulation

17. LIMITATION OF ABSTRACT

18. NUMBER OF PAGES

222 19a. NAME OF RESPONSIBLE PERSON

19b. TELEPHONE NUMBER (include area code) 